

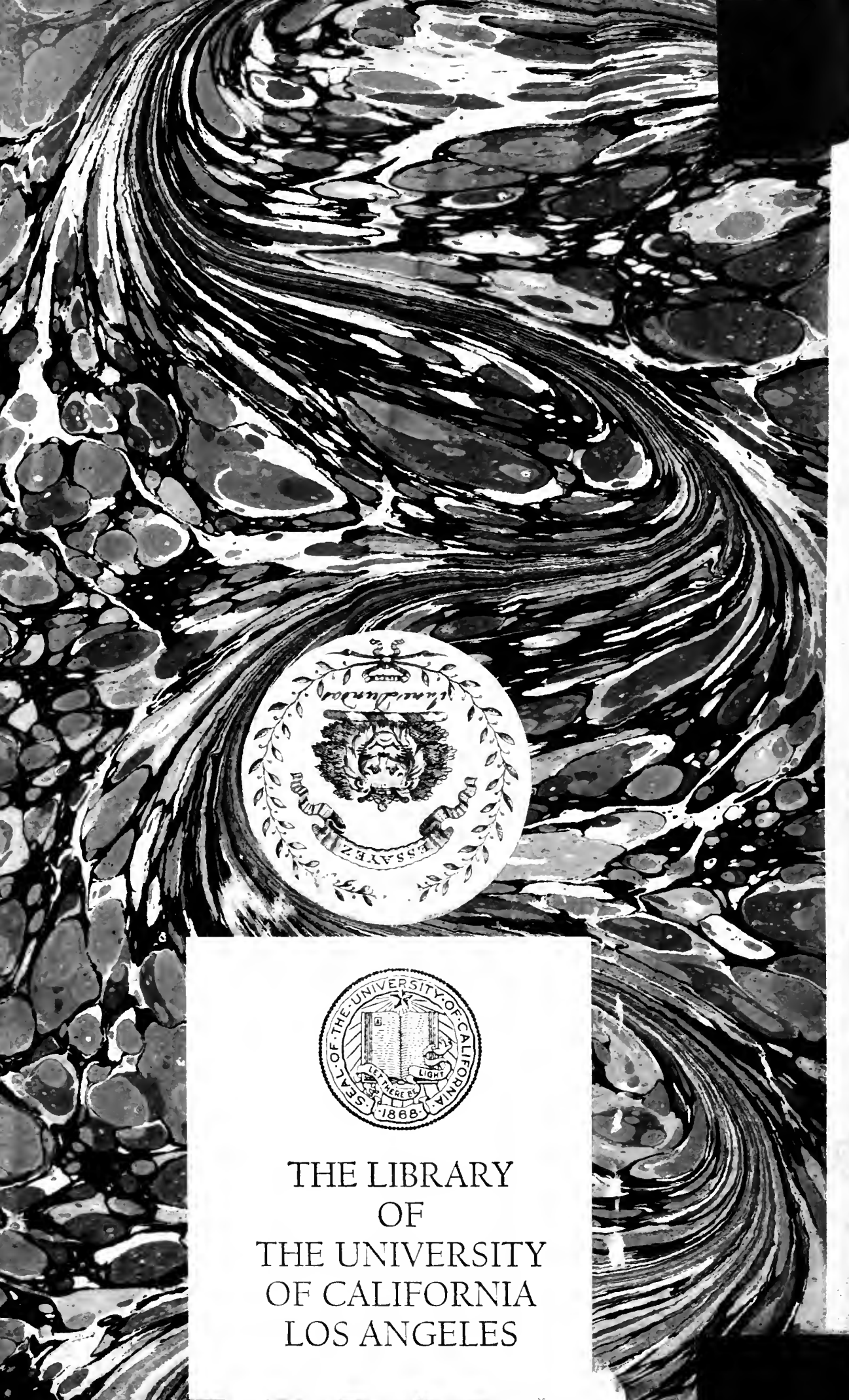




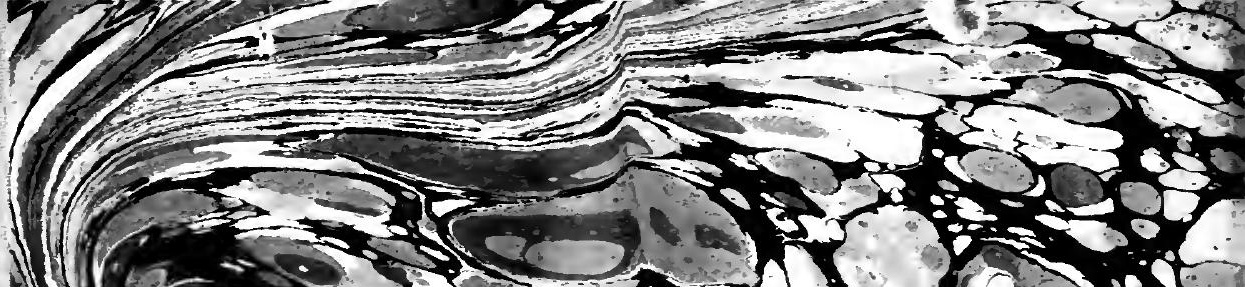

$w(x=30)$ Ho. s

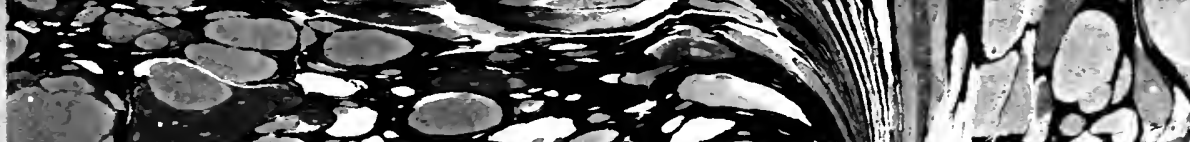

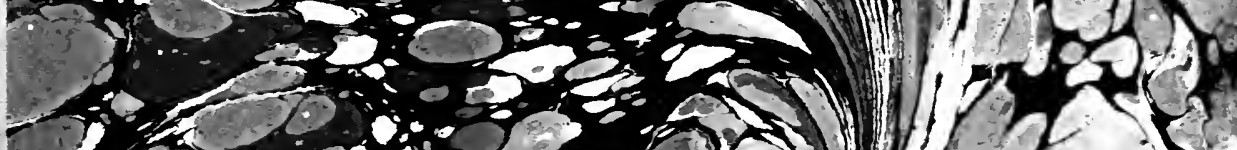
$\sqrt{(12+2)}$

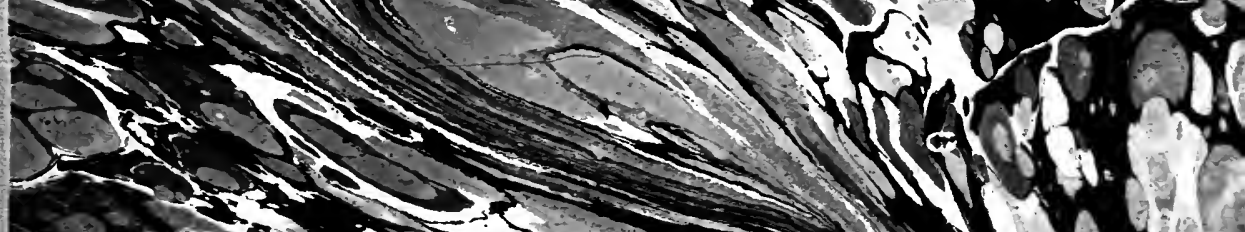

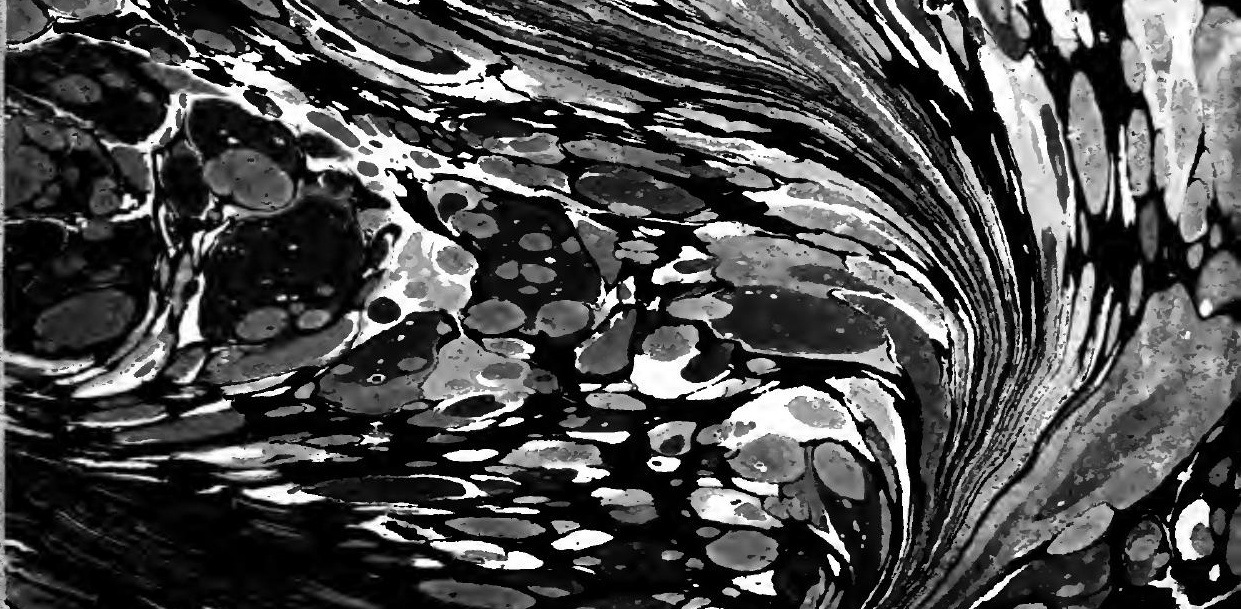





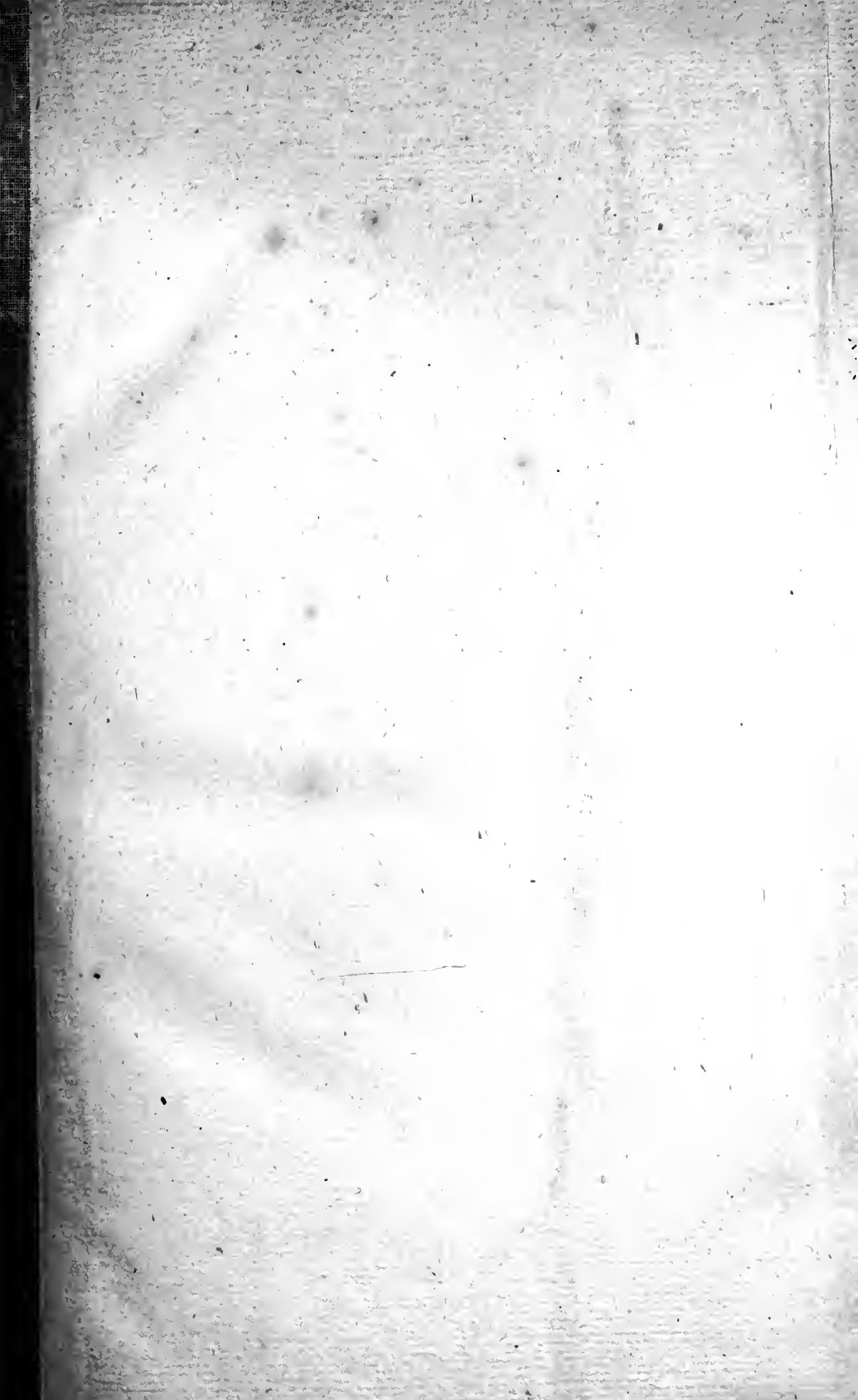




\section{Digitized by the Internet Archive in 2007 with funding from Microsoft Corporation}





\title{
Philofophical Differtations
}

\author{
ON THE
}

\section{EGYPTIANS and CHINESE.}

TRANSLATED FROM THE FRENCH

or

MR. DE PAUW,

PRIVATE READER TO FREDERIC 11. KING OF PRUSSIA,

BY CAPT. J. THOMSON.

IN TWO VOLUMES.

VOLUME THE SECOND.

$$
L \supset N D O N:
$$

PRINTED BY T. CHAPMAN, NO. IS I, FLEET-STREET;

FOR J. EDWARDS, PALL-MALL.

I79.5. 


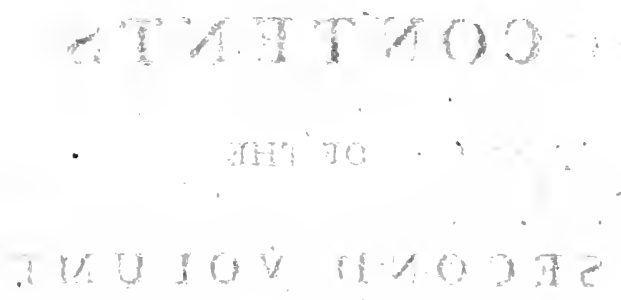

Thas orode

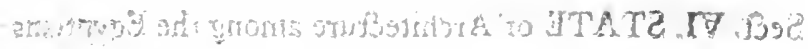
I.

tonish bre

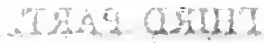

93

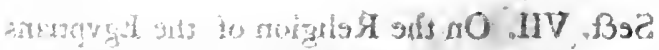

\&)

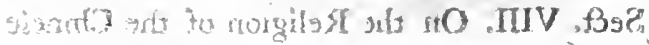

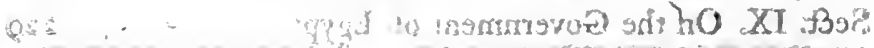
20

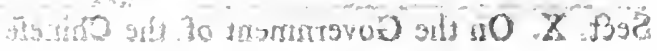




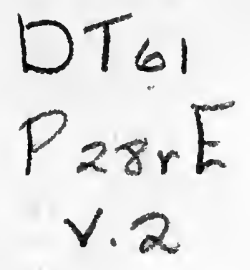

\section{C.ONTENTS}

OF THE

SECOND VOL UME.

\section{SECOND PART.}

Sect. VI. STATE of Architecture among the Egyptians and Chinefe $\quad-\quad$ - $\quad$ - $\quad$ Page I

\section{THIRD PART.}

Sect. VII. On the Religion of the Egyptians - 88

Sect. VIII. On the Religion of the Chinefe - 163

Sect. IX. On the Government of Egypt - 229

Sect. X. On the Government of the Chinefe - 290 


\section{E R R A T A.}

Page 107, line 26, for Butter, read, Buttner.

$14 \mathrm{I}$, and in other places, for Manethon, read, Manetho.

171 , and in other places, for Lon, read, Lou.

I91, - I6, for Tartan, read, Tartar.

194, - 3, for Zamoixes and Taxoras, read, Zamolxis and Toxaris.

207, - 18, for clock, read, bell.

$238,-27$, for Nomandic, read, Nomadic.

$240,-25$, for increales, read, decreafes.

$25 \mathrm{~s}$, - 14, for fudres, read, feidres.

264, - 3, after Ptolemy, read, Evax king of Arabia, Juba, $28 x,-18$, for feduce, read, fubdue. 


\section{Philofophical Differtations}

ON THE

\section{EGYPTIANS AND CHINESE.}

a

\section{SEGT. VI.}

STATE OF ARCHITECTURE AMONG THOSE PEOPIE.

\section{bas eixlon}

$T^{\mathrm{HE}}$ principal works erected by the Egyptians 1 and Chinefe are confidered here for the fole purpofe of difplaying the effential difference of genius in the two nations. We do not therefore pretend to fpeak of the principles and rules of architecture; for, however this may be the duty of the artift, it is not the object of the philofopher.

After having examined fome monuments in a general way, we propofe to defcribe more particularly the Great Wall, by which Egypt was bounded to the eaft. That no perfon may be tempted to fufpect a connexion between this rampart and that of China, we fhall point out an aftonifhing number of others, on the furface of the ancient continent. Some of thefe were fo very extenfive, that, if placed together in a ftraight line, beginning at the firft meridian, and following the direction of the equator, VOL. II. 
they would nearly have divided the whole of out hemifphere. It is very remarkable, that the inhabitants of fo many regions, on three parts of our globe, have endeavoured to fortify themfelves in this manner, chiefly againft the Tartars and Arabs: but no appearances of any fuch works have ever been difcovered in America.

Any Chinefe at this day would be much aftonifhed to fee the obelifks of Alexandria, or the Matary, and ftill more thore pyramids, ranged to the wert of the Nile, from Hauara to Gizels. So far from finding monuments of that kind in China, no perfon there ever heard them even mentioned. The emperor Kien-long, of the dynafty of Daj$d z i n$, who fat on the throne when this book was written, might perhaps have poffeffed fome paintings lefs defective than thofe feen in that country until the year one thoufand feven hundred and thirty: but not one of his houfes exhibited a fingle fine column. The princes, who preceded him fince $\Upsilon_{0}$, if ever fuch a perfon exifted, employed no other than wooden pillars, deftitute of all fixed proportions, in their palaces, pagodas, and tombs.

Thus we find the characteriftic of Chinefe architecture to be diametrically oppofite to that of the Egyptians, which tended to render indeftructible, what in the former was not only fragile, but likewife very inflammable, from the varnifh, as well as the mixture of lime, tow, and paper, with which they fill up the cavities of the wood, when any 
are found on the pillars, or the expofed parts of the entablature. The town of Nankin having once caught fire, all attempts to extinguifh it were ufelefs. Not one houfe could be faved; and three days after the conflagration, the whole diftrict did not difcover even the ruins of a habitation. The town of Thebes, on the contrary, although facked and fet on fire fo many times fince Cambyfes, prefents ftill confiderable veftiges, of which fome drawings and infcriptions have been given both by Pococke and Norden. It is believed that the great temple of Thebes may be expected to remain longer than any of the palaces erected in the prefent day; and the boatted cupola of Saint Peter's church in particular appears little calculated for durability.

Knowing the vanity of the Chinefe, and their addiction to hiftorical falfehood, we hould reduce to its juft value what they relate of thofe marvellous edifices, conftructed by their firft emperors. Some, like the pretended caftle of the emprefs $T a$-kia, never exifted; and the fabulous defcription of that building has been invented by writers, who had no idea whatever of architecture. Such muft we confider them, when they venture to affirm, that it was built of red marble inclining to a role-colour; that the light entered there, as into one of the apartments in the golden houfe of Nero; that the doors were of jafper; and that the height of the caftle was two thoufand feet. Other boalted fa. brics, like the tomb of Schi-chuan-di, were con- 
ftructed entirely of wood; and the reader may judge prefently, what grofs exaggerations have been publifhed concerning that edifice, of which not even a ruin now remains.

It is impoffible to reflect, without fmiling, on the fimplicity or folly of the Chinefe, who point out in the province of $C b e n-f i$ the fepulchre of Fo-bi. Father Du Halde obferves ferioufly, that if this monument be really authentic, it is more ancient than all thofe on our continent ${ }^{*}$. But this piece of antiquity cannot be compared to the Pike of Adam in the ifland of Ceylon, where traces are pretended to be found of Piromi the firt of mortals. Such puerile traditions, it is eafy to conceive, can only be relifhed among unenlightened nations, where hiftorical criticifm being entirely unknown, the ignorant regale each other with fables. As the lettered there know that their country was peopled by colonies from the heights of Tartary, they have fuppofed the tomb of their founder $F_{0}-b i$ to be fituated nearly in the thirtyfifth degree of north latitude, and the hundred and twenty-fecond of longitude. This correfponds with the pofition of the town of Kong-tchang, in the province of Chen-sis.

The Chinefe never knew the method of erecting ftone buildings of two or three ftories; and they are not inclined even to attempt any thing of the kind with timber. Thus all the towns of that

* Defcription of China, vol. i. 
country require three times more fpace than ex. pediency would admit; efpecially as agriculture is in full force only in their neighbourhood. Mr. Le Poivre fays, that in China the foil is fpared even in conftructing pleafure-houfes; and the great roads, he adds, are nothing more than paths*: but furely it muft be admitted, that this writer has been extravagantly enthufiaftic with regard to the Chinefe. The villa, erected by the emperor Can-bi merely through caprice, covered more furface than any of our third-rate towns; and every perfon knows, that the road leading to Pekin is one hundred and twenty feet broad. In the fouthern provinces, where neither carriages nor any beafts of burden are employed, becaufe every thing is conveyed by canals, the highways do not require to be very fpacious: but we thall fee prefently, that the interior commerce of that country is not always carried on by water.

Some travellers have fuggefted, that the Chinefe are led to prefer low houfes through fear of earth. quakes; yet fuch difafters are lefs frequent with them than in the Molucca Iflands, and Japan, where they feem to be periodical. It is however very certain, that this precaution does not enable them to refift the flighteft hocks; and whole towns are lometimes as completely deftroyed, as if they were fwept away by a whirlwind. This fpectacle prefented itfelf in the year one thoufand feven hundred and nineteen at funny, and fome other neighbour-

* Voyage d'un Philofophe. 
ing places, where not a fingle habitation was left ftanding *. In the reign of Yong-fchang, father to the prefent emperor, upwards of forty thoufand perfons were cruthed to death in Pekin, although inhabiting dwellings little better than huts. Houfes might furely be conftructed in fuch a manner as to fuffer little from earthqualses; but of this the Chinefe are altogether ignorant. They neither give folidity to the foundations, nor fufficient thicknefs to the walls, which befides are never held together by joilts or braces; and therefore it is not aftonifing, that they fhould be eafily fhattered to pieces. At one time, the fteeple of Nankin tumbled down under the weight of its bell.

Architecture in China, like all the other arts, is reduced to practice, inftead of rules. The trunk of a tree, called Nan-mou, and not the. palm, has ferved there as the model for the columns; and although its fpecies is not exactly known, it appears to belong to the clafs of larches, or firs. When the idea of the pillar was acquired, it might be fuppofed, that the proportions likewife would have been afcertained; and yet they were never reduced to fixed principles. Mr. Chambers, who meafured fome parts of a pagoda at Canton, fays that the height of the pillars was equal to from eight to twelve times their diameter $\dagger$; but this is not gene-

* Bell of Antermony, vol. i.

rally

+ It is even poffible that Mr. Chambers had taken the dimenfions of a pagoda faid to have been formerly a church belonging 
rally the cafe. They are in reality efteemed only for their great fize, when confifting of one fingle piece; and this is confidered as a fpecies of luxury and magnificence. As trees with all the neceffary qualities cannot eafily be found, the private houfes are fupported by trunks, feldom exceeding thirteen or fourteen feet in height, from the root to that part where the diminution becomes very apparent. The Nan-mou, like firs in general, grows very lofty while young, and requires many years to attain much circumference. Thus the difficulty of procuring timber of fuch dimenfions muft have determined the Chinefe to prefer this tree to all others. In a pagoda near Nankin, fome are now feen upwards of five feet in diameter: but thofe of the new palace at Pekin, rebuilt fince the fire in the reign of Can-bi, do not exceed two feet and a half.

It is furprifing that the Chinefe, with fuch ideas, fhould never have attempted to work in ftone, efpecially as their whole country abounds with quarries. Their edifices, deftitute of fymmetry in the whole, or proportion among the component parts, are inferior even to thofe of the Perfians and Turks. They extend the frieze enormoully, for the fole purpofe of difplaying a profufion of ornaments, too whimfical to be defcribed. Among the Egyptians, that part feems to have been defined chiefly to contain reprefentations of the facred

to the Jefuits. He was befides ignorant of a.fact which thall be related hereafter. 
animals. The Greeks therefore called it the Zophorus, and we fhould have adopted that word, rather than the term frieze, which is altogether barbarous.

No particular place in the pagodas and palaces feems to have been allotted for the emblem of the dragon. It is feen every-where, even on the fummit and angles of the roof, producing the moft difagreeable effect poflible. The paffion of the Chinefe is unaccountable in multiplying copies of this hideous monfter, which refembles fometimes a lizard of Iguan, and frequently a winged toad, with the tail of an elephant. It might have been preferved on banners and liveries, as the principal piece of ancient arms; and this would only be conformable to the immutability of cuftoms in the Eaft. But the ufe made of it in architecture is not more reafonable than the invention of thofe French artifts, who fculptured heads of cocks, and flower-de-luces, on chapiters of the Corinthian order. A more frigid allufion could not pofibly be made to the name and emblem of their nation.

The Chinefe conftruct their edifices in fuch a manner, that the principal walls fupport nothing, while the top refts immediately on wooden pillars. This defective mode was never adopted; as fom $_{e}$ have believed, to prevent the progrefs of fire; and it has forced them to invent double roofs, extending one below the other; becaufe a feparate thed is neceffary to protect the walls. Solidity is every- 
where neglected, and without it architecture has no real beauty. The houfes, built along the river Canton, have indeed fome works to raife them above the water; but in the interior provinces whole towns are erected without any foundation. In fome of their towers, the firt layer of bricks is not twenty-four inches below ground; and confequently, as Father Trigault fays, they feldom remain ftanding during a fingle century*. We muft however except the Van-ly-czin, or Great Wall, which was conftructed by feveral kings to. tally independent of the Chinefe emperors. Their intereft led them to make that work capable of refifting the efforts of an enemy; otherwife the whole undertaking would have been abfurd. Yet the parts, which do not reft on the folid rock, or are neglected for a fhort time, foon fall into ruins. The thicknefs of the pillars, ufed by the Chinefe through mere oftentation, does not contribute to the folidity of the building; becaufe their pedeftals are not fecured in the earth. The bafis is nothing more than a fquare ftone, laid on the furface of the ground, with a llight excavation to contain the lower end of the column; while the orher is united, without any fwelling, to what they may pretend to call the architrave. No chapiter of any kind is ever employed by the Chinefe ; and this circumftance, as well as a thoufand others, proves how much their manner of building differs

* Ita raro unius Saculi atatem ferunt. Exped. apud Sin. lib. I. 
from that of the Egyptians, whofe imagination was greatly exercifed in embellifing that part of their columns. They did not confine themfelves entirely to the form defcribed by Athenæus*; for nine or ten different kinds have been difcovered in the ruins of Thebais and the Delta. Finally, in a Chinefe pagoda we fee neither ranks of fphinxes, inclining walls, flat roofs, obelifks, crypts, fubterraneous vaults, nor any thing refembling an Egyptian temple.

Many miftakes feem to have been propagated with regard to the model adopted for the firft Egyptian houfes; but the Chinefe evidently imitated the form of their tents. From all that we can learn of their primitive ftate, they were originally Nomades, or Scenites, like all the Tartars; and confequently encamped with their flocks, previous to their fettlement in towns. This, without doubt, gave rife to the fingular conftruction of their prefent dwellings, where the roofs remain after the walls are thrown down, becaufe they have no connexion with the timber-work. An inclofure of mafonry had been made in this manner round the tents, to contain the cattle; and fuch was certainly the firft ftep, leading from a paftoral and wandering life towards fixed habitations. Nothing in fact can have more refemblance to an encampment than a Chinefe town, which, at fome diftance, is moftly concealed by the ramparts, be-

- Lib. r. cap. 6. 
caufe the houfes are all of one fingle ftory. Thus Mr. Bougainville, when fpeaking of an eftablifhment near Batavia, calls it the Cbinefe Camp*.

An' hiftorian, or rather a fabulift of China, called the Lo-pi, fays that the firft habitations of his country refembled the nefts of birds. But this is an Oriental figure, and muft not confequently be underftood in a literal fenfe. It is not probable, that the Chinefe ever lived among the boughs of trees, like thofe favages of South America, who through ftupidity and lazinefs did not clear the courfe of the rivers, which in fummer overflowed their banks between the tropics. Thus their only refuge for a part of the year was on the tops of trees, devouring, like monkeys and marmolets, the fruit they found on the branches. By nefts of birds, the Lo-pi probably intended to fignify low round tents, made like bee-hives, and ufed by the Tartars, who frequent Chamo and other fandy deferts. It would be impoffible there to ufe wooden pins for pitching tents, like thofe now employed by the Chinefe foldiers, which are almoft exactly fimilar to thofe of our own armies $\dagger$.

It is difficult indeed to conceive, how the Abbe Barthelemy could affirm, that the edifices on the celebrated Paleftrina Mofaic refembled Chinefe houfes. That learned man muft have experienced fingular illufions in examining that monument;

* Voyage round the World, vol. ii.

+ Military Art of the Chinefe. 
and one example will be fufficient to give an idea of all the reft. He affures us that, in the barks on the Nile, fome perfons are feen with round and pointed bonnets, like thofe worn in China at this day; and thence he concludes, that the Chinefe were originally Egyptians*. But how could he not have perceived that this drefs was not ufed in China before the year one thoufand fix hundred and forty-four? It is really the Tartar hat, with which the people were forced to cover themfelves, when they received orders from their conquerors to cut off their long hair. Thus the pretended refemblances, imagined without reflection or refearches, between the Egyptians and Chinefe, vanifh like chimeras. We have feen nearly all the engraved copies extant of the Paleftrina Mofaic; and particularly that inferted by the Abbe Barthelemy himfelf in the Memoirs of the Academy of Infcriptions. Yet in none of thefe does it appear, that the barks ufed on the Nile, fo much talked of by this author, have any more conformity with the boats of China than with the gondolas of Venice. The veffels of all nations, from the canoes of the Hurons to the galleys of the Mediterranean, feem to have had nearly the fame primitive form; and we are juftified in afferting, that fuch circumftances cannot afcertain the hiftory of a

* Explanation of the Paleftrina Mofaic.-The ancient Egyptians cut off their hair: the Chinefe, on the contrary, difcovered the greateft obftinacy in preferving it, as we have feen on the conqueft of the Tartars. 
colony fent from Africa to the extremity of Afia.

Although the Chinefe are long acquainted with the art of making arches, they have feldom practifed it in the conftruction of their bridges. That in the province of Fun-nan confifts of nothing more than piles, placed at certain diftances, and joined by iron chains, along which the traveller paffes with terror. Men of any dexterity would furely never have executed a work of that nature. Inde. pendently of all other inconveniencies and dangers, the ruft, occafioned by fogs from the river, mult affect the-metal, and make it liable to give way when leaft expected. Father Parenin, in his letter, places this pretended iron bridge in competition with all the great edifices of Egypt; and fuch partiality in favor of the Chinefe is fo remarkable among all the writers of his order, that we read their accounts with continual diffidence. Many other bridges are feen in China, where, inftead of arches, flat ftones are placed on pofts, erected at fmall diftances. The great number of thefe fupports has been confidered by ignorant travellers as highly ornamental; but the precaution is abfolutely neceffary; otherwife the crofs ftones, whatever might be their thicknefs, would foon break in the middle.

With regard to the famous flying bridge, fo much celebrated in Europe, and fo often reprefented by engravings, we are under the neceffity of declaring, that nothing, fuch as it is defcribed, 
ever exifted. The author of the Continuation of Rollin's Hiftory feems to infinuate, that Father Kircher took the liberty of inventing this flying bridge, in a work publihed at Amfterdam, under the title of Cbina illuftrated. This Father Kircher, who is accufed of fo many things, had certainly very ftrange vifions, and much effrontery in publifhing then ; but here we muft do him the juftice to obferve, that he only fpoke after the Atlas of Martini, as did alfo the anonymous compiler of the Wonders of Art and Nature*. The inventor of the flying bridge, however, wanted common fenfe; and it is not extraordinary that an able French architect, named Boffrand, after examining the dimenfions, declared them to be chimerical in all their points. It is eafy indeed to perceive at once, that no fuch bridge could be erected by means of the Roman arch, or even of the Gothic, which is commonly employed in China. What has given rife among Europeans to fo many abfurd fables, but too grateful to the vanity of the Chinefe, is in reality the production of a torrent. It opened a paffage under rocks, which were probably fupported by a layer of earth, and in that manner produced a phenomenon not unexampled among the Alps. All the bridges conftructed by the Chinefe are exceedingly whimfical; and even when compofed of arches, they want ftrength, as Father Du Halde obferves, to fupport loaded carriages: but as they form a very acute angle at the fummit, no danger

- Artificia Hominum et Miranda Naturæ in Sina. 
is to be apprehended from any thing of that kind; for even travellers have to pafs them by ftairs. When the Chinefe are afked why fo much elevation is given to the centre arch; they fay it muft be fo, in order that the barks may pafs without interruption. Inftead of incurring fo much danger, it would furely be better to make the veffels lower their mafts, which is no difficult operation on fmall rivers.

An obfervation of the utmoft confequence, and fufficient to undeceive us for ever with regard to what the Chinefe hiftorians relate of the flourifhing ftate of their country under the ancient emperors, concerns the $1 u$-ho or Royal Canal. That work, truly worthy of admiration, has been executed by very fkilful artifts, who underfood levelling perfectly; and the mechanifm of the locks they conftructed is as fimple as the effect is aftonifhing. Almoft the whole interior commerce of the country is carried on by this navigation, which opens a communication with the fouthern provinces and thofe of Pe-tcheli and Kian-nan, without any of the dangers attending fea voyages. Thus it is impoffible that, previous to its being opened, the inland trade could ever have had great activity. Readers, who poffefs any thare of penetration, will eafily conceive what hould be inferred here, and therefore we fhall not infift further on this point. But it muft not be imagined, that the Royal Canal was made by the Chinefe; for their architects were incapable of undertaking any thing of the kind. That aftonifhing 
aftonifhing bed, by which the rivers flow into the lakes, and the lakes into the rivers, without their being liable either to dry up or overflow, was dug by the Mogul Tartars. It extends for more than fix hundred leagues; and affords a navigation from one extremity of the empire to the other.

The conqueror Koublai, whofe name can never perifh, was a well-informed prince, and a lover of the arts. He invited into China many learned Perfians, Arabs, and Lamas, particularly aftronomers, geographers, and architects. The firft were employed in compofing almanacs; the fecond made obfervations as far north as the fifty-fifth degree, and fouth to the fixteenth, taking the altitude of different parts of China, Corea, Tartary, and Tonquin: the third clafs began to make the great canal, about the year one thoufand two hundred and eighty of our era ; and fince that epoch, the-appearance of China has changed entirely. The fea formerly fwallowed up three-fourths of the veffels which attempted to pars Li-ampo, in their paffage into the gulph of Nankin. At length the Moguls, hocked at fo many hipwrecks, took compaffion on the Chinefe, who navigated fo badly on the ocean, and had not fufficient induftry to open a way acrofs the continent. Not a fingle veffel is now loft in paffing the locks, and they continue to be kept in perfect repair by the vigilance of the Mandhui Tartars. Had thefe conquerors not appeared, it is probable that the Chinefe would have fuffered this work, already much decayed in one 
thoufand fix hundred and forty, to fall entirely into ruins; and then the country muft have been reduced to its former miferable ftate.

All the trenches for watering the fields, and the numerous crofs canals which communicate with the $r_{u-b o}$, were-likewife formed by the care of KoublaiKan; who befides opened all fouthern China to foreign traders. It was in his reign that fhips were feen there for the firft time from Malabar, Sumatra, and Ceylon. By thefe means the provinces began to breathe, after having becn exhaufted by the rapacioufnefs of the Chinefe officers, who required as many contributions in their own country, as if they had entered there as conquerors; and; pillaged in turn by victorious enemies, they were loft to every fenfe of fhame or honor. Koublai, to prevent fuch diforders, augmented the pay of the army, which under the ancient government had been badly maintained, and did not indeed deferve better treatment. After fuch facts, the Chinefe muft be confidered as guilty of the bafeft ingram titude, when they endeavour to blacken the memory of that prince. They blame him for having confided in men from the weft, although thefe were the geographers and architects employed in conftructing works; which would do honor to the greateft monarchs. Hie was reproached befides with loving women, and being attached to the DalaiLama. Yet all the emperors of China, prior to his arrival, had feraglios containing three or four hundred concubines, guarded by twelve or thira 
teen thoufand eunuchs. The Dalai-Lama was the legitimate pontiff of the religion profeffed by Koublai-Kan; and in the midlt of his glory, and through a long courfe of profperity, he never forgot that the conqueror and the humbleft fave were equally in the hands of the Ommipotent. But although firmly devoted to the worlhip of his anceftors, he never perfecuted the conquered for any of their filly opinions; and his conduct in this point was very different from that of Alexander. The Perfian Magi were continually tormented by the Macedonian, and they could not entirely preferve the facted books of Zond from his fanaticintr.

The Arabs, who travelled in China in the eighth century, found that country fubjected to eunuchs, and peopled in fome places by anthropophagi * Various conjectures have been made on this report; and many tend to difpute its authenticity. Yet the government of that class of men is an undoubted fact; and the appearance of China has certainly undergone a great change fince that period. The revolution in commerce and agriculture did not take place until the reign of Koublai-Kan, the founder of the twenticth dynafy. Then, likewife, whatever Tather Goubil may fay to the contrary, aftronomy was firf introduced there: but the knowledge, brought thither by the Arabs, Perfians, and learned men of Balk and Samarcand who followed the Moguls, was loft a fecond time * Ancient Relation of India and China, publifled by the Abbé Renaudot. 
at the extinction of the twentieth dynaty: Of this we have a proof in an edict of the firf Mandhui emperor; publifhed in one thoufand fix hundrod and fifty: it fets forth, that ever fince the expulfion of the Moguls, the Chinefe were incapable of making an exact almanac; that their errors, augmenting every year, became a difgrace to the conquerors, as well as to the people of the. country; and therefore it was neceffary to abandon the pretended tribunal of mathematics to Europeans. They are ftill in poffention of that office; and in cale of their being removed, the firn calendar compoied by the Chinefe would be grofsly erroneous; for as long as they preferve their language and manner of wring, if is impolible for them to make much progrefs in any of the fciences. Some hiftorians with to perfuade us that obfervatories are now feen in China, which were built three thoufand years ago, although no monument, we may aver, in that country can reafonably be fuppofed to approach fo great antiquity. The only building of the kind, known to us, is at Pckin, and that town was founded.by Koublai-Kan in the year one thoufand two hindred and fixty-feven *. The ob. fervatory mult therefore have been erected pofterior to the conqueit of the Mogul Tartars; who, as we have obferved, changed the face of the whole empire. With regärd to fome inftruments, difcovered on a mountain near Nankin, they were cer-

* The part of Pekin called the Clinefs. Tusen was rot built until the year 1644 . 
tainly made in the year one thoufand three hundred and forty-nine.

The following obfervation muft appear decifive on this point : the latitude of Pekin is 39 degrees, 55 minutes, and I 5 feconds, which is rather more than in the map of $D^{\prime}$ Anville; that of Nankin is 32 degrees, 4 minutes, and 3 feconds. Yet the dials and other inftruments, employed at thofe two places, were made to anfwer fomewhat beyond the thirty-fixth degree, and confequently all the obfervations taken by the Chinefe were erroneous.

Having reflected on this fingularity, which no perfon had ever explained, it appeared to me at laft, that the inftruments ufed by the Chinefe muft have been copied from thofe adapted to the fchools of Balk. That town is fituated about thirty minutes beyond the thirty-fixth degree*, in the ancient Bactriana, where the fciences began to be cultivated by the Greeks, who having obtained the government of that country under the fucceffors of Alexander, rendered themfelves independent, and formed an empire extending as far as India t.

Inftruments, calculated for the latitude of Balk, muft therefore have been brought to China in the time of the Moguls; and fuch is the origin of the moft abfurd error ever adopted in any country. At

* In D'Anville's great map of Afia, Balk is fomewhat more to the north : but an Arab named Eben-Said has placed it in 35 degrees and 54 minutes.

+ Bayer, Hiftoria Regni Græcorum Bactriani ; ánd a memoir of Mr. de Guignes. 
the arrival of the Jefuits, the Chinefe maintained that all the towns of China were fituated in the thirty-fixth degree. This is acknowledged even by Father Kircher, who adds, that they had no idea whatever of longitude*. Thus they muft be allowed to have been as ignorant of the hiftory of the earth, which they fuppofed to be fquare, as of the Aky, where they believed the planets to be equally elevated with the ftars.

It muft be confeffed that the Romans, for fome time, did really ufe a folar dial, formed for the latitude of Catania, without perceiving their error. Rome however had not then been built more than three hundred and four years; and that term is very infufficient for any nation to acquire even the firft principles of aftronomy. But when the Chinefe fell into fuch abfurdities, they had already exifted as a nation, according to their authentic annals, during more than three thoufand years.

As to the obfervatory of the province of Ho-nan, it deferves to be placed, with the fabulous palace of the emprefs Ta-kia, among the edifices which never exifted. Father Martini is the only perfon who afferts that the town of Teng-fong-bien contains a prodigious rule of brafs, placed perpendicularly on a plate of the fame metal; and he then proceeds to fpeak of a tower, built near three thoufand years ago, where the pretended Chinefe aftronomer T⿱宀 cheouKong obferved the movements of the heavenly bodies. This huge rule and plate of brafs have

* China Illuftrata, p. Ioz. in folio.

c 3

been 
been changed by Father du Halde into a fimple in: ftrument, and Mr. Boyfen, when fpeaking of the town of Tens-fong-bien, mentions nothing more than the tower. Thus we find the obfervatory difappears entirely, except a few heaps of ftones, which are fuppofed to have belonged to fomething of the kind : but if the learned of Europe had an opportunity of vifuing the fpot, they night be at a lots to find thofe ruins, as well as the extracordinary things introduced by Father Martini to embellin his book. The whole work, indeed, is fo mamefully incorrect, that it might with more propriety be called a collection of common reports than an Atlas.

If China contained any monuments of great antiquity, we might expect to find them among the tombs of the emperors. But being all formed of wood, they have difappeared entirely, either from. the effects of time, humidity ${ }_{2}$ or fire. It is cuftomary to have tlem furrounded with thick forens of cyprefies, or thofe firs called by M.Ir. Ofbeck abies Sincnfis, which are devoted to the flames by the people, whencver they becone difcontented with the reigning dynafy. Befides, when the robbers grow powerful, and fpread themfelves over the cantons, where any imperial tombs are found, they pillage them fo completely, that even the roofs are not left ftanding. The hiftory of China frequently mentions fuch difafters, which cannot be avoided, becaure the Miao, if. formed in the midlt of towns would foon transform then into burying-grounds, The princes, the governors, and the great manda- 
rines, muft have their places of fepulture haded with trees, planted in quincunx to a very great diftance, and much foil fit for culture has been wafted, to gratify this obfinacy.

An Egyptian. law, preferved by Plato, declares that no. perfon fhould be buried on any fpot capable of producing a tree. Wc know to a certainty, that the Pharaohs, even to the dynaty of the Saitæ, conformed themfelves to this wife regulation; for not even a fhrub could be planted either in the environs of the pyramids, or around the royal fepulchres of Thebes. But this is not the only circumftance, in which the two nations differ with regard to their funeral ceremonies; for in general they are roid of every kind of analogy.

However defirous we may be of knowirio the fpe. cies of architecture, and tafte of ornaments, exhibited on the tombs of the Chinefe emperors, yet unfortunately no fuch information is to be expected from the accounts of the Jefuits. All they have. written on that fubject can be confidered only as a collection of fictions; and to prove this, we fhall, however unwillingly, infert here the defcription given by Father du. Halde of the pretended tomb of Scbi-cluuan-di:

This prince, fays he, chofe for bis fepulcbre the mount LY. He caufed it to be bollowed out, as one may' fay, even to the contre of the carth. Above, be crected a manfolaun, which refembled a mountain, five buindred feet bigh, and at leaft balf a league in circuniference. In the middle was a rich coffin; and around

$$
\text { c } 4
$$


it were lamps and flambeaux, kept burning with buman fat. Witbin the tomb, on one fide, appeared a vaft lake of quickflver, on which were feen many birds of gold and filver: wobile the oiber fide exbibited a complete afortment of furniture and arms. Thoufands of precious jewels were frewed bere and there. It bad coft not only immenfe fums of money, but likewife the lives of many perfons; for befictes the forvants of the palace, who fuffered death, upwards of ten thoufand worknen were buried there alive ..... All at once the people, who could no longer fupport the yoke, flew to arms. Hang-fi demolifbed the vaft inclofures. The coffin fill remained; until a Jepherd, it is faid, when looking for a fray Jheep in the mid/t of the ruins, let fall fome jparks of fire wobich confumed them altogether*.

Such a defcription does not deferve to be feverely criticifed, becaufe whoever reads it with the fmalleft reflection muft be fufficiently difgufted. Thofe lamps with human greafe, and birds of gold fwimming on mercury within a tomb, are fuch childifh prodigies, that our moft wretched writers of romance would fcarcely infert them among fairy-tales. Father du Halde might furely have exaggerated, in a far more ingenious manner, concerning China.

Through this cloud of fables, however, we difcover two certain facts: in the firft place, the tomb muft have been wood, from its being deftroyed by. fire; and we perceive likewife that unfortunate wretches were flaughtered on fuch occafions.

* Defcription of China, vol. ii. 
The emperor Scbi-cbuan-di defcended from 2 Chinefe family of $\tau_{z i n}$, and hated the Tartars, with whom he was frequently at war. Thus, it could not be from them, that he had borrowed the cuftom of immolating human victims; but he found it already eftablifhed in China, where it is continued at the prefent day. Even the Jefuits authorife us to entertain great and melancholy fufpicions on that head, when they fay that the emperor Can-bi made a law to prevent the practice of facrificing flaves at the deceafe of princes of the blood; and yet, fome time after, women were ftrangled at the obfequies of $T a$. vang, brother to the emperor Can-bi. This execution is fo recent, that living witneffes of the fact might now be found at Pekin. Confidering the obftinacy of the Chinefe in perfifting to deftroy their children with a brutal ferocity fo well known, it is certainly not very aftonifhing to find them continuing to immolate human victims. Unenlightened as they are by philofophy, it is as difficult for them to make any progrefs in morality, as in the arts and fciences. At the funerals of private people, ftatues of paper, reprefenting male and female fervants, are always thrown into the fire; and we may prefume, that this ceremony was invented by poor people, who had no flaves to facrifice at their interments. Indeed we can eafily conceive that few, except the emperors and princes, were in a fituation to make fuch coftly offerings, Mr. le Gentil obferves on this occafion, in his Voyage round the World, that a great mixture of Indian cuftoms is perceptible at the funerals of 
the Chinefe. In fact their religion is a chaos of practices, adopted partly from the Indians, and ftill more perhaps from the Scythians, who, according to Herodotus, always interred fome flaves and concubines with the corpfe of their fovereign. - This is very conformable to the dreadful fcenes exhibited under Can-hi at the obfequies of Ta-vang.

The paffion of the Chinefe for the number nine mult likewife be counted among the fuperfitions they have in common with the Tartars. Many fteeples, or towers of nine ftories, are feen throughout the whole country, merely from a whimfical inclination for this number. The fame circumftance gives rife to the humiliating ceremony of bowirg nine times, on approaching the throne of the emperors of China; and we learn from the hiftory of Gengis-Kan, that it was likewife eftablifhed at the court of that prince*.

Among all the towers of nine ftories in China, not one is built of porcelain, as fome amplifiers have afferted in their relations. What gave rife to this fable is a fteeple in the neighbourhood of Nankin, in erecting which the Tartars employed bricks of a quality rather better than ordinary, and impreffed with figures by mears of moulds. Father du Halde, after giving a kind of defcription of this building, which he embellifhes as much as pofiible, by adopting the ftyle of Father le Comte, finithes with thele exprefions: : This, fays he, is what the Cloincle call the Porcelain. Toacer; although perlaps fone of our:

* Petit ce la Croix, Mift. de Gen his-kan. 
Europeans might affect to fyle it the Tower of Brick*. Thofe, who give it that name, are furely far from being blameable; for not a fingle piece of any thing like porcelain can be found in the whole edifice.

This tower is remarkable for a degree of folidity, very uncommon in the buildings of that country; and, in fact, it was not conftructed by the Chinefe, but by Koublai-Kan, in commemoration of his conqueft. On this account it has always been refpected by the Mandhuis, while many others in the vicinity of Nankin were pillaged and deftroyed, when that town was taken. Even the Tartars themfelves, although defirous of preferving more fevere difcipline, could not then reftrain their victorious troops; who, as the Chinefe pretend, among other exceffes levelled the royal fepulchres and fet fire to the facred groves. Anciently, indeed, prodigious tracts planted with cypreffes, ferved there as an inclofure to fome wooden edifices. But it cannot be confidered as a great misfortune, that fuch foreits, equally ufelefs both to gods and men, fhould be reduced to athes, that the foil, as is now really the cafe, might ferve for tillage. Nieuhoff, who vifited Nankin foon after this event, found tranquillity already re-eftablifhed in that town. We mut therefore confider as fabulous what Father le Comte has related of the Tartars having carried all the Chinefe women to market in facks; where he pretends they were fold, without diftinction of age or rank, to the higheft bidders. He even adds, that thofe, who perceived any figns

* Defcription of China, rol. ii. 
of decrepitude on the unfortunate beings they had purchafed in this manner, threw them without mercy into the river. This ftory feems to be founded folely on the cuftom of the Tartars, when they gain a battle, of cutting off the ears of the dead, and filling nine facks. We know how often they practifed the fame thing in Poland; as well as in Bo. hemia, at the defeat of the duke Henry, near Lignitz, in the year one thoufand two hundred and forty-two. Some corps of Eleuths and Calmucs having been vanquifhed by the emperor of China in one thoufand fix hundred and ninety-fix, he ordered their long hair to be cut off, and collected likewife into nine facks.

The Brick-Tower of nine ftories, concerning which we have already fpoken, is garnifhed on the outfide, like many others, with rows of fmall bells, and the noife they produce, when fhaken by the wind, is very difagreeable. Some have pretended that thefe chimes refembled what was feen on an Etrufcan monument fomewhere near Clufium; and the Etrufcans, they add, were clofely connected with the Egyptians, whofe works they copied continually. But we Thould obferve, that Pliny gives us very plainly to underftand, that the monument of Clufium never exifted. We are therefore at a lofs to know. whether Varro amufed himfelf with inventing this fable, or had really extracted what he relates from fome obfcure romance*. The idea of any great

- Pliny appears to infinuate that the defcription of the monument of Clufium was taken from that collection of fables. which he colls fabule Etrufca. 
intercourfe between the Egyptians and Etrufcans feems to be founded entirely on a paffage of Strabo, badly interpreted, added to the opinion of fome modern Italians. The Abbé Winckelman could not difcover any refemblance whatever in the monuments of thofe two nations, who, according to all appearances, were as little connected as the Laplanders and the Spaniards.

The Chinefe, perfuaded that nothing in architecture can be more magnificent than their tower of nine ftories, are conftantly forming models of fuch building about two feet high, and covered with mother of pearl. They endeavour to difpoie of fuch baubles to European merchants, taking care to add a certain number of thofe fmall ftatues, called idols by the miffionaries, but known to us by the name of Chinefe figures. They are certainly intended to reprefent tutelary genii, and local divinities ; for the numerous fteeples, concerning which travellers have propofed fo many conjectures, can be nothing but pagodas. Thence the alarm is fpread, in cafe of fire, and on thefe the hours are indicated by fand-glaffes, which are however far from being exact. Prior to the year one thoufand five hundred and fixty, not one good fun-dial could be found in all China: neither were any of the lettered there acquainted with the firft principles of gnomonics, or capable, fays Father Greflon, of calculating a meridian fhade.

With regard to the Pai-leou, generally believed to be triumphal arches, not one of them approaches what we call the New Gothic; and the greater part, 
as Father le Comte acknowledges, do not deferre confideration*. Yet the paffion of the Chinefe for thofe buildings is very great; and the fmalleft towns wafte much timber in that way, which would be much better employed in conftrieting huts for thofe miferable Troglodytes, concerning whom we thall have occafion to fpeak hereafter. It is neceffary to remark, that this was far from being the tafte of the Egyptians, who never had even a veftige of any triumphal arch, until after the conqueft of the Greeks, or rather of the Romans. What is feen in the environs of Enfons, or Antinoopalis, is a work of the emperor Adrian; and to me it appears to be nothing more than a portico.

Among the Pai-leou of China, none can be confidered, either froun their ftructure or characters, as very ancient; and Father du Halde confiders the infcription on the brazen column, erected, according to him, about the year fifty of our era, as furpaffing in antiquity all other monuments of the empire + . But that pillar; fuppofed to be feen on the frontiers of Tonquin, appears very fufpicious: no traveller can fay any thing with certainty further than that the Tonquinefe have covered it, as we are told, with a heap of fories; and confequently indeed not much is to be feen. Befides, when we attend to that long fucceffion of ages mentioned by all the chronicles of China, it muft be allowed, that an infcription of one thoufand feven hundred years is very modern.

- New Memoirs on China, letter iii.

$t$ Defcription of China, vol. $\dot{x}$. 
No circumfance has enabled us to form any judg. ment on fome characters, faid to be found on the Van-ly-czin; but if they have not been added, when the wall received fome repairs, we mut confider them as more ancient than the column of brafs.

Great fimplicity prevails in the interior of the Chinefe houfes, as well as throughout the other defpotic ftates of Afia; where the poverty of the people and continual diftrufts prevent the acquifition of much furniture. Riches are there buried in the earth, rather than expofed to fuch rifks; and the fame utenfils are employed to various purpofes. Yet neither in Turkey, nor Perfia, are fuch miferable families to be found as in China, where they are deflitute of all the conveniencies of life. Exclufive of thofe; who in the fouthern provinces live entirely on fifh, and remain conftantly in their barks without clothes of any kind, many have nothing more than holes in the earth for their habitation. Thirty lys from Ho-lou after having paffed Tchang-ran, fays Father Fontaney, whole families of Chinefe are feen living in grottos; for China alfo, he adds, has its Troglodytes*. Not far beyond the town of Ping-teng, great numbers inhabit caverns ten or twelve feet broad and twenty long, one of which frequently contains feveral families.

It is credible that thefe Troglodytes, rendered at times defperate by this mifery, affociate with the robbers and certain bands of men who wander with fome few flocks in the interior provinces, where no

* Journal of Travels from Pekin to Kianotctcheou. 
figns appear of agriculture. Their mode of living may be rendered more evident by the example of thofe Nomades in Spain, who wander with their cats tle from Lerida in Catalonia to the very plains of Andalufia, without finding the fmalleft obftruction in all that prodigious diftance. It is eafy to conceive, that, in a well-cultivated country, this could not be permitted, and that fuch flocks muft feed only on deferted fields or barren lands, where no perfon is interefted to have the limits afcertained. In the vaft folitudes of China, and even in thofe of Tartary, the monks of fome temples and bonzeries have formed commodious dwellings, and admirable gardens watered by rivulets, which are conducted from the mountains in artificial cafcades. Thefe hermits, who are nothing better than thofe of Europe, could not fleep one night at their eafe, if the banditti of China were lefs religious: but they refpect the pagodas, or pillage them only in the greatert extremity. It is befides poffible, that the holy men, who inhabit them, being in correfpondence with the robbers, affift in concealing their plunder. In this likewife a refemblance is found with the monafteries in the deferts of Spain and Portugal; and we may therefore pronounce woe to that country, which contains wandering thepherds and hermits.

Near the principal towns of China, fome villages here and there have houfes covered with tiles. On advancing into the centre of the country, the beft buildings are wretched cottages of mud, thatched with rufhes, and in many towns of the fecond rank 
clay alone is ufed for the walls of the dwelings. As the Chinefe have never fucceeded in glafs-work, nothing of the kind is feen even in the windows of their palaces. The faloon, where the emperor Canhi gave audience to the Ruffian ambaffador, fays Brandt, had wretched preparations of paper to admit the light*; becaufe the glafs-houfes eftablifhed by that prince were then, and are ftill, incapable of producing any thing to anfwer that purpofe. In fome provinces waxed filks, thells, and mother-ofpearl, are ufed for windows. This likewife is the cafe in the cathedral of Goa: but fuch fubftances admit very little light, becaufe they are lefs tranfparent than horn, or the fpecular ftone.of the ancients, of which fome fragments are preferved in the churches of Italy.

It is curious enough to fee the Chinefe forming artificial rocks in what they call gardens; and then afking Europeans, if their artifts could produce any thing fo magnificent. They might be anfwered, that to heap up ftones at random requires neither genius, art, induftry, tafte, nor any notion of the beautiful and ufeful. They would therefore act more wifely by fowing fuch fpots with rice or wheat, to render famine lefs fatal in China. We are affured

* Befchreibung einer groffen Chinefifchen Reife.-Brandt fays likewife that this faloon had no ceiling of any kind, fo that the roof was Seen in the apartment, as in moft of the Chinefe buildings, of which a tent has evidently been the model. The pillars, it hould be remarked, are not always round, but frequently cut into five and feven faces. 
that the empire contains two thoufand mountains; and nothing can be more foolih than to augment the number, inftead of endeavouring to render the country more level. Every perfon knows, without our dwelling on the circumftance here, that neither the Chinefe quarter, nor that of the Tartars in Pekin, contairs any temples or public edifices fuperior in ftructure or magnificence to thofe of the other towns. The emperor, who alone has the privilege of offering folemn facrifices to the genii of the $\mathrm{kyy}$, the earth, the mountains, rivers, and valleys, never performthe ceremony but under tents. This cuftom, which thould be confidered as very ancient, is likewife conformable to what we have faid concerning the primitive ftate of the Chinele, when they were wont to encamp like the Tartars. The tents employed for thefe facrifices, are pitched during the days of the folemnity in the Tien-tang, and the Ti-tang; and they are afterwards prefcrved with the facred vafes and tablets. Two particular houfes are deftined to receive them: the one, confecrated to the genius of the $\mathrm{ky}$, is round; and the other, facred to the genius of the earth, is fquare, according to the admirable cofmography of Han-li, and the profound know!edge of the lettered in China. They all agreed that our world is a cube, and not a globe; and the architects were obliged of courfe to comply in the beft manner they could with the decifion. Mr. Chambers, who did not attend to thefe circumAtances, is greatly deceived, when he compares the Chinefe pavilions to the monopteral temples of the ancients. 
ancients. By fuch extravagant inferences, all the parts of Grecian architecture might be difcovered in the palace of Pekin, as it is defcribed by Ifbrant Ides. Befides, Mr. Chambers does not feem to have been informed of a fact relating to the pagodas of $F_{0}$, feen in China : we are affured by a traveller, that their plan and interior difpofition refemble almoft in every point thofe of the pagodas of Hindooftan. Thus it is fcarcely to be doubted, that this mode of building was unknown to the Chinefe, prior to the introduction of the wornhip of Fo, the epoch of which is lefs ancient than our prefent era. Even admitting that Lao-kium had made a journey to India, as might well have happened, it is certain that he did not eflablifh the true religion of that country in China.

The ftate of architecture among the Egyptians is an immenfe fubject; but we thall endeavour to include in a few pages what feems moft interefting. Thofe people were always building : one great work produced another ftill more prodigious; and if fortune had preferved them from the yoke of the Perfians and of the Greeks, they would have endeavoured to level the mountains of Thebais, rather than remain idle. All their obelifks are fo much alike, that when they have no characters, it is very difficult to diftinguifh them one from another. It feems ftrange, that they did not grow weary of rearing fuch monuments; and yet among their laft kings we find Amafis and Nectanebus, continuing thofe laborious undertakings with as much ardor, as any of their numerous predeceffors 
Mr. Le Roy mult be deceived, when he pretends' that the ruftic fhed had been adopted by the Egyptians, in the fame manner that Virruvius fays it ferved among the Greeks, as a model for the mof fuperb edifices on earth *. Every thing tends to prove that the Egyptians, prior to their being united as a nation, lived like Troglodytes in the caverns of Ethiopia. Thus a grotto, rather than a cottage, muft have afforded the firft notions of their architecture. The favages of Greece, on the contrary, from the diverfity of foil and climate, which in fuch cafes has a great influence, were under the neceffity of erecting huts. No refemblance therefore ever exifted between the roofs of the Grecian temples and thofe of the Egyptians; and as the latter were entirely flat, they could not have been copied after the ruffic Jhed of Vitruvius.

Pharaoh Amafis caufed a huge piece of hollow rock to be brought from the vicinity of Elephantis, and placed it before the portico of the temple of Minerva in the town of Sais. The Greeks, who compofed words at will, called the interior of this ftone a monolithe chamber; and the firft idea of fuch an apartment muft evidently have been taken from a grotto.

When we reflect on the prodigious excavations, made continually by the Egyptians in their mountains, and the fingular predilection of the priefts for thofe caverns, where they paffed the greater part of their lives, it is no longer doubtful, that, in former times, they had lived like Troglodytes. Thence are

Ruins of the nobleft Monuments of Greece, vol. i. 
derived likewife all the characteriftics of their edifices : fome feem to be factitious rocks, where the walls exceed twenty-four feet in thicknefs; and pillars of more than thirty feet in circumference are not at all uncommon. If any thing can be compared to what thefe extraordinary people erected on the furface of the earth, it muft be their fubterra. neous labors, Some ancient authors had good information, that different apartments were conftructed an hundred and fixty feet below the pyramids, com. municating with each other by paffages, to which Ammianus Marcellinus has given the Greek name of fyringes *. The only one of thefe now known is that leading through the moft northern of all the pyramids; and it becomes every year more imperfect, from the rolling in of fand and ruins. Yet Profper Alpin affures us, that, about the year one thoufand five hundred and eighty-five, a man, hav. ing defcended there with a compafs, arrived at the place where the way divides into twa ramifications, one taking a fouthern, and the other an eaftern direction. This could no longer be traced by Maillet, Greves, Thevenot, Vanfleb, and Father Sicard, who came many years later; and as to Belo, his negligence in defcribing this monument is fuch, that what he relates does not deferve a perufal $t$.

Herodotus knew beyond a doubt that, after defcending below ground, a perfon could pafs into the

- Lib. xxii.

+ In the 228th page of his Obfervations he makes the thell of the great pyramid twice as long as it really is, 
apartments of the pyramid of the labyrinth. As this is exactly the cafe in that of Memphis; the interior difpofition of which is perfectly well known at the prefent day, we have every reafon to believe, that the fame mode of conitruction was common to the other monuments of that kind. They all muft have had fubterraneous vaults, and fecret paffages, like that difcovered in the thirtieth degree of latitude, which ever fince the time of Pliny has been impro. perly taken for a pit. Yet no water could poffibly enter there, any more than into the catacombs of Sakara, where the ground is till lefs elevated; for all thefe excavations are formed in calcareous fubftances, where no humidity can remain. Strabo has indicated a Serapeum, or chapel of Serapis, amidft the moving fands to the weft of Memphis, which appears to have been the real fpot where the mouths of the different gallerie, , leading below the pyramids of Gizeh, were united.

Among the crypts and grottos of Heptanomis and Thebais, thofe of Alyi and Hipponon are large enough to contain a thoufand horfes : we know thofe of Speos Artemidos, of Hicracon, Selinon, Antcoopolis, and Silfsi ; as well as the fyringes, or fubterraneous paffages mentioned by Paufanias, in the vicinity of the vocal ftatue * But although travellers meet with others every day, they have not yet difcovered the one hundredth part of fuch excavations. We cannot how. ever admit entirely the tradition, credited in ancient times, which reported that the whole town of Thebes

- Lib. i. in Attic. capi 42. 
was fituated over crypts, and that their ramifications extended under the bed of the Nile *. What might have given credit to this is the circumftance of certain grottos being really feen on the banks of the river, between Korna and Habou, where it is faid the firft kings of Egypt were wont to lodge, prior to the building of Thebes.

To the north-welt of Korna are thofe excavations, called by the Arabs Biban-el-Moluk. Concerning the purpofe to which they were deftined no doubt was ever entertained either by the ancients or the mo. derns. They are in fact the tombs of the firt dynarties, or royal families; and thofe, who place the bodies of the ancient Pharaohs in the pyramids, are egregioully miltaken. At Biban-el-Moluk not one fingle ftone has the leaft of a pyramidical figure; and this confirms us in the opinion, that none of the chambers in the pyramids of Memplois ever contained any mummies : but they were placed many feet below the foundation of thofe edifices, the form of which, in the Egyptian worfhip, had no refemblance to that of the tombs.

Some of the grottos we have mentioned contained embalmed bodies, and they were generally kept in an upright pofture, as occupying leaft fpace. That rule feems indeed to have been always obferved, except with the kings, who lay at full length in the farcophagi. We muft not give entire credit, as fone have done, to a paffage of Silius Italicus; which befides does not concern the attitude of the mummics

* Plin. Hit. Nat. lib. xxxvi. cap. 14. 
in the cells, but the manner of placing them in the houfes. This bad poet withes to infinuate, without any appearance of truth, that the Egyptians affembled their dead around the tables of the living *.

Egypt had likewife caverns, which were never ufed. as fepulchres: fuch was that of Diana, or the Speos. Artemidos, ftill feen at Beni-Hafan; and the figures, fculptured there, have certainly not been executed by the Greeks. Many others of the fame. kind were cut in the rocks of Ethiopia $\dagger$; where, we learn from Bermudez, the priefts initiated, or offered facrifices, and even retired to ftudy ${ }_{+}^{\dagger}$. We have been told of a certain Pancrates, who did not leave thofe dreary abodes during a period of twenty-four years; and it is generally fuppofed, that Orpheus, Eumolpus, and Pythagoras, were admitted there likewife.

On confidering this mode of ftudying under ground, it no longer appears aftonifhing, that the priefts contracted the habit of throwing a myfterious veil over all their real or imaginary knowledge. Thus, in many circumftances, it is as difficult to determine the extent of their erudition, as that of their

* - Esyptia tellus.

Condit odorato poft funus fantia bufto

Corfora; Eे à menfis exfanguem baud feparat umbram. Lib. xiii.

+ Alvarez, Rerum $\mathbb{E}$ thiopicar.

$\ddagger$ Propheta Asyptiorum non permittunt ut metalli artifices, fculptorefque Decs reprefenient, ne a recepta abeant forma; fed illudunt vulgo, dum in templorum atriis accipitrum ibidumque roftra fculpi curant, fubeuntes interea facra fubterranea qua profundis illorum myferiis relamcnto funt. S NFines. 
ignorance; and therefore fuch oppofite judgments have been formed concerning their philofophy, which fome confine to a very fmall fcale, while others confider it as almoft boundlefs : but it is truly interefting to obferve, that the cuftom of retiring into cells, practifed by the prients, gave rife to the myfteries of antiquity. Without this, none perhaps would ever have been invented; and wherefoever thofe of Egypt were received, the mode of celebrating them in caverns was likewife adopted, until the inftitution became at length effentially changed. Bifhop Warburton led all Europe into errors, concerning the pretended fecret revealed to the perfons initiated in Egypt, becaufe he confidered the letter, faid to be written by Alexander to his mother, as authentic. In fact it was the invention of fome Chriftian; and a groffer fraud was never practifed. Mr. Silhouette, who tranflated thefe fragments of Warburton, Thould have perceived the ridiculoufnefs of placing in Egypt a high-prieft called Leon. Never before the conqueft of Alexander did any Egyptian prieft bear that name; and it would not be more abfurd to pretend that an emperor of China was called Charles Martel *. Much more might be faid here, concerning the fuppofed letter, were it not now allowed to be apocryphal by all the learned of Europe. Befides, how could the initiated be told, that the gods of Egypt had been mortals, when it is known that the

* Mr. Silhouette cites this letter of Alexander to refute the Abbé Pluche, who belicved the mylteries were relative to agriculsure.

Egyptians, 
Egyptians, fo far from ever adoring deified men, held that kind of wormip in the greateft abhorrence?

The myfteries feem to have been originally a fecret inftruction, given only to the priefts, who, prior to their confecration, experienced a panic terror. They were afterwards conducted by dark windings to a place very full of light; and this fuggefted the idea of copying the phenomena of thunder and lightning, as we have already mentioned in the firt volume of thefe refearches. All the priefts of Egypt without exception were to be initiated, as Diodorus fays, in what were called the myfteries of the god Pan; and not one of them efcaped a panic terror in the obfcurity of the fubterraneous paffages *.

This tafte for myfteries and enigmas was introduced among the common people, and produced no inconfiderable effect on their character. It cannot be denied, that the deputies of the provinces, or Nomes, might at times in their affemblies have treated of fuch important matters as required the greateft fecrecy: but we muft allow that none, but the Egyptians, would ever have thought of affembling their national reprefentatives in a labyrintin, to which they were conducted by the moft ob.

* It does not appear that the Egyptians ever revealed the great myfteries to any who did not belong to the facerdotal clafs; except perhaps to Pythagoras. In time, every perfon who was nut guilty of fome public crime could obtain admiffion to the leffer myfteries. Thofe vagabonds called Egyptian priefts in Greece and Italy required confiderable fums for initiations; and the gypfies practife fimilar mummeries to obtain money. 
fcure windings, as Pliny attefts in pofitive terms *.

The Chinefe have no word in their language to exprefs a labyrinth; becaufe nothing approaches that form among all the edifices of their country. It may be boldly afferted, that they are incapable at this day of conceiving any idea of fuch a building, either from plan or defcription. Even the learned of Europe cannot flatter themfelves with having formed very accurate notions concerning the labyrinth; for although many. of its ruins ftill remain, yet travellers in general mifs the fpot, moft probably by directing their refearches too far towards the weft. Paul Lucas, who could not write, and his compiler Fourmont, may eafily be excufed for miftaking the ruins of the caftle of Caron for fragments of that fabric; but it is unpardonable in Father Sicard, and Mr. Pococke, to fall into the fame error. This pretended caftle of Caron, according to different plans, feems to have been a chapel of Serapis, fcarcely one hundred feet in length, without any appearance either of a pyramid, or labyrinth : while Strabo affures : us, that thofe perfons, who vifited the terrace of the labyrinth, faw around them a whole country covered with hewn ftones; and the view was terminated by an edifice of a pyramidical form.

Thus we perceive how many difficulties are encountered by thofe, who ftudy the monuments of a country, concerning which the moderns have con-

* Majorem autem in parte tranfitus elf per tenebras. Lib. xxxvi. sap. i3. 


\section{PHILOSOPHICAL DISSERTATIONS}

fpired with the ancients to give us falfe ideas. The latter indeed were probably deceived by being at the difcretion of a fet of men called Interpreters, whofe college was eftablifhed in the reign of Pfammeticus; and who might be compared to thofe people called Ciceroni at Rome. Philofophers, who were really defirous of acquiring information in Egypt, found it abfolutely neceffary to remain there during many years, as we find by the example of Pythagoras, Eudoxius, and Plato. But travellers, who only went and returned, like Herodotus, without knowing a word of the language of the country, could learn nothing but from the interpreters. Thofe men perceiving the inclination of the Greeks for the marvellous, amufed them like children with ftories inconfiftent with common fenfe, and unworthy of the majefty of hiftory. They probably invented the tradition adopted at this day, which fays that the pyramids were erected contrary to the advice of the priefts, who protefted in vain againft fuch undertak. ings. Yet we fee very plainly, that they were conftructed particularly under the direction of the facerdotal clafs; by whofe aid they received an exact pofition, either by means of the fhade of a ftyle, or from obfervations made on fome ftar when paffing the meridian. Their real object in this was never revealed even to Thales, concerning whom Pliny and Plutarch relate one very great falfehood: they pretend that he taught the Egyptians to meafure the height of the pyramids by the hadow, which could never be 
ON THE EGYPTIANS AND CHINESE.

done in the manner they defcribe *. Thales, on arriving from Miletus at Heliopolis, was as ignorant as poffible, and knew nothing of either mathematics or aftronomy; and the little knowledge he acquired afterwards was entirely due to the priefts of Egypt; whofe fcholar he had been for many years. Such a perfon cannot be fuppofed to have taught his mafters; and we muft conclude for his honor, that no report of the kind originated with him ; otherwife his ingratitude would be unpardonable.

Thofe people have fpoken without reflection, who pretend that the pyramids received a particular pofition, in order to obtain an unchangeable meridian, by which obfervations might be made to determine whether or not the poles are fubject to variation. In that cafe, one pyramid would have been fufficient, inftead of rearing fo many along the whole coaft of Libya, from Memphis to the labyrinth. Neither is it true, that they ever ferved as gnomons, whatever may have been faid to that effect by modern writers: the ancients took care never to affert any thing of the kind; perhaps from having already had fome notion of the confumption of fhade. Solnus, Am. mianus Marcellinus, and Caffiodorius, exprefs themfelves indeed in a very improper manner on this point; and all we can conclude from their argu-

* To obtain the height of a pyramid by its fhadow it is neceffary to meafure one fide of the bafe and know the middle. As Pliny and Plutarch do not reprefent Thales as beginning by this operation, we muft confider what they relate concerning this matter as fabulous. 
ments amounts to nothing more than that the pyras mids never calt the fmalleft thade at any time of the year or day. This, fays Marcellinus, proceeded from the mechanifm of their conftruction, mechanica ratione; but every perfon mult perceive, that his mode of reafoning is directly oppofite to the laws of nature *.

We hall here endeavour, in a few words, to explain this matter. The largeft of the pyramids, fituated in twenty-nine degrees fifty minutes and fome feconds north latitude, begins towards the vernal equinox to afford no thadow at mid-day beyond its bafe; and thofe, who then walk round this huge mals of thones upwards of five hundred feet high, never lofe fight of the fun. The architects mult have forefeen this effect, proceeding from the pyramidal form of the edifice; and the meridian thade during one half of the year is confined to the northern face, without ever reaching the earth. Thus nothing more imperfect, as a fun-dial, could be invented than the great pyramid, by which even the period of the fummer folftice cannot be afcertained; becaufe the fhadow is then too high to be diftinctly perceived. Yet the celebrated chronologif Vignoles fuppofes that the priefts calculated the equi-

* Solnus, Polyhift. cap. 42.-Am. Marcel. Hift. lib. 22.Caffidor. Variarum, lib. 7. As Solnus appears to have been the firft propagator of this error, we thall quote his own expreffions: Pyramides turres funt in IEgpto faftigiate ultra celfitudinem omnem, que fieri manu poljt, itaque menfuram umbrarum egrefle, nullas babent umbras. 
noxes by means of the pyramids * ; but he would never have formed this opinion, had his plans of thofe monuments been as exact, and his maps of Egypt as good, as thofe now publifhed.

It thould be remarked, that the Egyptians obferved no determined proportion between the breadth of the bafe, and the height of the pyramids. As their dimenfions varied fo confiderably, no idea could be had of having recourfe to them, in order to find out the equinoctial days; which, according to Macrobius, were indicated by fimple ftyles, or, as others pretend, by water-clocks. One fact was entirely unknown to Vignoles : the pyramid, called el Harem el Kieber el Koubli by the Arabs, has a bafe much broader, in proportion to its height, than the great pyramid of Memphis. Thus beginning much fooner than the other to caft no thade at mid-day, it cannot ferve in any manner to indicate the equinoxes. Befides, it may be appofite to ank, what means were em. ployed by the priefts of Thebes, who had no pyramid in all their country, whatever Abulfeda has afferted to the contrary; and yet their college was the

- De Annis Egyptiac. in Mifcell. Berolin. tom. iv. It is merely an effect of chance that the great pyramid begins towards the equinox to confume its thadow at noon; for in fome of the others this phenomenon is obfervable fooner. We can fay with certainty that the greatef meridian thade of the pyramid of Gizeb and all the reft indicates the winter folftice : but it mult have been very difficult to afcertain that of the fummer; and befides, all fuch obfervations were rendered inaccurate by the pen. umbra. 
firft in Egypt, as well for aftronomical knowledge, as in point of antiquity.

We muft not therefore attribute views to the Egyptians, which they could not have entertained without difcovering a total want of common fenfe. For furely a fimple dial-pin is better adapted to afford exact indications in fuch matters, than any mafs, where the thade muft be fo greatly impaired.

The pyramids, as well as the obelifks, were monuments erected in honor of the Being who enlightens the univerfe; and this determined the priefts to give them a particular pofition. Sepulchral cells might have been conftructed within thefe edifices, fufficient to contain the bodies of all the royal family. Yet only two apartments are hitherto difcovered, and one fingle cheft, which, in oppofition to the opinion of Strabo, many enlightened travellers, fuch as Doctor Shaw, do not conceive to be a farcophagus, where any carcafe was ever depofited; and, in reality, the thing is very improbable. Endlefs conjectures have been hazarded; but hitherto no writer has reflected, that this cheft might be what the Egyptians called the Tomb of Ofiris. Many fuch were found throughout the whole country ; and the fuperItition, attached to their confruction, confifted in making the rays of the fun defcend around them, without caufing any thade on the ground at mid-day, during at leaft one half of the year. This pheno. menon continued longeft in the fouthern pyramids of Illabon and Hauara, towards the extremity of the plain called Cocbome; and from their ruinous ftate, 
they may be confidered as more ancient than thofe of Memphis. The latter are thought ftill capable of refifting the lapfe of five thoufand years, according to a calculation formed on the progrefs of their decay. fince the days of Herodotus. That hiftorian mentions many figures and characters on the exterior of thofe edifices, now no longer vifible; but Mr. Norden fpoke without reflection, when he afferted, in his Journey through Nubia, that they were conftructed prior to the invention of hieroglyphics. Such miftakes fhock all notions of hiftory; and it were to be defired, that the greater part of travellers, before their departure, or at leaft after their return, would take fome pains to improve their ftudies.

The priefts of ancient Egypt, by determining fo very accurately the pofition of the pyramids, have enabled us to afcertain, that no variation has taken place in the direction of the poles. In vain fhould we look on the whole furface of our globe for any other means of obtaining this information. Had Chaldæa ever poffeffed edifices equally folid with thofe of Egypt; fome prodigious ruins would fill be found there: but from being formed of brick and bitumen, all the higher parts foon fell afunder; and fome remains are difcovered only at a few feet above the foundation, where the tenacity of the bitumen has been preferved by the humidity. This is moft remarkable in a place fuppofed to be the fite of a temple of Belus; but fuch matters do not deferve inveftigation. Befides, in no country do we find Chaldæan ftatues, or monuments; while all the cabinets 
of Europe are furnifhed with Egyptian antiquities。 We may confider as the greateft exaggeration what Ctefias and Diodorus Siculus relate of an obelik, attributed by them to Semiramis, of which no perfon however could Speak from his own knowledge *. Egypt, on the contrary, muft have exhibited more than eighty of the largeft fize. The operation of erecting them was not very difficult aniong people, who, from having tranfported many fuch maffes, had acquired an experience, which Fontana wanted, when he employed fix hundred men, and one hun. dred and forty horfes, upon that of the Vatican. The power of the cables and captans being known, it is calculated, that this force would have been fufficient to raife ten thoufand pound weight more than was neceffary on that occafion $\uparrow$. As the Egyptians did not place their obclins on fuch elevated pedeftals as thofe fo improperly employed at Rome, they might, with four hundred men and eighty: horfes, have managed any montment of that kind, even with captans alone. The ftory, told by fome authors, concerning one of the Pharaohs, who, they fay, tied his fon to the top of one of thefe ftones to make the workmen more cautious, is too notoriouny: abfurd to require refutation. By examining attentively the form and pofition of the obelifks of Egypt, it is eafy to perceive, that they could never be intended as gnomons, according to the opinion fo pre-

* Jackfon, in his Chronological Antiquities, proves that no fuch obelink erer exifted at Babylon.

+ Epittola de Obelifco Romx. 
valent in Europe: Two were placed at the entrance of the temples; and when thofe buildings could be approached by different ways, the number of fuch fpires was augmented in proportion. This is evident at the prefent day, in the ruins of the temple of Phylæ; in that of Thebes; and at the fuppofed tomb of Ofymandyas; a word evidently compofed of Mendes and Ofiris.

Thus we find, that nothing like gnomors was the object; otherwife the abfurdity is evident of placing them fo near each other, that their fhadows muft frequently be confounded together. Befides, the upper part, called the pyramidium, could not give any precife indication without the addition of a globe, like that employed at Rome under Auguftus and Conftantius: Nothing of the kind however is mentioned by any ancient author, as having been practifed by the Egyptians; and we fee, by the paintings taken from the ruins of Herculaneum, and ftill better by the Paleftrina Mofaic, that the obelifks are invariably reprefented without a globe, or any place to infert a ftyle, or bar. When a Roman, named Maximus, was prefect of Egypt, he cut away the point, in order to place a globe on the obelifk of Alexandria ; and this muft have appeared to the Egyptians as facrilege. Thus the members of the Academy of Infcrip. tions at Paris were very ill informed, when they made their report to the Academy of Sciences, relative to the antiquity of fupporting globes with obelifks *: for fuch was never the practice of the Egyptians.

- Memoirs of the Academy of Infcriptions, vol. iii.

E 2

Apion, 
Apion, the grammarian, indeed pretends, that Mofes placed concave hemifpheres on pillars, inftead of obelifks; but he fpeaks like a perfon altogether ignorant of the matter; and Jofepl us who was a ftill worle reafoner, and more ignorant in natural philofophy, refutes him by the moft pitiful arguments. Vitruvius, Cleomedes, Macrobius, and Martianus Capella, defcribe the folar time-keepers, ufed in Egypt, by which Eratofthenes meafured, or verified the meafure of the earth *. According to them; they were really concave hemifpheres, with a ftyle raifed perpendicularly in the middle; but it is truly ridiculous to juttify Apion, by fuppofing that they could be placed on the top of obeliffs, or high pillars, where no perfon, without the aid of a ladder, could obferve the declination of the fhadow. Although the priefts frequently had recourfe to thefe inftruments, they efteemed ftill more their hydrofcopes or water-clocks, becaufe they could employ them during the night in aftronomical obfervations. Yet it is difficult to believe Orus Apollo, when he fays that they emptied themfelves precifely in an equinoctial day $t$.

We have never had an opportunity of feeing either the fand-glaffes, or clepfydras, made in China; but yet we know that they do not reprefent a monkey difcharging urine. The priefts of Egypt thought proper to give that whimfical form to their water-

- Vitruv. Architect. lib. ix.-Cleomed. de Meteorolog.-Macrob. in Som. Scip. lib. i.-Mart. Capell. de Geometria.

+ Hieroglyph. lib. i. 
clocks; which, befices, were graduated and divided in another manner than thofe of China. Twelve Egyptian hours are only equal to fix with the Chinefe*; and this is of more confequence than we are led to believe at firft view; for in fact it is not lefs effential than the different modes of dividing the figns of the zodiac in thefe two countries, where no refemblance can be found beyond what might well have proceeded from chance.

This is not the proper place to examine, what fhould reafonably be thought of the infcriptions on the obelifks. Father Kircher has made every effort to perfuade us, that they contain neither hiftorical facts, nor narratives of any kind; but he did not know that thefe characters are totally unconnected with what properly conftitutes an obelifk. No lefs than three of the largeft fize are known to have been pure, that is to fay without any appearance of engraving on the four faces, although they were certainly placed during many ages at the entrance of the temple of the Sun. Yet we cannot accufe the priefts and fculptors of ignorance in hieroglyphics, as Hardouin ridiculoufly infinuates, when fpeaking of one of thofe dumb fpires, erected by Nectanebus $f$.

Abenephi, the Arab, and many others, who are not his countrymen, have confounded the obeliks with the pretended hermetic columns. To prevent further confufion, it is neceffary that we fhould intro-

- Bayer de Horis Sinicis.-Ulug Beig de Epochis celebr.

t Plin. lib. xxxyi. cap. 14. 
duce accurate ideas and fixed terms in what relates to thefe two kinds of monuments; fo totally unconnected *.

Manetho, in compofing his hiftory of Egypt, con: fulted the Stele of Hermes, preferved in the fyringes, or fubterraneous paffages + ; but we do not find that he had ever recourfe to the infcriptions on the obelifks. The word Stela, or Hermetic Column, muft not however be taken in a literal fenfe; for that kind of monument was at beft only a cippus, and more frequently a mere tablet of ftone. The Arabian alchymits were well informed of this, when they called the flat emerald, mentioned in the preceding fection, the fmaragdine table; as others have been called the tables of the decalogue.

Ancient writers in general confirm what Manetho fays of the hermetic Stele being preferved in the moft fecret part of the temples, fuch as the adytum, and in the cells where the priefts retired to ftudy 1 . By this we find how different they muft have been from the obelinks, which were expofed to public view at the entrance of the principal edifices. On monuments, fo generally feen, and fo fignificant from their figure, engraved characters were not effential, but the infcriptions alone conftituted the hermetic Stelc.

Mr. Jablonfki, whofe authority muft ever have great weight in all fuch matters, has proved by in-

* Abenephi, apud Kirch. in Obelifco Pamphilio.

† Syncel. in Chron.

\pm Apotelefmat. lib. v.

vincible 
vincible arguments, that the Thoth, Mercurius Trifmegifus, and Hermes of the Egyptians, is a mere mythological fpectre, and not any perfon who really ever exifted". Yet the diftinction he makes, between the ancient and modern Hermes, is not altogether perfect. The time of the firft Hermes fhould be confidered, properly fpeaking, to continue as long as the priefts confined themfelves' to engraving their hieroglyphics on ftone; and the cra of the fecond began when they employed books of papyrus; becaufe with them even to touch parchment was unlawful. As thofe men always fpoke allegorically, they have led our modern chronologifts into innumerable errors. It is with a fmile mixed with compaffion that we read the controverfies of thefe pretended calculators, concerning the real period when Hermes lived : they might as well difpute about the reign of king Oberon.

Pliny may be confidered as under a miftake, when he pretends that the obelink feen in Heliopolis, at more than one huncired and fixty leagues from the place where it was hewn, muft be the moft ancient. He fell into this error, becaufe the Greeks fometimes employed the word Heliopolis to denote the town of Thebes; where, apparently, the firft obelifks had been placed before the temple of Jupitcr Ammon, to adorn the capital of Egypt. Some modern geographers have followed very uncertain indications, in fixing the extent of that town; and Mr. D'Anville, who fuppofed its circuit to have been nine leagues,

* Pantheon $\mathbb{E g g y p t}_{\text {gib. v. }}$ 
has exceeded all bounds of probability. The Jefuits, who are known to have exaggerated greatly every thing belonging to China, give Pekin fix leagues in circumference; and it would be reduced to two, if the houfes were of three ftories, inftead of being wretched ground-floors, which require more furface than the regular buildings of Europe. Yet four hours are fufficient for riding conveniently on horfe-back round this kind of Chinefe camp, which a fpark of fire may reduce in one day to alhes, with. out leaving even a ruin; while Bufcowich fufpects, that, after the deftruction of Conftantinople, fome fragments at leaft might remain of its mofques and befefteins *.

The houfes of Thebes, according to Diodorus, were of four or five ftories; and, in that cafe, a cir. cumference of nine leagues would fuppofe a greater heap of houfes than ever was feen upon earth, with. out even excepting Babylon, where apparently many dwellings had but one floor. By making a diftinction between the town of Thebes, and the villages fcattered along the banks of the Nile, every thing marvellous will difappear. Dydimus, who muft have had fome knowledge of an actual furvey of that place, calculates the whole furface at only three thoufand feven hundred arouræ; and thus we find a town müch lefs than Paris. The conftant contradictions and variations of the ancients, concerning Thebes, prove the uncertainty of its limits; but, pro-

* Journal of Travels from Conftantinople to Poland. 
perly fpeaking, the buildings on the Libyan fide did not belong to that city *.

Memphis was computed to be three leagues in circumference. This eftimate muft have included the great ponds, now entirely filled up, the park, or accafia, fycamore, and palm-trees planted in clufters, and all the royal manfion of the Pharaohs. It is known that the palace extended from one extremity of the town to the other; becaufe moft probably the feraglio, chapels, ftables, and other out-houfes, adjoined the principal dwelling. Menphis, however, augmented only in proportion as Thebes declined. The ftate of population in Egypt did not allow thefe two cities to flourin at the fame time; and when Mr. Origny afferts, that twenty thoufand towns would not have injured the cultivated lands of that country $f$, we can only fay, that this refembles his other dreams concerning the ifle of Elephantis. Its extent, according to him, was prodigious; although, from what we have already obferved, the reader muft perceive that it formed merely a point in the Nile.

Memphis in turn ceded to the increafing grandeur of Ptolemais and Alexandria. Another revolution of the fame kind took place, on the building of

* No two ancient authors agree with-regard to the fize of Thebes. The affertions of Dydimus cannot be reconciled either with what Cato quotes from Stephen of Byzantium, or with the accounts of Diodorus, Strabo, or Euftathius. They are all in contradiction to each other. The extent of Avaris, fituated in lower Egypt, muft likewife have been greatly exaggẹrațed.

+ Egypte ancienne, tom. i.

Cairo ; 
Cairo ; and modern travellers have been as much deceived in the fize of that town, as of Thebes. We may be affured, that its circuit never amounted to three French leagues, or eight Englifh miles, as fome have falfely afferted.

- If Diodorus has given too much eleration to the houfes of ancient Egypt, they have been no lefs mifreprefented by Mr. Pococke, who pretends that they were nothing more than tents; and according to this idea, an Egyptian town confifted of an encampment round a temple. But he is the only perfon, who ever accufed the Egyptians of that manner of life, which they held in fuch averfion, that they would not permit even the Jews to live in tents. The Turks ought in good policy to have acted in the fame manner, with regard to the Bedouin Arabs, who, by continuing to encamp, bring ruin on the different provinces; and the maxim of preventing whole families from leading a wandering life, thould be ftrictly obferved in every country.

Having proceeded, as we propofed, to place limits to the too great extent of Thebes, it is equally neceffary to undeceive ourfelves : with regard to the temples of ancient Egypt. They were certainly much lefs numerous than many authors believed, before the different ruins had been well afcertained. It is generally underftood, that the trunk of the palm-tree was the model for the columns of all thefe edifices: but, in that cafe, they would have preferved a general re, femblance; and, on the contrary, nothing could be more varied. The fame thing is remarkable in their chapiters : 
chapiters: thofe in the form of a bell reverfed have been adopted in the Corinthian order; and the body of that chapiter is ftill called campana. Thus the adventure of the balket, found by Callimachus, fupported by leaves of acanthus, is nothing more than a childih fable, invented by the Greeks, who winhed to conceal their having borrowed any thing from the Egyptians, while the contrary is manifeftly evident. They pretended likewife that the triglyphs of the Doric order reprefented the ends of the beams refting on the architrave. But they were invented by the Egyptian architects, or fculptors, who never employed wood; and the Greeks have only added the gutta, which do not feem very neceffary. It is remarkable, that among all the ruins of Egypt, no columns have been found with vertebræ alternately of black and white marble. Yet the Egyptians certainly efteemed greatly fuch particolored buildings, although their effect muft be truly difagreeable. But we fhould always remember, that the eyes of the inhabitants of the Eaft are very different from ours.

Only one inftance prefents itfelf, where the trunk of the palm-tree might really have been ufed as a model for colunins. This was to fatisfy the tafte of Pbaraols Amafis, who caufed many wonderful works to be conftructed in the town of Sais only a few years before the fall of the Egyptian monarchy. Hence we may perceive, that the paffion for building never diminifhed in that country, where the heat of the climate, and the fertility of the foil, naturally inclined nankind to idlenefs. Ariftotle juftly fufpected that 
the priefts did not wih the people to remain inactive *. Independently however of all political motives, they feem to have been perfuaded, that exercife was neceffary for the prefervation of health among men fubject to the leprofy; and frequent feftivals were inftituted to prevent their toils from becoming infupportable. In a climate fo ardent as that of Egypt, this management was very proper; although not at all calculated for colder regions, where the bodily forces are much lefs exhautted in an equal fpace of time. If all the colleges of Egypt really teftified their difcontent againft king Cheops, it was not furely from any difgult at the pyramid he erected, but becaufe he forced the people to work on holidays. Yet the whole recital of that affair, given by Herodotus, feems to be a pure fiction, contradictory of all ideas we have received concerning the government of Egypt, which was much lefs defpotic than modern authors pretend. It is ridiculous to hear them alledging, that, in a free country like England, no perfon would ever think of rearing pyranids; while we know, that the cultivation of the earth requires nine times more labor there than inEgypt. If exactlifts could be procured of all the Britifh fubjects, who perith at fea either by thipwrecks or other accidents, we thould find that navigation deftroys more men in one year, than perihed in many centuries by erecting the pyramids. As agriculture did not afford fufficient enployment for the Egyptians, who had neither a ma* rine, nor any exterior commerce, it was neceffary to

-Ariftot. de Republic. lib. r.

direct 
direct them to other purfuits. By reflecting on the flourining ftate of their country under the Pharaohs, and the miferable fituation into which it was reduced by the Chriftian emperors, and afterwards by the Turks, we cannot refrain from being perfuaded, that the ancient government muft have been better than fome men of trifling genius pretend.

One event has been greatly exaggerated ; and even allowing the whole to be literally true, we can only confider it as an accident altogether unforefeen. Pharaoh Neclso, it is faid, in caufing a communication tobeopened between the Nile and the Arabic gulph, occafioned the death of one hundred and twenty thoufand men. But how can it appear probable, that fo many hould perifh on this occafion, when Ptolemy Philadelphus completed a canal of the fame kind in another place, without the lofs of a fingle life?

Such popular reports may be accounted for in the following manner. The priefts of Egypt difapproved highly of the project of joining the Nile with the Red Sea. They even publifhed an oracle, to prevent Pharaoh Necho from his enterprife; becaufe their exact local knowledge enabled them to forefee, that fuch attempts would be ufelefs. The event juftified their opinion, when Ptolemy afterwards endeavoured in vain to eftablifh a harbour for the commerce of India, and the coaft of Africa, in the place where his canal entered the Arabic gulph. It became neceffary to form a port much more to the fouth; and thus the labor of cutting acrofs the ifthmus of Suez was entirely loft. Strabo certainly erred greatly, by affirming 
affirming that large veffels, heavily laden, had navi: gated this cut; for we know that Cleopatra, at a crifis when her life and empire were at ftake, could not pafs there, even with light galleys. The Turks were made to believe, in our own days, that if they wifhed to obtain immenfe riches, nothing more was neceffary than to open the ancient communication between the Nile and the harbour of Suez: but the perfon, fent to examine the matter, diffuaded the fultan from this abfurd project. If a prince like Ptolemy, who already poffeffed one branch of the commerce of India, could not reap any advantage from this canal, what indeed might be expected by the Turks? They have there only twelve or thirteen veffels; and thefe never leave the Arabic gulph, but are employed in tranfporting certain productions of India to Giddalj, whence Europeans bring annually to the amount of fix or feven hundred thoufand pounds fterling. Confidering the loffes of the Turks by thipwrecks in returning from Giddab to Suez, it is evident, that they would avoid much rilk by difcharging their cargoes at Bercnice, and following the road by land, as was practifed under the Ptolemies. Two tribes of robbers, or Bedouin Arabs, called Beni-Wafel and Arabdé, might indeed be tempted to lay the caravans under contribution; and as the Turks govern fo badly the countries fubjected to their fway, it is but juft that they fhould experience thofe . wrongs which they do to others.

To form an exact idea of the formation of the lake Moris, it will be neceflary to obferve the map at the 
beginning of this volume, where it is placed to the north of the town of Crocodiles, or what is now called the province of Feium. Father Sicard erred egregioufly in placing the lake too far to the fouth, and converting it into a long canal parallel to the bed of the Nile. Mr. D'Anville has unaccountably adopted the fame arrangement, although in oppofition to fuch geographers as Strabo and Ptolemy, as well as hiftorians like Herodotus and Diodorus. The laft of thefe writers fays pofitively, that the Mœris was little diftant from the town of Crocodiles *; and this paffage, which contributes to determine its real pofition, muft have efcaped the attention of .Mr. D'Anville t. Befides, the inhabitants of the country affured Herodotus, that this lake communicated with the Syrtis of Africa by a fubterraneous conduit, directed towards the weft, and paffing behind the mountains of Memphis. No other body of water anfwers this defcription, except that now feen to the north of the province of Feium; and as Ptolemy and Strabo fpeak with certainty, we may be affured, that this is the real Maris. Thus D'Anville's Egypt has one falle-indication, and the error is copied in his great

- Bibliot. lib. ii.

f This geographer withes to prove in his Memoirs on Ancient and Modern Egypt, that Herociotus and Diodorus, in fpealing of the lake Maris, have taken the meafure of the furface for the circumference. An error of this kind would be inexcufable in a child of ten years old. The Grecks could never be acculed of fuch imbecility; but they were alway's notorious for their exaggerations.

- map. 
map, becaufe he confided too much in the memoirs of Father Sicard, who was prevented by an untimely death from perufing ancient authors with fufficient at tention. In confequence of fuch improper combinas tions, D'Anville's map points out two labyrinths, al: though one only was known to the ancients; and Egypt was certainly not the place to multiply objects without neceflity.

At this day, the lake Mœris is thirty miles in length, and eight in breadth. That fpace is fufficiently extenfive to admit of various conjectures from thofe who meafure it with the eye only at different points of view. From eaft to weft, it appears larger than reality; and proportionably fmaller, when feen from north to fouth. As no naturalift has had an opportunity of examining it, we are at a lofs to determine whether it hould be confidered as formed by the water of the Nile, which enters there, or, according to Strabo, as merely a veftige of the Mediterranean. Perhaps indeed the Egyptians may have labored to drain the province of Feium, or the Arfenoite Nome, which appears to have been anciently a marh, as well as the Dclta. Having fuc: ceeded in that undertaking, they conducted thither the freh water, by cutting apparently feven mouths, by which a part of the Nile was difcharged into the lake Mœris, in the fame manner as into the fea *.

* Of feven mouths which belonged to the canal of communication between the Nile and the lake Maris, fix can now be diAtinctly obferved when the river overflows and the dykes are opened. 
After thefe explanations, we fee why the Egyptians could boat that this lake was produced by their induftry. Confidering the utility of the work, we willingly pardon their fuperftition, in fuppofing a connexion between the mouths of their canal and the number of the planets. We have no information whatever concerning the fubterraneous communication of the lake Mœris with the Syrtis mentioned by Herodotus. As that Greek did not, underftand the Egyptian language, he was perhaps milled by the interpreters, and poffibly alluded to what is called the River without Water, which fome travellers are perfuaded has never been produced by human labor. But the error of Father Sicard was occafioned by the mark of fome great canal, or an ancient bed of the Nile, called Batben in the French maps, and in the German Gara:

The Egyptians were infinitely more expert at con ducting water, or digging ditches, than erecting any fuperb and regular buildings. The great temple of Heliopolis, where neither labor nor expence was fpared, could only be confidered, fays Strabo, as a barbarous fabric, deftitute of tafte and elegance. It is with architecture as with painting, fculpture, and mufic. The people of the Eaft could never bring that art to any great degree of perfection; becaufe their fancy was too unruly to be governed by fixed principles.

Count Caylus has afferted, that the architects of Egypt were ignorant of the method of conftructing vaults; and Mr. Goguet wilhed to demonftrate this

vol. II.

beyond 
beyond difpute, by engraving defigns for the purpofe, in his book on the Origin of the Sciences and Arts. Cornelius de Bruyn, however, having been enabled by means of flambeaux to obtain a drawing of an obfcure gallery in the great pyramid, gives his opinion, that it was really a vault*. Pliny fays the fame of the inferior apartments of the labyrinth. Thevenot found likewife fome caves, intended for nummies, formed in that manner; and finally, Pococke difcovered an Egyptian arch in the province of Feium. Thus Mr. Goguet and Count Caylus do not appear to have examined thefe matters with fufficient attention. Indeed the difficulty of finding wood for fcaffolding and frame-work, might have prevented the Egyptians from vaulting the great temples; or perhaps that mode of building was not confidered by them as fufficiently folid, according to their ideas of indeftructibility. Every perfon kriows the extreme fcarcity of timber in that country; and to lay flat ftones on the tops of pillars required few fcaffolds: but whole forefts would have been neceffary to raife a vault for the prodigious temple of Thebes.

The Egyptians were the firft people who conceived the idea, that a whole country might be fortified like a citadel; and the great rampart of Egypt mult be confidered as much more ancient than that of Media. Sefoftris, who has been fo improperly confidered as a conqueror, endeavoured to put his own kingdom

* Reizen door klein Afia. This traveller gives the name of Gerwelf to the top of the gallery, and he would never have ufed that term without intending it to exprefs an arch. 
into a ftate of defence, by erecting a wall in an oblique line from the town of the Sun, fituated without the Delta, to Pelufium. This diftance amcunted to fifteen hundred ftadia of the fmalleft meafure, or about eighty Englifh miles; and the pretended hero was chiefly defirous of preventing the thepherds of Arabia from invading Egypt, where their exceffes were intolerable. What muft be confidered as very remarkable is, that the Bedcuin Arabs, who encamp at this day fo infolently on the ruins of Alexandria, have preferved the tradition of this great wall, fo injudicioufly conftructed. It ended, as we have faid, at Pelufium*; and when once an eneny got poffeffion of that town, all the works of Sefoftris were ufelefs; becaufe no obftacle afterwards remained in afcending the Nile, as we find by the fucceffes of Cambyfes, and afterwards of Alexander.

This great rampart of Egypt has totally vanifhed, no perfon knows in what manner. We have reafon however to believe, that it was levelled during the conqueft of the Perfians; for nothing of the kind exifted in the reign of Artaxerxes Mnemon, when the Egyptians, fupported by the auxiliary troops of Lacedæmon and Athens, made a laft, but ineffect:al effort to break their chains. Pharaoh Nectanebus

* Diodor. Bibl. lib. i. Egypt might have been more eafily inclofed by building a wail from Pelufium to the town of Heroes. It appeared to me at firt that the text of Diodorus was ineorrect, and that 'Hevwira Some confiderations afterwards prevented me from adheinig to that opinion. 
then fortified anew the whole Pelufian branch of the Nile; and Chabrias, the Greek, who commanded under him, clofed a fecond time the avenues of Pelufium by a bulwark called Charax Chabria* * But thefe works have difappeared, as well as thofe of Sefoltris; and we only find them in hiftory, as laid down in the map annexed to this volume.

Mr. Maillet pretends, that fome traces are feen of another wall, upwards of twenty-four feet thick, conftructed by the Egyptians in the Heptanomis $f$. This however is not mentioned by ancient writers; and it muft be confidered as rather fufpicious; unlefs per. . haps fome fuch method was adopted to protect the plain now called Araba. That diftrict might in reality have had cultivated lands, near Alabaftinopolis, where a defile between two mountains required perhaps to be defended.

This mode of inclofing a country with walls has been confidered as the ftrongeft proof of the refemblance between the Egyptians and Chinefe. It will therefore be neceffary to fhow, that the fame idea oc. curred to all ancient polifhed nations, whenever they had for neighbours the Nomades, who never cultivate the earth, and are the fcourge of civilized focieties. Paftoral life has been confidered by hiftorians, who were not philofophers, as the real ftate of innocence; but it is, in fact, fuch an incitement to rapine, that the terms Nomades and robbers are almoft fynonimous.

- Cor. Nepos in Vit. Chabriz,-Strabo, Geograph.

+ Defcription of Egypt. 
One great wall, which, on confidering the pofition alone, feems to have been judicious enough, was erected in the valley between the Libanus and AntiLibanus, to reftrain the Scenite Arabs. Although. amazingly ftrong, this work was already fo completely deftroyed in the days of Pliny, that he fpeaks of it as a monument no longer to be feen; but we find it defcribed particularly by Diodorus Siculus *

The Hebrews likewife, however ftrange it may appear, undertook to build a wall of an hundred and fifty ftadia, from the town of Foppa to Antipatris $\uparrow$. This rampart, like all the reft, was foon overturned; and the Jews, who pretended to defend it againft Antiochus, fuffered themfelves to be defeated in a moft fhameful manner.

On the way from Foppa, along the coaft of the Mediterranean, we find the great wall, which furrounded all the province of Pamphylia, and a part of Pifidia. Towards the end of the feventeenth century, fome travellers, on their journey from Anthalia to Smyrna, difcovered the wrecks of this vaft bulwark + , concerning which authors are fo filent, that we neither know when nor by whom it was erected. Yet no doubt remains but the object was to protect Pamphylia againft the Ifaurians, who were ever averfe to good order. Their mountains were naturally arid ; and inftead of endeavouring to improve the foil, they only thought of making incurfions wherever any

* Plin. lib. v.-Diodorus, lib. xiv.

$\dagger$ Jofephus, Ant. Judaic. lib. xiii.

\$ Spon, Mifcell. erudit. Antiquit. fect. vi. 
hope could be entertained of pillage. They were called the chief of robbers, in preference to the Jews and Arabs; and in this profeffion they difcovered al. molt as much expertnefs as the Algerines in piracy. The Romans chaftifed them repeatedly ; but they be. came again formidable under Valens, and his fuc: ceffors; and we may therefore, without further de. tails, confider this rampart as a work of the lower empire.

Paffing thence into the centre of Afia, we find the great wall of Media, extending nearly from the Tigris to the Euphrates. Xenophon, the only perfon who fpeaks of it from his own knowledge, fixes the length at twenty parafangæ *. This does not agree with what we learn from Lucius Ampelius $t$, who is unpardonable in confidering it as one of the wonders of the world. The height indeed was an hundred Grecian feet, and the breadth at leaft twenty; but yet it had no title to be ranked among the greatert of all human productions. As the ftones were cemented with bitumen, it was eafy for enemies, by means of burning cakes of the fame fubftance, to calcinate the places where they withed to open a paffage. Artaxerxes, to prevent fuch accidents, caufed large ditches to be dug before it, and filled with the water

* Retreat of the 'Ten Thoufand.

$\uparrow$ De Mirabilibus, cap. ix. The thirty Roman miles given by Ampelius to the wall of Media make only ten parafangx. His text fhould therefore be changed to fixty miles, which are within thirty fathoms of the twenty parafangx mentioned by Xeno. phon. 
of the Tigris. Thus, to protect one very feeble work, he undertook another equally inefficacious.

Thefe prodigious fortifications, now no longer vifible, were intended to protect Babylon, and a part of fouthern Babylonia, againft the inhabitants of the confines of Armenia and Mefopotamia. Thefe could not however have been very numerous; for their mountains were no lefs fterile than thofe of Ifauria; and perhaps the fame race ftill exifts, under the name of Satcblis, towards the Sengar. As the Greeks and Romans had the folly of attributing to Semiramis every thing of that kind beyond the Euphrates, they did not fail to give her credit likewife for the great wall of Media. Suppofing this to be fact, it would of courfe follow, that the Affyrians, who then trembled before a fmall nation of favages, were not in a ftate to alarm all Afia with their numerous armies. But let it be remembered, that thofe, who wrote this hiftory of Semiramis and the Affyrians, were not philofophers.

-Previous to arriving at the Van-ly of China, two walls were formerly feen to the weft of the Cafpian fea : they formed part of a chain furrounding almoft the whole of that extenfive portion of the globe, called by us Tartary, but known to the ancients by the name of Scythia. Although both thefe terms are very improper, it is fcarcely poffible to exprefs better a multitude of nations, almoft without exception Nomades and wandering.

Amidft the fandy Hircanian deferts, the canton of Margiania enjoys all the favors of nature. Alexander 
ander was fo much charmed with the beauty of this delightful fpot, that he refolved to found a city in its vicinity; and although death prevented him from executing his project, it was afterwards refumed by Antiochus, fon of Seleucus Nicator. Experience, however, foon proved the neceflity of protecting in fome way or other the cultivated lands from the ravages of the Scythians; and he therefore furrounded the whole diftrict with a wall fifteen hundred ftadia in length. As that meafurement cannot be calculated at lefs than one hundred and twenty miles, fo extenfive an undertaking is entitled to lome attention in our prefent refearches *. But when we add, that the town, founded by Antiochus, was afterwards repeatedly pillaged, and finally committed to the flames by the Tartars, it is almoft needlefs to obferve, that this bul, wark refembled all the others by its total inefficacy.

Under the forty-fecond degree of north latitude, the great wall of Ilak extended from Shabaleg to the extremity of the valley of Al/hafh, a diftance of more than twenty leagues. Little local knowledge is ne. ceffary to conceive that it was intended to prevent the robbers of Turkeftan from annoying the town of Toncat and its neighbourhood, which, in the fourteenth century, was cultivated like a garden, and interfected by a thoufand canals. Nature, fays Abulteda, is no-where more beautiful than in this charming fpot, covered with flowers and fruits $f$. But it

* Strabo, Geograph. lib. xi.

† Locorum omnium qua Dets creavit, amanif/rmus, fays the tranflator of Abulfeda, Defcript. Choraf. \& Mawaralnahre.

mult 
muft be owing to the vifits of the Tartars that the vicinity of that town is now defert. Some other confiderable cities of Mawar-al-nalor, fuch as Samarcand and Bochara, had likewife furrounded the whole of their cultivated territories by vaft walls.to a great extent. Agriculture was effaced wherever the paftoral hordes appeared. They made a practice of pillaging and deftroying, to enforce their maxim, that pofferfion cannot render lands a property. The fall of the empire of Tamerlane, who was very partial to Samarcand, occafioned the deftruction of all the beautiful provinces fituated beyond the Oxus, or Gihon. Nothing now prevents the Nomades from traverfirig them with their flocks; and the whole region contains only miferable wretches, who exift by mutual robberies. It is unaccountable that the Chinefe emperor, Kien-long, was not tempted to take poffeffion of fo fertile a country, when, in our days, he ad. vanced as far as Badakchan, and there terminated his expedition. This Tartar prince was erroneoully re. prefented in Europe as having extended his conquefts to the Cafpian fea; and Mr. Boyfen has inferted the fame miftake in his extracts from univerfal hiftory, al though Badakchan is more than one hundred and fifty leagues diftant from the Cafpian fea.

Of all the barriers oppofed $\mathrm{d} 0$ the irruptions of the Tartars we muft allow that the Chinefe wall is the greateft, and likewife the moft feeble, becaufe the ftrength of fuch lines diminifhes in proportion to their extent. How could men, incapable of defending a redoubt, think of forming fuch prodigi- 
ous lines, which, if penetrated in any one place, be. came totally ufelefs? In its origin, the Van-ly of China was very different from what it appeared afterwards. Some independent princes raifed walls in various places, to break the impetuofity of the Tartar cavalry, without confidering that a triple row of palifades would have proved far more effectual, as we find to be the cafe along the Zeang-tong. It has been faid, and believed in Europe, that the emperor Scbi-cbuan. di undertook and executed the whole work in the courfe of five years; but this is a vulgar report, unworthy of the fmallett degree of credit. Scbi-cbuan$d i$ was not yet born, when the princes of $T_{z i n}$, having fortified a part of the province of Chen-fis, were imitated by the princes of $T_{c b a o}$ and $T_{e n}$, who covered in the fame manner, but more ftrongly, the provinces of Cban- $\sqrt{2}$ and Pe-tcleli. The bad chronology and diforder of the Chinefe books will not allow us to fix the precife period when the firtt labors of that kind commenced there; but it is fuppofed to have been about three hundred years before our era *.

All the princes we have mentioned were really in. dependent fovereigns, who admitted no fuperiority even in the emperor. As they confulted only the fafety of their particular ftates, no general plan was purfued, and many interftices remained among the

* What Mr. de Guignes fays of the confruction of the Chinefe wall, in the Hiftory of the Huns, is not exact. He confounds the emperor Schi-chuan-di with another prince of $T$ zin, who reigned at a much earlier period. 
different ramparts: Yet the whole of this undertaking, however it may be confidered, tends to prove, that, under their reign, the ftate of population was flourifhing, and the government far more moderate than the oppreffive defpotifm of the Chinefe emperors.

The monfter Scbi-chuan-di, in defiance of all laws human or divine, deftroyed entirely thefe independent fovereigns, and he afterwards united the different works they had raifed againt the Tartars. This chain was uninterrupted, unlefs by groups of rocks, until it reached the borders of Chan- $/$. Although the great wall is generally computed to be five hundred leagues in length, yet it really does not exceed three hundred and forty; becaufe we cannot confider as fuch the branch extending weftward from $\mathrm{Chan}-\sqrt{2}$, where earth only is employed, without either brick or mortar, and the fides fo ill fecured that even cavalry can effect a paffage. Thus we find how much it falls thort of the idea generally received in Europe, where no copies have hitherto been obtained of the infcriptions faid to be found there. The miffionaries pretend, that in the province of Cban-tong likewife certain characters are difcovered on the fide of mount Tai-cban, which no perfon can explain : but fomething of the fame kind, feen on the rocks of Siberia, is not confidered as a monument of great antiquity *,

On

* Strahlenberg, Obfervat. With regard to the nine marble drums which Father Mailla fays he found in the college of 
On confidering attentively the Van-ly-czin, called hyperbolically by the Chinefe the Wall of ten thoufand $l y s$, it is evident, that a more ufelefs work was never reared by man fince the beginning of the world. The weftern Tartars, by turning from the ftrait road, and inclining towards thefortieth degree, could at all times enter China, withoüt perceiving either the terrace of Chen-fr, or the great wall. Marco Polo went with a troop of Tartars to Pekin, returned into Italy, and died at Venice, totally ignorant of that rampart. This made fome of the learned believe, that it had not been conftructed until after the thirteenth century; for, according to them, the filence of Marco Polo was of more weight than the depofitions of hiftory.

Experience has taught the Chinefe, that the Tartars cannot be reftrained, but by having well-difciplined cavalry to diffipate the hordes, when they begin to collect in their own country. Whenever they are allowed to unite and confpire, all is loft. The emperor Can-bi, who was himfelf a Mandhui, knew this perfectly well, and on the leaft noife of war, he invaded the territory of the Eleuths, and prevented great battles by a few fkirminhes. We have feen the emperor Kien-long imitating this conduct with equal fuccefs: confequently the Van-ly-czin is allowed to decay, as well as the wall of Corea; and in a few

Pekin, we have only to obferve, that the fuperfition of the Chinefe for the number nine might eafily have induced them to hew as many pieces of ftone in that form.

centuries, 
centuries, even the ruins muft difappear, or be traced with difficulty.

Ruffia, expofed nearly in the fame manner to the Tartars, had recourfe to fimilar means of reftraining them, at a time when, fo far from forefeeing its future grandeur, that nation almolt defpaired of fafety. By one of thofe events, almoft unexampled in hiftory, we know, that the Moguls, in the thirteenth century, extended their conquefts over the greater part of Afra and Africa. 'They fubjugated China on one fide, and Ruflia on the other, while the whole ancient continent refounded with the din of arms. In the year one thoufand two hundred and thirty feven, Batbi-Sain entered Ruflia, at the head of what was called the Gilded Horde, from being covered with fpoils. It was compofed of chofen men, who thought themfelves capable of extending in ten years their empire over Europe; but they were unacquainted with Germany, where their approach did not occafion fo much terror as the monks and pope particularly experienced in Italy. The conduct of BatbiSain was perfectly conformable to that of his coufin Koublai-Kan in China: he caufed feveral towns, and among the reft Cafan, to be built along the Wolga*; but, inftead of depofing the grand dukes of Ruflia, they were allowed, on paying a certain tribute; to preferve what was confidered an empty title, and the fhadow of authority. That unpardonable fault in politics ruined at length the fovereignty of the

* Verfuch einer Hiftorie von Kafan.

Tartars ; 
Tartars; who, befides, by requiring too great con' tributions in a poor country, excited fo many revolts, that their reign was nothing but continual war. On the other hand, they weakened themfelves by al. lowing fmall bands to feparate from the great horde; for the trunk, infiead of being fortified by fuch fuckers, was exhaufted. They loft fucceffively the kingdom of Cafan and Afracan; but they main. tained themfelves in the Crimea, where they afterwards acquired ftrength enough to undertake new excurfions, and even to fet fire to the city of Mofcow. This new difafter induced Fidor Janowitz, or rather his tutor Boritz Goudnow, to fortify the limits of the empire. Thefe works, apparently nothing more at firft than a great ditch, like that feen in Africa towards Thene, were in time converted into a continued bulwark, extending upwards of one hundred and forty leagues, from Toula, in the government of Mofcow, to Sibirifki, in the kingdom of Cafan. Ruffia muft have been ftill equally expofed to invafions, had not a prince at length fucceeded fo many Czars. Peter the Firft, inftead of repairing the ancient rampart, defeated the Tartars, and contented himfelf with hemming them in with the lines of the Ukrain, which remain unimpaired to the prefent day.

The great route of the barbarians, in their excurfions from what the ancients called Scythia, lay formerly between the Cafpian and the Euxine feas. This fuggefted the idea of clofing up all the defiles of mount Caucafus; and feveral veftiges of thefe walls 
are ftill found in the diftrict of. Souanis : but the moft confiderable work ever erected in that part of the globe was the wall of Colchis. That province, now fo defolate, received then all the merchandize of India. Sucl great riches, heaped up by the Phenicians and Greeks, who had vaft marts for commerce eftablinhed on the Phafis, irritated continually the covetoufnefs of a barbarous people called Acbas, or fome other term ftill more corrupt, by the French geographers. Their real name was Arucbafzi, and they are even fuppofed to fpring from the fame ftock with the Ajes, who, under the direction of Odin, penetrated into Sweden, according to northern fables. The Aruchafzi, however, always inhabited, and are ftill found between the mouth of the Don and the river Corax. They made their irruptions into the centre of Colchis, by paffing along the fhore of the Black Sea, and through the ftrait fomewhat beyond Petyunta. At length this paffage was clofed by a wall, fuppofed to be the ftrongeft ever reared by man, and therefore diftinguifhed by the name of Murus validus*. But the Awcbafzi, by directing their courfe to the left of this place, rendered its ftrength ufelefs; and another wall was therefore oppofed to them of more than one hundred and fixty. miles in length. It might indeed be confidered as one of the greateft undertakings of the kind, from being exceedingly well built throughout, and ftrengthened at equal diftances with towers. Yet Chardin could no

- D'Anville's Ancient Geography, vol, ii.

longer 
longer find even its ruins in one thoufand fix hundred and feventy-two, becaufe they were concealed among impenetrable forefts *

Colchis exhibits one very remarkable circumftance: extreme defpotifm has reduced the inhabitants to a favage ftate; and no other caufe is capable of producing that effect on a people once polifhed. Even the dreadful black peftilence, and all the ravages of the Huns, never occafioned any thing of the kind in Europe.

The ifthmus of the Taurica Cherfonefus was anciently fortified by a ditch called Tapbros in Greek; and afterwards by a wall in the place where we now find the lines of the Crimea. When the Cafpian barriers and thofe of Caucafus are added to the others already mentioned, we find that from the Borifthenes to the very extremity of the ancient continent, almoft the whole of Tartary has been in: clofed to the fouth by a prodigious chain of ram: parts. They were evidently erected with the inten. tion of reftraining the inhabitants of that region, who paffed them, however, as often as they thought proper. Although thole people, truly remarkable on fo many accounts, have had all the treafures of Europe and Afia in their poffeffion, yet they never transferred any to their own country; becaufe their leaders either perifhed amidft the torrent of their conquefts, or eftablifhed themfelves in the regions they had fubdued. The Romans, on the contrary, filled

* Chardin, vol. i. 
the capital of Italy with the fpoils of the univerfe; and what occafioned their weaknefs, was long the fupport of the Tartars, who are now in a more critical fituation than ever was experienced by any nation. Thefe unfortunate people can now fcarcely breathe, from being preffed together between China and Ruffia, the two greateft empires ever known on our globe. But the project of depriving them entirely of their horfes is impracticable; although it is faid to have been propofed by the Mandhuis to Kien-long, in order to render the Tartars for ever incapable of what they call brilliant expeditions.

Fortified provinces in ancient Europe were like. wife very numerous; and although they did not equal thofe of Afia in extent, they may at leaft be compared to them for their inutility. The Athenian colonies, fent into the Thracian Cherfonefus, under the conduct of Miltiades, clofed up the Ifthmus by a wall called macron teichos*. It reached from Pactya to Cardia; and in the Periplus of Scylax, the diftance between the two towns is laid down at forty ftadia. This work, having been partly ruined, was repaired and augmented by two branches, of which no traces can now be found.

After all the pains taken in ancient times to open the Ifthmus of Corinth, a plan totally oppofite was at length adopted, and Manuel Paleologus conftructed acrofs the neck a very thick wall, on which the fafety of the Greeks was fuppofed to depend. It might

* Herodotus, lib. vi. Pliny, lib. iv.

VOL. II, 
indeed have anfwered fome purpole, had they diffos vered more bravery, and made better difpofitions; but by concealing themfelves behind this rampart, they were prevented from fighting; and afterwards it impeded their flight. The Turks never made more prifoners in one day than when they forced the lines of the Morea; and although the Venetians were laborious enough to rebuild this barrier, it was foon after deftroyed a fecond time by the Ottomans. If the interefts of the Venetians required the Inthmus of Corinth to be fhut, the Turks had at leaft equal inducements to keep it open.

We have now to indicate the third macron teichos, or the long wall of Anaftafius, formed about twentyfive or thirty miles in front of Conftantinople. $\mathrm{ZO}$ naras fays, that it began at Selymbria*; but the ruins ftill feen, extend from a little beyond Heraclea to Dercon, and thus all the country between the Pro. pontis and the Euxine fea was inclofed for a diftance of fourhundred and twenty ftadia. An ecclefraftical writer, named Evagrius, infinuates that, behind this bulwark, a canal was dug to convey veffels along the continent from the one fea to the other. Conftantinople, fays he, formerly fituated in a peninfula, became in this manner an ifland + . The man however appears too injudicious for any dependance to be placed on his teltimony. Nothing could be more humiliating to the eaftern empire than this mode of defending its capi-

- Annal. in Anaftaf. Dicor.

t Evag. lib. iii. Suidas, and Nicephorus, lib. xxxix. 
tal againft the Bulgarian, Thracian, and Scythian cavalry. But Anaftafius had no horfemen capable of oppofing thofe of the enemy; and to preferve Conftantinople, he was forced to abandon all his Euro. pean territories, except the fmall fpot within the great wall. Every thing beyond it was at the difcretion of the barbarians, who had long before cleared the paffes of mount Hrmus; and the macron teichos no longer remained, when the Turks came to befiege Conftantinople.

Such, even in the beginning of the fixteenth century, was the ftate of that empire, which feems to have paffed through all the different degrees of decay; and no power was ever more regularly deftroyed. The fciences were loft firft; then the arts; military difcipline afterwards; and finally every thing that refembled force or conduct. But what never ceafed in thofe unfortunate times were enormous taxes, and religious difputes, which contributed greatly to throw all parts of the government into a diforder, hitherto unexampled in hiftory.

Some veltiges of a fourth macron teichos, ftill more extenfive than that of Anaftafius, are found in Bulgaria, near a town called $\dot{D}$ ryfta. But we can only learn, from the ftyle of architecture, that it muft have been raifed by fome Greek emperor, who oppofed this barrier in vain to the inundations of barbarians. It is not furprifing that fo little fhould be known of a monument of this kind in a favage region, when a total ignorance prevails relative to the wall of Valais. Many confiderable fragments of 
that fabric are feen ftill between the Rhone and Burgs berg; but no perfon can determine whether it was built before the days of Cæfar, or only in imitation of the rampart he employed fo ineffectually againft the Swifs : to me however the former opinion feems highly improbable.

Much confufion likewife appears in what has been written concerning the different works of this kind conftructed by the Roman emperors in Great Britain. Even the authors of that country are not all of the fame fentiments; but we thall endeavour, in a few words, to remove fome of the principal difficulties. Agricola, who knew the ifland perfectly well, was perfuaded that nothing was more neceffary than to keep poffeffion of a pafs, thirty-two miles acrofs, between the river Clyde and the Frith of Forth. Adrian, however, inftead of adopting this plan, chofe another place eighty miles broad; and it fhould be obferved, that the military mile is eftimated there at four hundred and twenty feet more than on the con. tinent. Thus the Romans began by conftructing a valluin of piles and fods, twice longer than was ne. ceffary. This rampart proved ineffectual : another, built by Antoninus Pius, was foon deftroyed; and a third, by Severus, thared the fame fate. At length, under the reign of Valentinian the third, Ftius, conceiving that all thefe works had failed from the nature of their conftruction, caufed a real wall twenty feet thick to be erected. But to prove how much he was miftaken, this rampart had not been finifhed five years before it was forced, firt at one place, and 
afterwards every-where. Buchanan affures us, that the ruins began to be found only in his day; and they are at leait fo far ufeful, that they now ferve to build houfes*.

By thefe and many other facts, we find that the origin of the power of the barbarians fhould be dated in the reign of Adrian, when the fortifications raifed againft them revealed the fecret of their force. In proportion as the Romans intrenched the limits of the empire, their military difcipline declined; and the fame effect muft have been obferved in every country inclofed by walls, without even excepting China. Thus all the bulwarks, raifed in Great Britain, were lefs effectual, as we have feen, than the judicious pofts and encampments of Agricola..

The Romans conftructed likewife a great wall in upper Germany, equally faulty, and as difficult to be defended as that of China. D'Anville's map of ancient Germany makes it begin oppofite Ober-Wefel; and after placing many interftices, the ftrongeft part is reprefented to have been at a fpot where the emperor Valentinian raifed fome works on the lower Necker. This arrangement, however, cannot be adopted; for the line was certainly uninterrupted, and equally fortified in its whole extent. Mr. Hanfelman, who has given a good defcription of this work in German, fays, that the tradition of the country ftates it as having been commenced in the reign of Adrian, and continued by his fucceffors. The laft branch, which Aretched towards the Danube, was added by Probus,

* Buchanan, lib. iv. Polydor. Virgil, libo i. 
as fome medals of that prince teftify beyond a doubt *: It began on the banks of the Rhine, oppofite Bingen, where the Romans had a fortified camp ever fince the time of Auguftus: thence it paffed into the county of Solms, forming an elbow to approach the Mein; and continuing through the foreft of Otton, or Odenwald, it croffed the county of Holach, touched the Necker, ftretched to Hall in Suabia, and taking the direction of Eichftadt and Weiffenburgh, terminated at Pfeurring in the territory of Ratilbon. Thus no paffage was left open in all the vaft fpace between the Rhine and the Danube; and, from the ruins ftill found, we have reafon to believe, that this rampart contained entire citadels, and numerous towers, ftrongly fortified. The Romans were obliged to give it fo winding a courfe, in order to cover the territories of fome nations, fuch as the Mattiaci, with whom they were frictly allied. But even by being conftructed in the fhorteft line poffible, it could not have anfwered the purpofe of reftraining the Catti, and other German nations, fyled wandering, becaufe, having no country, they fought one through. out the whole world. Marching with their flocks, like the Tartars, they refembled them alfo in the aftonifhing facility with which they changed the paftoral for a military life. Germany had anciently many fuch hordes, who wandered about conftantly,

- Dæderlein, Vorftellung des alten Ræmifchen Valli und Landwehr, iii. Abfch. The work of Mr. Hanfelman may likewife be confulted; the object of which is to inquire how far the Romans had ever penetrated into Suabia, and high Germany. 
and emigrated frequently. The fettled cantons had no other means of defence in thofe days, againt unexpected attacks, than by furrounding themfelves with vaft deferts; and this method, ftill practifed in the time of Julius Cæfar, would have kept them always barbarians. But afterwards the Germans, having procured better infruments for cutting down the woods, and digging the earth, fortified themfelves againft each other by works called Landwebr. The idea of this kind of rampart is fuppofed to have originated in Gaul; although it was generally practifed among all nations, when they began to cultivate the earth regularly in thofe countries, where their neighbours continued to be wandering.

It will be fufficient here juft to mention a vallum Romanum, extending from Widdin to Little Waradin, and fome other mounds of the fame kind, conftructed by the Goths, who, of all the barbarians at that time, inclined molt to civilization. In the north of Europe, we find the Danewerck, raifed by the Normans, when they began to be known by the name of Danes. To prevent the incurfions of the Saxons into Jutland, they endeavoured to thut up the paffage by a terrace, extending to the fhore of the Baltic; and on this very dike, Waldemar the Great conftructed a wall, which is lefs injured at the prefent day, than could well be expected.

Such is the hiftory of the greateft and moft ufelefs works ever reared by man on the furface of the ancient continent. 


\section{THIRD PART.}

\section{SECT. VII.}

RELIGION OF THE EGYPTIANS,

THE religion of ancient Egypt is a real abyfs, 1 where many writers have been fwallowed up in attempting to found its depth. Such numerous and different fuperftitions, which fometimes are altogether inexplicable, can never admit of being reduced to any particular fyftem.

Van Dale had reafon to believe, that the facred animals were inftituted in Egypt for the purpofe of divination. Yet, if we except one obfcure paffage in Elian relative to crocodiles, nothing is known with certainty of any other oracles, than thofe of the bull Apis, which comprehended every thing, although they were originally confined to the overflowing of the Nile. On this point the Egyptians have at all times teftified the greateft inquietude, without confidering that other animals were as ignorant of the matter as themfelves. The crocodiles are faid to depofite their eggs beyond the reach of the inundations; but this is a vulgar opinion, adopted only in fome towns fituated on the branches of the 
Nile. Naturalifs believe that the hippopotamus gives furer indications; becaufe the inhabitants pretend to have obferved that when, previous to the floods, it frequently appears on fhore, the river always rifes fufficiently afterwards to water the lands. The Copts, however, at this day employ no animal in their prognoftics on the ftate of the Nile; and yet their ceremonies for that purpofe, during which even the Turks affift at mafs, are fully as fuperftitious as the mode of interrogating the bull Apis. When that animal refufed to eat, the omen was not lefs fatal than the abftinence of the facred chickens, which were confulted by the Romans on great affairs, while matters of little confequence could be decided by crows. If Juvenal had been judicious enough to reflect on this, he would not have written his fatire on the Egyptians; for the difference between fuppofing a calf or a chicken acquainted with future events is furely not very material.

By all that has been collected in this Section, refpecting the worfhip offered to fcarabees, it appears that they likewife ferved for auguries; and we muft fuppofe thofe infects at leaft as well informed in fuch matters as the priefteffes of Delphi; for whom Plato teftified fo much regard. This was in confequence of his being perfuaded that no civilized nation can have a reafonable religion; and the fame fentiment feems to have prevailed among all the legillators of antiquity.. We thall fee prefently, that this falfe and whimfical opinion was founded entirely on the fuppofed danger of making innovations in the religious 
practices, which had been received from the favages of the country, or, as Plato ftyles them, the indigenous inhabitants.

The greater part of the religious ceremonies of the Egyptians came from the favages of Ethiopia, as Dicdorus fays in the moft unequivocal manner; and the fact is of a nature not to be doubted. Yet no perfon has hitherto ever undertaken to feek in Ethiopia the origin of a worthip, evidently invented there. Mr. Jablonki was perfectly capable of making. fuch refearches, the refult of which would have been. infinitely more fatisfactory than the conjectures he has hazarded, and the contradictions he could not: avoid.

At the article $P b t b a$, he defcribes the Egyptians; as atheifts, whofe fyltem refembled too exactly that of Spinofa, for any perfon to be deceived, who had: the leaft penetration.

At the article Cnepb, or Cnupbis, he changes the fame Egyptians into deifts, who admit of an intelligent Being diftinct from matter-the Sovereign of Nature.

Mr. Jablonfki, who had much good fenfe, and ftill more erudition, would furely have reafoned in a different manner, had he been lefs connected with La Croze, who, by the confeffion even of his panegyrift, became a mere vifionary in the decline of life, without any figns of the little judgment he formerly: poffeffed. That man, bred a monk, flattered him. felf greatly on his penetration in difcovering atheifm every-where; and he fancied he had found it in the wretched 
wretched Latin verfes compofed by a fool, called Jor. dan le Brun, who was committed to the flames by fome villains in Italy. It is madnefs, or at leaft imbecility, to accufe whole nations of atheifm, when they. produce a few bad metaphyficians, who by means of certain fubtilties lofe themfelves in a cloud of ideas; and their abfurdities difcover impertinent reafoners, rather than atheifts ferioufly determined on maintaining their opinions. Thofe, who adopt fyftems without knowing the objections they may encounter, would do better to remain within the limits of incer. titude.

Ancient hiftorians and geographers unfortunately give us very little information concerning the Ethiopians. Yet the few notions, we have been able to collect, are fufficient to explain feveral difficulties, and render the way lefs obfcure. In the firft place, it appears certain, that, with regard to religious matters, they always remained clofely connected with the Egyptians. They came annually to carry the thrine of Jupiter Ammon from Thebes to the limits of Ethiopia, where a folemn feaft was celebrated, which certainly gave rife to the fingular tradition of the gods coming to eat at the Heliotrapéze, or the Table of the Sun*. When Homer affures us, in the Iliad, that Jupiter went frequently into Ethiopia, to affift at a great feftival, we may fuppofe the poet informed of this ceremony $t$. Herodotus has erred in placing the Table of the Sun at Meroe, although Solnus fup.

* Diodorus, lib. ii.-Euffat. in Iliad. + Lib. i. 
pofes it to have been fill more towards the fouth. The whole proceffion required, as we are told, only twelve days, in going and returning by a different road from that which extended along the eaft bank of the Nile; and it is impoffible to perform the jour. ney in that time by the fhorteft way from Thebes to Meroe. The latter place had, however, a temple dedicated likewife to Jupiter Ammon*; and this fact tends alfo to prove, that the religion of the Egyptians and of the Ethiopians was originally the fame. Among the former, indeed, fome changes had been introduced in the courfe of many centuries; and the moft important of all related to the immo. lation of human victims. Heliodorus, although a great admirer of the Ethiopians, admits that they facrificed boys to the Sun, and girls to the Moon $f$. The colony fent by them into Egypt, continued likewife to flaughter ftrangers, or men with red hair, on the tomb of Ofiris, or the ftones confecrated to the Sun; and women were moft probably facrificed to the Moon, in a fmall town called by the Greeks. Ilithya. Some remains of that place are ftill found on the right bank of the Nile, near a fpot known by the

* Plinius, lib. vi. cap. 29 .

+ Ethiop. lib. x. Heliodorus fays, that the Ethiopians facrificed Atrangers only who were taken in war; and although the gymnofophits reprobated fuch facrifices, the people perfitted in offering them. The Greeks imagined that the Egyptians immolated red-haired men in the town of Diana, or Ilithya: but, in my opinion, it is more probable that they facrificed women.

name 
name of $E l-K a b$, not more than twenty-four leagues from the confines of Ethiopia.

Mr. Jablonfki was therefore wrong in fuppofing, that thefe atrocities had been borrowed from the thepherd Arabs. They were at length totally abolifhed in the reign of Pharaoh Amafis; while the famous law for burning heretics alive, was not repealed in England until the time of Charles II. The hifo tory of Egypt has never fince afforded any inftances of that nature: but in Ethiopia it was more difficult to reform religion, becaufe the civil laws had lefs power over the people, who were frequently difperfed either in hunting, or wandering with their flocks in fearch of pafture.

The firt gymnofophifts of Ethiopia moft probably were nothing more than wandering priefts, like thofe ftill known in Africa by the name of Marabuit. That word, literally tranflated, fignifies Clbild of the burning reed; either becaufe thofe impoftors fome. times burn their victims with reeds, or perhaps in alIufion to their pretending to vomit fire, while they conceal kindled tow under their garments. An example of this was feen in one thoufand feven hundred and thirty-one ; but executed in fo awkward a manner, that negroes only could have fwallowed the deception. When a nation has no other than wander-. ing priefts, it is eafy to conceive, that among the numberlefs different fuperftitions introduced there, fome muft of courfe be contradictory; becaufe opinions not being reduced to any body of doctrine, each juggler endeavours to advance his own. Count 
Boulainvilliers fays, that among people like the fhepo herd Arabs, the idea of a God Creator muft have been longeft preferved in all its purity *. But he knew nothing at all of the ancient Arabs, concerning whom Sale has procured explications, which prove that their notions of the Divinity were very degraded. This indeed muft have been the cafe, becaufe each tribe multiplied the number of Fetiches and $\mathrm{Ma}$ nitous, of which the facred animals of Egypt and Greece are the remains: For it might be proved, if the thing appeared of fufficient confequence, that the Greeks were likewife greatly attached to the worhip of animals: they revered, to a certainty, about twelve or thirteen different kinds, without including the weafel of Brotia.

The fpirit of the gymnofophifts did not begin to be developed until they were united in a fedentary body, or college, principally ftationed at Meroe. They then began to apply themfelves to ftudy, and place fome order among the Ethiopian hieroglyphics: but unfortunately the treatife written particularly on that fubject, by the philofopher Democritus, is entirely loft $t$. No perfon thould be tempted to credit fuch extravagant praifes as thofe lavifhed by the Roman writer Philoftratus, on the gymnofophifts Yet it is polfible, that in laboring to compile their hieroglyphics, they might have invented the fyllabical alphabet, ufed at this day in Abyffinia and Nubia,

\footnotetext{
* Life of Mahomet. † Apud Laertium.
}

$\ddagger$ In rit. Apollon. lib. vi cap. 6. 
whither it could not be brought from any other country*. That difcovery was the more interefting, as without it literal characters could never have been invented. It is a ftrange folly in Plato to accufe the priefts of Egypt of having injured irreparably the fciences, by inventing the art of writing. According to him, it tends prodigioufly to weaken the memory; and Julius Cæfar feems inclined to fupport this prejudice, when fpeaking of the Druids, who furely never got any thing by heart but abfurdities.

Although fome paffages are found in Diodorus and Strabo, relative to the opinions of the gymnofophifts concerning the Divinity, yet it muft be confeffed that they are very obfcure. They feem founded entirely on the authority of fome Greek merchants, who about the time of Ptolemy Philadelphus began to penetrate into the centre of Africa. We know no. thing more with certainty, than that they acknowledged the exiftence of a God Creator, incomprehenfible by his nature, but vifible in his works, which, according to them, are equally animated with the divine fpirit. From this doctrine proceeded the fymbolical worfhip adapted to the genius of the Africans, whofe ardent imagination required to be fixed by palpable objects like the Fetiches, and their anxiety concerning futurity, calmed by auguries. The Greeks and Romans confulted the oracles every in-

- Herodotus obferves, in his fourth book, that the Ethiopians ufed two very different charaeters. The firlt confitted of hieruglyphics, from which thofe of Egypt were copied : the fecond we may fuppofe to have been a fyllabical alphabet. 
ftant merely from habit; but among the Africans;. that cuftom feems to have been a phyfical want peculiar to warm climates; where the minds of the common people are extremely weak and impatient. In Europe it is remarked, that women in general are much more eager after predictions than men; while philofophers, undifturbed at the idea of what may happen, correct or fupport bad fortune.

Many natural reafons explain why oracles have ceafed in fome places of ancient Europe and Afia; but they can never be abandoned in Africa. Two are known at this day on the weftern coaft, which are as famous as ever could have been that of Delphi. By an unpardonable ignorance of modern hiftory, both Van Dale and Fontinelle have been led to admit, in favor of their adverfaries, that all oracles are now really filent. This fallity, however, is demonftrated by the narratives of travellers, who are now living; and particularly by Romer.

When Pliny and Solnus fay, that fome cantons of Ethiopia had elected a dog for their king, it can only be underftood, that they rendered worfhip to that animal, of which we have feen many examples among the Egyptians their defcendants. The information of the ancients concerning the interior of Africa, was certainly more extenfive than ours; but on the other hand the coafts are much better known to us; and all the nations there, without exception, revere ferpents. The inhabitants of the kingdom of Fudbac worhip one fpecies, which feems to have no noxious qualities; and it is even fuppofed to deftroy 
fome finall black-colored adders, faid to be venombus : but other negroes have converted real vipers into feticles, although their bite almoft invariably "occafions death. In general, the adoration paid to rerpents is founded on the fear naturally entertained by inankind for thofe reptiles : fuch as are dangerous, it is fuppofed, fhould be conciliated; and the others feem to merit a peculiar diftinction, as if a genius, friendly to humanity, had taken care to difarm them; and this clafs has principally been ufed for prognoftication. The omens were confidered favorable when the Ifiac ferpents tafted the offering, and dragged themfelves flowly round the altar: But it muft be obferved that fome of thofe reptiles attach themfelves like dogs to their mafters, and learn different tricks, which are never after forgotien: thus we may, with fome certainty, fuppofe, that the ferpents of Ifis were taught to obey the voice or geftures of the minifiers. The Cneph, or divine goodnefs, was reprefented by an innocent adder; and ftrength or power, by a viper. The priefts of Ethiopia, as well as thofe of Egypt, wore the figure of the latter coiled up in their bonnets of ceremony; and we have aiready had occafion to obferve, that the diadem of the Pharaohs was likewife ornamented with this emblem*.

The worfhip rendered to ferpents was not confined to particular towns of Thebais and Delta; for Elian

* Sacerdotes REthiopam et Rigyptiorum gerunt pileos oblongos in vertice umbilicum babentes, et Jerpentibus, quos Ajpitles appeliant, circumvolutos. Diod. lib. iv.

VOL. II. 
aflures us, that they were kept in all the temples of Egypt * : this feems the more probable, becaufe it was one of the nolt ancient, or perhaps the firft fuperfition of the inhabitants of Africa, where the largeft adders were carefully collected for the temples of Serapis : fome of thofe brought by the Ethiopians to Alexandria were twenty-five or twenty.fix feet in length; but they are found of more than twice that fize in Senegal.

The want of documents prevents us from entering into further difcuflions concerning the particular devotion of the college of Meroe : we know, however, that it terminated in the moft fatal manner, from hav. ing conftantly oppofed the progrefs of defpotifmthat ancient malady of fovereigns. Ergamenes, the tyrant, who was cotemporary with Ptolemy Philadelphus, and a Greek by origin, is faid to have caufed all the gymnofophilts to be maffacred in one day; and this threw that part of Ethiopia into a ftate of defolation, whence it has never fince recovered. Some ruins only are found of Axum, Pfelches, and Naphthe, where fome years ago the Jews, it was faid, intended to form a ftate independent of the Turks and Abyfinians. This report, however, has not been conitirmed; and indeed they are to be confidered as not only incapable of executing, but even of meditating fuch a project, for they know no other heroifm than ufury.

The philofophers of Ethiopia, like thofe of Egypt swolt probably clothed their knowledge in allego-

- De Nat. Animal. lib: x. cap. 31. rics: 
fies : on this muft have been founded the fable related by Plutarch, concerning fome towns and villages fituated near the ifland of Elephantis, which Pharaoh Amafis promifed to cede to the king of Ethiopia, if his gymnofophifts fucceeded in explaining certain enigmas. The Ethiopians, he adds, hazarded fome of their territories on the fame condition : but although we read other fuch ftories in the writings of the amplifier Jolephus, and in the life of $l E$ fop, compofed by a fool called Planudes; we muft not be tempted to believe that the fovereigns of antiquity were fo eafily difpofed to fport with their dominions : Egypt in particular was too fmall to be difmembered for an enigma, particularly by fuch good neighbours as the Ethiopians, who never attempted to turn afide the courfe of the Nile, concerning the poffibility of which more fhall be faid in the Section on Govern. ment.

After what has already been obferved, it would be fuperfluous to refute the many different fyftems propoled, ever fince the days of Ifocrates, on the origin of the worfhip rendered to animals. We find that the Egyptians, inftead of being the inventors, had brought that cuttom with then fron Ethiopia, where it feems to have originated with the ferpents, and the fmall bull, fuppofed to be the bubalos of naturalits. This animal, the dwarf of its fpecies; has horns refembling thofe of the moon; and the imagination of the Africans has frequently been ftruck by fimilitudes much lefs obvious. The colony of Ethiopians, who took poffeffion of the valley of the Lower Nile, in- 
ftead of renouncing, became more than ever attached to fuch fuperititious practices, when they remarked the utility of the cat, weafel, ichneumon, fparrowhawk, vulture, fcreech-owl, ftork, and ibis. It was abfolutely neceffary to put fuch animals under the particular protection of the law; otherwife the country would have been altogether uninhabitable. The Turks, who do not pretend to be idolaters, are as careful in preventing the ibis from being deftroyed as the Greeks and Romans. Whatever may be the religion of thofe who thall in future poffers that country, they will always continue to refpect thofe animals, fo juftly named the purifiers of Egypt.

It has always appeared unaccountable to the ancients, as well as to the moderns, that fome towns fhould have adored crocodiles. Cicero is the only perfon who fuppofes that this was in confequence of their utility*; but he would have been much embarraffed to explain in what confifted this advantage, fo inconceivable to much more able naturalifts. In the year one thoufand feven hundred and feventy, having been particularly engaged in fludying the topography of Egypt, it firft occurred to me that Coptos, Arfinoe, and Crocodilopolis the fecond, the towns molt remarkable for the adoration of crocodiles, were all fituated on canals at fome diftance from. the Nile. Thus by the leaft negligence in allowing. the ditches to be filled up, thofe animals, from being. incapable of going far on dry land, could never have

* Poffern de ichnesmonum utilitate? de crocodiloriam, de feliuna dicere; fell nolo efe longus. Cicero de Nat. Deorum, lib. i. cap. $3^{5}$. 
artived at thofe three places, where they were conidered as the fymbols of water fit for drinking and watering the fields, as we learn from Elian, and more particularly in a paffage of Eufebius*. As long as this worfhip was in vogue, the government might remain affured that the fuperftitious would not neglect to repair the canals with the greateft exactnefs. In the fame manner every dependance could be placed on the Oxyrinchites for preferving the great canal, now known by the name of Kalitz il Menhi, on which depended the arrival, among them, of the facred fin called oxyrinchus. Two other towns, in. deed, Crocrodilopolis the third, and Ombas, had likewife their crocodiles: Mr. d'Anville hefitates in fixing the pofition of Ombos, but he fhould have placed it further inland, towards the foot of the Arabic heights, for we know that the inhabitants had dug valt ditches for watering their plantationst. It is therefore eafy to conceive why the people of the Arfinoite Nome, or the province of Feium, had a crocodile called Sucbu, or the juft, ornamented with golden ear-rings and bracelets, as we learn from Strabo. That lizard was to them not the emblem of Typhon, as fome have believed, but of the water on which their exiftence depended, fo entirely, that they

* Per bominem crocodilo impofitan naven ingredientem; navemque fignificare motum in bumido, crocodilim vero aquam potui aptann. Eufeb. Præpar, Evan. lib. iii. cap. I i.

+ Aflian de Nat. Animal. lih. x. cap. 21. The fatuation of Crocodilopolis the third is not known; but from what we know of the other towns, which had the fame name, it cannot be fup. pofed to have been on the banks of the Nile. 
could not have fubfifted fix months if the canals to. wards Illabon had been neglected. It is probable that the Arfinoites endeavoured to draw fome au. guries from their facred crocodiles, relative to the future overhowing of the Nile, becaufe they were ftill more interefted in that event than thofe who lived in the towns along the river.

We have already, in another part of this work, attempted to explain what might have been the ob. ject of the worthip offered to the fquill, or fea-onion, by the people of Pelufium and Cafium, fome of whom were attacked with a fwelling of the tympanite kind, and a delirium called typhomany, which, as the term denotes, was an Egyptian diforder. It is furprifing that faint Jerome, when fpeaking of this extenfion of the inteftines, did not perceive that it produced thofe effects, which he endeavoured to render ridiculous*. It would certainly have been more reafonable to pity unfortunate people; labouring under natural infirmities, produced by the fogs of the lake Sirbon, which are faid to be no lefs noxious than thofe of the lake Afphaltis, or the Dead Sea, particu. larly during the heat of fummer. Mr. Pococke, who vifited the latter in April, found himfelf afflicted with a weaknefs of ftomach, and an exceffive dizzinefs, from having neglected, as he was told by the people of the country, to ufe fufficient precaution againft the vapors. When the Arabs pafs near that vaft river, where the water is fo thick that it prevents

* Taceam de formidolofo E borribili cepe, E' crepitu ventris in: fatti, qui Peluffaca religio eff. In Ifai, lịb. xii,

aṇimal 
animal bodies from finking, they cover their mouths, and breathe only through the noftrils.

Among the fuperftitions of the Egyptians, fome at firt fight feem unaccountable, fuch as their devotion to the fhrew-moufe: it was revered in the town of Airibis, and embalmed after death in a fepulchre for the purpofe at Butos, although the diftance between the two places was more than fifty miles. The eyes of that little animal being almolt as much concealed as thofe of the mole, Plutarch pretends, that the Egyptians, believing it to be entirely blind, fancied in this fome fimilitude to the diminution of light in the waning moon, and to the Atbor, or the attribute of the Divinity perfonified under that name, which was, in fact, the incompre- henfibility of God, compared with the darknefs of night and of chaos. Bur before any fuch forced and complicated references were invented, fome much more natural property muft have been difcovered in the fhrew-moufe. It has always appeared to me that the Egyptians, like the Greek naturalifts, confidered that animal as belonging to the clafs of weafels*, which received equal protection with the ichneumons. The latter, we know, were confecrated to the Egyptian Hercules, who was the fame divinity with the Hercules of Thebes, in Beotia ; but as Greece pro-

* The Greeks gave the name of weafel-monfe to the fhrewmoufe, becaufe they conceived it partook of the nature of both thofe animals. This was certainly a more proper term than that of mus-araneus, - which was ufed by the Latins, for it had fome refemblance to the wealed and none at all to the fpider. 
duced no ichneunons, the Thebans made no difficulty of fupplying their place with weafels; and although Greeks, fiys Wlian, they are not lefs ridiculous for adopting fuch all abfurd devotion*. The inveteracy of the weafel towards rats and mice made the Egyptians place that animal under the protection of the law; and funding fomething of a refemblance, however trifting, in the fhrew-moufe, they were led to. imagine all the fymbolical doctrine already mentioned.

Some facred animals poffeffed only enigmatical and augural properties, in whatever manner they are confidered: fuch was the fcarabee, dedicated to the fun, and very different from the ugiy infect mentioned by Pliny. From the defcription given by Orus Apollo, who fays it refembles the fparkling luftre of the eye of a cat in the dark, we may conclude that the Egyptians had taken, for the fymbol of the fun, the great golden fcarabee, called by fome the cantharides. This infect is frequently feen in gardens, where it feeds on ants and fmall worms; when the light falls directly on the fhield of its wings, it has perfectly the appearance which the Latin tranflator of Orus Apollo cails, radiis infignita: The. other fcarabees of Egypt were the monoceros, with one horn on its corfelet, and the horn-beetle with two, which it fhuts like pincers. All the fuperfitions, relative to thefe three infects, were confidercd as very ancient; and they appear to have been common to the Ethiopians, and other inhabit:

* Theberni, quamvis natione Grxci, rifu funi obruendi; qui muftellam, zut cudio, religioge colunt. De Nat. Animal. lịb. xii. cạp. 5 . 
ants of Africa, even before ligypt was inhabited *. Some traces of the fame worfhip are found, not only in the holy cricket of Madagalcar, but likewife among the Hottentots, who, as we read in the General Hiftory of Travels, look with veneration on the perfons over whom either the fcarabee with golden rays, or the horn-beetle of the Cape, chances to pafs, becaufe they confider it as a fortunate omen. What appears fill more furprifing is, that the fame prejudices, with regard to the fcarabse, have been introduced into Europe, where it is called by the vulgar, the Fly of the Lord. This fuperftition could not have proceeded from the writings of St. Ambrofe, becaufe they are never read by the common people, who mult, therefore, be ignorant that he has frequently compared the Mefliah to a Scarabee, without leaving us even the thadow of a conjecture on what fuch a Atrange comparifon could be founded. In many places of Europe the fong of the cricket is likewife confldered as propitious; and many perfift in preferving thefe infects, although their thrill and monotonous noife is almoft infupportable, when they become very numerous, Whatever may be the devotion of Europeans towards crickets, it does rot equal that of the Africans, who make a living by rearing them; and the rich would think themfelves at enmity with heaven, if they did not preferve whole fwarms in ovens, confructed exprefly for the purpofe. It hould be conftantly re.

- Scarabces are, even now, feen fculptured on ftones in the royal \{epulchres of Bibcn-el-Moluk. We have already oblerved that thefe monuments arc more ancient than the pyramids.

membered, 
membered, that the minds of the lower clafs of people are liable to be forcibly Aruck with trifling matters. Not many years ago the French peafants began to render a kind of religious worfhip to the chryfalis of the catterpillar, found on the great nettle, becaufe they fancied it revealed evident traces of the Divinity. M. des Landes affures us, that the curates had even ornamented the altars with thefe maggots; as grafshoppers and canary fparrows are kept in cages in Spain to fing during the celebration of mafs** If the imagination of man can be carried to this point in our temperate climates, can any perfon be furprifed that the Africans, whofe fancy is exalted by the fire of the atmolphere, fhould difcover fome refemblance between the horns of the moon and thofe of the bubalos; or between the horn-beetle and the zodiacal Bull?

In the monuments defcribed by Montfaucon and Count Caylus, the Egyptian women are feen feeding the fcarabees on tables, or altars. This probably reprefents the real mode of drawing auguries from thofe infects, which were treated nearly in the fame manner with the chickens at Rome, in the ceremony of what Cicero calls, the tripudium, and terripavium, in his fecond book on divination. Hawever whimfical thofe practices may appear, they do not equal the mode invented by the Chinefe for confulting the tortoife, which is one of their greateft oracles. That fu. perftition furely was, not derived from the Egyptians,

* Recueil des differentsTraités de Phyfique, and Bảrettï setter on Spain. 
for the tortoife has never been even mentioned among their facred animals; yot all attempts to afcertain exactly the total number, have been hitherto ineffectual; and the refearches of Mr. Blanchard, inferted in the ninth volume of the Memoirs of the Academy of Infcriptions, are altogether imperfect and inconfiftent. We thall, however, indicate here nearly all that can be known of that matter from ancient authors; and, after having fpoken of the objects of fymbolical worthip, we fhall endeavour to develope the real fentiments of the Egyptians concerning the effence of the Divinity.

In a burgh, fituated at the northern extremity of the lake Mareotis, a facred bull was fed ; and although many other towns of Egypt practifed the fame devotion, yet the names of Hermonthis, Heliopolis, and Memphis only, are recorded. The reputation of the bull Apis eclipfed that of all the others, as foon as the court of the kings was transferred to Thebes; but in other refpects the Egyptians had as great veneration for the environs of Memphis as for thofe of Abydos. The learned cannot agree on the term fixed for the life of Apis : Plutarch pretends that he was drowned at the age of twenty-five years; and this, according to him, agreed with the number of characters contained in the Egyptian alphabet : but Mr. Butter, who fucceeded in finding out the Egyptian letters, by ftudying the fillets of the mummies, afferts, that they did not exceed twenty-two. It is probable that Apis was deftroyed as foon as his appetite and vigour flagged under thepreffure of age, becaufe in that ftate he could 
not give favorable auguries, the only fervice required of him by the people. It may be prefumed that the pullarii, attached to the Roman legions, prevented, in the fame manner, the facred chickens from living beyond a period prefcribed by certain rules of the arufpices. The Egyptians drew prognoftics alfo from the voice of children, who fang and played in the proceffion of Apis, or at the door of his ftall: Mr. Jablonfki obferves, that the oracle of the Jews, known by the name of $\mathrm{Bat}$-Kol, or daugloter of the voice, appears to have been the fame with that of the children in Egypt, who became prophets before they were men.

Several towns of that extraordinary country, fuch as Momemphis, Chufe, and Aphroditopolis, kept facred cows; but the common burying-place of thofe animals was at $\Lambda$ tharbechis, whither their bones were brought in boats. Cats received almoft exactly the fame treatment; it was unlawful to kill them in any part of the country, and when dead they were buried at Bubaftus. Bears had likewife their fepulchre, pro. bably at Papremis; a town dedicated to Typhon, of the evil principle, who was fuppofed to be calmed by having workhip rendered to the hippopotamus, the true fymbol of the typhonic fpirit. That animal, fo far from coming at the prefent day to Old Cairo, never defcends below the cataracts of the Nile, and it was by mere chance that one was taken at Damietta, after having loft itfelf in following the courfe of the tiver, In ancient times the race mult have been much more numerous than at prefent; and we find lions 
and tygers diminining in the fame manner. This is likewife fuppofed to be the cafe with the crocodiles of the Nile, for they certainly never fhow themfelves now in thofe places, where Seneca fays they were very abundant in his time*.

It feemed, indeed, as if the Egyptians had intended to make their country the receptacle of beafts; and yet they did not poffers fo many different kinds as Cicero intimates. In. the firlt place, thofe ufed for burden, like the dromedary, the camel, and the elephant, were excluded, as well as all folipedes; for the horfe was never admitted among the feticbes, and the Egyptians always difcovered a great antipathy to the afs. This has been afcribed to its kin, which is generally red in that country, where all animals of that color were fuppofed to contain the eflence of fome diftemper: in fact, the Egyptians conceived it to be incompatible with a good conftitution; and although their naturalints have been turned into ridicule on that account, even by M. Montefquieu, their opinion is certainly more and more confirmed, at leaft with regard to cattle.

It is remarkable that the fame animals were generally confecrated in two different towns; as we find to have been the cafe with lions, dogs, rams, and wolves. IElian pretends that the inhabitants of the great Lycopolitan prefectory took care to pluck up entirely that fpecies of aconite, vulgarly called wolf'sbane, lef it thould injure any of the objects of their

- Nat. Queft. lib. xiv. cap. 2. It muft, however, be fuppoled. that Seneca was well informed. 
veneration. 'This ftory, however, is truly ridiculous; when we reflect that the Lycopolitans never permitted the wolves to run at liberty in their provinces: thofe animals did not exceed in fize the common houfe-dog; and fome well-preferved mummies have proved their characteriftics to be very different from what they are defcribed by Herodotus.

The weafel was revered principally in Thebais; the ichneumon, or the rat of Pharaoh, in the towns of Hercules, fuppofed by fome gecrraphers to have beer three; the Shrew-moufe ai Atribis and Buto; the antelope at Coptos; the bick-goät at Mendes, Thmuis; and probably alfo at Panopolis : the otter, although never tamed, was apparently privileged throughout the whole country. The two towns of Mercury had cynocephali, or papions, which, as well as the monkey Cebus, feenin the Babylon of Egypt, about two leagues above Memphis, were broight from Ethiopia.

Epiphanes fpeaks of a chapel where ravens were fed *; but this muft have been a tomb near the lake Maris, which, according to the tradition of the country, contained the body of a bird of that fpecies, employed by an ancient king in carrying letters. No other conveyance of letters was known in Egypt than by means of pigeons; and the origin of this expedient is loft in the night of time: we find it mentioned as a very common thing in the verfes of Anacreon, who practifed that manner of fending billets, which were no doubt worthy of being

\section{- In Arcot. tom. ï}


carried by the favorite birds of Venus*. It is not amifs to obferve here, that the obfervations in Mr. Mallet's work, relative to the cuftom of employing pigeons in literary correfpondence, is extracted from fome Arabic authors, who have evidently exaggerated; and their teftimony befides is of no weight, with re. gard to the diftant periods to which we now allude. Diodorus Siculus informs us, that the government of Egypt fent letters to every town in the whole kingdom, announcing the increafe of the Nile-the meafurement could only take place at the three Nilometers; and as pigeons were fo numerous, from their being the chief food in times of the plague, it feems natural that the Egyptians thould have preferred them for conveying fpeedy information; befides, it was difficult for thofe meffengers to lofe their way there, becaufe, in proportion as they afcended in the air, they faw themfelves furrounded by the fea, and vait deferts of fand.

Two towns, known by the name of Hieracopolis, fed fparrow.hawks; but a different fpecies, brought from Ethiopia, and not hitherto afcertained by naturalifts, was confecrated in the temple of Phyle. The eagle was revered in Thebais, and the fcreechowl at Sais; the vulture, the ibis, the tadorne, the ftork, and the puet, were univerfally facred; although they had no temples; while Arnobus affures us, that fome chapels were dedicated entirely to fcarabees $\uparrow$.

* Ode ix.

+ Arnob. adverfus. Gent. lib. i. 
The perch, or the filh called the variole, was held in great veneration at Latopolis; the carp at Lepidotum, a town of Thebais; the pike at Oxyrinchus; the fea-bream, or reddifh-fparus, at Syene; and the meotis in the inland Elephantis: but the charac: terifics of the latter are not known, any more than thofe of the phyfa, which feems to have anfwered likewife fome fuperftitious purpofes. The Greeks, however, were greatly miftaken, when they confidered. the eel, becaufe not eaten by the Egyptians, as belonging to the facred filhes $:$ many things prohibited by the dietetic regimen muft not be counted among the number of fctiches; but worhip was certainly paid to ferpents at Metellis, in Lower Egypt, and probably at Terenuthis. All the temples contained, indeed; differ ent kinds of reptiles, the molt remarkable of which was the horned adder, revered in fome parts of Thebais; and, according to all appearances; in the ifland of Elephantis, as well as at a little town called Cnuphis, fituated towards the twenty-fifth degree.

The hitory of the facred plants of Egypt has always been very obfcure; and we only know that great veneration was teltified there for the nymphea, the poppy, the olyra, the papyrus, the fquill, the abfynth of Tapoforis; and, as Vefling fays; wild muftard. To thefe were added, the perfea, different kinds of palm-trees, and the acacia, which probably gave rife to what is faid in the hiftory of Barlaom, relative to a worhip rendered by the Egyptians 
to thorns *. This pretended devotion extended probably no further than to adding fome branches of acafia, when the firft fruits of the earth were carried in proceffion: nothing of that kind was feen in the interior of the temples, where ftatues, or human figures, were very rare; and little elfe was feen than fome animals, a few vafes filled with the water of the Nile, and lamps never permitted to burn out. By means of the perpetual light in the temple of Jupiter Ammon, feveral attempis were made to afcertain the duration of fome celeftial revolutions; but, as the ancients themfelves perceived, they could never pro. duce any advantage.

Such is the enumeration of the fetiches, among which the Egyptians fought all kinds of fimilitudes with the ftars, the moon, the fun, and the attributes of the Divinity : their objects conftituted, in general, the fymbolical worfhip, fo improperly confounded with idolatry. The Indians, likewife, were confidered in Europe as idolaters, while we had to depend entirely on the affertions of miffionaries and travellers; but their books, when tranlated, proved how much they had been mifreprefented. We do not pretend here to fpeak of the populace of India, for they, like the common people of Egypt, went aftonifhingly aftray; but if ever fanaticifm was its own punifhment, it muft be in the cafe of the Hindoos : they fubmit

- Egyptii coluerunt cattum, et canem, et lupum, et fimiam, et dracom nem, et ajpidem. Alii cepas, et alliaj et Jpinas. Ad calcem Oper, Damas. 
to the moft rigid forts of penance; but the fevereft of all, according to their own confeffion, is the performance of a pilgrimage to the pagoda of the Great Lama, where they can arrive only by traverfing, during thirteen or fourteen months, the moft frightful deferts, at the mercy of the Tartars and beafts of prey; thofe, who are more devout than the reft, continue their journey into Siberia, to vifit the kutuktus, or particular bifhops; and thus fuch wretches are found carrying their provifions on their backs from Calicut to Selinginfkoi, in the fiftieth degree of north latitude. Until more information is acquired, relative to the motives of thefe prodigious journies, it will be difficult to perfuade me that the religion of Hindoftan is not derived from that of the Lamas.

However warm climates in general may tend to affect the human heart with fuperftition, yet that in. fluenee is peculiarly remarkable in Egypt: the priefts do not feem to have had any intereft to increafe the perverfe genius of the fanatics; becaufe they poffeffed a fixed revenue from lands, which were ceded to farm. ers at a very trifling rent, and confequently not fubject to variation. From this were deducted the fums neceffary for repairing the temples, procuring victims, and defraying all the expences of facrifice. They fhould not, therefore, be compared with thofe infamous vagabonds in Italy, who, borrowing their name and character, begged in the ftreets of Rome, from the fecond hour of the day to the eighth, when they returned to thut the temple of Ifis: Such conduct 
duet would not have been permitted in Egypt among the vileft clafs of men, much lefs among the priefts; for no beggars were tolerated by the law.

When the members of the facerdotal order enjoy a certain income, and are prohibited from begging, they muft furely be interefted in maintaining the eftablifhed religion, whatever it may be: But no inducements remain for introducing new fuperftitions, which muft appear to them as more dan. gerous than ufeful.

The partition of lands in Egypt has always been confidered as an effential defect in its political confti. tution. Diodorus pretends, that one third part, amounting to fix hundred and fifty fquare leagues, was in poffeffion of the facerdotal clafs; and as an equal portion belonged to the military, and another to the fovereign, none remained for the people. Yet this ftatement could not have been exact; for the conquerors, called the thepherd kings, forced the people to give up their lands; and we know that they were afterwards reftored on the expulfion of thofe banditti.

No dependance can be placed on the opinions of Herodotus and Diodorus, with regard to the real principles of the government of -Egypt. The conftitution had been certainly changed ever fince the days of Sethon, who fpread fo much confufion round the throne, that no medium could be found between extreme liberty and exceffive flavery. As all mo. narchial fiates have fome degree of fplendor under their firft defpots, before they fink into eternal ob- 
fcurity; in the fame manner did Egypt appear brilliant for an inftant before its fall.

Mr. Schegel, known by his learned Commentary on the work of the Abbé Banier, fuppofes that each Egyptian prieft poffeffed only twelve arouræ, which do not amount to the fame number of acres. Were our modern bifhops and rulers of monks reduced to the fame quota, fo far from riding in their carriages, they would farcely be able to purchafe fhoes. Some authors, like Pierius, have fuppofed that the laws of Egypt did not permit the facerdotal clafs to keep horfes; and the regulation of Mofes might perhaps refer to that particular difpofition : but many of the learned are of opinion, that it related only to the climate of Paleftine, which was peculiarly unfavorable to thofe quadrupeds. At all events, as his intention was evidently to change a race of thepherds into hufbandmen, he acted wifely in prohibiting horfes; and indeed a more effectual plan could not be devifed for reforming the morals of the Bedouin Arabs, whofe high-bred mares are to them what hips are to the Algerines.

It muft be acknowledged, that we are at a lofs to determine the real divifion of lands in Egypt. By making each portion in the facerdotal order amount to twelve arouræ, the fame inconvenience arifes as in the military diftribution, where, according to Herodotus, the quota of the general was not greater than that of the private foldier; and this can never. be credited. The fovereign, or the ftate, had to pay a certain fum in money or grain to thofe priefts who 
were fent to Thebes for the adminiftration of juftice. From this we may infer that the produce of their lands was not very confiderable, particularly for married men; and no others, it appears, were ever admitted to the exercife of public functions. In this, at leaft, a few traces are feen of what fome have affected to call the wifdom of the Egyptians. Their priefts, befides being magiftrates, had the infpection of the laws, archives, hiftorical records, public education, compofition of almanacks, aftronomical obfervations, furveying of lands, meafurement of the Nile, and, finally, every thing belonging to medicine, falubrity of the air, and embalming. Thus, including their wives and children, they amounted perhaps to one feventh part of the nation. Very erroneous ideas, concerning that body of men, are formed by thofe who compare them to the clergy of any country in Europe; where feven or eight convents of monks fometimes poffefs more revenues than the whole facerdotal order of Egypt. Yet the latter performed continual labors; and being fubdivided into different claffes, each had particular occupations. The firft comprehended the prophets, who prefided at the tribunal, where their decifion was given without fpeaking, merely by turning the image of Truth to one or other of the parties. If the reprefentation of a fuperb monument of Thebais, inferted in Mr. Pocock's Travels, can be regarded as exact, the judge held that image fufpended at the end of a kind of fceptre, and not hanging to his neck, as is commonly fuppoled. 
The ancient Greeks had fallen into egregious errors, with regard to the fignification of the word prophet, although it originated in their own language; and Plato took fome pains to adjuft their ideas. Thofe, fays he, are truly ignorant, who imagine that the prophet predicts future events ; for that belongs, continues he, to the mantis alone, and he is always a fool, a madman, or a maniac. From this it refults, as Plato obferves, that the prophet was nothing more than the interpreter of the prediction, and could not be the author; becaufe it was requifite for him to be in his proper fenfes, which was irreconcileable with the fpirit of prophecy. Thus the miferable being, qualified with the name of mantis, like the Pythia of Delphi, was nothing more than the inftrument of fuperftition; for all depended on thofe who interpreted the oracle. If we read, that the Pythia fometimes received money to give favorable anfwers to one town in preference to another, it muft not be believed that the alone was bribed, but all the troop of fycophants attached to the oracle of Delphi.

With regard to the Egyptians, Clemens of Alexandria points out pofitively what were the functions of their prophets. It was neceffary for then to be well verfed in jurifprudence, and to know exactly the whole collection of laws human and divine, inferted in the ten firf canonical books, which were fuppofed to contain every thing relative to religion. Thus the prophets were not remarkable for being learned in profane fcience; while the facred fcribes, or hierogrammatifts, 
grammatifts, from applying themfelves to the fudy of hiftory and natural philofophy, attracted great confideration, and were ranked before the aftronomers and geometricians, or arpedonaptes, who neverthelefs belonged to the firft clafs, as well as the hieroftoliftes*.

After thefe came the comaltes, who prefided at public feafts, the zacores, niocores, and the pafaphores, who took care of the temples, and ornamented the altars, the fingers, Ipragiftes, phyficians, embalmers, and finally, the interpreters. The latter appear to have been the only people capable of fpeaking a little Greek; for the other priefts knew nothing but the Egyptian language, which differed very little from that of Ethiopia. During the conquett of the thepherd kings, it was found impoffible for thofe who fpoke only Arabic, or the Phenician language, to make themfelves underftood by the Egyptians. This - obfervation, as well as many others, tends to prove the error of thofe who imagine Egypt to have been peopled by Arabs, who had paffed the ftrait of Bab. el-Mandel. In that cafe, inftead of being fo very different, the Egyptian language muft have remained a dialect of the Arabic.

With regard to certain monks called Sanjes and Renobotes, faid to have lived in Egypt many centuries

* Aulus Gellius, and Macrobius, attribute, great \&ill in anatomy to the Egyptians. 'Ihey pretend that their priefts of the firft clafs were confecrated by rubbing balm on the ring-finger of the left hand, the vein of which they believed came directly from the heart. 
before the exiftence of Chriftianity, and even prior to the invafion of Cambyles, we may venture to affert, that the whole is a fiction; becaufe no fuch drones arc mentioned by any of the Greek authors, who ever wrote concerning Egypt. Neither can we fuppofe, that a clafs of men could have remained in that country, who, belonging neither to the clergy, the military, nor the people, muft have been more expenfive than all the other facred animals together. It was in the time of confufion occafioned by the defpotifm of the Roman emperors, that Egypt firft became a prey to legions of cenobites; and that plague alone proved more fatal than all thofe re. corded in the annals of the Jews *.

Although Mr. Schmidt has publifhed a very learned Differtation on the priefts of Egypt, it mult be remarked, that an effential particularity, forming one of their exterior characteriftics, has efcaped his attention. They carried, in the fame manner as the kings, a fceptre exactly in the form of a plough $\dagger$. This cuftom feems to have been taken from the ancient gymnofophifts of Ethiopia, who afferted, that the firft alimentary grain was found near the cataracts of the Nile; and it is faid that a fpecies of

* The firt Chrittian monks of Egypt were called, in the lan guage of the country, Sarabait, which fignifies people difobedient to the magitrates, according to the interpretation of Bochart. The word Remobotes is perhaps a corruption of Remoites, which feems likewife to denote factious people.

+ Sacerdotes Exyptiorum at IEthiopum gerunt Sceptrum in formam aratri faclum, quo reges etiam utuntur. Diod. Sicul, lib. iv. 
wild fpelt really grows in that neighbourhood. The learned have had opportunities of feeing frequently the aratriformed fceptre of the kings and priefts of Egypt on different monuments, and even in the hands of the mummies, without knowing it to be fuch. Mr. Cleyton makes it an inftrument altogether ridiculous *, and Father Kircher, the moft unfortunate of men in his conjectures on hieroglyphics, fuppofes it to be an alpha. Indeed the Theban plough has fome little refemblance to the letter $\mathrm{A}$; but he fhould have perceived that this was not the firft of the Egyptian characters; for we know that they began by the $t b o t h$, in honor of the genius who prefided over fciences. Thefe fceptres, in the form of a plough, are much lefs difgufting than the long nails of the Chinefe; and it might appear extraordinary that the Egyptians thould have taken from an inftrument of that kind the chief emblem of royalty and priefthood, were we not affured of the great refpect they always preferved for agriculture. Even their gods are reprefented cultivating the earth, and toiling in the fields, according to that allegorical ftyle which has been the fource of fo many fables; and thus Ofiris was faid to have conftructed his own plough, and opened the firt furrow $t$.

Egypt contained four choniathim, or celebrated colleges : that of Thebes, where Pytheras ftudied;

* Journal from Grand Cairo, written by the Prefetto of Egypt.

$\dagger$ Primus aratra manu folerti fecit Ofiris,

Et teneram ferro folicitavit bumum. Tibullus, lib. i. 
that of Memphis, where Orpheus, Thales, and Demo. critus are faid to have been inftructed; that of Heliopo. lis, frequented by Plato and Eudoxus; and finally that of Sais. The leginlator Solon vifited the laft, moft probably with the hope of difcovering fome memoirs relative to the town of Athens, which paffed among the Greeks for a colony founded by the Saites. As this college was lefs ancient than the reft, it had not the right of fending deputies to the great council of the nation at Thebes, where ten members from each of the other three, formed the tribunal of thirty, prefided by a prophet, to whom hiftorians have given the title of Archidicaftes.

It is difficult to fay in what manner the Greeks, who fojourned in Egypt, paffed their time. Plato feems to have tranfacted commercial affairs; and they, in my opinion, interefted him more than the ftudy of the fciences, or the hiftory of the Egyptians, concerning which he has given us fcarcely any inform. ation, although he refided thirteen years at Heliopolis and Memphis. Yet the continental voyages. of the Greek philofophers and poets have contributed more than any thing elfe to illuftrate the hiftory of that region. Without their aid, and the annals of the Jews, we could have known little of a coun. try, where all the monuments are dumb, and not 2 fingle volume remains of the whole library of Thebes.

What Eufebius relates of a college at Alexandria, compofed of priefts who were all hermaphrodites, must 
mult be confideréd as entirely fabulous*. On the contrary, no perfon, who was born with any remarkable bodily imperfection, could be confecrated in Egypt; and the very animals, when deformed, were never ufed either for facrifice, or in fymbolical worhip. Eufebius, pretending to praife Conftantine, places bcldly among his greateft actions the order given by him for nlaughtering without mercy all thofe pretended hermaphrodites of Alexandria. Could this account be credited, it muft increafe our deteftation of a monfter who thould have been long before tired with affafination. Nothing could be more abfurd and cruel than to inflict death on women, who were unfortunately condemned by nature to a deformity not uncommon in Egypt ; and, fortunately, we find no other ecclefiaftical writer bearing teftimony to this pretended murder. Conftantine, however, acted with very little policy, in removing the portative Nilometer from the place where it was generally kept; and this inflamed ftill more the minds of the people, becaufe they perceived that he acted in trifling matters from inftigation. Whether that inftrument remained in the temple of Serapis, or in a Chritian chapel, did not affect in the leaft the overflowing of the Nile; but his conduct violated extremely thofe ancient ufages, which fome nations confider as their chief riches.

- In Vit. Conftant. lib. iv. c. 25.-The Greeks of Alexandria profeffed a worhip very different from the ancient religion of Egypt.

Conring 
Conring has been more zealous than any other modern writer in combating the phantom of Egyptian wifdom. After reducing all the pretended philofophy of that country to a collection of grofs opinions, he accufes the very phyficians of holding a conftant intercourfe with demons, and of being utterly incapable of curing any diforder*. From this we may judge that Conring was not the greateft philofopher of his age; and by writing fuch palpable abfurdities, he difgraced his own judgment more than the reputation of the Egyptians, who had befides to fuffer the unjuft imputation of atheifn. This muft be the cafe, it was faid, becaufe they give two fexes to each element, and conclude by their great maxim, that God is all. But in fact they never pretended that the elements could produce by their own inherent power alone. On reading attentively what the naturalift Seneca fays on this diftinction, we perceive that it was merely a vulgar method of expreffing the difference between fire and light; between vegetable and mineral fubftances; between air in a calm and in an agitated ftate; between frefh and falt water + . However ridiculous this may appear at the prefent day, it was far from being fuch in thore

* De Hermetica Medicina, cap. x. \& xi.

+ IEgyptii quatuor elementa fecere: deinde ex fingulis bina, marem et faminum. Aerem marem judicant, qua venetus ff: faminam, qua nebulofius. $\mathcal{E}$ iners. Aquant virilem vocant mare; muliebrem,omnem aliam. Ignem vocant mafculum, qua ardet flamma, E faminam qua lucet innoxius 1adu. Terram fortiorem, marem vocant, faxa cautefque; farmine nomen afignant buic tradabili ad culturam. Seneca, Nat. Quxft. lib. iii. cap. 14. 
diftant times, when natural philofophy, like a child beginning to walk, made its firft efforts to leave the cradle. The Egyptians thought to have done a great deal by perceiving that nature poffeffes four elementary fubftances. Their ideas on this point were infinitely more rational than thofe of the Chinefe, who extend the number of elements to five, although they exclude the air; and as their imagination is heated, they pretend that their bing, or elements, are animated by five genii, who produce fucceffively a dynafty of Chinefe emperors. Thence, fays Vifdelou, proceeds that formula fo common in their books: Such a dynafy reigned by the virtue of wood; fuch another by that of metal, earth, fire, or water. The yellow color would make us fuppofe that the Tartars are now confidered as belonging to the earth; but Vifdelou affures us, that their dynafty is believed to be produced by the genius of water. From this we may conclude, that the Chinefe are the greateft metaphyficians in the world.

The axiom, God is all, has in itfelf no precife meaning; but, depending on interpretation, may be explained in very oppofite fenfes. It feems therefore to be very improperly introduced as proving the atheifm of the Egyptians. Yet all the efforts of Cudworth to juftify them, although the cafe was not difficult, failed entirely, becaufe he confided too much in thofe apocryphal works, known by the title of Hermetic Books, which are the confufed and defpicable forgeries of fome Chrifians. Afterwards he applies to the authority of Jamblichus, who, 
if he even had not been a fool or a vifionary, could never be fuppofed to poffefs any knowledge of the Egyptian doctrine relative to the effence of the Divinity, when he mentions Ofris as one of the three chief gods, as Cudworth himfelf acknowledges*. "This blunder enervated the force of all his other proofs; for Ofiris, fo far from being in the firft rank of the gods, did not belong even to the fecond.

As Warburton believed that the unity of God was announced in the celebration of the myfteries originally inftituted among the Egyptians, it refulted of courfe, that they could not be atheifts. Thefe myfteries became afterwards a branch of finance for the republic of Athens, where the admiffion was fo very expenfive, that Apulæus rallies Lucius with having frequented fuch ceremonies, until he had reduced himfelf to his only robe; and the priefts advifed him to part with that likewife, to be initiated anew $t$. This demonftrates that the work of Apulæus, fuppofed by Warburton to be an excellent apo-

* Cudworth, Syft. Intellec. cap. v. Jambilchus de Myit. Egyptiorum, fect. viii.

+ Pofremo jufus, vefie iffa mea, quamvis parzula difrata, fufficientem corrafif Jummulam, et idipfum praceptum fuerat Jpecialiter. Met. lib. xi.-This alludes to the myfteries of Ofiris, celebrated at Rome. It is aftonifhing that Warburton thould have made fo little difficulty of believing that on thofe occafions even women and children were told that Jupiter Capitolinus was nothing more than a deified man, unworthy of their incenfe and victims. It is certain that the Jupiter Optimus Maximus was not by any means a deified man. 
logy for the myfteries, was, on the contrary, a fevere fatire on thofe vagabonds, who paffed themfelves for Egyptians in Greece and Italy, where they were called ironically the terreftrial ftars of the great religion. Thofe villains employed every kind of intrigue and profanation to obtain money from the de. vout, and they frequently fucceeded in depriving them of their very clothes. Such was their extreme artifice, that they infpired the hearts of the common people with fanaticifm, at the fame time that they favored all their debaucheries.

It is no longer doubted that the Greek hierophants introduced by degrees great changes into the doctrine of the myfteries of Eleufinian Ceres. If it be true that, in the time of Cicero, they announced fecretly all the gods of Paganifm as deified men, they were grearly miftaken. But even fuppofing that this error was really inculcated among the Greeks, it did not in any way concern the true Egyptians, who never went to Athens to confult the hierophants concerning any point of their religion, the doctrine of which we thall now endeavour to explain. The attributes of the Divinity feem indeed to have been perfonified with them, but in a very different fenfe from that of the Indians, who attach themfelves folely to the power of creating, preferving, and deftroying, reprefented in the allegorical ftyle by three diftinct perfons.

The Egyptians acknowledged an intelligent Being feparate from matter, whom they called Phtha: this was the founder of the univerfe; the living God, whofe wifdom perfonified had the name Neitb, and 
the appearance of a woman iffuing from the body of a lion. Thus the Grecian mythology defcribed Minerva as the offspring of the brain of Jupiter; and little doubt now remains concerning the allegorical identity of Neits and Minerva. It is not neceffary nere to be very prolix in proving that the fphinx, the real fymbol of the Divinity, never could have any reference to the overflowing of the Nile under the zodiacal figns of the lion and the virgin. Independently of many other reafons, it is evident that, in very remote times, the increafe of the Nile did not take place under thofe two figns, even admitting them to be known to the Egyptians, which is far from being demonftrated. The zodiac, fuch as it now appears, is retouched and reformed by the Greeks, although fufficient traces of its origin re. main, to prove that it was invented by the Egyptians. They marked that circle with twelve fections, and each of thefe being again divided into three, the whole fubdivifion amounted to fix-and-thirty. The zodiac of the Chinefe, called the yellow band, has always confifted of twenty-four equal fections; and as each of thefe is likewife fubdivided into three, a totality is produced of two-and-feventy.

The doctrine of the Egyptians with regard toNeith, or divine wifdom, may be fuppofed nearly the fame with that contained in the Hebrew parables attributed to Solomon, who had married a woman of Egypt, where many perfons of the female fex had names derived from Neith, in the fame manner that Sophia was introduced afterwards.

Divine 
Divine goodnefs was the laft attribute of the Supreme Being, perfonified among the Egyptians by the name of Cnupb*, a word famous in the Abraxes. Thus we find this doctrine very different from that of the Indians, with whom the Egyptians had only fome exterior refemblance, which vanifhes in a great meafure, when fubmitted to particular examination. But they differ in every thing from the Chinefe, who have peopled nature with genii, without eftablining among them a proper degree of fubordination. What has been mentioned here is fufficient to prove the illufion of Mr. Jablonfki, when he pretended that the whole Egyptian theology was founded on the fame hypothefis advanced by Spinofa, who, he fancies, muft have read the Hieroglyphics of Orus Apollo. But furely nothing could be found there favorable to his principles; for that Egyptian, born at Phlœnebyth in the Panopolitan prefectory, never fpeaks of the Divinity but as a Being diftinct from matter. Yet, unwilling to truft to my own judgment, where the accufation was fo weighty, and the fubject very obfcure, I confulted on this point, as well as on many others, my ancient and much-efteemed friend Mr. Heiming, canon of Cleves. That man, whofe whole life has been dedicated to ftudy, and who to great genius joins an amazing knowledge in

* Jamblichus has corrupted this word greatly, and Plutarch

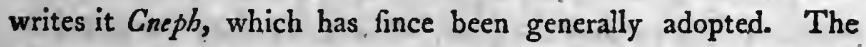
Atbor of the Ægyptians fignified chaos in one fenfe, and in another the incomprehenfibility of God, and his ftate prior to creation.

VOL: II. 
all parts of the fciences, was of opinion that nothing tends to prove that the ancient Egyptians were eren inclined to atheifm. We do not fpeak here of the common people, who in no country of the world ever adopted fuch fyftems; becaufe they are connect. ed with a kind of metaphyfics exceedingly complicated, and deftructive of all found philofophy. Yet we do not pretend to infinuate, that the Egyptians did not fall into monfrous fuperftitions and errors; for even their very princes were filly enough to believe, fometimes, that they really beheld the gods*. Apparitions of that kind may proceed from a natural phenomenon, not unfrequent in any country, except perhaps under the frozen zone, and confifting in a falfe dream fome inftants before the real fleep begins. Perfons in good health, whofe minds are tranquil, and particularly children of both fexes, believe then to perceive heads generally without bodies, which move lightly from one place to another. Perhaps no naturalift or phyfician has ever examined why thofe images, preceding lleep for a few moments, always reprefent heads either of human beings, or fometimes of large animals. This may, perhaps, be occafioned by the relaxation of the vital fpirits, when they begin to calm in the folds and meanders of the brain. The more ardent fanatics of Egypt might have taken

* Hiftory mentions two Egyptian kings, Orus and Suphis, who affected to contemplate the gods. The laft of thefe is fuppofed erroneoufly to have been the author of a book called the Hcly. Amber: that production related to judiciary aftrology, which was much in rague among the Egyptians. 
this falfe dream for the apparition of fome genius, efpecially as it preferved confantly the fame form. Ar this day, the Turkin monks, and certain Arabs of that country, have invented a method of procuring vifions. They begin by very long faftings, and afterwards pray aloud in fome cavern or obfcure place, until their ftrength is entirely exhaufted. Thus a fyncope is produced, during which they imagine that fire iffues from their eyes, and many phan. toms, either agreeable or difagreeable, dance before them. We can no longer doubt but this method was practifed by the Chriftian monks of Ireland on thofe whom they conducted into a cave called the Purgatory of Saint Patrick; and Mr. Sinner was wrong in fuppofing, that it had any refemblance to the myfteries of Eleufinian Ceres*. Hunger principally caufes the delirium of thofe unfortunate wretches, fome of whom never recover; and yet we cannot lament their fate.

The diverfity of the facred animals of Egypt has made fome ignorant authors of the prefent day fuppofe, that the fundamental principles of religion were not the fame in the different provinces. But it is eafy to perceive, that the fymbolical worhip was only fecondary; and that all the animals were confecrated to the fame divinities, afterwards introduced among the Greeks and Romans. Yet no perfon could think of afferting, that religion varied in dif-

* Effay on the Dogma of the Metempfychofis, and of Pur. gatory. 
ferent quarters of Rome, or of Athens, becaufe he faw there the temples of Vulcan, of Jupiter, Minerva, and Apollo, to whom the wolf was particularly confecrated by the Egyptians*. That animal, however, was not more adored in the Lycopolitan prefectory, than the fcreech-owl at Athens, the eagle at Rome, the weafel at Thebes, or the moufe in 'Troas.

It might more juftly have been afferted, that the four great colleges of Egypt did not always agree on feveral points of hiftory, natural philofophy, and aftronomy: that indeed appears well afcertained, and from it proceeded thofe contradictions fo manifeft in all the fyftems attributed to them by the moderns. Pythagoras, who ftudied at Thebes, feems to have imbibed two opinions compofing a part of his fecret doctrine. He maintained, in the firft place, that the earth was a ftar, or planet; and, fecondly, that it moved round the fun: both which opinions were afterwards taught by his difciple Philolaus. Another hypothefis, differing little from that of Tycho-Brahé, had its partifans likewife in Egypt. According to it, the earth was immoveable; but Venus and Mercury were faid to turn round the fun; as we learn from the commentaries of Macrobius on the Dream of Scipio. Although thofe two fyftems feem fomewhat contradictory, it is poffible that they were admitted by different colleges at the fame time. Thus all the difficulty is diffipated, and matters are reduced to this, that as every perfon had the

* Macrob. lib. i. cap. 7 . 
right of thinking as he pleafed at Thebes, the fame liberty was claimed at Heliopolis, Sais, and Memphis. If it be afked again, why Ptolemy rejected the movement of Venus and Mercury round the fun, in oppofition to the authority of the priefts of Egypt; we hall only beg to know, why Tycho-Brahé did not adopt the fyftem of Copernicus. The ideas of man are frequently inexplicable: he fees the light, and directs his fteps towards darknefs.

Seneca fuppofes, without the flighteft proof, that Eudoxus and Conon, during their ftay in Egypt, had made inquiries into the fentiments of the colleges relative to the nature and theory of comets, without being able to difcover any thing. In the firft place, it is very poffible that Eudoxus and Conon never once thought of fuch matters; but fuppofing them even zealous in their refearches, they would probably have found opinions very much divided. Yet the principal points of cofmography were univerfally admitted, and the Egyptians did not difpute on the caufe of eclipfes, which they attributed to a fhade, nor on the form of the earth, believed by them to be round*. If ever any communication had been open between that country and China, the pretended learned in the latter would not have been found, at the arrival of the Jefuits, making the earth fquare, and difcovering fo great ignorance of the caufe of eclipfes. They imagined in the firmament, fays. Father Kircher, fome genius who placed at times

* Diogen. Laër. in Proem. 
his right hand on the fun, and his left on the moon * Then the drums and kettles were heard beating on every fide; the moft timorous concealed themfelves in cellars; and the emperors frequently trembled on their throne.

It is eafy to believe that, in Egypt, philofophical opinions never troubled public tranquillity, nor agitated the ftate; and we have fhewn likewife, that the diverfity of animals, confecrated to the gods, never occafioned any difputes between the different provinces, as long as that country remained under its own civil inftitutions. But when conquerors introduced new laws, and a police altogether defective, then indeed both hatred and jealoufy began to appear, and the factions of the towns were dreadful. Warburton affures us, that hiftory affords only one inftance of that kind; but by a little examination he would have found at leaft four examples, without including the riot occafioned by that Roman, who had killed a cat, and committed moit probably fome other exceffes againit the eftablifhed cuftoms of the country. This was highly refented by the Egyptians, who always willingly rifked their lives to obtain vengeance, and were remarkable for a fingular obftinacy in fupporting torture wirh patience $f$. The greateft torments frequently proved ineffectual in making them reveal a fecret, or pay the tribute required by

* China Illuftrata.

$\uparrow$ Esyptios aiunt patientifime ferre tormenta: Es citius mori lominem Asyptium in quaflionibus toritum, animatumque veritatem protere. AElian, Hit. Diverf. lib. vi.' Ammianus Marcellinus, lib. xxii. 
the Romans, to whom they did not confider themfelves at all indebted. Yet that obftinacy was extremely different from true courage, and ftill more, if poflible, from what is called heroifm.

Warburton maintains likewife, that the combat of the Tentyrites and the pretended Ombites was not the effect of religious difputes. It did not indeed refemble the religious wars in France and England, becaufe only one man was flain : but yet we difcover the fame fanaticifm, excited through interefted views, not difficult to be detected, however apparently involved in darknefs.

The difputes between the Cynopolitans and Oxy. rinchites concerning their dogs and pikes, termimated in open war. The Romans, who had then many regular troops in Egypt, might eafily have prevented thofe unfortunate people from proceeding to extremities. But they were allowed to fight, and when weakened by mutual lofes, they received fuch cruel chaftifements, that nothing feemed to them more defirable than peace. When we fuppofe that interefted motives were probably concealed then under an exterior of religious zeal, it fhould be ob. ferved, that this opinion is fupported by the teftimony of Mr. Pocock, and other modern travellers, concerning the frequent combats of the Arabs, who now inhabit both banks of the Nile. Such riots among thofe Mahometans were never occafioned by the facred animals, any more than the quarrels of the ancient Egyptians. Even in Europe, we find frequent enmities fubfifting between towns fituated near each other on oppofite banks of the fame river: 
they cannot poffibly be alike flourining, and this inequality of fortune and power irritates the minds of the people. It was owing to the evidently corrupt text of Juvenal, that the falfe opinion prevailed of the Ombites having fought with the Tentyrites about their crocodiles. Tentyrus and Ombos were about one hundred miles diftant, and therefore not likely to have great interefts to promote under fuch vain pretexts. The difpute alluded to really took place between the Tentyrites and the inhabitants of Coptos. That town became exceedingly flourifhing, when a way was opened from the centre of Thebais to Berenice; for all the productions of India, Arabia, and the coaft of Africa, were brought thither on camels, and partly forwarded thence in boats to Alexandria. In this paffage they had to pafs under the walls of the Tentyrites, who had no thare whatever in that commerce, although their fituation muft otherwife have been very profperous, as we judge from the ruins ftill extant of their magnificent temples. Prior to the reign of the Ptolemies, when the Egyptians had no road in Thebais, nor any veffel on the Arabian Gulph, it was not poffible to forefee, that Coptos, fo far from the Nile, would one day poffers the richeft commerce in the univerfe. The unex: pected good fortune of that town excited the jealoufy of the iahabitants of Tentyrus; and we cannot be furprifed that it produced civil war under the Romans*.

- Juvenal fays pofitively that this difpute took place between the ithabitants of Tentyrus and Coptos:

Gefla juser calida referemus mania Copti. 
Although the capital towns of the Cynopolitans and Oxyrinchites were upwards of twenty miles diftant, yet their prefectories either adjoined, or had no other feparation than the Nile. Cynopolis feems to have poffeffed little cultivated country; while Oxyrinchus was exceedingly flourifhing, and its good fortune withftood all the dreadful revolutions of Egypt fince the days of Cambyfes, until the Chriftian monks at length occafioned its total ruin. It was faid to have contained at one time no lefs than thirty thoufand of both fexes; but this muft be confidered as a grofs exaggeration. The Abbé Fleuri fhould have exercifed more criticifm on what he copied from ecclefiaftical writers, and particularly from Ruffin, concerning this dreadful fcourge, which has defolated Egypt ever fince the third century. By fuppofing that only one fourth of thirty thoufand cenobites inhabited Oxyrinchus, then the metropolis of Heptanomis, the number would have been fufficient to depopulate the town, and reduce it to a wretched burgh, now fuppofed to be called Babnefé.

The firt monks of Egypt, who replaced the Therapeutes, and copied many of their obfervances, inhabited the deferts, and labored for their fuftenance. In that fituation they fhould have been allowed to remain, inftead of being introduced into towns, where their morals became corrupt, and their begging importunities intolerable. No other means, it would feem, could then be found of efcaping fuch yexations than by turning monk likewife; and thus the monfter, by confuming its own vitals in proportion 
tion as its fize increafed, could not avoid deftruction. Monaftic orders are never nearer ruin than when they become numerous; becaufe, like edifices without any foundation, although they may efcape a few thocks, they muft certainly be overturned at laft.

The Englin acted wifely by not allowing more than one convent to remain in their whole country: but the Turks, who govern Egypt blindly, feem to rely on the Arabs entirely for extirpating the mo. nafteries. It it certain, as Mr. Niebuhr infinuates, in his Defcription of Arabia, that a remarkable antipathy fubfifts between the Bedouins and the monks, who are generally very ill treated, when they fall into the hands of thofe enemies. They fufter frequently fuch fieges in their houfes, that they become infected with the leprofy or fcurvy, like failors in long voyages from a fcarcity of vegetables. At this day, about forty convents ftill remain without the walls of the towns in Egypt; and their number feems to decreafe in the fame proportion with the bifhoprics. The latter, according to an ancient Greek catalogue, once amounted to eighty-two *; but they are now reduced to eleven, exclufive of the Abouna of Abyffinia, and another prelate who refides at Jerufalem, where his fate is not preferable to that of the other bifhops who remain in Egypt. They are in general obfcure men, and fo very poor, that they

* This catalogue is indeed held very doubtful, becaufe it calls Scene Mandroram a bifhopric. But that place, as well a's others Atill more inconfiderable, really held that rank; and the greater part of the bifhops of Egypt were only vicars.

fcarcely 
fcarcely live; becaufe the Copts, who do not exceed twenty-five or thirty thoufand families, are incapable of maintaining and clothing them decently. Thefe facts are fufficient to give fome idea of the manner in which that unfortunate country is governed by the Turks.

It has been already obferved, that the revolt of the Egyptians, who attempted to deftroy the labyrinth, was likewife a religious rage of the moft reprehenfible kind. But that fanaticifm broke out under the Romans at fome period between the reign of Auguftus and that of Vefpafian, or Titus. Strabo fpeaks of the labyrinth, as having never received any injury; and Pliny mentions how much it fuffered from thofe who inhabited the town of Hercules and its environs. By this we find, that the event took place later than the voyage of Strabo; and nothing but the inclination of the Romans was wanting to have prevented that diforder.

Some authors, too much prejudiced in favor of ancient Egypt, have vainly endeavoured to juftify every thing, however vicious or abfurd, appertain. ing to the workhip of that country, which was the mother of the arts, and the fchool of fuperftition. According to them, religion in time changes fo entirely, that even the hadow of its primitive form can no longer be difcovered: but we find, on the contrary, that the great maxim of the Egyptian. priefts was to prevent all innovations in religious matters, and their difciple Plato imbibed that opinion fo ftrongly, that he conceives no greater madnefs 
than to change any thing whatever in public worthip*. All ceremonies and facrifices, fays he, whether adopted from the favages, or introduced by thofe who confulted the oracles of Delphi, Dodona, or Ammon, fhould be allowed to remain precifely as they are. Similar ideas are difcovered in the preliminary difcourfe of Zaleucus and Charondas, as well as in the works of Cicero; and we are therefore led to affirm, that the mont celebrated legiflators of antiquity preferved invariably the fame fentiments both in theory and practice. Solon, who reformed the whole republic of Athens, and pointed out even the proper places for bee-hives and water-pits, never mentions a fingle word concerning the religion of the Athenians $t$. We cannot confider, under that point of view, his laws and inftitutions to diminifh luxury in burials; and this evil, fo general in the whole world, fhould have been repreffed at Rome by the vigor of the twelve tables: nothing, it is faid, muft more certainly deftroy the power of the Tartars in China than their funeral expences, if fome means are not adopted for reftraining this fpecies of oftentation, fo common to all the ancient Scythians.'

Thefe details may ferve to anfwer the inquiries of thofe who are aftonifhed at finding fome nations, in former times, uniting the wifert laws with the moft

* De Legibus, Dial. $\nabla$.

† Solon is faid to have built a temple at Athens to the vulgar

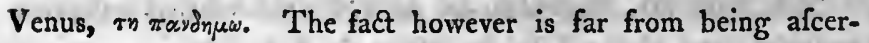
tained, and we cannot thence conclude that he introduced any reform into religion. 
foolith religion. The greater part of their religious worlhip had been continued from favage life; and civil inftitutions, on the contrary, could be framed only in a ftate of civilization. When the maxim was eftablifhed of admitting no innovations in fuch matters, many nations, otherwife very polifhed, continued to oblerve ceremonies invented by barbarians. The legiflators we have mentioned fell into this error, becaufe they made no diftinction between the effence and mere acceffory parts of religion: befides, as the laws rendered them odious to all the vicious, it would not have been prudent to increafe the danger, by incurring likewife the hatred of the fuperftitious.

Pharaoh Bocchoris conceived the idea of removing the facred bull, called Mnevis, from the town of Heliopolis, and by that means he loft entirely the efteem of the people, among whom fuch animals had been worhipped for a greater length of time than the Roman empire exifted. Apis did not difappear altogether at Memphis, until the reign of Theodofius; and, according to Mr. Jablonki, the firft had been confecrated one thoufand one hundred and feventyone years before our prefent era. Thus a regular fucceffion had taken place during a period of at leaft fifteen hundred and fifty years : but we are induced to fuppofe it much longer, becaufe Mr. Jablonfki has been guided by the fentiment of Eufebius, and in fuch matters that of Manethon feems preferable*.

The dietetic regimen of Egypt was wholly relative to climate, and as moft of the feafts and ceremonies

*. Pantheon Egyptiac. lib, iv. cap. 2. 
were connected with agriculture, the overflowing of the Nile, or aftronomy, the priefts concluded that their worfhip, like nature itfelf, thould be invariable. Befides, they faw the fields well cultivated, while good order and abundance reigned in the towns, and they concluded that a country could never have become fo flourifhing with bad religious inftitutions. But without citing any of the examples before our eyes, it is certain that antiquity prefents a great num. ber of very profperous ftates, where the religion was nothing more than a tiffue of abfurdities and palpable chimeras. In fuch cafes all the advantages enjoyed by the fociety fhould be attributed to the nature of the police and civil laws. It is not however the defective regimen of Egypt which frould be blamed; neither do the fealts relative to agriculture deferve the animadverfions of philofophers. Thofe ufages, refpectable in every point, are worthy of the highent praife. But the fcandalous diforders committed in the Mendetic Nome; the worfhip of ani. mals in general; the licentioufnefs introduced in the proceffions and pilgrimages; the cruel difcipline of the derotees, and the indecencies permitted at the inftallation of Apis, excite abhorrence. When we add to thefe, and a thoufand other fuperftitions, the exceffive expences occafioned by the embalming of certain animals, it is impoffible not to reprobate the oracle, which declared the Egyptians to be the wifeft of nations, as Socrates was ftyled the wifent of mankind. The power of truth may have operated in favor of a philofopher; but this extravagant praife 
of the Egyptians could only proceed from a fentiment of gratitude in the Greeks. They did not forget their being indebted to them for the arts and fciences; and fcholars are inclined to believe them. felves inferior in knowledge to their mafters, even vihen they might well difpute the palm.

All the abufes we have mentioned prove, that the maxim of permitting no innovation in religious matters was falfe and pernicious; whatever may be advanced in its favor by Plato. The Egyptians at all events might have been allowed to preferve what was called the weeping worhip, becaufe gloomy people may require at times to be abandoned to their melancholy: but it was folly to let fuch men fcourge themfelves in the temples. Thofe who get fo far bew yond nature, inftinct, and reafon, are capable of any crime, and can never be reftrained by civil inftitum tions. Thus it is found in Italy, that the proceffions of flagellants are generally compofed of the greateft villains.

The doctrine of the Egyptians concerning the future ftate of the foul appears to have been very complicated. -Mr. Mofheim has even fuppofed that two opinions entirely oppofite reigned there *; becaufe he could not reconcile the fentiments of ancient writers, fome of whom affirmed that the people adhered to the metempfychofis, while others denied the fact. But this contradiction, which certainly exifts among

* Ad Syftem. Intelleet. Cudworth, cap. iv. - Servivs, the Commentator of Virgil, attributes likewife a fingular opinion to the Egyptians, which however is evidently falfe. 
authors, did not exift among the Egyptians, who do not appear to have ever known in early ages the doctrine of the tranfmigration of fouls. What we find ad. vanced in the works of Clemens of Alexandria, Diogenes Laertius, Philoftratus, and the Poemander of the pretended Hermes, originated entirely from Herodotus, who in that point has been greatly deceived. This cannot furprife us when we perceive the manifert errors adopted by the Romans and Greeks in writing on the religion of the Jews, to whom they afcribed different opinions totally unknown to that nation; and they could not have been actuated by any intention of rendering them odious, 'becaufe that required no calumny. But their mifreprefentations proceeded folely from the little pains taken by thofe writers to obtain information; and the Romans in particular were fo ignorant in fuch matters, that they neither knew the hiftory nor dogmas of Judaifm, even when it was tolerated at Rome. Are we to be perfuaded after this, that a man like Herodotus could not be deceived in writing the religious tenets of the Egyptians; efpecially as he knew nothing of their language, and had to confult interpreters, who, on the fingle article of the pyramids, amufed him with fuch lies as can no longer be believed, even by children?

Thofe who adopt ftrictly the fyftem of the tranf: - migration of fouls, like the Thibetans and Hindoos, take little pains about their dead bodies: they either commit them to the flames or to the earth immediately; while the Ethiopians and Egyptians 
did every thing poffible for their prefervation. On this account they held the fea in horror; for thofe who were drowned had but little chance of being embalmed. Yet as they continued to navigate the Nile, particular priefts were appointed to drag for the carcaffes, and convert them into mummies at the public expence. This averfion to the fea was no inconvenience as long as the Egyptians neither had nor winhed to have any fleet; but when other times brought different fentiments, it became neceffary to mitigate that opinion, which was alfo adopted inconfiderately by the Greeks and Romans. Prophyry has preferved a prayer recited for the dead in Egypt*; and it proves to our fatisfaction that the people of that country neither adhered in the leaft to the fyftem of the metempfychofis; nor to that of fatality, which-excludes all future rewards and punifhments; nor to that called moral or real, where both are admitted. Plutarch gives us to underftand clearly that thofe people were miftaken who believed that human fouls paffed into the bodies of facred animals; and that opinion was attributed with as little foundation to the Egyptians, as the adoration of fwine and affes to the Jews. Had the Egyptians thought like the Bramins on all thofe matters, they would not have fed on the fleth of animals, nor immolated bulls, calves, goats, theep, and many other victims which the Bramins dare not eat, and

* De Abftinentia ab Animal.

VOL. II.

L

much 
much lefs flaughter*. Any act of that nature, be* fides future punifhments, would entail on them the ignominy referved for the pouliclis and the patial, concerning whom we have reafon to with for more information. Occafion has already been taken to obferve how many fables are introduced into the narratives of certain travellers; and lefs acrimony fhould be teftified towards thofe who examine their affertions by the aid of found criticifm. Every precaution is certainly neceflary at this day to prevent Europe from being filled with fuch falfehoods as thofe concerning the giants of Magellan. It is however without reafon that the poulicbis and patiab are faid to reprefent in India two Egyptian tribes, called by Herodotus the caftes of boatmen and fwine-herds.

The Indians differ exceedingly from the Egyptians by rejecting circumcifion; by admitting a hell in the loweft part of the Onderab; and finally, by believing that endlefs chaftifements are referved for certain crimes, fuch as fuicide and beftiality $t$. The Egyptians

* Holwell defcribes the chaftifement referved for the Bramins who kill animals, chap. iv.

+ Suicide, according to the Indian tenets, is an inexpiable crime, becaufe it interrupts the courfe of tranfmigration. How they can reconcile the conduct of the women who commit themfelves voluntarily to the flames. with their religion, is difficult to conceive; for their death is as much fuicide as that of Calanus and fome other Bramins mentioned by the ancients.

It has been impoffible for me to learn what was the doctrine of the Egyptians concerning fuicide, or how far it was conformable 
thans reprobated the idea of eternal punifhments, and believed only in purgatory, called in their language Amenthes. From that place no road led directly to heaven, and thofe who entered there had to refume at a future day their former body, or the matter they had firft animated. According to the theology of the Egyptians, the philofophers, and thofe who had practifed the moft rigid virtue, were the only people whofe fouls went directly to dwell with God, without pafling through purgatory, or ever being fubject to refurrection. It is proper to obferve, that in this point alone their dogmas have fome little affinity with thofe of the Hindoos.

In the Egyptian ceremonies a public confeffion was made in the name of fome dead perfons, declaring that they had conftantly honored their parents; that they adhered invariably to the religion of the ftate; that their hearts were never fullied with a crime, nor their hands tinged with human blood in the midit of peace; that they had preferved and religioufly difcharged every truft confided to them; and finally, that during their whole lives they had never given reafon to any perfon to complain of an injury. All thefe conditions were evidently indifpenfable for thofe who hoped to efcape the amenthes or purgatory;

to that of the Greeks. The latter were probably the inventors of the whimfical ceremony of of cillation, intended ta aid the fouls of thofe who had hanged themfelves to pafs the Styx. For this purpofe fmall figures were fufpended by cords, and kept a long time in motion, to ferve inftead of funeral ceremonies, which the religion and the laws refufed to thofe who took away their own lives. O curas hominum! 
and to me it appears obvious that this doctrine on the duties of the man and of the citizen is an extract from what was read in the leffer myfteries, where it was probably difplayed on two tables of ftone. The Greeks affure us pofitively that two fuch tablets were brought before the initiated; and that circumftance tends to explain numberlefs difficulties.

We are here hiftorians: our object is only to enumerate the different opinions, without attempting to indicate precifely how far they were either whimfical or ufelefs, like that of making fouls return from amentbes to re-inhabit the earth. The uncertainty relative to thofe who were to refume their former Atate, or pafs immediately into heaven, rendered it neceffary to embalm every perfon through precaution; and Plutarch fays, that two places in Egypt, near Memphis and Abydos, were preferred to all others for interment. We have already remarked, that mummies, although very common at Memphis, are exceedingly rare towards Mad-fune, or the buried town; either becaufe a mountain of ruins fruftrates all attempts to penetrate into the vaults, or elfe the bodies depofited there are lefs numerous than has been generally believed. $E l-B e r b i$ is properly the place where the famous temple of Abydos once exifted: but now even the pedeftals of the columns are removed, and cut into millftones, by the Turks and Arabs, whofe paftion for antiquities extends no further. Mr. Niebuhr, who was fent into Arabia by. the late king of Denmark, pretenids to have found a 
third Egyptian burying-ground, fituated about fixty miles from a place where the Red Sea can now be paffed on foot without afcending above the mid.leg at low water.

It is very remarkable, that fo many Egyptian mo. numents fhould be difcovered in Arabia Petræa; and Mr. Niebuhr affures us that an entire Egyptian town is actually feen there, poffeffed of lands highly cultivated*, although never mentioned by any hiftorian. The inhabitants of Heroonopolis might have carried fome of their mummies about five miles beyond what is called Gibel-el-Mokateb, or the hewn mountain. But we have never underftood that the Egyptians ufed fepulchral ftones, fuch as Mr. Niebuhr calls Leichenfeine; neither is any thing of the kind obferved in the Elyfian fields, nor in the great burying-place between Sacbara and Bucbaris, on which the Greeks have fo ftrongly exercifed their imaginations. Cocytus, that formidable river, is now only a little canal, parting from the Nile and Lethe another ftill lefs confiderable. The Egyptians, we may fuppofe, preferred that place for their fepulchre, becaufe they wifhed to be interred near the pyramids. Thofe monuments, fo well calculated to embellifh defcriptions, and far more important than the ditches of Cocytus and Lethe, have never once been men-

- So viele fchone gebanene feine kannen ibrem urjprung, nicht von berum freifenden familien gebabt baben: fondern mufJen notbwendig von den Einwobnern einer groffen fadt berruhren. Und wenn in diefer jetze wuflen gegend eine groffe. ftadt geftanden hat fo mufs fie uberbaupt auch beffer angebauet gewefen feyn. "Befchrieb. von Arabien. 
tioned by the Greek mythologifts, although the great pyramids on one fide, and the fmaller on the other, are feen diftinctly from the Elyfian fields. We muft not however infer that they were built later than the days of Orpheus and Homer, becaufe thofe two poets are totally filent on the fubject.

The Egyptians do not appear to have ever poffeffed any writings afcribed to infpired authors; but the great colleges publifhed, under the fanction of Thoth or Hermes, whatever concerned religion; and neither priefts nor private perfons ever treated fuch matters in their own name. All books relative to jurifprudence, hiftory, and aftrology, were likewife confidered facred, particularly when compiled or calculated by the Pharaohs. Treatifes on aftrology, however, were not afcribed to Thoth, but to their real authors, fuch as Suchis and Piloftris; and to $\mathrm{Ne}$ cepjos, the great promoter of that fuperftition fo inherent in eaftern nations*. Kerim-Kan, the conqueror of Perfia, was accompanied in all his expeditions by aftrologers; and Alexander long before had provided himfelf in Egypt with perfons of that clafs, in the fame manner that pilots are taken for an unknown coaft. The fervices they rendered him by explaining an eclipfe of the moon very remarkable

- Some modern authors have confidered Necepfos as the inventor of judiciary attrology, becaufe St. Paulin fays,

Quique Magos docuit myleria vana Necepfos.

$$
\text { Apud Aufon. xix. Epirt. }
$$

But as judiciary aftrology isa folly more ancient than the days of this author, his teltimony cannot be held conclufive. 
in ancient hiftory, were very great, according to Quintus Curtius, but Arrian relates the whole affair in a different manner*.

Clemens of Alexandria has given us the contents of forty-two Hermetic books adopted by the great colleges. The firlt volume was of little importance, becaufe it contained nothing more than the pfalms of the Egyptians; but we have to regret the lofs of the fecond, where rules of corduct were prefcribed for the kings, concerning which we thall have occafion to fpeak more fully in the fequel. Unfortunately even no extracts remain of the eighth and ninth volumes of that collection, treating of cofmography and geography. Some authors have regarded the latter as the favorite fcience of the Egyptians; and yet their notions concerning it mult have been reduced to fome practical rules in compofing plans or maps. The Chinefe were incapable of performing even fo much on the arrival of the miffionaries; for they poffeffed nothing more than fcraps of paper containing fome characters placed to the north or fouth of a river; without indicating either the diftances or relative pofitions of places. The emperor Can-bi had to employ Europeans in compafing maps. of his own country, and thefe, after all, were fo imperfect, that in the year one thoufand feven hundred and thirty the latitude of Pe-kin was faulty, and the longitude very uncertain.

Had any treatife on cofmogony, written by real Egyptians, been preferved, we might be able to fpeak

* Curt. lib. iv. cap. 1o. Arrian, lib. iii. 
of that matter with more precifion. In this uncertainty recourfe has been had in vain to the pretended Hymns of Orpheus, the Theogony of Hefiod, and the Fragments of Sanchoniathon. Philo has endeavoured to render Phenicia in general, and particularly the town of Byblos, illuftrious at the expence of hiftory and truth, to the former of which he was a Atranger, and to the latter an enemy. The inventor of the Hymns of Orpheus, the moft expert of thofe pfeudonymous writers, has at leaft preferved fome few traces of the Egyptian doctrine, fo much disfigured by the Greeks, and moft of all by Plato*. They either did not underftand the language of that country, or tranflated badly, and by terms far from being fynonymous. The fame thing happened in the beginning of the prefent century with regard to the Chinefe, and -we know how many difputes have arifen about the real fignification of the words Tien and Chang-ti. It was then very ftrange to fee a Tartar endeavouring to reconcile all the theologitts by declaring, in direct contradiction to the decifion of the pope, that the Chinefe were not idolaters. But we may fuppofe that this man would have been much puzzled to explain clearly the nature of idolatry; becaufe, moft probably, he did not poffefs the fubtilties of thofe illuftrious Jewilh writers, who, like Abravenel, decided pofitively, that the different

- The dialogue betwcen God and Night, fuppofed to be written by Orpheus, has at leaft the fylle of the Afiatics. The Indians have another, far more judicious, where the Divinity is made to converfe with Human Reafon, 
kinds of idolatry were neither more nor lefs than ten. But in this calculation they furely forgot the eleventh, which confifts in ufury and clipping mo. ney; for who are more idolaters than the avaricious?

It muft not be believed that the Egyptians ever employed the term $T_{y p h o n}$ to fignify the evil genius, called in their language $S e t h, B a b i$, or $P a p y$, and very different from the Grigri of the negroes. Several fables concerning Typhon, who was faid to be always connected with an Ethiopian queen named Azo, tend to fuggeft that this mythological phantom came originally from the favages of Ethiopia, who had probably invented fome rude and noify inftrument to frighten away the Babi. In Siberia, along the coaft of Africa, and in the new world, as far as Terra del Fuego, many nations employ bells, rattles, and drums, or gourds filled with ftones, againft the evil fpirits. The favages frequently fancy themfelves befieged during the night by demons, and on the flighteft indifpofition they apply to the exorcifms of jugglers, who always make fuch a horrible noife, that the patient is entirely ftupified. As the Egyptians have always difcovered, we will not fay great conftancy, but aftonifhing obftinacy in preferving their ancient religious cuftoms, we may prefume that the inftrument ufed by the Ethiopians for driving away the Babi, was really the fiftrum, carried by each affiftant in all the Egyptian ceremonies. Bochart has even proved that in very ancient times Egypt was called the Land of Citherns, which were not, 
not, as we have already obferved, fuch inftruments as the celebrated muficians of Alexandria mentioned by Ammianus * could ever employ in their concerts. In the days of Plutarch the lower clafs of people in Egypt continued to believe that the noife of the fiftrum drove away Typhont, whofe power diminifhed in proportion as reafon advanced. The fame thing has happened in every country of the world; for mifchievous fpirits and hobgoblins are only formidable among favages and barbarians. Different monuments in the towns of Apollo and Mercury atteft that the Egyptians confidered Typhon as fubject to the power of the Supreme Being; and the facerdotal fables reprefented that monfter as drowned in the lake Sirbon, whither he was thrown headlong, after having been ftruck with thunder. It thould likewife be obferved, that he was always fuppofed to poffefs more influence on natural effects than in the affections of the human mind. To him were afcribed the burning winds, fo noxious in that country, as well as the fuffocating fogs around Pelufium; and it was he likewife who appeared in thofe water-fpouts on the Mediterranean, which are ftill known by his name.

Thus the Egyptians would feem to have been much more embarraffed in explaining the origin of phy fical than of moral evil. It is eafy to admit that beings fuppofed to be born free agents, fhould feek

* Ne nunc quidem in eadem urbe docirine varia filent. Non apud cos exaruit mufica, nec harmonia conticuit. Lib, 22.

+ Typhonem clangore fiftrorum pelli polfe credebant. , De Ifid. \& Ofirid. 
in themfelves alone the fource of vices and of virtues: even the vulgar are capable of conceiving this; but the convulfions of nature, fo far beyond the power of man, and deftroying alike the innocent and the guilty, differ greatly in their eyes from that phyfical evil which produces diforder in the paffions. After this, it is almoft incredible to find Mr. Fourmont, in his Critical Obfervations on the Ancients, endeavouring ferioufly to demonftrate that the Typhon of the Egyptians was no other than Jacob the patriarch of the Jews*. This chimera alone furpaffes all thofe of Huet, Kircher, and Warburton. The allegorical fables related by Plutarch feem indeed to indicate that the Egyptians confidered the Hebrews as a wicked and typhonic race. Thore allegories however were probably confined to the populace, and not extracted from the books of the priefts, in which, according to Jofephus, nothing more was found concerning the Jews than that they had been collected in Avaris, called likewife the Town of Typlon. The fituation of that place is very interefting for geo. graphy, and ftill more for hiftory; yet no perfon has hitherto been able to point it out with certainty. In our opinion Avaris is the fame town with Sethron, and its diftrict formed the leffer Land of Go/hen; for the Jews never inhabited the greater, fituated forty leagues more to the fouth, and belonging to a town called Heracleopolis Magna; while the little Land of

* Vol. i. lib. ii. cap. 15. 
Golhen formed part of the territory of Heracleopolis Parva, or Sethron in the Delta *.

The mythological victory of the gods over Typhon may in one fenfe be fuppofed to refer to the expulfion of the fhepherd kings, and in another to the drain. ing of Lower Egypt by canals. Prior to that undertaking the country was uninhabitable, and it is eafy to conceive that the fogs there mut have been exceedingly pernicious. Independently of the other caufes already affigned, as connected with the origin of the plague, it thould be obferved that the two chains of mountains bordering that country on both fides from the cataracts of the Nile as far as Cairo, form a long, deep, and narrow valley, where the air cannot circulate freely. Several elbows befides prevent the wind from following even a longitudinal direction. In the fame manner, from the narrownefs and irregularity of the ftreets of Conftantinople, the contagion is conftantly preferved, becaufe the current of air wants force to diffipate the noxious particles. The ancients pretended that in Egypt the

* The Egyptian priefts did not infert the real names of the ufurpers in their memoirs; but they denoted them by odious fym. bols. Cambyfes was the poignard; Ochus, the afs; and the firft of the Thepherd kings, Typbon or Seth. Thus Sethron, where they refided, had the name of the Town of Typhon, in the facerdutal books, although it was properly Gofen, or the leffer city of Hercules. The Thepherds called it Avaris, or Abaris; but after their expulfion it received again the name of Sethron or Typhonopolis, which are fynonymous terms. 
wind never defcended low enough to agitate confiderably the waters of the Nile; but they fhould have contented themfelves with faying that the veffels are there fubject to frequent calms. It is certain that, as Ariftotle afferts, the Nile had formerly but one mouth *: all the others were formed by human induftry, and increafed to feven, not without fome affectation of equalling the fuppofed number of the planets. But the Tanaitic mouth was never confecrated, as fome have believed, to. Typhon. The averfion teftified for Tanais proceeded merely from its having been inhabited by the hepherd kings. That place was always expofed to the incurfions of the Arabs, and at this day a horde of Bedouins feed their cattle in the diftrict called formerly the Little Land of Golhen.

As we have aimed at nothing more than to indicate thofe points in which the religion of ancient Egypt differed effentially from that of China, it is not neceffary to introduce long difcuffions on the panegyres, or folemn feafts. They were not fo numerous as we might be led at firft to believe, becaufe they were not celebrated by all the provinces at one time; and many are regarded as different, although they may have been effentially the fame.

* Meteor. lib. i. cap. 2.-Ariftotle believed, that the only natural mouth of the Nile was that of Canopus : but in very ancient times the river difcharged itfelf at the point of the Delta, about thirty leagues more to the fouth than Canopus. This appears credible on infpeeting the face of the country. 
The feaft of bludgeons, held in the autumn, was pro. bably no other than that witneffed by Herodotus at Papremis in the Delta, where the devotees fought with clubs, or poles; but, as he affures us, without the lofs of any lives. Thus that folly, however great and reprehenfible, could not be compared with the combats of the gladiators in Italy. The feftival in the beginning of the dog-days feems to have differed little from that of the lamps in the town of Sais; and finally, what the Greeks called Niloa, and the Romans the birth-day of Apis, coincided exactly with the feaft folemnized at the fummer folftice, as we learn pofitively from Heliodorus. Egypt then offered the gayeft fpectacle in the whole year; for thofe who were naturally gloomy and thoughtful made at leaft great efforts to furmount their melancholy. Mr. Niebuhr obferves, that the modern Egyptians, even when moft defirous of appearing joyful, are never fo in reality. They feem indeed to have difcovered the fame difpofition in former times, although the priefts neglected nothing to render the theophanies and panegyres fo very amufing, that they were called by Ovid the Delights of the Nile. Ancient phyficians, who prefcribed a voyage to Alexandria for their patients, furely did not hope for any advantage from the air of that place; but they were led to expect much from the diverfity of ftrange objects and public amufements fo numerous in Egypt, but too frequently accompanied with the groffeft debauchery. Yet, whatever Juvenal 
Juvenal may have advanced *, we cannot believe eafily that the indigenous inhabitants always carried diffolutenefs to fuch excefs as the Greeks of Canopus, who feem to have been unequalled in the world. Polybius affures us, that in his time Alexandria contained no other decent people than the native Egyptians, and they did not amount to one third of the inhabitants. The reft confifted of a nixture of Greeks and Jews joined to the refufe of all the different countries of Europe and Afia.

Befides the fabbath, which the Egyptians feem to have obferved very regularly, they had a fixed feftival at each new moon; one at the fummer, and another at the winter folftice, as well as at the vernal and autumnal equinoxes. All others, except that on the rifing of Sirius, were changeable, and dependent on certain combinations known to the priefts only, who transferred them arbitrarily, whenever they occurred on the neomenia, the equinox, or the folftice.

No modern author has ever been able to explain why the priefts of Egypt adhered fo obftinately to the uncertain year in matters of religion. They even exacted a dreadful oath from all their kings, previous to inauguration, never to abolifh the imperfect year, which was too thort by five hours, forty-eight minutes, and thirty-feven feconds $t$. The Jews, who

$$
\text { * Horrida fañè }
$$

Agyptus; Sed luxuria, quantum ipfe notaqi,

Barbaro famofo non cedit turba Canopo.

+ The priefts of Egypt inferted an extraordinary day only on each fourth, fixed, or facred year. 
were the worft aftronomers in the world, exceps perhaps the Chinefe, held at times a fecret council to determine, whether or not they thould add a month to their lunar year. To this affembly neither the king nor the high-prieft could gain admiffion, becaufe, as it was the intereft of the latter to prevent, and of the former to effect, an intercalation, both their votes appeared fufpicious *. The fovereigns of Egypt were probably in the fame fituation; and the priefts did not forget that when five days were at one time added to the year, the Pharaohs, as Plutarch fays, infifted on having one entirely for repofe. Befides, the facerdotal order pretended to the exclufive right of compofing the almanacs; and they alone were capable of the tafk, as long as the year remained uncertain. The inconveniencies this occafioned in civil life were however very trifling; becaufe every thing belonging to agriculture and the overflowing of the Nile was exactly regulated by fixed feafts, which indicated to the people each new moon, equinox, and folltice. It was from Egypt that Greece and Italy received the only tolerable calendars they poffeffed. Lucan reprefents Cæfar, after having fupped with Cleopatra, as boating that the Julian year thould cede in rothing to that of Eudoxust. It is not however very probable that any

* Mor. Maimonid. de Confecratione Kalendar. \& Ratione Inter. calandi.-The kings of Judea might in certain cafes have had an intereft in making the year confift of thirteen months; and it is right that fuch matters thould not depend on the will of any clars of men.

+ ITec meus Eudoxi vincetur fafilbus onsus. 
man fhould think of fuch matters at table with Cleopatra : befides, Eudoxus had ftudied in Egypt; and as Cafar employed an. Egyptian, he could only value himfelf on his good inclination.

We fhall terminate this article by fome obfervations on the pretended zeal of making profelytes, attributed to the Egyptians. This opinion is founded alone on the numerous temples in different countries where divine worfhip was celebrated according to the Ifiac rites by thorn priefts clad in linen, whole probity was very doubtful; but the real Egyptians never took any pains to make profelytes, and the worfhip of Ifis was propagated in the illands of the Archipelago, at Corinth, 'Tithoræa, and almoft every town in Italy, by Afratic Greeks, who received Neophytes without fubjecting to circumcifion, although in Egypt that operation was confidered as indifpenfable. Some temples of Ifis, like that of Bologna, might have had fixed revenues, becaufe they were founded by Roman families or rich freedmen; but the greater part had only begging priefts, who knocked at every door with their fiftrum, and perfuaded the common people that no crime was fo enormous as that of - refufing them charity *. This evil foon arrived at its height in Italy, where all exertions of the police to check it were ineffectual; for the meafures taken by the fenate and the emperors againt the worhippers of Ifis were equally abfurd with thofe they had employed to extirpate the Jews and aftrologers.

* Ecquis ita eft audax, ut limine cogat abire Acantcm Phariâ tinnula ffitra manu? Orid. de Pont. i. 
Vie do not, however, mean to deny that in the reign of the Ptolomies fome real Egyptians might have been found both among the vagabonds already mentioned and the Galli; but they were always of the dregs of the people, who, perfecuted at home by poverty, had no other refource than the credulity and fuperfition of mankind. 


\section{S E C T. VIII.}

ON THE RELIGION OF THE CHINESE.

7 HOSE who have endeavoured to eftablif fome L order among the different religions known in the world fince its creation to the days of the emperor Auguftus, have agreed to r-duce them to three. claffes: Barbarifm, Scythifm, and Hellenifm. Without examining here whether or not that circle is fufficiently extenfive to comprehend every fpecies and variety, we may obferve that a particular clafs might well have been allotted for the worthip introduced into favage countries by the Scythians or Tartars. It is now no longer doubtful that the religion of the ancient Chinefe was a branch of Scythifm, adapted to the character of a rude, reftlefs, wandering, and paftoral people: nothing, however, could be more unfit for a peaceable and polifhed fociety. Thus the Tartars, even when capable of preferving their conquelts, always abandoned their religion, and China for the fame reafon adopted the Indian worhip : yet that country, fituated at the extremity of our continent, and feparated as it were from the reft of the world, fhould have adhered more than all others to its na. tional inftitutions; but they wanted force.

Leibnitz inagined that the $r$.King, which is, undoubtedly, the moft ancient monument of the Chinefe, contained the elements of hinary arithmetic.

The conjecture, however, of that great man was by far too ingenious; and it is furprifing that he, who 
knew the hiftory of the ancient Germans, fhorld not have perceived that they likewife have their $Y$ King.

With them, as well as with the Chinefe, it was nothing more than a table of chances; and we have every reafon to believe that the fame fpecies of divination was practifed by the Scythians. That of the Chinefe contains fixiy-four marks, compofed of ftraight lines, fome of which are whole and others broken. The perfon who confults Fortune, throws forty-nine fmall rods at ranciom on the ground, and their fortuitous pontion, accordingly as it correfponds with the marks of the $r$. King, indicates good or bad auguries. Confucius, by writing the greater part of the rules for this forcery, has injured his reputation irreparably, not only in the eyes of philofophers, but of all thofe who can read without frejudice the hiftory of China. With regard to the Germans, we are informed very minutely by Tacirus of their throwing rods in the fame manner wilh the Chinéfe *; and we have already had occafion, in ano: er $^{*}$ work, to thow that this was the origin of the word Buchfaben, which is ftill ufed, although in a very diffurent fenfe.

- The mode of throwing the runes, pracifed by the other Scythian nations in the north of Europe, is exactly conformable to what is feen in the fourth

Tacitus fays, that among the Germans, whowere originally Scyth ians, the prototype of rhabdomancy was engraved on rods and we thall find that the Chinefe alio fometumes had rods with inferiptions. 
book of Herodotus*, where we find that the Scythians had no other mode of divination than that employed in the greater part in the pagodas in China. The prototype of rhablom incy is there fixed againft a wall + ; and Forture is co fulted in the manner we have defcribed, without any more relation to binary arithmetic than to algebra. Although Mr. Leibnitz kept up a correfpondence with the Jefuits of Paris, they never informed him that the T.King was enployed by the Chinefe for no other than reprehenfible purpofes. Had that philofopher been as well informed as we now are of thofe matters, he would have changed his opinion; for no perfon was ever lefs inclined to feek reality in vain fuperftitions. When he undertook to defend the Chinefe againit certain imputations, he acknowledged candidly that none of their books difcovered any true notion of the creation of the world $\ddagger$. This certainly weakens their deifm; for thole people are far from being

* Herodotus indeed afferts that hermaphrodites were found in Scythia, who ufed leaves of trees, in divination; but an entire treatife would be neceffary to explain who thofe men really were, and what was their manner of divination by leares, which feems not to have been unknown to the Chinefe. Many circumftances relative to the rhabdomancy of the ${ }^{-S}$ cythians and Medes are found in Dio. lib. i. Tertiæ Compofitionis.

+ In fome pagodas thefe rods are flat, about fix inches long, and covered with characters; others contain different kinds, fuch as we find defcribed by Merdoza, Hiftoria della China, lib. ii. cap iv.

I In his Collection of: Letter3, and the notes he has added to the Treatifes of Langubardt and Antuine de St. Marie. 
deifts, who do not admit the Eternal to be the free creator of the univerfe, and, as Newton expreffes it, the Mafter of Nature.

When Father, Merfenme afferted in one of his publications that he knew twelve atheifts in one houfe at Paris, and that the whole number in that city amounted to fixty thoufand, the police, by feizing all the copies of the work, quathed this grofs calumny of a begging cenobite who lived at the expenfe of the public; but no fuch precaution was ufed againft the treatife of Langobardi, another monk, who did not accufe fifty or fixty thoufand perfons of atheifm, but the whole class of the litcrati in China. An imputation of that nature was too atrocious to proceed from charity; and the more atrocious it was, the ftronger proofs we ought to have had of its truth: yet nothing was ever lefs clearly, demonfrated. Thefe pretended men of letters are exceedingly ignorant; and when in their difputes they no longer underftand each other, which frequently happens, they trace out with their fans the characters of the word intended to be explained. Never, in fhort, was any language more unfit for metaphyfical difcuffions than that of China, and it is called among the neighbouring ftates the Tongue of Confufion. Rules of grammar and fyntax, invented to render languages diftinct and intelligible, are unknown in that jargon; it confifts of no more than three tenfes, and about fifteen or fixteen radical words, not one of which is fynonimous with God, Creation, or Creator; and the more circumlocutions are introduced, the greater, 
of courie, is the perplexity. If, under fuch circumftances, fome of the literati feem incorrect in their notions concerning the effence of the Divinity, it does not follow by any means that they mult be atheifts; and their very fuperftition argues the contrary. This is explained in the cleareft manner by the following paffage extracted from the work of Father du Halde :

"The moft able of the Chinefe doctors are igno. rant in general of all parts of philofophy, if we except a little morality. They are incapable of reafoning with any juftnefs either on natural caufes and effects, or on the foul, the Firft Being, the ttate of another life, or the neceffity of a religion, concerning all which they feem very indifferent. No people, however, apply more time to ftudy than they; but their youth is fpent in learning to read, and the reft of their life in fulfilling the duties of their employments, or in compofing academical difcourfes. This total ignorance of nature is the reafon why the mof commoni effects of nature are always attributed to fome evil genius *."

It would be unjuft to require that fuch men fhould fpeak and write like philofophers or metaphyficians; and furely, in them, fuperftition is more remarkable than atheifm. Befides, when it is faid that no idea of the creation of the univerfe is found in the Chinefe books, we muft confider the affertion as limited to thofe compofed before the thirteenth century. Under

* Defcription of China, vol. iii. 
the dynafty of the Moguls, fome authors, fuch as Hou-ping, fpoke of the origin of the world nearly in the fame manner as the Mahometans.

Next to the $Y$-King, or table of chances, in the canonical order, fome place the Cbou.King, which is not an original and complete work, but an imperfect collection of hiftorical occurrences, common-place moral fentences, and various fuperfitions. The compiler of this piece, which deferves the name of a rhapfody more than cither the Iliad or Odyffey, is not known; but he evidently lived at a period much later than the events recorded in his work. As the Cbou-King, it is faid, was not compiled until the days of Herodotus, it muft always be impoffible to afcertain how mucl has been added or retrenched by thofe who collected the different pieces; and the whole production appears very doubtful in the eyes of good critics, when they refiect that it was at one time committed to the flames, and afterwards compofed anew : yet fome traces of antiquity are found there, and it reprefents the Chinefe, like the other Scytbians, as much addicted to intoxication with $\int a m p \int u$, particularly in the northern provinces, where they, firft fettled. That name is given to a fpirit extracted from rice, millet, or wheat, and even from buck-wheat, as fome pretend, although that grain muft certainly have been brought into China from fome other country. The vine is likewife confidered as an exotic by travellers, who pretend that it was introduced there fince the time of Confucius.' This, however, is very uncertain; and we only know that anciently, 
anciently, as at prefent, the Chinefe never preffed any liquor from the grape. Their method of obtaining a fpirituous drink froin rice was nearly fimilar to that practifed by the Tartars in diftilling the milk of mares. The Chou-King mentions nothing concerning tea; and we are ignorant of the precautions taken in thofe days againft the bad quality of the water. The ancient Troglodytes employed an infufion of the rhamnus paliurus, which might be very effectual in rendering the bitter waters of Arabia potable, and perhaps its properties in that refpect are fuperior to thofe of the tea-tree.

It is not eafy. to give the rcader an idea of the whimfical manner in which fome matters of natural philofophy are treated in the Chou-King. The com. piler not only introduces the five elements, but he afferts that each has a particular tafte: thus, according to him, every combuftible matter is bitter, and every thing fown and reaped is fweet; to prove which he fhould have cited multard and coloquintida. It is difficult to conceive how any refemblance could be found between fuch abfurdities, and the treatife of Ocellus Lucanus, who befides was a very inconfiftent reafoner, as we perceive by his two arguments to prove the eternity of the world. He indeed was not the inventor of that fyltem; but no perfon could have defended it more feebly.

The ancient inhabitants of Afia erred chiefly in what concerned natural philofophy: But the expreffions of the Chou-King concerning forcery are diametrically 
trically contrary to common fenfe; and that the reader may judge, we need only copy one paffage:

If the grandecs, the minifers, and the people; fpeak in one minner, and you think otberwife, but conformably to the figns of the Tortoife and the Cbi, your advice will fucceed.

If the grandces and the minifters are united in fentiment with the Tortoije and the Chi, although you and the people differ from them, every thing will fucceed equally.

If the people, the Tortoise, and the Chi, are unani. mous, when you, the grandees, and the minifters, bave another opinion, you may be fure to fucceed interiorly, and fail outwardly.

If the Tortoife and the Chi oppose the counjels of men, it is wife to undertake notbing; for evil alone mift bo the confoquence *.

The firft idea fuggefted by this paffage is; that the compiler of the Chou-King was a Chinefe madman. But as the bad cuftom of interrogating the oracle of Delphi on every fubject, public and private, did not prevent the Greeks from becoming polithed and flourilhing, neither were any ill effects produced by the fuperftitions we have mentioned on the peafants or artifts of China. When enlightened princes and able minifters appeared in that country, they allowed themfelves to be as little impofed upon by the Tortoife as the Roman fenate by the facred chickens, or the Areopagus: and Amphyctionic college by the

- Chou-King, part ir. chap. 4.

Pythia. 
Pythia. Yet it were to be defired that the minds of the Chinefe could be divefted of fuch chimeras; for although they do not affect materially the body of the itate, yet ftill, among the common people, their effects are frequently melancholy.

In a well-regulated country fome means might be devifed of making the blind fubfift without begging or telling fortunes. The multitude of fuch wretches, who ank alms in China, is aftonifhing; and they have acquired by their foolifh predictions fo much in. fluence on the minds of the people, that their agency was employed in propagating the dogmas of the Catholic religion. As long as fome rich Neophytes paid them bountifully, they continued to recommend baptifm to all thofe who applied for their advice on futurity. The government might eafily prevent the monks from exercifing their forcery with rods in the pagodas; but thofe who have feen the almanacks printed by direction of the pretended Mathematical Tribunal, and filled with the moft abfurd fuperftitions, are convinced that the Chinefe have no inclination to open their eyes on the abufes. which difhonour them in the eighteenth century.

It would be fuperfluous to enter into extenfive details concerning the other canonical books, or Kings: that called the Spring and Autumn is nothing more than a fingle chronicle of the princes of Lon, and China contained at one time about one hundred and twenty. fuch kingdoms; but difcord, which nothing can withtand, fwept them all away amidt ftreams of blood. Thofe fmall ftates waged conti- 
nual war with each other, like the Aymans or Tartar hordes; and the manners of the Chinefe were then perfectly fimilar to thole of the Scythians. Even their princes drank out of human fhulls, after having taken off the fcalps, in the barbarous manner defcrited by Herodotus, and ftill practifed by the favages of North America. The Cbi-King is a collection of verfes, many of which, according to the confeffion of the Jefuits themfelves, are extravagant and impious*. It is, however, curious to obferve in the Cbi-King an ode on the Ruin of Mankind, afcribing that nisfortune to a woman, and announcing the fpeedy deftruction of the world. This adnits of no medium: either the piece has been compofed at fome recent period from Rabbinical ideas, or the author, confidering the Chinefe nation as the whole human race, alludes to the miftrefs of fome wicked prince, who, through weaknefs for her, had difmiffed the magifurates, and given their places to rogues. It is very commion with the Chinefe authors to com. plain of the numerous, but not unexampled, misfortunes occafioned to the ftate by the blind paffion of fome emperors. Another ode in the Cbi-King defcribes the dreadful diforders introduced by $P a 0 . / \int e_{\text {, }}$ the miftrefs of Teou, a prince configned to the execration of all ages, and commonly ftyled the King of Darknefs : yet thefe facts do not prevent the Cbi-King from appearing to be a very doubtful performance, not only on account of the articles rejected by the

* Du Halde, Defcription of China, rol. ii.

Jefuits, 
Jeftits, but from the whole collection; and as much may be faid of the Li-ki. But the palfion of the Chincle for the number five made them determined, at all rifks, to have five canonical books to equal their five elements, and five manitons, which, according to them, prefide in different parts of the $\mathrm{ky}$ under the direction of the Supreme Genius. Confucius maintained that the even numbers, two, four, fix, eight, and ten, were terreftrial, rude, and imper. fect, while the uneven numbers, one, three, five, feven, and nine, are celcftial, particularly the two laft. It is eafy to perceive that this prejudice, altogether unworthy of a philofopher, had infected a great part of Afiatic and European Scythia many ages perhaps before the birth of Confucius: fome traces of it are found not orly among the Getre, the Lamas, the Moguls, and the Calmuks, but likewife among the favages of Siberia. The firft tribute of furs required from the Samoides by the Ruffians, under the czar Bafil Ivanowitz, was brough to the receivers diftributed in nine facks. It ftruck me inmediately, when examining fome infcriptions found in Lapland, that the fame myftic number very frequently occurred in them alfo; and this is not furprifing if the Laplanders are really defcended from the Calmuks or Huns, as fome endeavour to prove by analogy of language *

* The characters found in Lapland are traced in this manner: ]11XXX $111 .+\dagger+111 \mathrm{XXX}$.

This formula is repeated ieveral times in different places, and gives always twice the number nine. Knud Leems, Profeffor der Lappifchen Sprache, Nachrichten von den Lappen.

What 
What is called the ancient religion of China has now no prieft or clergy, if we except the prince, who unites in his own perfon all the facerdotal and imperial authority. Thofe who form the Tribunal of Rites are neither confecratcd nor capable of offering great facrifices; and the emperor at pleafure orders them to be chaftifed like flaves, or difmiffed entirely, to mingle with the crowd of common men. When the eunuchs governed the empire, the Tribunal of Rites was compofed entirely of fuch mutilated wretches as themfelves. Defpotifm in fact has over. turned priefhood in China, and trampled it under foot; for, in former times, the Chinele had certainly their priefts, as well as all the other nations of Scythia. The Kans indeed always poffeffed the right of offering certain facrifices, and immolating particular victims, from which they probably were firft called Sons of Heaven; and the title, Tanjou, of the Calmuk princes refembles greatly the Tien-tfe preferved by the emperors of China. All matters of religion were not, however, totally engroffed by the Kans: thus we find that the Moguls and Mandhuis permitted the Kutuktus to retain fome part of their authority; and they continue to follow the great hordes when they lodge near the tent of the prince. They refide likewife at the court of Pe-kin; becaufe the religion of the Iamas is profeffed by the Tartars, who, in one thoufand fix hundred and forty-four, fubdued China. Many centuries before that conqueft, the total extinction of the priefthood had made the Chinefe entruft the fuperintendence of public educa- 
tion to the magiftrates; and fome modern writers have beftowed the highef encomiums on that meafure: but as the country contains many different fects, the magifrates of the provinces, having no uniform religion, may eafily be led to enforce their particular opinions relative to $F_{0}$ and Lao-kium. "It is truly ridiculous to fuppole that little mandarins are never the dupes of the feduction practifed by the bonzes, who have fo frequently acquired an afcendancy over the whole court, and fometimes to fuch $\mathbf{3}$ pitch, that we find the emperor Kan-tfou defcending from his throne to become a novice in a bonzery. When any country has an uniform worfhip, the beft method of giving all pofible force to public inftruction there would confint in entrufting it alternately to the magiftrates and the clergy, according to invariable formularies adopted by theftate. This would prevent continual and bitter complaints againft wretched preachers; for they muft then become all equally good.

China had in former times a high prieft, called Tai-che-ling, whofe power diminifhed in proportion as that of the emperor increafed. This revolution, added to many others, enervated to fuch a degree the national religion, the dogmas of which were very ill connected, that it became neceffary to introduce a foreign fyftem from India. Unfortunately the newly-adopted worfhip was no longer in its primitive purity; for $F_{0}$ or $B u d b a$, having blended with it the corrupt doctrine of repofe and meditation, gave rife to monkifm, or rather to that fcourge, concerning which we thall fpeak more particularly hereafter.

The 
The Chinefe would have acted more wifely by adhering to the ancient minittry of their Tai-che-ling, than by abandoning themfelves to the lazy and covetous race of the bonzes, who are unconnected with the conftitution of the ftate. Whether they ber or poffefs lands, fuperftition is to them always equally neceffary; for they find it as effectual in preferving as in acquiring riches. The Chinefe, prior to the introduction of Foifm, had indeed other monks, who followed the ancient fect of Immortals : they are mentioned by Herodotus as well as Plato, in whofe time they were fcattered in the north of Greece, and thence introduced by the Getæ into Wallachia and Moldavia. It is not aftonifhing that the Chinefe thould be incapable of inventing a mode of worfhip adapted to the genius and morals of a civilized people; but they made the worft choice poffible among all the religions of their neighbours*. In thofe days the fuperfition of the Parfis were preferable; particularly for a poor nation, to thofe of Foifm; becaufe they admitted no monks, and their dogmas were favorable to agriculture. Thus the princes of Afia, by receiving them into their dominions, had never any caufe for repentance; and it were to be defired that the fame thing could be faid of the Jews in Europe, who have the more occafion to be reform. ed by others, as they are averfe to it themfelves, and

* Some hiftorians pretend that the emperor Ming-ti was led to introduce the Indian religien into China from an apparition and a prophecy of Confucius. Such fables are too grofs ever to be admitted. 
continue to practife ufury as in the days of Mofes. Although the Indian worhip was much corrupted when introduced among the Chinefe, it contained ftill fome inftitutions very proper to correet the natural ferocity of a Scythian people. The innovator $B u d b a$ had not diminifted the horror for bloodhed which characterifed the dormas of the Hindoos, who, on that account, are pardoned, or at leaft not re. proached, for many of their fuperftitions. The bonzes even endeavoured to abolih the punifhment of death in China, without perceiving that it could hever be difpenfed with in a defpotic Rate; for no. thing is more variable than the will of princes on a tottering throne. The advice of the bonzes produced fo little effect, that it did not prevent even the innocent relations of criminals from being conftantly dragged to the fcaffold, except the women, who are fold for flaves according to a maxim of the Scythians mentioned by Herodotus *: Some of their colonies brought the fame cuftom into Ruffia, where it ftill continues.

The ancient religion of China confifted chiefly in facrifices offered on the hills, whither the emperors repaired with the high prieft, and both moft probably immolated victims. In the province of Chan-tong is a mountain, called Tai-chan, fuppofed by fome of the Chinefe to be the higheft in their country, and tradition, as well as hiftory, informs is that its

- 2uos morte rex afficit, corum ne liberos quidem relinquit; fed wniverfos mares interfucit, faminis nil laffis. Herod. lib, iv. 
fummit was long appropriated to facrifices. What is faid of the inferiptions found there appears very fulpicious; though it is not impoffible but fome may be found there fimilar to thofe prodigious nones reared by the Scandinavians on feveral high fpots of northern Europe, and fometimes engraved with Runic and Laplandith characters. The latter are cut on pillars placed on the top of fome elevated rock, where fragments of bones fcattered round prove that facrifices have been offered there for many years by the Laplanders - a circumftance which certainly does not weaken the opinion of thofe who confider the Laplanders as defcendants of the Huns; for the place is ftill known where the latter immolated victims on a mountain in the province of Chen-fos Other places have been feen by travelters in Tartary and Siberia confecrated to fimilar religious ceremonies; and they feem, indeed, to have been geveral among the Scythians, to whom the Chinefe undoubtedly owe their origin. The name of their chief prieft related probably to the facrifices on the high places; but the great difficulty is to know what kind of divinities were addreffed in that manner. The theology of the Chinefe has filled heaven and earth with genii, among whom the Oreades, or thofe of the mountains, hold a very diftinguifhed rank, and ftill receive divine hohors. All the moft celebrated pagodas of the whole empire are alfo fituated on the moft elevated mountains* : men who had neither

- New Memoirs on the prefent State of China, rol. $i$. 
rowns nor fortreffes, and yet, like the favages of cold countries, were conftantly at war, wight frequently have found falety on the high grounds, after having been defeated in the plains. It was therefore natural that they fhould chufe fuch alylums for approaching as near as poffible to heaven to reiurn thanks or invoke future favors. Local divinities were infenfibly fixed on the mountains, and to them the blood of victims was offered, which had before been referved for the $\mathrm{ky}$. The invention of genii, or the phantoms fo called, feems to have followed the worfhip of the fars and the firmament.

When Father le Comte maintained, in his Memoirs, that the Chinefe had honored the Creator in the moft ancient temple of the univerfe, the Sorbonne, alarmed without reafon, condemned the affertion*. Yet it is difficult to conceive how the Sorbonne could pretend to decide on that point; becaufe it was merely an hiftorical fact every way unconnected with the religion of France. Hiftorians and philofophers thould be allowed to judge of fuch opinions, and then it would have foon appeared that the affertion of Father le Comte was fabulous, and not heretical. In the moft diftant ages the Chinefe had no temples, and they facrificed, like the other Scythians of Afia, on the mountains. As Mr. Leibnitz could not perceive in all their books, written long after they became

* Cenfura facultatis theolog. Parif. lata in propofitiones excerptas ex libris: Memoirs on China-Hiftory of the Ediet of the Emperor Can-hi-Letters on the Ceremonies of the Chinefe. 
polifhed, the flightent trace of the creation of thie world, it is eafy to conceive what mult have been thic ftate of their ideas while they remained favages. Their barbarifm was very great until the year or'e thoufand one hundred and twenty-two before our era, when a conqueror, called Vout-vang, at the head of two or three thoufand men, took poffeffion of China: he made fome laws, and endeavoured to fix the inhabitants, who were ftill fond of an ambulatory life, and frequently removed whole towns, confifting of portable theds and tents. Their hiftorical know. ledge was then nothing more than forne traditions concerning the ancient Kan Fonbi, whofe mother conceived him miraculoufly; he had no father, according to the mythologifts of China, who muft have copied this fable from the Scythians. They likewife pretended to be defcendants of a girl, who brought forth fupernaturally a child called Scytba, according to Diodorus Siculus. Herodotus difputes her virginity, and fufpects her having been connected with Hercules, whofe name is never mentioned in the fables of the Scythians. Both thofe authors, however, agree on the monftrous figure of that woman : her body below the breaft, fay they, refenrbled a ferpent; and the Chinefe pretend exactly the fame thing of Fo-bi*

- Father de Premare, who was indefatigable in his refearches concerning Chinefe mythology, informs us that an author named $V_{\text {en-t }} \mathrm{fe}$ pretends that $F_{0}$-bi had the body of a ferpent; with regard to bis father, he adds, the Cbinefe fay be bad none, for bis mother coit. - ccivad Lim niraculoufly. Preliminary Difcourfe to the Chou-King. 
The great analogy between thefe traditions proves that they were taken from one fource; and if we obferve befides the conformity of the emblem of the dragon carried by the Chinefe and Scythians on their ftandards, little doubt can remain of their having originated from a common ftock. The firf tlags of the Chinefe emperors, fixed like fails to their chariots, fwelled in the wind in the fame manner with thofe of the Scythians defcribed by Arrian *.

It is faid that the firt religious fymbol invented by the Chinefe was a tripod, or, to fpeak more intelligibly, a great vafe fupported by three feet, and furnifhed with two handles, fuch as are delcribed by Homer, or in the verfes attributed to Hefiod. This refemblance of the Chinefe tripod to that of Delphi can be accounted for only by adopting the tradition fo common in ancient times, that the temple of Delphi was founded by Scythians, named Hyperboreans. They received that name from inhabiting to the north of the mountains of Thrace, where the fouthern Greeks had placed the fource of the wind

* This paffage is already indicated in the preface; we now infert the Latin tranflation :

Signa Scytica Junt dracones convenienti longitudine pendentes ex contis. Fiunt autem ex pannis inter fe confutis, diverfi-coloribus, copite, reliquoque corpore onini ad caudain ufque fimili ferpentibus; in fpeciem maxime formidabilem, quantum poteft, infructo. Utuntur anten bis fopbifmutibus; quando quietifant equi, nil amplius quam pannos videas diwerfi-colores ad inferiora dependentes: quando vero currunt, inflati iurgefcunt in tontum ut ipfas quoque feras species referiant, ТАCт. 
called Boreas; and thus all the little nations beyond Thrace were to them equally Hyperboreans. Others towards the Alps and $\mathrm{P}_{\mathrm{y}}$ renees received allo that epithet, and it was they who mutt have facrificed affes, and carried into Greece the firft olive plants, which were certainly not rrought from Sais in the Delta. Even admitting that the Scythians really founded the temple of Delphi, faid by Paufanias to have been at firft a paltry hut, its worfhip was certainly altered afterwards, and mixed with many Egyptian cuftoms. The wolf, we find, was confecrated there to Apollo exactly as in the great Lycopolitan prefectory in Thebais.

The ancient Chinefe, it appears, were far from. being contented with one myfterious vafe; for, by degrees, they added eight others. To them was attached the fate of the empire, divided at that time into nine provinces, each of which had confequently its own talifman. This whimfical fuperfition could have originated only from the kettles firft employed in boiling the victims; and thofe of the Scythians, we know, refembled, except in fize, the bowls of Lefbos. Afterwards the vafes themfelves were revered, becaufe the genii or manitous, it was fuppofed, lodged there to tafte the meat; and the Chinefe, like all the Tartars, offered them the flefh of horfes. Their other victims were dogs, fwine, fowls, theep, and oxen: but fuch facrifices could no longer be continued when the emperors adhered ftrictly to the religion of India, which does not, in any cafe, permit 
the flaughter of animals *. It is only fince the eftablifhment of that worfhip that the Chinefe have ceafed at times from butchering camels, cows, and horfes; yet the people eat them when they die of old age, or even of diftempers, as is the cafe every day in Pek-in and Canton, without any meafures being taken to prevent this abufe, which is fufficient to occafion epidemical diforders. Extreme want would feem to have made them furmount the natural averfion of mankind to fuch food; yet, while famine frequently carries off great part of the populace in the towns of China, the mandarins feaft on the nefts of certain birds, on the tendons of deer, the fins of tharks, the feet of bears, Molucca mufhrooms, fwalofs, and every thing they can imagine mort gratifying to their tafte,

After the confecration of the nine myftical tripods, a prince, known by the name of Vou-ye, erected another idol reprefenting the genius of the $1 \mathrm{ky}$ with a human form, as we find in a memoir fent by Father Amiot to Mr. de Guignes $f$. This however feems little probable, becaufe the ancient Scythians never introduced ftatues in their religious worhip; and our fufpicions are increafed by the odd circumftances he relates concerning that image. According to him, it was an automaton employed to play at chefs or draughts

- During the reign of the emperor Kao-tfu no vietims were immolated at the great facrifices. That prince ordered figures of pafte to be fubftituted for animals ; but this cuftom, ftill more advantageous for the Chinefe than for the Indians, has fince been abolifhed, and butchers are again employed at the facrifices.

+ Inferted in the Obfervations on the Chou-King, 
with difgraced courtiers; and whenever they failed to win the game, as is generally the cafe, he adds, they are maffacred immediately. This ridiculous far ble is founded perhaps on a cuftom fumilar to that mentioned by Herodotus, as practiled by the Scythians on thofe who were accufed of having fworn falfely by the throne of their king. 'l'o be condemned, or' acquitted, they forced the augurs to play among themfelves at a kind of divination by lot; and thofe who loft were-inhumanly put to death, unlefs they all agreed that the perfon was culpable of the falfe oath laid to his charge. Befides, we perceive in that ufage the immolation of human victims, offered un. der pretext of prolonging the lives of the kings when fick; and fuch is the origin of thofe acts of felf-facrifice, of which fo many examples are cited in the hiftory of China.

Among thofe people, properly called I/fedons, fome of: whom inhabit to the fouth of the Oxus, and others in the country of Igour, animal facrifices are performed to anceltors, and offerings made to the dead. The Chincle at all periods practifed the fame ceremony; and they appear to have had their mias, or places where they feed fouls, prior to their having. any temples. That fuperfition was an effential point of their rites and worhip; but the great mourning has very wifely been abolihed by the Mandhui Tartars*. It lafted three years, and during that time

* The Tartars have reduced the great mourning to feven days; but on their fide they have fallen into another excefs, by augmenting the expence of funerals, where they cat and drink like the Scythians, and more particularly like the Getæe and the Iffedons. 3. ?: 
fon was obliged every day to place rice or fleth meat before his deceafed father. No public affairs could be tranfacted by the mourner; and if he had the misfortune to lofe his mother at the fame time, the ceremony continued for fix years; and if to this fucceeded the death of an only child, or an elder brother, the greater part of the perfon's life was fpent in appearance of fadnefs and real inaction. Never was any cuftom more pernicious and irkfome to fociety, or lefs neceffary for the dead. Such doleful and fatiguing inftitutions have influenced fo ftrongly the character of the Chinefe, that they are forced againft their inclination to have recourfe to extravagant tricks of every kind for momentary relief. It is with moral as with phyfical diforders, contrary qualities ferve alike in both to promote a cure. This fingular difpofition has by degrees filled the empire with people who cannot be called comedians, for they are really nothing more than rude buffoons, only capable of amufing men releafed from fix years of deep mourning. What the Jefuits have written concerning the regularity of the Chinefe theatres, has been contradicted by modern travellers, fuch as Orbeck and Torten, who are far from efteeming their farces. M. de Bougainville, after having been prefent at fome of their reprefentations, while at Batavia, contents himfelf with faying, that he never wifhes to fee again any thing of the kind *. That judicious writer feems

to

* "Befides the principal pieces reprefented on the theatres, fach clufter of houfes in the Chinefe quarter has a kind of ftage, where 
to have obferved that the Chinefe cannot difpenfe with their mountebanks; and this neceffity arifes, as we have faid, from the long duration of their gloomy rites. They were not indeed always exactly the fame, but the changes which have taken place tended lefs to foften than increafe their feverity; for fuch is the common courfe of fuperftition.

In former times no offerings were prefented to the fmall tablets engraved with the names of the dead: but a child was made to eat and drink in the name of the manes, until he called out Pas, I am fatisfied, and to this the facrificer anfwered, Eat and drink more *. It is difficult to imagine how a ftriking refemblance could be found between this Chinefe infant, and the cuftom of the Egyptians, who, at the end of their joyous feafts, introduced the figure of a dead perfon, and faid to their guefts, Drink and re. joice now, for fucb muft foon be your fate alfo. An an. cient poet has expreffed this maxim in a verfe too well known to require repetition. In China we find a funeral ceremony, a facrifice, and an interment: while the Egyptians, on the contrary, invited their friends to a great repaft for amufement only, as we learn from Herodotus and Plutarch. Neither of thofe

where pantomimes and farces are played during the fairs. Bread and public amufements, was the cry of the Roman people. Buffoon: eries and commerce are every thing to the Chinefe." Voyage round the World, vol. ii.

* Father du Halde mentions that cuftom in his Defcription of Cbina; and he was not aware, moft probably, that it would be ada puced as a proof of affinity with the Egyptians. 
two authors ever thought of infinuating that the feaft was celebrated in the prefence of the mummies, or the embalmed bodies of their anceftors. The dead bodies in Egypt were inmediately committed to the raults, unlefs when fome impediment took place either from the law, or on the part of the creditors; and a kind of infamy was always attached to thofe who were prevented from burying their parents. Befides, no connexion whatever can be difcerned be: tween a little ftatue of wood, reprefenting death, and Chinefe children in good health, who ate and drank in the name of the corple of their father or mother.

Thus all the contormities hitherto imagined in this matter are of the fame nature with thofe which have led Mr. Huet to believe that Mofes was Adonis, or Jacob Typhon, according to Mr. Fourmont; while Croefe fees nothing more clearly than that the perfonages in the Bible are the heroes of Homer, and thoufand circumftances in his opinion prove, that Ulyffes and the nymph Calypfo were Lot and his daughters.

What has been already faid concerning the religion of the Chinefe is fufficient to prove, that it differs in every point from that of the Egyptians, and the fame difimilarity is fo evident in their rites, that nothing but blindnefs and obftinacy can prevent its being perceived and confuted. No human body has ever been opened in China with the idea of converting it into a mummy; and all practices relative to the art of embalming are there entirely unknown. The dogmas of the two nations, concerning the future 
ftate of the foul, are equally irreconcilable; for the Chinefe, fo far from admitting the amentbes of the Egyptians, never heard of either purgatory or para. dife, in all their canonical books or kings. On that account fo many miffionaries and others have conftantly confidered them as difbelieving the immorta. lity of the foul, without reflecting that the offerings made to the dead contradict in the ftrongeft manner that opinion. But, in truth, the Chinefe can form no idea of any place of captivity for fouls; and they fuppofe them transformed into manitous, or kuei-cljin, and preferving to a certain degree the liberty of rambling *.

We find fome light thrown on this matter by a lentence pronounced in China againft two Jefuits who preached the dogmas of the Catholic religion, after it had been prohibited by an edict. Thefe bonzes, it proceeds, by inculcating a doctrine containing various puints on life, death, paradife, bell, and other falfehoods of that nature, have deceived many people. Conformably to the laws of the empire, these bonzes bave there. fore merited deatb. On this the grand criminal tribunal marked on the fentence, let them be frangled $t$.

* We do not fpeak here of the Clinefe people, who, following the religion of India, believe in the tranfmigration of foul, the fyftem moft generally adopted.

- The ancient doctrine of China, which fuppofes that fouls become manitous, or kuei-cbin, excludes entirely future pains and rewards: for thefe manitous are liable to be perfecuted by the bad genii, to whom the Chinefe give a name conveying nearly the fane idea as our word demons.

t Thiss feptefice is extracted from the Letires Edifianles.

Thợe 
Thofe, who paffed this fanguinary decree, had no experience in human affairs. The Marquis Beccaria obferves very juftly, in his Treatife on Faults and Penalties, that corporal and painful chaftifements fhould never be inflicted on fanatics, whofe crime proceeds from pride, and that paffion is gratified by fufferings. Infamy and ridicule, according to him, are the only means to be employed with fuch perfons; but to con. fine them is perhaps ftill more effectual.

Thefe, who pronounced the Chinefe fentence al. ready cited, conficlered as chimerical the places were fouls were fuppofed to be fhut up, either for punifhrnent or recompence. But they do not explain there in any manner their own opinions, which are neither the fublimeft nor the moft reafonable. Human fouls, ac. cording to them, are compofed of two fubftances; that by which they feel defcends to the earth at death; but the other is the fource of thought, and inhabits the fky or the middle regions of the air. Thofe two parts are fuppofed to be fo much affected by the piety and devotion of the facrifices to the dead, that they re-unite to partake of the offerings deftined for their ufe. The vifible affiftants however take care to have the beft portion, like the Laplanders, who devour the flefh of the victims, and afterwards prefent the bones to the gods.

This frange fyftem cannot be combined in any manner with the doctrine of paradife or hell, whence it is impoffible for fouls to efcape fo readily at the fight of a plate of rice, or flefh.meat, offered by the fuperftitious. We therefore perceive clearly the real 
meaning of the judgment pronounced againft the two miflionaries; and it is far from proving, as fome have hitherto fo obfinately maintained, that the Chinefe deny the immortality of the foul. Even their men of letters have frequently taken the greatelt pains to raife the fpirit of Confucius, whofe hiftory is very obfcure, and confidered by many learned men as nothing more than a collection of Chinefe fables, to which filly miffionaries have added their own. Father Martini relates ferioully, that one day it was told to this pretended philofopher, that the hunters had kill. ed a very uncommon animal, fomewhat refembling a lamb: on this he began to weep bitterly, exclaiming in his great grief, that he now forefaw the fhort duration of his doctrine. This lamb, as we perceive, mult have been a monfter produced in the brain of fome miffionary: but even the difciples of Confucius are faid to atteft that the ghof of a man named Tcheou-kong, who was then dead upwards of fix hundred years, appeared every night to their mafter. His mind feems befides to have been ftrongly infect. ed with numerous fuperftitions concerning forcery, or divination with rods, as we fee by his interpreta. tion of the fable of the $1 \cdot k i n g$, which bears more figns of authenticity than any other of his fuppofed productions.

It is neceffary here to ftate as clearly as poffible the expreflions of Mr. Vifdelou, becaufe they are of the utmoft importance, and feem altogether decifive. .

Confucius not only approved of forcery, but even taught in express terns bow to obtain predictions; and 
certaisaly. that practice bas proceeded entirely from bis füg. geftions in the Commentary on the T-king. Befides, Tfo. kieou-ning, a difciple of Confucius, whofe lefons be copied is bis Conmentaries on the Canonical Annals, bas inferted fo many examples of forcery that they are difgufing. Events there correspond fo exactly with predictions, that, if be is to be believed, they were really fo many miracles. All the Chinefe philofophers until this day ufe fuch fpells, by means of xibich they pretend to be capable of predicting every thing. In Jbort, they all adbere to the Book of Fortune*.

Mr. Vifdelou, who has furnithed us with thefe explications, was much better verfed in the Chinefe language and literature than Father Gaubil, who could not tranflate the Cbot-King, without the affift. ance of a Tartan copy. Vifdelou, on the contrary, received an imperial certificate, acknowledging him to be a very learned mant; and as he could read the Chinefe characters fluently, his teftimony is here very material. It was only from adopting the common cant of other writers, that he gave the name of philofophers to the literati in China, who, corrupted by the doctrine of Confucius, pretend to prophefy through rhabdomancy. The grofs fuperftitions of

- Notice of the $r$-king.

f. The imperial certificate, given to Mr. Vifdelou, was a piece of fatin containing thefe words: "We acknowledge that this man, who comes from Europe, is higher in the knowledge and fcience of our Chinefe characters than the clouds above our heads, and that he is more profund in euridition and penetration, than the abyffes over which we walk." This filly jargon fignified nothing elfe than that the bearer knew how to read and write the Chinefe language. 
thofe men betray fo much weaknefs and ignorance; that they cannot be excuied, even in the eyes of thofe who have carried their prepoffeffions to the greatefi length in favor of China. Mr. de Guignes, having quoted a paflare of Eufebius, concerning the inha: bitants of Sericum, adds, that the eulogy given of thofe people was exaggeration; in the fame manner; continues he, that we now beftow fo many extravagani encomiums on the Cbinefe. The lofs of time is not the only injury the reader has to fuffer from hiftorical fables, which are the fource of frequent errors, al: though fometimes not more confiftent than the dreams of thole who fleep in peace. Nothing how ever can difhearten me in citing facts, and pointing out confequences; becaufe that method alone can difpel all the falfe ideas, introduced into Europe con'cerning the Chinefe by fo many travellers, from Marc Paul down to Father Bouvet. The katter wrote a panegyric on the emperor $C a n-b i$ in the legendary ftyle, and compofed of nearly the fame fuff with the account given by Martini of Confucius, who repeated inceffantly; fays he, that a faint would appear in the $W_{e f t}$ *. If we are to believe fome hiftorians, who write like children, thofe-words produced very won: derful confequences, by ferving-to introduce the teligion of India into China. Thofe, however, who

* Martini, Hit. Sinenfis, lib.iv. Kia-yu is a kind of hiftory of Confucius, which even the literati of China confider as a mere romance. Yet we could wilh to have it tranflated, in order to fec how far it fuggefled thofe prodigies, which the miffionaries relate concerning Confucius. 
ON THE EGYRTIANS AND CHINESE.

examined better the fate of things, have perceived that a new worhip, more connected than that of the ancient favages of Scythia, became indifpenfably nec $\in$ frary in China. At all events thole miflionaries cannot be juftified, who dihonored their judgment and profeffion by maintaining, that Confucius prophefied the coming of the Mefliah, by the table of fortune and his magical rods *.

By fuppofing for an inftant, that the words attri. buted to Confucius were really his, the true meaning could only be traced to the converfation he is faid to have held with Lao-kingm, who travelled, it would apfear, in India and Thibet, where he muft have feen the grand lama. What we call at this day the fect of Lao-kium is nothing but the lamic worfhip fomewhat disfigured, or the fect of the immortals mentioned by feveral Greek authors. They tell us, that; in their time, among the Thracians and Scy. thians, monaltic orders, or religious congregations, were formed by people who never married, and in fact differed nothing from the bonzes of Lao-kium, generally called Tao-fer, or the inmortals.

Thus the pretented faint, believed by Confucius to be in the Wef, was fome celebrated fakir of India, or the grand lama himfelf. It is not probable that

* Father Couplet certainly intended to denote the Meffiah in his book on the Chinefe Sciences, where he makes Confucius ufe the feltowing words : Expeciandum sf quogd vokiat jufmodi vir fummè

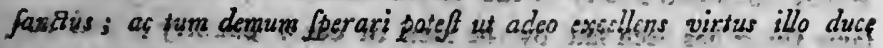
at magiftre in agum prodeat. Such abfurdities do not deferve to be confidered feriounly.

Vol: I: 
he fhould have alluded to any of thofe perfonages called in Europe the Scythian philofophers, fuch as Zamoixcs, Zeutos, Abaris, Diceneus, and Taxoras. An zcbarfis feems to have been later, if it be true that he was cotemporary with Solon, and even with Confucius, whofe chief maxims are certainly very fimilar to what Stanley, in his collection, attributes to Anacharfis *. The other philofophers of Scythia are little known; and we only underftand that they taught morality, and the cultivation of fome alimentary grains which grew wild in their country. Many plants of that kind are ftill found in a natural ftate between the fortieth and fifty-fecond degree of north latitude on our ancient continent. The origin of agriculture among the Scythians was enveloped in various fables; and thofe who inhabited near the Borifthenes contented themfelves with faying, that one day a golden plough fell from heaven into their country. This fiction is not difficult to be interpreted, and it difcovers more ingenuity than the great golden chain of the Grecian mythologifts.

According to fome difcoveries, the name of Confucius did not become very celebrated in China until about twelve hundred years after the reputed time of his birth. It -was in the eighth century of our era, that the emperor Hiven-tfong gave him the name

- Hift. Philor. part i. Anacharfis recommended moderation, which amounted nearly to the perfea medium of Confucius. siThe fame thing has been faid by the men of every country; and befides, the maxims generally attributed to Anacharfss, were perhaps compofed by fome other perfon. 
of: King of Letters; but he lot that vain and bombaftic title under the dynafty of Ming*. From this we might be led to believe that the emperor Hiventfong was a well-informed and equitable prince, who withed to honor merit and encourage virtue. But, on the contrary, he embrued his hands in the blood of his own children, and difcovered himfelf to be vile and defpicable in every thing. He was notorioufly addicted to the fuperftition of Tao-Se, and governed by eunuchs, who filled the empire with robbers, and occafioned the moft dreadful exceffes.

It is not improbable that about this time of fanatifm and trouble the religious worhip of Confucius became predominant in fome provinces, while in others it was entirely unknown. At leaft the Arabs, who then travelled into China, do not feem to have had much information concerning it ; and they tell us pofitively, that the Chinefe had not begun to apply themfelves to the fciences, and that they were much inferior to the Indians $f$. 'This is really true, even at the prefent moment, as far as it concerns aftronomy; for the Bramins in our days have determined with fome exactnefs the time when Venus was to pafs the difc of the fun; which is more than any of the literati of China were capable of doगases:

* Confucius was divefted of this title about the year 1384 ; and -fome hiftorians-believe that he, was not called King of Letters, unstit he received that name in the year.952, from the emperor TaiSou? : :

spat Ancient Accounts of India and China, publined by Renaudot. 
ing. Neither did that country, as the Arabs juftly obferved, begin to have fchools; and about the year one thoufand three hundred and eighty-four of our era, they werre firft built by the emperor Taefra, founder of the dynafty of Ming. That adventurer, a man of low birth, who had been cook or fervant in a convent of monks, then thief, and afterwards a leader of banditti, ended his career by becoming one of the greateft princes ever known in China. But the colleges which he erected foon fell into ruins, and the revenues attached to them were likewife diffipated, as we learn from a Chinefe author who wrote under the prefent dynafty of the Mandhui Tartars. After having fated feveral caufes of thàt fhameful decline, he adds, that the wife regulations of the emperor Taeflu, for eftablifing fchools in the country as well as in the towns, were very nuch neglected; and Father Trigault affures us, that not one remained when he vifited China $t$.

The novelty of the religious worfhip paid to Confucius is apparent from its ceremonies, as well as the form of the facred veffels employed therein, and the ornaments of the tabernacle and altar. All thefe things are copied after the ritual of the Indian pago-

+ Expedit. apud Sinas, lib. i. Nieuhof algemeene Befchryving van't Ryk Sina. The want of public fchools makes it neceffary to employ private mafters; and the Chinefe author we have cited obferves very juflly, that the poor cannot afford the expence. Ignorance is therefore perpetuated in fuch families; and the rich alone are in poffeffion of thore places which require a certain knowledge of the characters and canonical books. 
das; and the practices of the bonzes of Fo, except perhaps the immolation of animals. The latter feems to have been introduced by the men of letters them. relves, as well as the childilh cultom of proving the victims with warm wine.

It would be ufelefs to examine here whether or not the Jefuits in China approved of the folemn facrifices offered to Confucius during the equinoxes; but they. certainly condemned them highly in Europe. The reafon they affigned was their marked affinity with the fuperfitions of India, which could not be tolerated, fays Father le. Comte, without fcandal, and danger of fubverfion* ${ }^{*}$ Whence it. neceffarily follows, that, previous to the eftablifhment of the Indian religion in China, the worthip of Confucius was very far from being the fame as now; and no traces of it are found in any age anterior to our era. Some even pretend, that the emperor Scbi-cbuan-di committed to the flames all the works of this man, who wrote, or rather etched, on pieces of wood filed together on cords: Thofe thingles mult have loaded feveral carts, had they contained all the writings now publifhed in the name of Confucius. Yet notbing tends to prove that he is the author even of the $T_{\text {chun }-t f \text { cieou, or }}$ Spring and sutumn, the fhortent and moft interefting of all his fuppofed productions. It is placed among the number of the kings; but no perfon knows with

* 'The Jefuits condemned the folemn facrifices made to Conflcius; and they approved of otbers lefs folemn. Refponfum Epifcopi Beritenfis ad Cardinalem Marefcottum, \&c. 
any certainty by whom that chronicle was com. piled *.

We have already obferved, with regard to the burning of the books by Scbi-chuan-di, that the fact was not only doubted by fome critics, but even the motives affigned for it feem infufficient. The barbarian, it is faid, was mortified by the praifes beftowed on monarchs who were dead upwards of one thoufand years. It would be exactly the fame thing to reprefent the king of Spain as envious of the pa. negyrics invented by fome fools in Caftile for Tubal Cain; who having paffed the Straits of Gibraltar on his anvil, reigned gloriounly over all the countries beyond the Pyrenees; and his name is ftill inferted as the firt of the Spanifh kings.

Others pretend, that Schi-cbuan-di caufed all the writings of Confucius to be deftroyed, becaufe he thought they favored feudal government, which is the worlt of all, except defpotifm. But perhaps in the whole world no works can be found more calculated for arbitrary fway than thofe publifhed in his name. They require a blind fubmiflion to the caprices of the prince, without condemning paternal power degenerated into tyranny or political flavery, perfonal fervitude, polygamy, confinement of women, or the cuftom of felling children. Thus, fo far from having any juft notions of morality, he was ignorant of all the principles of natural right; or elfe thofe who

* Some of the Chinefe literati do not count this chronicle among the canonical books, but merely as little fragments of the ro-king. 
forged his fuppofed books, were fuch wretched compilers, that, as Thomafius obferves, it is impoffible to read fome paffages ferioully*. The many common-place maxims they contain required no extent of genius; for moral fentences of the fame kind have been common among all the nations of the ancient continent, if we except fome few hordes of men, who, little better than favages, conducted themfelves chiefly by inftinct. But the morality of the Chinefe is entirely fpeculative, and their difhonefty in commerce fo great, that no gold or filver money can be trufted in their hands, and they adulterate even that of copper.

When the difputes in Europe concerning the ceremonies of China, were conducted with that atrocious fury called theological hatred, which changes men into tygers, it was afferted that the literati in China were atheifts in theory, and idolaters in practice. Yet the mind of man, with all its extravagancies, cannot be fuppofed capable of reconciling fo great a contradiction. The men of letters in China do not certainly believe the foul of Confucius to be the Divinity. Thus, their days of fafting, their facrifices, and all the ridiculous practices they have borrowed from the bonzes of $F_{0}$, prove evidently. their fuperftition, but not their idolatry.

Real philofophers would endeavour to honor the memory of Confucius by rendering themfelves more yirtuous, and not by fhedding the blood of victims. :

+ Penféég fur les Livres nouveaux, à l'an 1689. 
The great Newton, who could not endure to fee the death of a chicken or a lamb, would have been very far from affiting at their facrifices in fpring and autumn. Superftition characterifes equally the lefs folemn ceremonies, which take place nearly twice in each lunary month, and inftead of having any connexion with philofophy, they are dedicated to the prediction of future events.

If the French nation, refolving to reverence in a very extraordinary manner the memory of Defartes, thould introduce the monkifh practices of the Minims and Carmelites, they would no longer be regarded as wife men, but as filly people, worthy of the greateft contempt. Yet the literati of China have undoubtedly copied their ceremonies from thofe of the monks, and like them they faft in preparing for their facrifices. Mr. Jackfon, after examining why the Chinefe have no myfteries or initiations, like the Egyptians, Greeks, and Romans, concludes that nothing of the kind wa's neceffary with them, becaure they never Qeified men*. He imagined that nothing more was revealed on thofe occafions, than that the gods of paganifm had been mortals : but that fuppofition being falfe, the reafon alleged by him vanifhes; and If capable of proving any thing, it would be exactly the contrary of what he intended.

By reading attentively the Panthén of Mr. Jablonki, whofe refearches have been carried as far as poffible, it will be feen that the Egyptians never ten-

- Charerolegical. Antiquirites, zit the atricte China. 
dered to any man, living or dead, fuch fufpicious honors as the Chinefe did to Confucius. Hence it follows, that in China myfteries were more neceffary than in any other place, to preferve the human mind from the abyfs into which it might be drawn by the appearances of public worhip. If we are to believe the mifionaries, fuch abufes have in reality been carried to the greatet length; and we know the famous decree publifhed by Cardinal de Tournon at Nankin*. But here we are not to reafon after the ideas either of mifionaries or cardinals; and it is fufficient to obferve, that, if not the flighteft trace of initiations has ever been known among the Chinefe, it is an additional proof that they never had any communication with the Egyptians, who, according to Warburton himfelf, were the inventors of thofe ceremonies.

Although Fo or Buidba hais preached, as is well known, a double doctrine, we do not find that the bonzes of China ever took advantage of it to eftablin myfteries. They follow almoft generally, at this day, the exterior or fymbolical worhip; and it is only among the fakirs of India, that fome fétator's are found of the internal doctrine, in which certain ig. rorant travellers and miffionaries - fancied they fat all the principles of Spinofa. But no fyltem was

* The third artiele of this đécree condemus sas detertable idolatry the worhip paid by the literati to Confueius. . But. weere the Chinefe to pronounce entirely from appearances on what pafítes

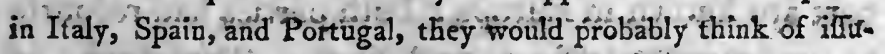

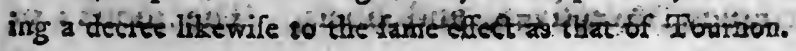


ever more contrary to atheifm than that of Budba; and were this fact not univerfally admitted at the prefent day, we might be tempted to demonftrate it molt evidently. That Indian who corrupted the ancient dogmas of his country, was an auftere fanatic: he overftrained every thing, and rendered virtue ridiculous. It was not only neceffary, according to him, to deftroy the paflions, but even the fenfes; and he ordered his difciples to confine their thoughts folely to the Divinity, keeping their bodies in continual repofe, and their minds in conftant meditation.

The vain pretext of attaining a ftate of tranquillity, entirely oppofite to the nature of man, and even of beafts, filled China at length with a multitude of monks. The greateft impoftors, and moft cunning of thefe intriguers, obtained fixed eftablifhments in the beft provinces, while the others wandered about begging or robbing the people. The abufe became fo general, that complaints were carried to the throne of the emperor, who was a prince born with the loweft fentiments, and whofe weaknefs approached to idiotifm. Inftead of relieving his fubjects by defroying the diforder in the bud, he declared himfelf publicly in favor of the bonzes and bonzeffes of $F_{0}$, who ever fince the beginning of the fourth century fuppofed themfelves capable of contending with the adherents of Lao-kium. - This fpirit of rivalihip was the fource of many crimes, of which only the fmallet. part are known in Europe : both parties had recourfe to intrigues, invectives, and libels. The monks of 
Fo are faid to have caufed more than five thoufand volumes to be written in their name, either to juttify their rules and doctrine, or in defending themfelves againft calumnies, and abufing others. They always reprefented to the government, that as the empire had no priefts, the people could not difpenfe with monks; and they held forth that hofpitality was confined to their pagodas, when that virtue became more neceffary from the wretched ftate of the inns. Travellers, they alleged, could gain admittance at every hour into their monafteries; and even ambaffadors had frequently lodged there; becaufe congquan, or public-houfes, were not erected in all the towns, or had fallen, as frequently happens, into ruin.

The inns are indeed beyond comparifon more paltry in China than even in Spain and Portugal *; but the bonzes had no right to remedy one great abufe by another, ftill more enormous. The Jefuits pretend, that no perfon can pafs a night with fafety in the bonzeries; and yet we find by their own accounts, that they frequently lodged there, without our ever having heard the number of thofe who were robbed or affaflinated.

- Some of thefe inns appear better furnibed than others; but they are all exceedingly wiretched. They coinfill of four earthen walls without plafler, which juftain a roof where the rafters are vijible. After all, it is fortunate if this covering be weather-proof. The chambers are fometimes full of boles; and defitute of even a common pavement. Du Halde's Defcription of China. Such are the beft hotels in China : the others, in the centre of the provinces, are too bad to admit of any comparifon. 
'The poffeffions, as well as the credit of the monks of Fo, were confiderablyaugmented by an edict of the em. peror Ven-ti, who declared himfelf their protector; but ftill more by the culpable conduct of the emperor Kao-tfou. Having efcaped from his palace, he was foon after found in an hermitage, or bonzery of the fecond rank, where he began by fhaving his head, and ended by embracing all the rules of Fo. This filly prince was afterwards brought back to court; but his folly remained incurable.

As the northern parts of China were then governed by particular princes, the monks found more diffs culty in fixing themfelves there than in the fouth, where the fertility of the foil being greater, and phyfical wants fewer, the people could give way to their more exalted enthufiafm, in providing them with food and clothing. All at once the refolution was taken throughout the northern provinces of deftroying the whol e of their convents, fome of which, like: that called rong-cben, or perpetual peace, contained. upwards of a thoufand perfons. In thort, all the bonzeries there were reduced to afhes about the year five hundred and fifty-feven of our era; but no meafures were taken to prevent them from being rebuilt; and they re-appeared foon after.

This ftorm in the north had not fubfided more than fixty-nine years, when another arofe in the very court of the emperor raoti, who, owing to the wretched ftate of population, could no longer recrait his armies. The bonzes of Lao-kium, who disected that prince, confidered the moment as very 
favorable for ruining the monks of $F_{0}$; and they advifed 2 ao ti to carry off from the convents one hundred thoufand men, and force them to marry in defpite of their yow of chaftity. That advice produced an edict on the twenty-fixth of May, in the year fix hundred and twenty-fix, which reduced almoft to nothing the number of pagodas and monafteries, called fon in China. But as the impofitions of the monks of Lao-kium had dictated that edict, the intrigues of the monks of $F_{0}$ occafioned its repeal forty-two days afterwards, to the fhame of the prince and his minifters.

The weak emperor Tao-ti was replaced on the throne by Tai-tfong, who, far from diminifhing the number of bonzes and bonzeffes, received into his ftates certain devout frangers, fuppoled by fome to have been Neftorians. Their eftablifhment in the province of Cben- $\sqrt{2}$ caufed for a tine the hatred and jealoufies of the monaftic orders in China to ceafe; and they united to exterminate thefe pretended Neftorians. Their pagodas were levelled to the ground, and their adherents cruelly perfecuted until the reign of the emperor Hiven tfong, who finding himfelf attacked in the centre of his dominions by robbers, and on the frontiers by the Tartars, not only pro. tected the different fects, but even favored the fol. lowers of Confucius.

The conduct of the Chinefe hitherto difcovers neither rule nor plan for delivering themfelves from the bonzes, who, inftead of being reformed, were attacked fuddenly like enemies, and afterwards ren ceived into favor Much of their property was 
taken away at certain times, and more reftored ta them at others. In this manner they fluctuated between extremes with an inconftancy only equalled, perhaps, by the facts we are about to relate.

As the police was then exceedingly neglected; a new order of Seng, or Itrange monks, found means to introduce themfelves into the empire. They are taken by fome for Lamas, and by others for Manicheans, who had formed themfelves into a congregation*; but, at all events, they were included in the profcription of the emperor Wou-tfong. When we know that he had placed his confidence in the monks of Lao-kium, it can no longer appear furprifing, that thofe avaricious fanatics fhould have taken advantage of that inftant of favor, to crufh their rivals; and exterminate them altogether.

Tchao-kouey, who was prelate, or chief, of the order of Lao-kium, promifed to procure the drink of immortality for the emperor, if he would iflue an-ediat againft the monks of Fo, or Che-kia The prince took the potion, and figned the decree; on the feventh of Auguit, in the year eight hundred and forty-five of our era. This occafioned the deftruction of four thoufand fix hundred principal monafteries, which. contained two hundred and eighty thoufand monks and nuns, whom the magiftrates reftored to the ftate, and fubjected to the poll-tax, from which they had withdrawn themfelves fraudulently, at the expence of the people. The number of monafteries of

* Father Pons fays, that India contains hermits, or monks, called Mouni; and it appears that this word has been confounded with Mani, which is fometimes ufed in Afia to denote the Manicheans. 
the fecond rank, condemned to the fame fate, aniounted to forty thoufand, poffeffing one hundred and fifty thoufand flaves, and about one million tcbing of freehold lands. All thefe were confifcated by the em. peror, and added to his domain, without examining how they had been acquired; for he concluded every thing found there muft be ufurped property *.

The order of $F_{0}$ became fo completely annihilated, that the fectaries of Lao-kium publinhed their triumph in canticles of joy to. Heaven for fuch remarkable favor. But the intriguers of the court, the women, and the eunuchs; prevailed in having the edict modified feven or eight days after it had been iffued. The emperor allowed four or five hundred monks of $F_{0}$ to remain in his dominions; but all the reft were dragged ignominioufly from their convents. Not a ruin of all thofe buildings was allowed to remain, and the clocks were converted into money, which was as fcarce as mifery was common. China then prefented only the thadow of an empire, and it deferved the title of the land of abufes. This reform, fo very defirable, continued to : be executed with fuccels, when the emperor Wou-tfong, under whom it had commenced, expired, moft probably by the drink of immortality he had the weaknefs to fwallow. Suen-tfong, who fucceeded to the throne, had ideas very different from thofe of his predeceffor; and he protected the monks of Fo againft

* If the number of monafteries then exifting in China be exagge. rated, it does not proceed from the tranflators. The Chinefe text fays four onan of foi, which makes forty thoufand convents of the fecond order. 
thofe of Lao-kium. Thus that order, which feemed to have been deftroyed, rofe again fuddenly, and became more infolent and pernicious to the ftate than ever. The prelate Tcbao-kouly, the author of the revolution, was hung or ftrangled without any formality; and the emperor condemned nine or ten more of the followers of Lao-kium to 3 fimilar deftiny.

Thus, in four hundred'and forty-feven, only two years after the refolution had been taken of relieving the people by difcharging a multitude of drones, an imperial edict was iffued for rebuilding all the convents and pagadas deftroyed in the preceding reign. The emperor then enjoined the tribunals to allow alf thofe of both fexes, who prefented themfelves for that purpofe, to embrace the order of $F$, or Che kia. Such has been the ftrange, whimfical, and inconceivable condust of the government of China. That country is now afflicted more than ever with the greatelt of all plagues; and no hope remains of any fortunate change, unlefs the men of letters apply themfelves to true fcience with more ardor and fuccefs. In fact, it is only by fpreading the light of philofophy, that the darknefs of fuperftition can be difpelled; and all attempts to deftroy the bonzes; while ignorance prevails, are contradictory. Thofe men, who, having efcaped amidlt fo many tempeits, furvive as it were even deftruction; would difappear gradually at the dawn of fcience. This is fo true, that when a prince of Japan founded fchools, and invited the learned into his dominions, the monks 
were feen deferting in whole troops from a country, where they began to ftarve, becaufe the people became enlightened. Yet the inftitution of monkifm in Japan is much more reafonable than that of the bonzes in China ; for the blind only are admiffible in the order of Fakis; and we have already obferved that cecity is very common there as well as among the Chinefe, who fuffer their blind to beg, tell fortunes, or live by proftitution.

The Tartar emperors indeed have not ceafed, during more than a century, to encourage the fciences; but their progrefs has hitherto been imperceptible. If the Chinefe could divent themfelves of that national vanity, to which they have no title, they would adopt without hefitating the writing and language of the Mandhuis. IThis muft be lefs difficult, as many of the literati know it already; and all Tartars, male or female; who intermarry with the Chinefe, are obliged by a rigorous law to teach it to their children*. That language is infinitely fuperior to the Chinefe jargon, in which nothing can be written with precifion on true fcience; becaufe it contains neither declenfions, conjugations, nor conjunctions for uniting the fentences: Thofe who ap-

- Some learned Europeans maintain, that no alphabetical character could ever be adapted to write a finging language like that $\sigma^{f}$ the Clinefe. Admitting this to be true, it is an additional reafon why they fhould adopt the Tartar language, which can be written by our letters. The pronunciation of the $\vec{R}$ is not an invincible obftacle, if the Chinefe would make the attempt. But the changes made in our days, by Kien-long, in the Tartar characters, are not merely ufelefs; they are pernicious. 
ply to ftudy, would certainly make more progrefs in one year, by means of the Tartar idiom, than could be $x$ ffected in fifteen by that of the Chinefe, joined to their characters. The whole of youth is confumed, and the memory encrvated, in acquiring fome knowledge of the letters or figns alone. - Thus the literati, who have learned as far as ten thoufand cha. racters, appear filly and fupid after the prime of life, and they are continually teazing the miffionaries of Europe for fome noftrum to fortify the memory. But the beft remedy they can ufe is, to abandon their manner of writing, and adopt that of the Tartars. Conring fuppofes that the hieroglyphics prevented the progrefs of the Egyptians in the fciences* ; but he reafoned without underftanding his fubject. It is not neceffary to go further back than the days of Moles, to prove that the Egyptians certainly made ufe of alphabetical characters in the fame manner that they are employed by us at the prefent day. The hieroglyphics were referved for particular matters, and their number muft have been very confined, becaule we fee the fame figures in almott all the monuments. Thus it was very improper to compare the Egyptians, who had an alphabet to the Chinefe, who neither ufed any thing of the kind, nor ever heard of the twenty-two letters, fuch as they have appeared on the bandages of the mummies. Mr. de Guignes could not have known thofe characters; and we muf, therefore, confider what he

Medic Herm. cap. xv. 
has written on that fubject as a mere exercife of the imagination. It is in fact as little founded as the voyage of the Chinele, who are made by him to arrive in America through Kamfchatka, as Bergerac went to the moon by the way of Quebec.

After this digreffion, it is proper to examine what the bonzes of China have advanced in favor of their being ufeful to the ftate. Their hofpitality, in the firt place, is the effect of an abufe which might eafily be remedied by improving the police, and erecting inns for the accommodation of travellers of every rank and condition. The cong-quan, or publichoufes, fell into ruin, it is faid, on the invafion of the Tartars. But we have little reafon to think, that thofe conquerors would have amufed themfelves with throwing down or plundering buildings almoft en. tirely deftitute of furniture. They were befides of no utility to common travellers, becaufe, in order to procure lodging there, it was neceffary to be provided with an order from the court. Concerning the want of priefts, or facrificers, who cannot be difpenfed with in the Indian religion, which has been embraced by all the people of China, that indeed is a great in. convenience. If the emperor, however, would only allot one fourth part of the lands poffeffed by the bonzeries for the maintenance of facrificets, the purpofe would bè much better anfwered, and thofe men might be employed in the public fchools, if any fhould be afterwards erected. Never was it known that the bonzes inftrueted youth in any of the pros vinces of the empire; and their ignorance is fuch, 
that they are really incapable of the tafk. Thus, in whatever light thofe men are confidered, they are un: worthy of the leaft indulgence.'

With regard to the monks of Lao-kinm, their pretenfions are faid to be founded on fome right, claimed by them, of affiting as muficians at the great facrifices offered at each equinox and folftice by the enperor, or the perfon deputed by him, in cafe of fick: nefs, minority, or abfence.

Admitting this to be true, the monks of Lao-kium have at leaft fome connexion with the ancient religion of China. Yet the fervices they render, by producing a deteftable mufic during the facrifices, could never compenfate for the evils they create by deceiving poor wretches, and even by poifoning them with the drink of immortality. By pretending to have the fecret of preparing this potion, they attract as much veneration as by their legends concerning Lao-kium, who de. fcended, as they allege, from the royal family of Tcheou. Thus, according to their genealogy, the imperial family of Tang muft have iffued from Laokium. Yet, in our opinion, he was an obfcure man; and hiftorians do not agree even on the precife time in which he lived *. The greater part make him, with much apparent probability, cotemporary with Confucius; and the prelates of his order affirm that, fince his death, their regular fucceffion has never once been interrupted. They therefore efteem themfelves

- Some hiforians pretend; that Lao-kium lived fill at the extinction of the dynafty of Tcheou, about 249 yeats before our era. 
as more noble than thofe reputed as belonging to the family of Confucius, who did not become illuftrious until a much later period. It appears to me, that this pretended family of Confucius is likewife fome kind of monaltic order or religious congregation; and this might have been known by making refearches at Cbio-fou, in the province of Cban-tong. That fpot, fo interefting, has been entirely neglected; at lealt we do not find any fatisfactory information concerning it. No judicious perfon will readily believe, that one family could have inhabited the fame burgh, during more than two thoufand years, amidit all the dreadful revolutions produced in China by civil wars, foreign invafions, irregular thocks of defpotifm; famine, revolts, and combinations of robbers. The latter alone, in a certain length of time, pillaged almoft the whole country; and perhaps not one town efcaped being taken by thofe ruffians, who fometimes were known to fhed more blood than foreign enemies. When Cantor fell into their hands, they flaughtered upwards of one hundred thoufand perfons; and their cruelties. at $\mathrm{Pe}$-kin have been already mentioned. It is therefore fcarcely credible, that the family of Confucius could have remained conftantly until now in the fmall town of Kiou-fou, unlefs we confider it as a monaftic order. In that cale, the fact changes entirely its nature, and does not require the fuppofition of any regular filial fuc. ceffion. This opinion feems to be confirmed by the title of Saint given by the Chinefe to Confucius ; and the religious worthip they render to him, conveys 
ideas very different from thofe attached by us to the word Pbilofopher, which has nothing fynonimous in their language. It is faid, likewife, that he introduced feveral changes in religion, and abolithed the cuftom of placing fmall ftatues in the tombs; but he would have acted more wifely by preventing his countrymen from filling the mouths of the dead with pearls, and burying them in a ruinous manner.

As the great facrifices of the Chinefe have long been fixed to the equinoxes and folftices, that circumftance is frequently cited as a proof of their progrefs in aftronomy ever fince the moft diftant ages. To this is added the firt chapter of the canonical book, called Chou-King, where, as Father Gaubil informs us, $\Upsilon_{a 0}$ is faid to have known with precifion the duration of the folar year, and the moft exact method of intercalation. Inftead, however, of employing that form of almanac, he forbade it among the people, and inftituted the lunar year. But the fact is, that the firft chapter of the Cloou-King is a compofition of a much later date, and cannot be admitted as proving any thing in favour of $r_{a 0}$. The canonical books of the Chinefe are too imperfect and confufed to admit of much faith; and the Cbou-King, faid to have been compiled by Confucius, who lived feventeen hundred years after $\Upsilon_{00}$, is at beft only a fragment, where forty.one chapters are wanting. Independently of all thefe confiderations, it is impoffible that the Chinefe, while they remained, by their own confeffion, in a ftate of barbarifm, could have been better acquainted with aftronomy than at this day, when they are 
obliged to employ Germans at Pe-kin to compore the almanacs of the empire. Can it be fuppofed, that, if any among themfelves were capable of performing. fuch calculations, they would invite ftrangers from a country three thoufand leagues diftant, to prevent a total confufion? It would be exactly a fimilar cafe, if the Academy of Sciences at Paris applied to the Talaquoins of Japan to foretel eclipfes in France.

The Chinefe year, we hould obferve, was always lunary, and never commenced towards the rifing of Sirius. Thus they differed as much from the Egyptians in their calendars, as in their religious inftitutions. If they were alike addicted to judicial aftrology, their error is common to all the nations of Afia and Africa, where the ancient worhip of Itars and planets neceffarily produced that fpecies of fuperftition. When the Arabs.became mafters of the tribunal of mathematics, they took care not to rilk their bread by abolifhing fuch practices; and Father Hallerftein himfelf is now under the necelfity of inferting various predictions in the $\tau_{a n g-\sqrt{10}}$, or almanac, compiled by him, as chief of the aftronomers. That body is principally compofed of Europeans; and, without their aid, no ban-lin or college of Pékin could be compared to the prefent Gia-meacel-afbar, or the academy of Cairo. Yet the arts and fciences in modern - Egypt have 'not preferved the thadow of their forner fplendor.

The diforders prevalent in the Chinefe calculations at the conqueft of the Mogul Tartars, prove fuffi. ciently that, long previous to that epoch, the grand 
facrifices could not be-performed exactly.as they were intended at the equinoxes and folftices: Neither of thofe periods were indicated in their calendar, which was held in fuch contempt throughout Afia, that the people inhabiting between Bengal and the province of Yun.nen refufed to adopt what they juftly termed a bundle of errors. When the Arabian aftro. noners, by order of Koublai Kan, had rectified thefe blunders, the pride of the Chinefe became infupportable, and they ordered the Indians to receive their calendars, or prepare for war. As no attention was paid to this menace, a Chinefe army of twenty thou. fand men marched againt the pretended rebels; but it received fuch a total defeat, that fcarcely a fingle perfon efcaped; and, ever fince, the project has been abandoned entirely. $y$ The intention was really to eftablifh a commerce with thofe books, although each of them fold for no more than eight kandarins. The Chinefe traffic with every thing; and, when unem. ployed in that manner, they are, like the Jews, out of their elęment.

Since the fecond correction of the Chinefe year, which took place under the Tartar emperors of the prefent dynafty, the folemn facrifices are performed punctually at each equinox and folftice with great parade; and the number of muficians employed there may amount to about five or fix hundred. Yet thefe, concerts, where the found of the drum always predo. minates, can give no idea of the ancient mufic of the Chinefe, which, as they fay, is entirely loft. Ac. çording to them; every thing has degenerated; and they 
they were much greater artifts in a ftate of barbarifn, under the Kan Fo-bi, than ever afterwards in civil life. Such ridiculous opinions do not deferve to be refuted. Their ancient inftruments of mufic, of which we find the different forms in the Cbou-King, were beyond comparifon more imperfect than thofe they einploy at this day, as every perfon mult perceive on infpecting the figures.

-Whenever the noife of the mufic is heard, the victims are butchered, and offered with much incenfe to the genius of the fky. 'No lefs folemnity is obferved in facrificing to the genius of the earth, whofe temple is confructed in a different manner. All thefe genii, according to the literati, are emanations of $T a i-k i$, or the Great Height; and in this we obferve nothing more than a rude deifm. Men plunged fo deeply as they are in an ignorance of nature cannot poffibly attain more fublime ideas, without the aid of philofophy and true fcience, which would foon deftroy the doctrine of fpirits or manitous. On the four fides of the altar are feen great ftones, reprefenting the genii of the mountains, wood, metal, air, and fire. It is chielly in honor of the latter, fays Mr. Orbeck, that the Chinele obferve the feaft of lanterns, that their towns; fo very: combuftible in their nature, may be preferved from the flames *.

Nothing can be more ridiculous than the idea, that this illumination had fome connexion with the feaft of lamps celebrated at Athens, and Sais, in honor of

- Reife nach Oftindien und China.

Minerva, 
Minerva. The Chinefe never even heard of that deity; and this is fo certain, that no perfon of real learning would attempt to maintain the contrary. If the moft knowing among the literati at Pe-kin were to fee a figure of Minerva, with the fymbols of the lamp and the fphinx, which the Greeks placed on her helmet; or with the fcarabee, according to the ideas of the Egyptians, they would underftand as little of that allegorical ftatue as of the hieroglyphics, or the obelifks.

It might have happened that the Chinefe celebrated the feaft of lanterns in February, on the fame day allotted by the Catholics of Europe for the feaft of luminaries; and, in that cafe, it would be ridiculous to infer, that one of thofe ufages had been copied from the other. The moft ftriking refemblances are fre'quently deceitful; and we have an inftance of this in the error of Bochard with regard to the fox-races in the circus at Rome. As fire-brands were tied to the tails of thofe animals, he imagined that the Romans intended in that manner to perpetuate the remembrance of an event fo memorable as that of the burning of fome corn-fields on the confines of Páleftine, contrary to the law of nations. But, in truth, the Romans were very-indifferent about what paffed in Paleftine; and the fox-race was much indebted to the imagination of Orid.

Nothing is more fabulous than what Father le. Conte, in his Memoirs on China, felates concerningthe origin of the feaft of lanterns. He pretends that the emperor Kie, having complained of the thortnefs. 
of human life, was advifed to light up his palace in fuch a manner that night could not be diftinguifhed from day. This infipid ftory, as we obferved before, mut have been extracted from another in Herodotus, relative to a king of Egypt, who having underftood, from the oracle of Buta in the Delta, that he had only fix years to live; caufed likewife his court to be illuminated, that he might enjoy the more light; as if a man, who had only fix years to live, could on that account difpenfe with fleep. But Herodotus, without examining matters fo clofely, contented himfelf with nating down all the abfurdities he could colleEt from the interpreters of Egypt.

Father Parrenin took care to write from Pe-kin to Mr. Mairan, that this origin of the feaft of lanterns was a mere fabie, publifhed in Europe by Father le Comte; who had, as we fee, profited greatly by read. ing Herodotus; and if the thing deferved the trouble, we could demonftrate here, that the Jefuits have in. ferted facts extracted from the Bible in the Hiftory of China. When the Chinefe authors are confulted on the pretended adventure of the prince or emperor Kie, we find nothing but childifh and difgutting prodigies. They affure us, that during his reign a ftar fell from heaven; that the fyftem or courfe of the planets was evidently deranged; the mountains fell down, and three funs appeared at once:towards the eaf. Yet no perfon could fee at the icourt of the prince, becaufe he had rendered all his apartments inacceffible to the rays of light. It is almoft fuperfluous to add, that hiftory, written in this manner, does not 
not deferve to be read. All that the Chinefe know really, concerning the emperor Kie, comprehends very little indeed; but with them prodigies are frequently fubftituted for hiftorical facts. They incerfantly praife Confucius for having fpoken of the fall of ftars, the rolling down of mountains, the fong of the matchlefs bird, the apparition of the unicorn, and the metamorphofis of infects, which they long confidered as miraculous.

'Thus, as we have feen, no connexion whatever fublifts between the feaft celebrated in honor of Minerva, and the great illumination of China, where all the fymbolical divinities of Egypt are unknown. It is not neceffary to confider here the difference of the terms Tien or Cbang-ti, ufed by the Chinefe to denote the genius of the fky, and the Egyptian words Pbtha and Cnuph, in which Eufebius perceives the Creator of the univerfe. The Jefuits acknowledge unanimoufly, that the Chinefe form no fuch ideas of their genii ; and Mr. Leibnitz conforms to that opinion*:

Confucius, it is faid, was afked to explain his fentiments of the Divinity; but having excufed himfelf for the time, he went home, and wrote, as Father Couplet fays, the following words in his Commentary on the $r_{\text {-king: }}$

The Great Height engendered two qualities : the perfect and the imperfect. : Thefe two qualities engendered

- Martini, among the reft, expreffes himfelf thus : De fummo ac primo rerum Auctore mirum apud omnes Sinas jlentiam : quippe in tam. copiofa lingua nec nomen quidam Deus babet. Hilt. Sin. lib. i. 
four images: thefe four inages produced the eight fingures of Fo-hi, that is to fay, all things.

Who at the prefent day would venture to affert; that this declaration contains the fmalleft particle of common fenfe? It anfwers no purpofe to object, that other ancient philofophers have fometimes written in 2 manner equally unreafonable. They at leaft never pretended to write treatifes on forcery, or rhabdo: mancy, fuch as that wherein Confucius is faid to have inferted the words we have quoted, relative to divination by rods; which, we may be allowed to repeat, difcovers no fymptoms of common fenfe.

If any thing could have plunged the literati into fatalifm, it muft have been the foolin - doctrine of Confucius on the power of chance; and certainly fome of them have hazarded very monftrous chimeras; on the revolution of the five Chinefe elements, which alternately produce a new imperial family or dynafty. When, for example, an imperial family is produced by the power of water, or the genius prefiding over that element, it cannot give more than twenty em. perors, whofe actions are all the effect of fate or neceffity: if they were free, fay they, we could not predict them by the table of chances, commented upon by the great Confucius.

Although Mr. Vifdelou attributes this doctrine to the men of letters in general, yet we mult fuppole that only the fillieft among them are capable of puljlifhing fuch abfurdities. Probably, indeed, they underftand nothing of the matter; for in China, as in the reft of the world, people frequently confufe their 
ideas in fuch a manner, that they can no longer ex: plain either what they credit or difbelieve. Thus, fpeaking of the religion of China, we have ftated only general opinions; becaufe it would be difficult to find two or three hundred of the literati poffefling precifely the fame fentiments, and a like number capable of remaining one day invariable in their principles; and as many more who form diftinct notions of what they pretend to believe. Thofe, who make the human foul double, which comes nearly to the fame thing with the bomo duplex of fome metaphyficians of Europe, may be counted among the number of thofe who do not underftand themfelves. Father Longobardi fays, in 'his famous treatife, that the literati of China declared to him openly their fentiments of atheifm. But they had perhaps fuddled themfelves, like Hobbes, whofe infidelity frequently difappeared with his intoxication.

The paffion of the Chinefe for forcery proves them to be fuperftitious, but not at all fatalifts. Befides the divination by rods, they practife another mode with a plant called chi. After having drawn out the fibres of the leaf, they throw them at random, and then examine how far their pofition agrees, with the $\Upsilon$-king. This method appears to me to have been practifed with very little variation by the foothfayers of Scythia when they twifted the leaves of the villow, erroneoufly called the lime-tree in the latin ver. fron of Herodotus. That author mult have had very particular information concerning the Afratic Scythians, for the truth of his details is confirmed daily : 
and it would be difficult to conceive the polfibility of his being fo well acquainted with the cuftoms of thole diftant nations, did we not obferve the fame accuracy in the geography of Ptolemy. He points out precilely fome parts of Sericum, or Igour, although thofe countries were the end of the world to the Greeks and Romans, who knew as little of the Chinefe as we do of the inhabitants of the South Pole. Herodotus had travelled into Colchis; and, when we reflect on the extraordinary route by which the merchants of that country found means to traffic with India, we may be able to account for his precifion.

It is generally believed, that the fectaries, fuppofed to be Neftorians, went in the feventh century to preach Chriftianity in. China, where they were firft protected, then perfecuted, and finally maffacred. They had the difciples of Lao-kium, the bonzes, and the emprefs, for declared enemies; and their preaching anfwered no other purpofe than to produce bloodfhed. Not one Chriftian remained in China at the conquelt of the Mogul Tartars, who favored indifcriminately all ftrangers, whofe induftry might be ufeful to the flate; without caring what was their religion, Konblis Kan even fixed fome Clriftian familiez at Pe-kir, which the patriarch of Bagdad on one fide, and the pope on the other, erceted into an archibifhopric. But the emperor eftablithed a tribunal, called crfoums: foufe, to fuperintend the two metropolitans. On the expulfion of the Mogul Tartars, the Ghriftians after fuffering another viofent perfecution, were :at length 
totally extirpated. The mof prudent fled to Tartary; fome embraced the religion of the bonzes, and the reft were maffacred. In the year one thoufand five hundred and ninety-two, when no trace of Chriftianity could be found in China, fome miffionaries began again to preach there; but the Neophytes, except a very fmall number, who held confiderable employments, were all of the vileft dregs of the people. As the wives of that clais of men went to church, the better fort of Chinefe were much fcandalized, and they confidered the miffionaries as corrupters: Sonie Jefuits fancied they could calm fuch fufpicions by having feparate chapels for the two fexes*: but this intended remedy only aggravated the offence.. The governor of Ham-theou was fo exafperated, on hearing that many women were fhut up in a church with two or three men, that, without waiting for orders from court, he caufed the chu:ch to be levelled to the very foundation. In their refpective departments, the governors act in a manner almoft defpotic; and the Chriftians have fometimes been frongly protected in certain provinces; while violently perfecuted in others. Polyganı, however, was always an infurmountable obftacle to the progrefs of their doctrines. The miffionaries, infifting pofitively on repudiation, would not allow their converts to preferve more than one wife : but they never attempted to abolifh perfonal bondage, although it is more contrary to the rights of nature than polygamy, which is almoft a neceflary.

- Gobien, Hiftory of China. 
confequence of flavery in warm countries. It was pretended, that the primitive Chriftians never required fuch facrifices ; and that different religious conmmunties in Europe poffeffed bond-men during many centuries. But this was a dreadful abufe, which cannot be alleged as a precedent; for what is contrary to natural right can never be admitted in morality. When a Chinefe had married feveral wives, in conformity to the laws of his country, he could not re. pudiate them, efpecially when mothers, without injuftice; but he was always at liberty to make his llaves free; and thus the conduct of the miffionaries was altogether contradictory. On the other hand, the government of China never knew what religion thould be tolerated or excluded. Admiffion was given there to Jews, Mahometans, Lamas, Parfis, Manis, Marrha; Si-lipan*, Yeli-Kaoven, Armenians, Bramins, Neltorians, Greek Chriftians, who had a church at Pe-kin, and to Catholics. The latter, however, fuffered more perfecution than all the reft together, and they were at laft totally exterminated. The emperor Can-bi alone iffued three contradictory edicts concerning them. He firft prohibited preaching, then gave permiffion, and afterwards enforced his firft decree, without ever knowing in what the Catholic religion confifted. It is a fact, that the miffionaries never dated to thow him either the Bible or the Evangelifts. We are affured, and with much ap.

* The religion of the Marrha and of the Si-lipan is not well known; but it is probably a miltake to fuppofe them to be Chriftians.

VOL.II. 
parent truth, that in one thoufand fix hundred and ninety-two, this prince knew nothing of the conquefts made by the Europeans in America, on the coaft of Africa, in the Molucca Iflands, and in fo many parts of Afia. Let us only reflect on fuch men as the Mandhui Tartars, who all at once fubdued China, without having any notion either of hiftory or geography; and then we cannot be furprifed, that the emperor Can-bi hould be totally ignorant of the conduct of the Chriftians in America. It was from his being previounly unacquainted with fuch matters, that the memorial, prefented at Pe-kin in one thoufand feven hundred and feventeen, made an indelible impreffion on the minds of the Tartars. It reprefented the Chriftians as a band of confpirators, who intended to render themfelves mafters in the enipire; as they had done in the New World. This project certainly was not real; but it feemed probable to the Tartars, who had not eighty thoufand effective men when they entered Pe-kin. They were indeed favored by the etrnuchs of the palace; but the taking of the capital was nothing, as long as they had not poffeffion of the fouthern provinces, which however were conqueted very rapidly. Not one inland town of China is capable of reffifting a regular fiege of three days; /and admiral Anfon declared, that a fingle thip of sfixty guns would be fufficient to fink a whole Chinefeffeget. The perfon, who fought to alarm the court of Peskin on account of the Neophytes and mifionaries, imuft therefore have been well acquainted with the weaknefs of his own country. It has, in fact, hitherto. efcaped 
efcaped the fury of our European robbers, merely from its great diftance; and even that barrier would vanifh on the difcovery of a north-welt paffage. The princes who fucceeded Can-bi, far from tolerating Chriftianity, did not ceafe, until the year one thoufand feven hundred and fixty-fix, to reftrain Europeans more and more, and to ufe greater precautions againft them. But, without intending any act of benevolence, they would have rendered the greateft fervice to Europe, by fhutting their ports entirely to the thips of the five nations allowied to traffic at Canton.

We terminate here this Section, after having de. monftrated that never two nations refembled each other lefs, in what concerns religion, than the Egyptians and Chinefe. The immolation of victims indeed was common to both; but the fame ufage has been found by modern travellers to fubfift in all the countries they have vifited, except India and Thibet, where the particular circumftance of the tranfmigration of fouls has counteracted the general rule. The learned have been at a lofs to know, how fo many nations of the ancient and new continents could have fallen alike into an extravagarice fo oppofite to all notions of common fenfe, as that of flaughtering animals in honor of God. Some fuppofe it muft have commenced with prifoners made in war: but the firft people evidently imagined, that nature contained certain genii, who came to tafte the blood, flefh, entrails, or fmoke of the facrifices. As all were originally hunters, and afterwards thepherds, it is more natural that they fhould have fought to regale the gods 
with flefh, than with fruits, which the manitous themfelves could find in the forefts. Thofe, who quitted the paftoral life to till the earth, began at length to offer the firt fruits of their fields; and then the immolation of victins fhould have ceafed. But it was continued, as we have faid, from the obftinacy with which the firft civilized nations adhered to the religious practices of favage life. This is the reafon why fo many cuftoms, invented by the Scythians, are found ftill in China, while thofe of the Ethiopians were as evidently continued in Egypt.

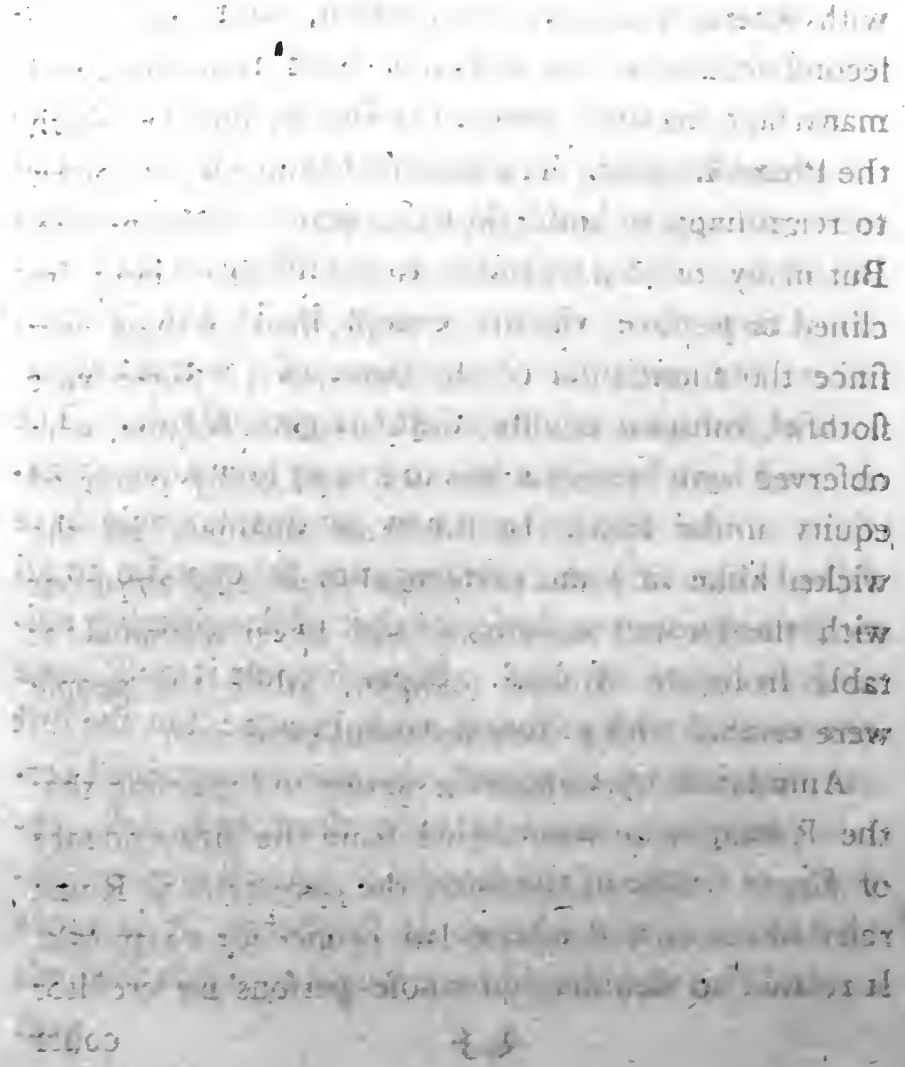




\section{S E C T. IX.}

GOVERNMENT OF EGYPT.

Omnia polt obitum fingit majora vetuftas.

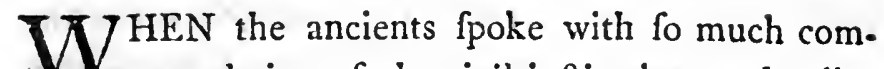
mendation of the civil infitutions and police of Egypt, they were under a conftant illufion. This was occafioned by the Greek authors, who confounded the laws, really obferved in that country, with others, which never exifted but in books. The fecond volume of the Hermetic Collection contained many fage maxims, relative to the manner in which the Pharaohs ought to conduct themfelves, in order to reign happily, and gain the applaufe of the people. But many of thole princes were far from being inclined to perform the duties prefcribed to the'm ever fince the foundation of the monarchy. Some were flothful, voluptuous, filly, and deteftable tyrants, who obferved only vain ceremonies, and really trampled equity under foot. In the fame manner, all the wicked kings of Judea performed their legal ablutions with the greatert exactnefs, and never deviated at table from the Mofaic regimen, while the people were crufhed under their unlawful exactions.

Ammianus Marcellinus is wrong in fuppofing that the Roman code was copied from the jurifprudence of Egypt. On the contrary, the decemvirs at Rome rejected the only Egyptian law proper for a republic. It related to debtors, on whofe perfons no crenitor 
could exercife the fmalleft violence; and this regu: lation was as wife and moderate as that of the de. cemvirs was barbarous. In fhort, the twelve tables did not contain the flighteft trace of Egyptian jurif. prudence, of which even Solon had little knowledge when he reformed the town of Athens, and abolifhed fome of the decrees of Draco ; for this took place previous to his journey to Saịs, where he feems to have traded.

Some of the Egyptian laws are fa fimple and clear, that they do not require to be analyzed. The contrary, however, was found in the regulation concerning thieves, which Diodorus the hiforian, and the lawyer Arifton, by contradicting each other, rendered fo complicated, that no philofopher could conceive either its meaning or object. According to Diodorus, the thieves of Egypt were obliged to infert their names in a regifter; and when any thing ftolen was claimed, they reftored only three-fourths of the value, becaufe the legiflator allowed them to referve a portion, either to recompenfe their addrefs, or to punith the negligence of thofe who fuffered their property to be ftolen. Diodorus, however, thould have perceived that many particular cafes could not be decided by this pretended law, but muft ne: ceffarily have required another, concerning which he is fllent.

I remember baving read, fays Aulus Gellius, in * work of the laroyer Arifon, that among the Egyptians, who were remarkable for their fagacity in fuidying nature, and great penetration in inventing the arts, every 
jpecies of theft was allowed by law, and practifed with impunity *.

By reflecting on thefe two whimfical inftitutions, it is eafy to perceive that they could not fubfift in the fame fociety, but might well belong to different nations. The authors, who have fpoken concerning them, were evidently ill informed, becaufe they are at variance with each other and with themfelves. What has been taken for an Egyption law is in reality an agreement made with the Arabs, who could not be prevented from ftealing and robbing. It therefore became cuftomary to redeem fuch effects as had fallen into their hands, as we find practifed frequently at the prefent day. The Bedouins reftore for the hundredth part of their value, the jewels they acquire in plundering a caravan; and they would be content to have always the fourth part in money, for the whole amount of the wares they capture, under the vain pretext, that the deferts of Arabia Petrea are their dominions. We find a modern traveller endeavouring to juftify this plea, as if it was not known, that the Bedouins commit fuch depredations very far from their wilderneffes, on territories, of which they were snever really poffeffed, and where of courfe it is unjuft in them to exact tribute from paffengers.

$\rightarrow$ Under the fhepherd kings the Arabs fpread themfelves in troops over all Egypt, and it became abfo-

* Id etiam memini legere me in libro Arifonis jureconfulti haudqququam indoci viri, apud veteres Agyptios, quod genus. hominum confat \&5 in artibus reperiendis folertes extitiffe, $\mathfrak{F}^{\circ}$ in cognitione rerum indagandá fagaces, furta omnia fuilfe licita É impunita. Noct. Att. lib. xi.

$$
\text { Q } 4
$$


lutcly neceffary to bave fome fixed compact with them, relative to the fpoils they might colleet, by fteallh or plunder. We have realon to believe, that pilfered goods were likewife bought back from the Jews; for it would be very furprifing, that fuch men as they, fhould have ftolen only once in Egypt, efpecially when protected by the ufurpers. Thofe tyrants favored thepherds and oppreffed hufbandmen, in order to counteract, as much as poflible, all the inftitutions of the vanquinied nation.

It is now eafy to form fome idea of what was meant by Diodorus Siculus. The names of the thieves were not regiftered, but application was made to the emir, or fcbcic of the Arabs, who knew his fubjects, and made them reftore what they had taken, on receiving the ftipulated compenfation We do not know how far the fame conduct was ob. ferved under the government of the Perfians, when a whole republic of banditti was eftablifhed in the Delta? Something of the kind, however, muit be adopted in every country, where robbers become too powerful to be either expelled or deftroyed. The' marfhes they poffefled near the Heracleotic mouth of the Nile were impaffable; and neither the Perfians nor Greeks could ever rid themfelves of thofe ene: mies; for their fmall veffels ferved them for houfes;

- If the fpirit of the Egyptian law had been what Diodorus fancied it to be, other regulations would have been neceffary for thofe who had ftolen without having infcribed their names, of who, although their names had been infcribed, did not reftore exactly what they had ftolen. 
and, on the flighteft alarm, they concealed them. felves at a great diftance among the reeds.

The extreme rigor of the laws in Egypt towards thofe who fubfifted by difhoneft means, proves how iittle they were intended to tolerate theft among the native inhabitants, who were neither Arabs nor Jews. Common fenfe has taught mankind, that, in a wellregulated fociety, no robult fubjects thould ever be permitted to beg; and Plato dreaded fuch people fo much in a republic, that he employs three different magiftrates for driving them firft from the markets, then from the towns, and afterwards, from the territory*. If that philofopher were now to reappear, and witnefs how many, in the different monaftic orders, live entirely on alms, he muft fuppofe that the human underftanding had fuffered a confiderable decline:

The Greek authors pretend, that Egypt had five or fix different legillators; and as fuch they confider Amafis, who preceded only a few years the fall of the monarchy. It appears, however, that all the general laws were much more ancient than the Greeks believed; and what they affert muft have proceeded entirely from their being very rigoroufly obferved under certain princes, whofe names are not exactly known. Pharaoh Bocchoris, faid by Diodorus to have been a very celebrated lawgiver, was not even known to Herodotus. Thus it becomes impoffible to place the laws of Egypt in any chronological arrangement;

วนey

- De Legibus, dial. xi. 
which, however neglected by Nicolai and Cafal, is very important, in order to trace the progrefs of legillation *.

Sabaccon, for example, is faid to have abolifhed in every cafe the punifhment of death; becaufe he pre. ferred condemning prifoners to work for the public. By thefe means, their fufferings were longer, but lefs fevere; and aithough not fo friking, they became more ufeful. Yet long afterwards, in the reign of Amajhs, we find death inflicted on thofe, who, averfe to work, and deftitute of fortune, fubfifted by that fpecies of induftry which is common to rogues and beggars. By fup; pofing all this to be fact, the jurifprudence of Egypt would appear to have been aftonifhingly variable: But in fact Sabaccon never had any pretenfions either to humanity or generofity. According to all hiftorians he was a ufurper; and if he really did not caufe Pharaoh Bocchoris to be committed to the flames, at leaft Nekos, the father of PSammetichus, was flain by his orders; and Pfammetichus would have fhared a fimilar fate had he not fled to Syria. 1 Sa baccon was, therefore, far from being the mildeft man of his age; and Strabo informs us that, inftead of condemning the culpable to works of public utility, he cut their nofes, and banifhed them from Egypt. Thus it is fuppofed to have been during his reign, that an eftablifhment was formed, called $\mathrm{Rhi}$ -

* Nicolai has written a treatife, with the title of, De Afgyptiorum Synedris - ${ }^{\circ}$ Legibus infignioribus. But it is neceffarily very confined, becaufe the author never underftood the fpirit of any law. His work is, therefore, lefs read than even that of Cafal, which contains at leaft fome fingular monuments. se

noculure, 
nocolure, or men without nofes; but this muft be confidered as fabulous. The word rbinocolure feems to have referred to an opening in the coaft, as appears in the map, where a promontory moft probably had funk down. In geography, the Arabs term raaf, or nofe, what we call cape after the Italians.

Thofe who lawifh encomiums on a princefs, becaufe the never caufed any perfon to fuffer death, although a prodigious number have been mutilated in her reign, may likewife, perhaps, praife Sabaccon, who cannot be faid to have done any other laudable action than that of abdicating the crown, and returning to Ethiopia, whence he came. Yet he was not the inventor of mutilation. It had been long prefcribed by the laws of the country for different mifdemeanors, and in this fome have pretended to difcover a remarkable conformity between the Egyptians and Chinefe. The amputation of the leg at the knee, a punifhment inflicted anciently in China, was never practifed among the Egyptians, who cut off other members, fuch as the tongue, hands, nofe; and, according to fome authors, the very genitals. It would be fuperfluous to repeat here what we have already faid, to prove that this could never have been the origin of the eunuchs of the palace, who fuffered mutilation in childhood, before they were capable of deferving fuch dreadful chaftifements.

Several nations of Europe, Africa, and Afia, have. had recourfe to various kinds of mutilation for certain crimes, which, according to their manner of thinking, did not deferve capital punifhment. Thus 
no particular refemblance can be admitted in this. point between the Egyptians and the Chinefe. The: latter, ever fince the origin of their empire, have permitted malefactors, in certain cafes, to commute their penalties for money. This firtt abufe introduced another in China, where poverty; or avarice, induces wretches to fupport floggings for thofe culprits who have money to pay for fubftitutes. The judge wifhes to exhibit a punifhment, and provided he finds any body to endure it, it is indifferent in his eyes. what perfon prefents himfelf for the purpofe. In Egypt nobody was allowed to purchafe with money a difcharge from corporal chaftifements decreed by: the law, and much lefs could any miferable wretches be placed under the hands of the executioner, inftead of the real culprits. Thus the Chinefe are, perhaps, the only people in the world, who buy and fell pu. nithments; and among them, as Mr. Salmon jultly. obferves, the firft notions of juftice are perverted, while all its formalities are rigidly obferved *

When fo many pecuniary fines were inflicted in the time of the lower empire, nothing more was ne. ceffary to characterize a bad government. The commutations for money, fo frequent in the codes of barbarians, prōe equally a mont defective jurifprudence. The Egyptians confined pecuniary fines to one fingle cafe, which wwas that of having inconfi:

* Prefent State of China, vol. i. Father le Comte fays, that near all the tribunals people are found who hire themfelves to receive chaftifement in the place of criminals. The judge muft certainly firft of all be corrupted. 
derately deftroyed any of the facred animals pro: tected by the law But it was ahways a capital offence to kill the ibis and the vulture. This latter is privileged alfo by the Englin; and it was of more utility in ancient Egypt than all the other birds and quadrupedes together. Had not the Thracians and the Greeks inflicted fimilar punifhments on thofe who took away the life of a ftork or an ox, the conduct of the Egyptianswould be unexampled. Yet no precedent could render it eritirely excufable. When any practice, very trifling in appearance, may be found derogatory to the public good, the legiflature has a thoufand means of remedying it, without having recourfe to torture. The Tufcan law, which inflicted arbitrary penalties on thofe who deftroyed their own bees by means of fulphur, was altogether ineffectual; and experience proves that fuch meafures never abolifhed a pernicious cuftom in any country.

- It is our intention here to fpeak only of the abufe which each perfon may make of public property, or even of what he himfelf poffeffes. We do not preterid to develope the atrocious game-laws, ftill fub-1s fifting in fo many places of Europe, where the killing of a roe-buck is fufficient to occafion the death of a man, and the infamy of a family. This barbarity originated from a race of men, - who anciently lived chiefly by the chafe, and whofe jurifprudence thould have been reformed, when they began to cultivate the ground.

The Egyptians had very fevere laws againft unfair dealing. They imagined in their purgatory, or amenthis, 
amenthis, an avenging genius for each fpecies of crime committed in the world*; and yet they were accufed of fraudulent practices in commerce. This however was imputed to them by the Greeks alone, who were a thoufand times more notorious for fuch vices, and whole bad faith will never ceafe to be proverbial among mankind. Egypt at one time, fays Strabo, perfifted in not opening its ports to the thips of Greece and Thrace; and it was then, continues he, that the Greeks filled Europe with calumnies againf the government of the Pharaohs, who, content with the productions of their own country; would no longer either give or receive. But Plato, who apparently had fome traffic in Egypt, begins by thowing that a nation fould cultivate arithmetical knowledge; and then, after fome common-place remarks, he infinuates Nily, that the Phenicians and Egyptians had made an ill ufe of the knowledge they had acquired in calculating and meafuring. Independently of this fubtlety, it has been obferved, that feveral nations of the fouth of Afia and Africa have always had an ex* treme inclination for ufury; equivocal contracts, mo: nopolies, and that fpecies of roguery which cha. racterizes the Jews in Europe. They in fact have given a great extenfion to the precepts of Deutero. nomy, which are more conformable to the ancient Nomandic jurifprudence than to that of Egypt. Moles was forced to refpect certain ufages already obferved among the Hebrews, previous to their being

- This might have occafioned the great diverfity of torments, which the Greeks and Romans fuppofed to be employed in their hell? 
reduced to a ftate of bondage." They were very fimilar to thofe eftablifhed among the Arabs, who have always been famous for their defective laws, and the fingularity of their crimes, fome of which, like fcopelifin, are fufficient to render a whole province defert *.

Many regulations were invented in Egypt to reprefs ufury, and prevent the violent meafures of moneylenders. The greatnefs of the evil is evident from the very remedy. . Among people who have much internal traffic, and fcarcely any with ftrangers, the merchants can only have fmall profit on their wares; and, therefore, they endeavour to gain largely on money. This produces ufury, and the evil increafes greatly, when bullion is ufed inftead of coin. We fhall find this to have been the cafe with the Egyptians, who anciently had only an interior commerce. They had not a fingle fhip at fea, while the Nile was co. vered with a multitude of boats, fome of which were made of baked earth. The fcarciry of wood there was always extreme, but not more. fo than the degree of induftry it occafioned $t$.

We are ignorant of the revolutions fuftained by commerce at different times in Egypt; but agricul.

- Scopelifm confitted in placing fome ftones in the middle of a field, to notify that the firft perfon who attempted to till it would be affaffinated. This crime is faid to have been peculiar to the Arabs; and it is the confegurence of their cefeetive civil laws refpecting murder, and the avengers of blood.

+ Thefe barks were the fmalleft kind of phafeli, called barri by the Egyptians; they went with fails and oars.

Parvula facilibus folitum dare vela phafelis,

Et brevibus pied remis incumbere tefta. Juvenal. 
ture appears to have been at all periods very flourith. ing. The foil required fcarcely any other expence than what was neceffary for feed; and fome grains, fuch as the doura, or millet, like the orintbis in Ethiopia, multiply there mof abundantly. Tillage was no-where attended with fewer difficulties; and little labor was neceffary in conveying moifture to the plantations with machines refembling chainpumps, which Diodorus feems to have confounded with the fcrew of Archimedes; who went, fays he, to teach that difcovery to the Egyptians. The fields, however, were well watered there, long before the days of Archimedes, whofe fcrew-punp is at this day totally unknown from Cairo to the Cataract of the Nile. Thus we perceive how eafy it was for the hubandmen of Egypt to repair their loffes, after having fuffered under tyrants, whofe hatred to the laws extended afterwards to the inhabitants. In our climates, on the contrary, agriculture is attended with much greater expence in men, cattle, and in. ftruments. When the farmers are half ruined by. impoits, they can never recover: themfelves by the crops; for it is demonftrated, that the lands always bear lefs in proportion as the property of the cultivator increafes. Reiterated labor and manure re. quire confiderable expenditure; but articles of that nature, fo important with us, are fcarcely counted for any thing in Egypt. This explains clearly why that country has fupported better than any other the deftructive government of the Turks; and for the fame reafon it might be rendered flourifhing in a century, 
ON THE EGYPTIANS AND CMINECE.

while more than three hundred years would be re- ${ }^{3}$ qsifite to produce the fame effect on Greece.

Although our notions concerning the ancient divifion of lands in Egypt are very confined, yet we know with certainty, that the military portions, lome of which confinted of twelve arouræ, paffed from la thers to fons, and not to daughters It follows, therefore, that the Greeks fpoke at random, when they pretended that, according to the jurifprudence of Egypt, daughters alone were obliged in every cafe tormaintain their parents, when old and infirm. But the obligation in fact extended only to affording thầt attendance, which was out of the power of their brothers, who, in the military and facerdotal families, were frequently long abfent. The foldiers were to do duty round the palace, every fecond year in rotation: the priefts were liable to be fent to Thebes to adminifter juftice, or to difcharge the functions of their miniftry; and then it was impoffible for them to pay particular attention to what paffed in the bofom of their families. It is not neceffary to repeat here what has been already faid of the condition of the: women in Egypt, nor the laws relative to polygamy, and the degrees of affinity which prevented marriage. We have clearly proved that the union of brother and fifter never took place there, until after the death of Alexander. All the authors who fpeak of that circumftance, fuch as Diodorus, Phito, Seneca, and Paufanias, are very modern in comparifon with the ancient Egyptians. 'Philo, however, is the only one who pretends that fuch marriages 
could be contracted even between a brother and his twin fifter*. We find, therefore, that this Jew imagined twins to be more clofely related than bro. thers and fifters born fuscefively. But the idea was altogether chimerical, and it would have been abfurd to make this exception, when all the Greeks of Alexandria were permitted to intermarry in the firft degree of the collateral lines. Twins have nothing to diftinguifh them from other children born of the fame father and mother, except that one of them is fometimes weakly; and yet this does not happen fo conftantly that it can be confidered as a rule of Nature. Yet if degeneration refults from inceftuous connexion, the effect muft be moft obvious on the offspring of a brother and fifter who are twins, although fuch experiments, when rade with brutes, have feldom produced any remarkable ef, fects.

Ancient authors would never have lavifhed fo many praifes on the legiflation of Egypt, had they been fenfible of the imperfections of their own. We allude here to perfonal flavery, which requires neceffarily fo many bad laws, that even the good are corrupted; for one great injuftice requires to be fupported by many others. It fhould be eftablifhed as

- De Spec. Leg. 6. 7,-Selden' believed that marriage be: tween brother and fifter was firft known in Egypt under the Perfians: but this is an error. The inceft of Cambyfes did not con. cern the Egyptians; and Seneca gives us diftinctly to underfand, that no perfon married his fifter, except in Alexandria. 
ON THE EGYPTIANS AND CHINESE.

an eternal truth and an immutable principle, that lavery is contrary to the law of Nature. Thus we may form an opinion of thofe legiflators, who ufed their authority and fanction to confirm, inftead of abolining, the abufe. No Egyptian had the power of taking away the life of his flave; and, by drawing a few confequences from this law, the eyes of thofe, who had fallen into fuch ftrange contradictions, fhould have been opened.

As liberty and life are really infeparable, the mafter always preferved the power of death while he appeared to be reftrained by the law. Few men in any age have been guilty of murdering their flaves, but thofe who caufed them to perifh flowly by hard labour were always very numerous. Thus we find that the law can only prevent a mafter from killing his flaves in one manner, while he has the choice of: a thoufand others; and in this confifts the contradiction.

Every:thing relative to freedom by birth among. the Egyptians was entirely oppofite to the inftitutions of the Romans, who adopted the abominable maxim, that children fhould follow the condition of their mothers: but in' all countries where polygamy is eftablifhed, it becomes indifpenfable that they fhould receive their rank from their father. No nation had ever more imperfect ideas concerning fervitude than the Romans. By the Claudian fenatus-confultum; we find a woman was liable to lofe her liberty (a pu. nifhment equal to death), when convicted of any illi. cit connexion with a llave. 
The fituations of thofe reduced to flavery in Egypt were anciently very different; for fome, we perceive diftinctly, had employments in the houfes, whilft others, appointed to till the fields, might be compared to our ferfs. As the greater part confifted of ftrangers, either purchafed or made captivcs, it was neceffary to kecp them apart, as long as they perfifted in their own religion. If admitted as houfehold fervants, they would have rendered every thing impure. This inflitution was, in its nature, fo very defective, that it required many bad laws to prevent revolts among fuch people, who could the more eafily form confpiracies as they were not under the eye of their mafter. It is probable that this occafioned fo nany extraordinary regulations to prevent murder; and we fee, by the cafe of Mofes, that they were not inftituted without reafon, although unexampled among the reft of mankind. In other countries, not to aflift a perfon againft affaflins is confidered as cowardice; but in Egypt it was a capital crime*. The law for that ob. ject; however, could fo cafily be eluded, that it muft have been looked upon as non-extant. Nothing was eafier than to allege numberlefs pretexts, to prove the impoffibility of fuccouring an unfortunate man, already in the hands of robbers. The legiflators, fenfible of the greateft part of thefe inconveniencies, propofed that the ferfon, at leaft, who did not de-

- Heliodorus feems to infinuate, that the fame law was found among the Ethiopians, and that it concerned even the children who were found, when expofed to perifh. 
nounce the aggreffors, fhould remain fome time in prifon, and receive a certain number of ftripes. But this law appears to have been annulled under the Ptolemies, when they entrufted the compofition of their code to Demetrius of Phaleris, who, as every perfon knows, had to labor for mon?ters.

It is generally confidered as a very whimfical circumftance, that the Egyptians fhould have had particular phyficians for different diforders, and even for the tooth-ach, to which they were fubject from chewing green fugar-canes; while the whole country did not contain one barrifter, although the pleadings were delivered in writing, according to the Greeks. In that cale, however, the priefts, who were 1 ound in all the towns, muft have drawn up the petitions and replies for thofe who could not read and write; but, in that point, the Egyptians in general feem not to have been deficient*. When the bad cultom of citing a heap of authors in juridical cafes is not adopted, and no captious reafonings are iniroduced; fuch papers can be difcuffed very promptly, and the Egyptians were never allowed to prefent more than four in the courle of one procefs. The judges; on their fide, confulted only ten volumes, and of thefe they com-

- According to the Egyptian laws, it was a great advantage to be able to read and writt; and even artifans gave this part of education to their children. The Judaic laws fuppofed alfo the frequent ufe of writing, as well for the gencalngies of the tribes as for contracts, bills of divorce, \&c. But the Jews neglected education greatly; and, in fome of the fmall towns, the fchoterim were the only people who sould read or write. 
mitted the greater part to memory *. Extraordinary cafes, which had no place in this code, were decided by a plurality of voices; and it appears, by the monument now extant in Thebais, that the number of judges was uneven. Thus the prefident did not turn the image of Truth to either fide, unlefs when the votes were equally divided. It would have been abfurd to decide in favor of thofe who had not obtained this equality, becaufe the arbitrary procedure, which was chiefly intended to be avoided, would then have been admitted. The plurality of fuffrages attracted always to their fide the emblem of Truth; and in that manner the procefs was terminated. No baftinadoes were ever given there to the pleaders. But the Chinefe fmother more law-fuits than they decide judicially; becaufe their government is defpotic, and that of the Eryptians was monarchic, as may be de? monftrated beyond contradiction.

It appears alfo, that, among the Egyptians, fome points were referred to oath; and not one word in their whole hiltory gives reafon to fuppofe that they ever employed torture. Under the dominion of the Greeks and Romans, experience proved that fuch means were ineffectual to obtain a confeffion from people, whofe obftinacy was exceffive. Thus an inftitution, which is abouninable in any country, would have been ufelefs in Egypt. Men of melancholy and gloomy

* Diodorus fpeaks only of eight volumes to which the judges applied; but here two volumes are fpoken of, which the prophets had to ftudy: 
confitutions, when expofed to a violent degree of pain, foon lofe all fenfibility : they fuffer lefs in proportion as the convulfion augments; and it was perhaps from phyfical caufes, that the Egyptians rejected the torments of hell, and believed only in purgatory. As, in certain cafes, folemn depofitions were admitted as proofs of facts, it became neceffary to place perjury in the number of capital crimes. Murder belonged always to the fame clafs, except when a father killed his own child; and then his punifhment confifted in holding publicly the dead body in his arms during three days : but the parricide had to fuffer the molt dreadful execution ever exhibited in that country*. This likewife has been fuppofed, without reafon, to difcover fome connexion with what is practifed by the Chinefe. The greater part of ancient nations entertained fimilar fentiments; and we have to lament that fome fhould have been fo barbarous and unjuft as to chaftife imaginary crimes, fuch as herefy and forcery, by more cruel punifhments than thofe inflicted on the depraved wretch who plunged a dagger into the heart of a parent. On the other hand, the Egyptians were certainly to blame for not preferving fome proportion in the manner of teftifying the abhorrence of the murder of a father and of a fon. When Nature has eftablithed an evident telation, it fhould always be

- This punifhment conffited in piercing the body of the criminal with reeds, and burning him in thorns. It has no refemblance whatever to the method of cutting a perfon into a thoufand pieces, practifed in China; where it is fuppoled to be a more modern invention. 
refpected by the legiflator. TVe muft however acknowledge, that the notions of the Egyptians, with regard to paternal authority, were lefs defective than thofe of the Greeks and Romans. But the Chinefe appear to have always had the fhocking maxim, that children thould not be confidered as human beings, until they had received their mothers' milk. This opinion, according to a learned lawyer, prevailed likewife among the ancient Romans*; and it appears no difficult matter to affign the caufe. Infanticide could be committed only by the father, according to the decree of Romulus, and then with the confent of the mother. From this proceeded the barbarous diftinction between children who had fucked, and thofe never admitted to the brealt. Wher the mother once began to nurfe her child, the was confidered as intending to preferve it; and then infanticide could no longer be allowed even with the confent of both parties. Thofe, who poffeffed fuch bad morals, muft necefrarily have had worfe phyfics; and the prejudice was thus eftablifhed, that children began to be human beings only when they received the breaft.

The great deference (hown by the Egyptians towards old men, was common to all the moft ancient nations of the earth. It is the only refpect known in favage life; and civil government originated through its infuence, and not from paternal authority, which could never extend beyond a family. Royalty is de-

* Ger. IToodt, de Partus Expofitione et Nece apud Veteres. Liber fingularis. 
rived from the power of the caciques, or captains, chofen by the old men to command expeditions where they themfelves could not act. This appeared to me moft evidently, when my ftudies were directed to trace the origin of focial life in America, where, from being more nodern, it is less obfcure.

As the ancient inhabitants of our continent in general have given by far too much latitude to paternal power; had this, inftead of the authority of the old men, been the foundation of government, a real def: potilm would have refulted in the ftate, as well as in each family. Yet we find no fuch effects in any country; and, if the Chinefe pretend the contrary, they are grofsly miftaken. When one hundred and twenty kings, or great caciques, reigned in China, not one of them all dared to call himfelf fatber and mother of the ftate: but as foon as the emperors, by force of arms and every fpecies of injuitice, had expelled the kings, they affumed whatever titles fuiced their fancy. Thus the cafe of the Chinefe was exactly the fame with that of the Romans; when they had fatbers of the country, their liberty was gone. Let all the dictionaries and languages of the world be examined, and they cannot lead to the flighteft idea that ever, unlefs in a figurative fenfe, the title of king had any connexion with that fatber.

The government of ancient Egypt was really monarchic by the form of its conftitution. Limits were fixed to the fovereign power; the order of fucceffion. in the royal family was regulated, and the adminiftration of juftice entrufted to a particular body, whofe credit 
credit could counterbalance the authority of the Pha. raohs. The king had no right to judge or pronounce in any civil caufe, and the judges, at their inftallation, contracted the moft folemn engagement not to obey him, in cafe he ordered them to iffue an unjuft fentence. Befides the college of thirty, ftationary at Thebes, and the particular magiftrates of towns who pronounced in certain cafes *, the provinces fent deputies at times to meet in the labyrinth, and difcufs affairs of ftate, fuppofed to be relative to taxation. Dicdorus Siculus affures us, that the kings of Egypt could not tax their fubjects arbitrarily, which, he ob. ferves, is the greateft fcourge of other ftates; and then he infinuates, that the facerdotal clafs had the infpection of the finances. This leaves room to fup. pofe, that the confent of the provinces was neceflary for levying new impofts:

We now fee the error of maintaining, that the ancients had no idea of true monarchical government. Mr. Montefquieu perceived no traces of it among them, becaufe he did not look where they were to be found; and he ftops to confider the kings of fome ftates of ancient Greece, who pronounced fentences in civil caufes. But this ufage, fo oppofite to the

* Anciently, fays Orus Apollo, the magiftrates of. Egypt judged and faw the king naked-Regem nudum spetabat. The meaning of this is obfcure; and Mr. de Pauw, canon of Utrecht, does not feem to have underftood the $39^{\text {th }}$ chapter of Hieroglyphics, on which he has given notes. When the king came to the affembly of judges, he had to lay afide his cloak or upper garment, called calafiris; probably, to flotw that be did not judge himfelf, 
principles of monarchy; was never practifed in Egypt. We fpeak here of the actions of princes, and not of tyrants.

According to a fundamental law in that country, royalty was incompatible with the pontificate*. When the fervile defpotifm of the nations inhabiting warm climates is confidered, as well as what the men of fuch countries dare attempt, and how much they can fuffer, we are led to admire the wifdom of the Egyptians in oppofing this barrier to defpotifm. The want of fimilar precautions brought ruin on the nations of Afia, where the princes got poffeflion of the prieft. hood, or rendered it removable, as in Turkey and Perfia. The muftis and fudres are as little certain of preferving their dignity, as the high-priefts of the Jews, who, towards the clofe of that monarchy, feldom held the priefthood during three years. Such flaves are incapable of defending the rights of the people, becaufe they cannot protect themfelves; and if their deftiny did not depend on the caprice of the prince, it would be determined by the intrigues. of the feraglio. In Egypt, on the contrary, the pontiffs were always permanent, and the eldeft fon conftantly fucceeded his father in that office, nearly in the fame manner that it remained in the family of Aaron, be. fore the Hebrews became the fport of defpots.

- As Herodotus faw the ftatues of all the kings, and thofe of all the pontiffs in particular, it may be confidered as a proof that, before the time of Setbon, no pontiff was ever king. Perhaps, Sethon would not abdicate the pontificate when he came to the throne. 
At length, however, from fome caufe unknown to us, it happened in Egypt that Sethon, who inherited the prielthod, attained the throne likewife. The two powers being thus united in the fame perfon, the ftate became fo completely overturned, that it could never afterwards be replaced in its former equilibrium. 'The foldiers murmured, becaufe fome of their lands were confifcated; and the people complained that the military had betrayed the country at a moment when particular interefts thould have yielded to the public good. In the midnt of thefe troubles, that the mafs of power might be divided, twelve governors were chofen to reign jointly. But this oligarchic conftitution could not re-eftablifh the monarchy, becaule it was never effectual even in a republic, although fo frequently tried in ancient times. The refult of this was real defpotifm, which continued from the time of Pfammeticlsus to the invafion of Cambyles. All thofe princes kept in pay a crowd of mercenaries, who, ever fince the world exifted, have been the inftruments and fupport of arbitrary power. At this epoch fhould be fixed the evident change which took place in the character of the Egyptians, who then began to hate their kings. Even Amafs; to whom they were in appearance reconciled, had to keep a ftrong Greek garrifon in Memphis, to guard himfelf in the midft of his dominions againft fubjects, who had once been enthufiaftic in their attachment to the Pharaohs. They pardoned many vices and weakneffes in thofe princes, and even allowed them to reign, when deprived of fight, as we find from feveral inftances; for the Egyp. 
tians were much aflicted with cecity. It is furprifing that in other eaftern empires, particularly in Perfia, Mogul, and Turkey, where the blind might be capable of governing, a quite contrary regulation has been eftablifhed. Were any thing of the kind now to happen in the monarchies of Europe, the lawyers would molt probably be puzzled to folve the difficulty; but the Egyptians founded their conduct on birth-right, which, among them, was facred and inviolable. They conceived it therefore to be unjuft to deprive a perfon of his patrimony on account of an indifpofition, already fufficiently fatal in itfelf. This might be admitted with regard to private fucceffons; but, when the obligation of governing a people was annexed, they fhould at leaft have given tutors to their blind princes, among whom we find the children of Sefortris and Pharaoh Anyfis. Were we to believe Herodotus, it would appear that the cecity of the latter in particular may be confidered as having been productive of misfortunes; for it was in his reign that the Perfians invaded Egypt *.

When the reigning family was extinct, the crown became elective; and we have all the formilities ufed on fuch oscafions minutely defcribed by Synefus. The foldiers and priefts alone had active and paffive votes, alth Jugh Diodorus pretends that the reft of the

* The name of Pharaoh Anyfis is not found in the dynafties of Manetho, becaufe it was merely borrowed. Bocchoris is generally believed to be the fame perfon with Anyfis. Cecity, however, was not incurable in Egypt, and this might have influenced the legillator.

people 
people were equally noble with the military and facer. dotal tribes. But he fhould at leaft have excepted that unfortunate clafs, fo much detefted in Egypt, and not even permitted to enter the temples. We have al* ready fpoken of thofe men, who appear to me to have been Africans of a foreign origin. They fpoke amongft themfelves the Punic language, and were held by the Egyptians in a ftate between perfonal flavery and liberty. This was likewife the cafe with the Helots at Lacedæmon, the Corynophores at Sicyon, the Peneftes in Theffaly, the Clarotes in Crete, the Gymnites in different parts of Greece, the Profpelates in Arcadia, the Leleges in Caria, the Mariandynes at Heraclea, and finally the Jews, who, after the expul: fion of the thepherd kings, were exactly in the fame condition. Herodotus fays pofitively, that the Punic language was fpoken in the neighbourhood of the town of Apis, and the lake Mareotis, amongft certain families fubjected to the Egyptians *. This caft; fo much abhorred by the Egyptians, formed at length; according to every opinion, the republic of robbers; and Strabo defcribes the little monarchy of: the Jews as degenerated likewife into a confederation of banditti. We have reafon to believe, that flaves, employed in cultivating the earth, are liable to contract a peculiarly bad character. Several focieties have

- The language fpoken of here muft not be confounded with the Carthaginians. It was properly the Libyan idiom. 'As the Egyptians came originally from Ethiopia, they neither underftood Arabic, Libyan, Phenician; nor the jargon of the Jewis; which feems to have been a dialect of the latter. 
been formed in America by negroes, who efcaped from the planters; but their policy and laws are always fo wretched, that, like the Paulifts, they be. come republics of thieves.

As the military in Egypt were far more numerous than the priefts of the firft and fecond rank, the prophets had a vote equal to one hundred foldiers, the comafte to twenty, and the zacori to ten *. All the meafures taken to procure tranquillity in thofe critical. times, when the ftate floated'between contending parties, could not prevent the elections from being frequently difturbed by the intrigues of the candidates. Some traces of this confuiron are fuppofed to be found in the hiftory of the feventy Pharaohs, who reigned during as many days, probably from having difputed. concerning the plurality of votes. This ftory could not have been founded, as people pretend; on an irruption of foreign enemies, who in lefs than three months inflicted death on feventy: of the governors of. Egypt. The whole number of prefectories did not exceed twenty-feven, as we perceive by the conftruction of the labyrinth, where the deputies of the dif ferent nomes affembled, previoufly to the conquelt of the Perfians $f$.

* Prolato alicujus ex candidatis nomime, militis quidem manus tol lunt, comafie vero et accori et propbete calculos ferunt; pauci aliqui; Sed quorum pracipua efi ea in re audioritas, prophetarum nempe; calculus centum manus aquat. Comaflaram viginti, zasororum docem. Syn. de Providen.

t. This number is found in all the copies of Strabo; but, in my opinion, the nomer confifted only of twelve great, and as many. croall. 
In very ancient times, the kings were confecrated at 'Thebes; but that ftrange ceremony was afterwards performed at Memphis. The prince carried the yoke of the bull Apis, and a fceptre made like the Theban plough, ufed at this day in cultivating the fields of Sais, and fome parts of Arabia, as we find by the figure publifhed by Mr. Niebuhr.*. Thus equipped, he was led through a part of the town, and thence to the Adyton, which feems to have been a vault. Father Martini, by the moft whimfical idea poffible, fuppofes it to have been the town of Abydus, eighty-three leagues diftant from Memphis. That man mult have imagined that the fame mode prevailed in Egypt as in his own country, where the kings go from Paris to Rheims to be confecrated.

When a prince was elected from the military clafs, he paffed, at the moment of his inauguration, into the priefthood, and this required fome particular ceremonies moft probably as well as oaths. The Pharaohs could in no cafe difpenfe, as we have already obferved, with fwearing that they would neither intercalate a day nor a month in the undetermined year, to render it fixed or lunary. In this point they kept

- Scholiaft. German. in Arat. The Scholia of Ariftophanes, on the Comedy of the Birds, fay, that, on the top of the fceptre of the Egyptian kings, was the figure of a ftork, and, on the other end, the figure of a hippopotamus. But they feem to have had different kinds of fceptres, according to what is handed down by the ancients; and the moft common of all reprefented a plough. This was carried by the kings, as well as by the prietts of Egypt and Ethiopia. 
their word more religiouny than in many others of much greater confequence.

As thole, who attained the throne by the voice of the foldiers and priefts, always gave the name of the town where they were born, and not that of their family, to the new dynafty, it is not extraordinary to find in hiftory the Pharaohs of Elephantis. Chronologifts, by not attending to this natural fact, have been forced to invent a particular monarchy in the little ifland of Elephantis, which was not more extenfive than a country-feat in Europe with walks and gardens. The valley of Egypt grows very narrow immediately above the town of Ombos; and by even allowing this pretended kingdom all the territory on the banks of the Nile, it could never be independent either of the kings of Ethiopia or of Egypt.

Marfham is the firf author who ever pretended, that Egypt confifted anciently of feveral kingdoms; and it is to be lamented, that a man, who had acquired fo much erudition, fhould have been deficient in genius and judgment. He was perfecuted by fanatics as an unbeliever; and never was any man more credulous; for he pretended that the Egyptian monarchy had been founded in the year immediately following the deluge; and what he relates of Cham, who is called by him the firf king of the Egyptians, is more worthy of a Jewith rabbin than an Englifh chronologift: Neither Cham nor Meftrain was ever fpoken of in ancient Egypt, which undoubtedly de. rives its name from the word $K y p t$; and De Hoorn believes, that the fame appellation was common to a YOL. II. 
part of Ethiopia *. Unfortunately, too many writer have introduced Jewifh traditions into hiftory; and, from that circumftance, the progrefs of knowledge has been greatly retarded.

The Egyptians undoubtedly in fome points exaggerated their antiquity. When they fpeak of perfons who lived a thoufand years, it is clear, fays Pliny, that they at firft counted by lunations $f$. But, in fact, the period attributed to the life of one perfon might be the duration of a dynafty or family, accord. ing to the manner of fpeaking in the Eart. Let it be fuppofed, that the tribe of Beni-Wafel had been fcattered throughout the heights of Thebais during fix centuries; the Arabs, who never count by the lives of individuals, would fay, that the age of Beni-Wafel was fix hundred years. This invariable manner of bearing the name of their founder, is weli adapted to preferve the epoch of a race of men, who have no ar: chives. The fame mode may perhaps be found among the free hordes of Tartars; but thofe who are fub. jected, preferve only the genealogy of their kans, whofe families become frequently extinct.

*- Bochart has abufed De Hoorn, without any neceflity, concrrning what he fays of the Ethiopians. Although the Greeks coined the word Aitbiops to denote a race of black people, the derivation of it might perhaps be concealed in the term Kopt or Kypt.

+ Annum enim alii affate unum determinabant et alterum hyeme.... Sinidam lune fenio ut Egyptii, itaque apud cos aliqgi, et fingula annorum gixiffe, millia produniur. Lib. 7.-"I have decked my bed yith tapeftry and linen of Egypt." Proverbs, chap. vii." 
The Dynafties of Manethon, however, are not neceffary to prove the great antiquity of the Egyptians; for it is demonftrated by the progrefs they had made in the arts in very diftant ages. At the conqueft of the Macedonians, they were fo far advanced, that nothing was wanting to the greateft degree of perfection, but that elegance and nicenefs of tafte, which can never be attained by the inhabitants of the Eaft; becaufe of their defective organs, and difordered imagination. The manufactures of glafs and tapeftry, fo celebrated under the Ptolemies, had been eftablifhed long before the days of thefe princes; and the carpets of Egypt particularly formed part of the merchandife tranfported into Afia by the ifthmus of Suez. Of this more fhall be faid, when we come to examine what might have been the annual revenues of the Pharaohs, to whom the firft legiflators of Egypt had prefcribed many rules and maxims preferved in the Hermetic Collection. From that book the paffages in Diodorus were probably extracted, which declare that thole princes could never keep flaves, whether born in Egypt, or purchafed in foreign countries. They were required to take their attendants from children of priefts, who did not enter into the fervice of the court until they had attained their twentieth year. This law was far from being obferved; for when the Pharaohs introduced flaves into their feraglio, they committed them to the care of eunuchs, who were certainly neither freemen, nor chofen out of the facerdotal clafs. Diodorus pretends likewife, that the kings were obliged to perufe all the letters they re- 
ceived, to attend prayers daily, and hear fome pafiage read in the Annals of the country. Many pretexts might however have been found for difjenfing with fuch ceremonies, when the allurenents of pleafure, or idlenefs, which is the greateft enjoyment in warm clinates, rendered them irkfome.

It cannot be too frequently repeated, that, in reading the hiftory of Egypt, the laws really in force fhould be diftinguifhed from the ancient inftitutions found only in books. Had this not been the cafe, the priefts could never have fpoken of a long lift of indolent kings, who flumbered in feraglios, and re: ceived, like the reft, fepulchral honors. We have reafon to believe, contrary to the common opinion, that the people never poffeffed the right of refufing burial. Such a cuftom would not have produced any good effect in Egypt, where the father was always fucceeded on the throne by his eldert fon, as long as the royal family remained. In that cafe, the young prince murt have been the implacable enemy of thofe who refufed to let his father be interred; and it was, befides, an eafy matter for him to have the mummy con: veyed fecretly into fome vault.

Diodorus indeed fays, that the Pharaohs, who, according to him, confructed the two great pyramids, had not dared to have their bodies depofited there, through fear that they might be thrown out by the people; but this was a vulgar report; totally un. known to Herodotus. Very little reflection is neceffary to perceive that thofe princes muft have had more fenfe than to rear pyramids for their tombs; while 
they knew fo well that their interment there was impracticable. The Greeks, having once taken into their heads that the pyramids were the tombs of the Pharaohs, would never allow themfelves to be perfuaded to the contrary, although the Egyptians declared pofitively that no corple of any king was ever depofited in any of the pyramids, and that thofe mo: numents were erected by the nation, and not by particular princes. Hiftory contains one fact very decifive in proving that the Egyptians never thought of refufing burial to their bad kings. One of the defpotic Pharaohs, called Apries, who was fuppofed to have committed many atrocious crimes, incurred the refentment of the people to fuch a great degree, that they infifted on having him delivered into their hands, when he was vanquifhed by Amafis. After he had been frangled in their fury, his body was placed in the tomb of his tathers, at the entrance of the temple of the Minerva of Sais, where all the Pharaohs of the Saite tribe were depofited.

The opinion hazarded by fome modern writers, concerning the anonymous kings found in the Catalogue of Dynafties, thould not be credited. They pretended that their names were fuppreffed, becaufe their hands had been fullied with blood, or ill-acquired riches. As the memory of tyrants muft be devoted to execration in every age, it would be rendering them a fervice to efface them entirely from the annals. But the priefts, who were not fo filly, wrote both names and events with great fidelity *.

- Eufeb. Præpar. Evang. lib. 10. 
Bad princes no longer fear future cenfure, fince flattery has fucceeded in corrupting hintorical faith; and this evil originated among the Greeks and Romans. If the Catalogue of the Dynafties contains fome anonymous perfors, that circumitance fhould be attributed to the negligence of the compilers. Eufebius, for example, has omitted the names of feveral Pharaohs preferved by Julius Africanus; and we know to a certainty that the Hiftory of Manethon mentions Acbthoes as the molt cruel and unjuft of all the kings of Egypt. Thus we find how little the priefts were difpofed to fupprefs the names of tyrants; otherwife, the monfter Achthoes muft have been now unknown. Orus Apollo affures us, that, when the name of a wicked king was to be inferted in hieroglyphical records, it was ordained to be written in alphabetical characters*. The priefts denoted foreign ufurpers by fymbolical terms familiar to all the people; and every Egyptian knew that the king of Perfia, called by us Ocbus, was furnamed among them the Ajs.

- According to a very ancient cuftom, the high prieft had to pronounce a public difcourfe when the corpfe of a king was carried to the tomb, after a mourning. of feventy days, which we know was the precife time neceffary for the embalmers to prepare the mummy. In this harangue confifted the judgment

* Regem autem pefsmum frisificantes, anguem pingunt in orbis fguram: 'cujus, caudam ori almovent: nomen-vero regis in media revolutione frribunt. Hiern, lib. 1.-Alphabetical characters are fometimes feen with the hieroglyphics on the monuments ; and of this what Orus fays herc is a proof. 
pafled on the dead Pharaohs, who were prailed for different qualities, but chiefly, as Porphyry fays, for fobriety, becaufe that virtue fuppofes many others, particularly in fovereigns.

Private people were probably never refufed burial, unlefs when the creditors oppofed it juridically. This made the Greeks imagine that people were found among the Egyptians, who advanced money on an embalmed body, and that the contract was juftified by law. This mifiake is truly ridiculous. As the want of burial was confidered as a fpecies of infamy, the creditor arrefted the corpfe of the debtor, and did not allow it to be buried until the relations payed the debt. Such pretenfions could be difcuffed before the ordinary magiftrate of every town; and it was abfurd to fuppofe that one tribunal, eftablifhed at Memphis, had to acquit or condemn all thofe who died in Egypt., It was befides alleged, that the fentence could not be pronounced until after a rigid examination of the whole life of each perfon; and this, inftead of a fingle tribunal, would have required onefourth of the nation. In fact, the power of feizing on the dead body of a debtor was only a modification of the Egyptian law, which prevented him from being imprifoned while alive.

As the Pharaohs were generally inftructed in the fciences from their infancy, many of them wrote books; but they have had the misfortune to be entirely deftroyed. This has been the cafe with fo many of the kings of antiquity, that we are almolt tempted to believe, that their productions were not worthy of 
being preferved. The works of Alexander the Grea:, of the emperor Auguftus, Tiberius, Caligula, Claudius, Nero, Ptolemy Philometer, Archelaus, and many other princes, to whom might be added Hannibal, Lucullus, Sylla, and Mecænas, are fo entirely loft, that even the titles of the greater part are unknown. The leaft part of the writings of Julius Cæfar now remain, and a kind of veneration for the memory of Marcus Aurelius and Julian has made them exceptions to the general rule. Yet, in the days of Pliny, fome books were ftill found with the name of Necepfos; but whatever Firmicus may fay to the contrary, thofe works feem to have been produced in later ages by fome famifhed Greek, who boldly took the name of Pharaoh Necepfos. That prince received the moft pompous titles from the aftrologers; they ftyled him the chief of authors, and fuperlatively learned in aftrology, becaufe he had really written on the influence of the ftars. His works are therefore not fo much to be regretted as thofe of fome other Pharaohs, who appear to have been truly defirous of information; yet we muft not believe that they ever made fuch experiments as Herodotus has attributed to Pfammeticbus. - That prince, fays he, cauled two infants to be reared, without having an opportunity of hearing any converfation : his object in this was to know what language the children would ufe, that he might terminate all the contefts of the inhabitants of Egypt and Phrygia, concerning their refpective antiquity. Herodotus was credulous enough to believe that the firft word they fpoke was Phrygian.

Thofe, 
Thofe, who are defirous of knowing the origin of this abfurd ftory, may be fatisfied that it was founded fimply on the circumftance of Pfammetichus having given fome Egyptian children to be inftructed in the language of the Greeks. With regard to the Phrygians, they were ridiculed with the name of Beccoelenes, on account of their pretended antiquity: they called themfelves older than the moon, and cited, as a proof of their pretenfions, the experiment made in Egypt, when the children uttered the word beccos*.

The predominating paffion of the Pharaohs was building; and this led to the erroneous opinion of their great riches. Under their fway no commerce was carried on either in the Mediterranean or Red Sea; and, although the Arabs and Phenicians brought caravans through the ifthmus of Suez, yet the balance of that trade was not always in favor of the Egyptians. Afia furnifhed them with oil of olives, incenfe for the facrifices and fumigations, Judaic bitumen, refin of cedar, drugs for embalming bodies, myrrh, and aromatics. Such articles were never cheap in ancient times. Thus when we fuppofe that the Egyptians, by means of their grain, linen, tapeftry, glafs, and other wrought wares, could barter with the caravans of Afra, it was not a fource fufficient to enrich the kings, who levied no impofts on the land poffeffed by the militia or the facerdotal clafs. Their only refource was in cultivating the royal do-

* This word fignifies bread in Phrygian, whicb I believe was called bebo in the Egyptian language. The difference between this and beccos was not very great.

mains, 
mains, exacting a trifling toll on the Nile; and taxing to a certain degree the property of private perfons. The commerce of Ethiopia was certainly very advan. tageous for the Egyptian merchants, who received thence great quantities' of gold duft, part of which now paffes to the weftern coaft of Africa; fome circulates in Barbary; and the reft fill comes to Cairo. Mr. Maillet, however, exaggerates greatly, when he calculates the gold tranfported annually into Egypt by the Numidian caravans at twelve hundred quintals. Bofman favs pofitively, that, in his time, all the coaft of Guinea afforded only fevèn thoufand marks, which: Mr. Maillet, or his compiler, the abbé Mafcrier, has converted into quintals*. The ancients amplified nearly in the fame proportion what related to Arabia. Felix : that poor and barren country has frequently. excited admiration in the inhabitants of other countries, who would lofe prodigiounly by an exchange.

Nothing is more uncertain than the exiftence of thofe gold mines, faid to have been poffeffed by the kings of Egypt. Hecateus eftimates their product, in his common way, at an incredible fum; and Diodorus places them on the confines of Arabia, Ethiopia; and Egypt. Their fituation mult therefore have been nearly the fame with that of the emerald mines, and, confequently; beyond the territory of the Egyptians. That diftrict belunged either to the Troglodytes or Ethiopians : and ic was really the latter who collected the gold among the fand of rivers and torrents, or

* Defcription of Egypt, part ii. 
procured it in the manner now practifed by the Africans.

In fact, the revenues of the Pharaohs were far from amounting to twelve hundred thoufand pounds fterling annually, prior to the reign of Pfammetichus, who made great changes in the finances, and in commerce. Under the Ptolemies, Egypt had the whole commerce of India, of the eaftern coaft of Africa, Arabia, and Ethiopia, befides what was derived from the navigation of the Mediterranean. Yet the annual revenue of Ptolemy Auletes did not exceed two millions four hundred and twenty-two thoufand pounds. But, as that prince, was faid to have neglected his finances more than any of his predeceffors, we thall examine the ftate of the revenues under Ptolemy Philadelphus, when Egypt, according to hiftorians, was exceedingly flourihing.

Philadelphus received every year two millions eight hundred and fixty-feren thoufand pounds in money, and fifteen millions of fmall meafures of wheat*. Thus from his reign to that of Ptolemy Auletes, father to Cleopatra, the derangement of the finances had produced a diminution of only four hundred and forty-five thoufand pounds. - This was far from being an object fo confiderable as Strabo pretends; and Philadelphus muft have had other important poffeffions out of Egypt, otherwife he could never have maintained fuch an army as is mentioned by Appiant.

* Iero on the ninth C apter of Daniel. The number of meafures of grain feems exaggerated. :t Praf. ad Libros Bellor. Civil. 
The regiters of the court of Alexandria make the whole armed force to have confifted of two hundred and forty thoufand men, who, if maintained and paid as at the prefent day, would have confumed three millions and a half annually. It is very poffible that the troops were not fo numerous; for, befides the fufpicions fuggefted by Polybius, many are perfuaded that Appian doubled the real number of horfes. That man was born in Alexandria, and he lied for the honor of his country.

When Egypt was fhut towards the Arabian gulph, as well as the Mediterranean, the revenues of the Pharaohs could never have amounted to twelve hundred thoufand pounds. It thould be obferved, that the Ptolemies feem to have referved the commerce of India for their private advantage; and the wares of others had to pay very heavy duties at different ports on the Nile. Thus Philadelphus received the greateft part of his riches from another fource than Egypt, which did not then contain more than three millions of inhabitants. Jofephus was guilty of an unpardonable error in making its population amount to eight millions in the reign of Nero, after all the miferies the country had fuffered under the laft Ptolemies and the firft Cafars.

We do not here make any allowance for the difference which fome have imagined in the value of fpecie; for it muft then have been nearly the fame as at prefent. The quantity is now indeed much greater; but the circulation has alfo become far more extenfive than in former times. When Philadelphus reigned 
in Egypt, the ufe of gold and filver was fcarcely known in France, Spain, and England; but thofe metals had no circulation whatever in either Germany, Po. land, Sweden, or Denmark. As fpecie was then concentred among the nations inhabiting the coafts and iflands of the Mediterranean, that abundance prevented any great augmentation of its value.

That the riches of the ancient Pharaohs have been greatly exaggerated muft appear from the following direct proof. Herodotus, in a fpecification of the tributes levied by Darius, fon of Hyftafpes, on the countries he had fubdued, mentions the contribution of Affyria, including Babylon, as conffting of one thoufand talents, and five hundred emafculated chil. dren annually for the ufe of the feraglio. But the whole of Egypt, Barca, Cirene, and ánother canton of Africa, had to pay altogether only feven hundred talents. That fum indeed was exclufive of the fupplies in grain for maintaining an hundred and twenty thoufand Perfians, and the produce of the fifheries on the lake Maris; but the laft article was never equal to what the Greeks have childifly imagined. This fum, however, was very trifling in comparifon of what Egypt muft have paid, had the Pharaohs poffeffed fuch enormous finances; for Darius certainly pre. ferved fome proportion between the tribute and the revenues of the refpective ftates.

Thofe who have written hitherto on Egypt, pre: tend, that it was greatly enriched by the fpoils Se. foltris had brought from his expedition, when he laid the whole habitable world under contribution. But this 
this error originated from the interpreters, who, in fhowing ftrangers the temples and monuments of Egypt, inpofed on them with fables, which increafed by reperition. Diodorus fays, that Sefoltris appeared in the ftreets of his capital drawn by the deputies of the fovereigns of the earth; and Lucan went fill farther, by making him harnefs the kings themfelves. In this manner fictions are fpread abroad, and people are always found to exaggerate what others have dreamed.

The three firft Ptolemies really occafioned the opulence of Egypt by concentring the greateft commerce then known on the ancient continent. As this wealth was founded on articles of the molt defructive luxury, fome able politicians at Rome invented an oracle of the Sibyls, forbidding the Romans to carry their arms into Egypt; and another equally fpurious was faid to be delivered at Memphis*: But Auguftus, who ridiculed prophecies, did not hefitate to invade Egypt whenever he found an opportunity; and ever fince that celebrated epocha, the Romans continued to degenerate, as the politicians had forefeen.

An Egyptian law, tranfmitted by Diodorus, has led many of the learned to believe that gold and

* Haud equidem immeritò Cumane carmine vatis Cautum, ne Nili Pelufia tangeret arva Hejperius miles.

Thefe verfes of the Pharfalia are a paraphrafe of the four following words faid to be extracted from the books of the Sibyls : Miles Romane, Egyptum cave. 
fiver money had long been ufed in that country? but nothing is more erroneous than this fuppofition; for thole metals continued to be weighed, as we find practifed by thofe who had to difcharge their vows at the temples for the health of their children. The firt current coin of Egypt was ftruck by Aryandes, under the dominion of the Perians, who, as Sperling jaftly obferves, had never any great quantity of fpecie in circulation*. It appears, indeed, that what had been iffued was entirely drawn back by the annual tributes; for the Arabs, who fearch among the ruins cf Egypt, and even fift much of the loofe fand, have never difcovered one fingle piece. None of the medals found there are older than the reign of Alexander. They either belonged to the Ptolemies, or to the Egyptian towns which were allowed the privilege of having their own coin under the dominion of the Greeks: thefe were Pelufium, Memphis, Abydus, Thebes, Hermopolis, and the great city of Hercules $t$.

Among the different people, to whom the ancients and moderns have attributed the invention of money, the Egyptians were never mentioned, not even by Pollux, who enters intu many details on that fubject. Count Caylus was certainly deceived, when he believed that fmall leaves of gold folded together were

* De Nummis non cufis. - Sperling fays, that in his time the falfe hekels were made in Holltein. It is furprifing that Egyptian medals were not forged there likewife.

+ Vaillant, Hift. Ptolem. ad Fidem Numifmatum accommodata, 104. 
ufed there as current coin*. The kind of bracelets, to which he alludes, are only found on the body, or in the mouth of fome mummy; and, therefore, they. fhould be confidered as amulets either phylacteric, or merely reprefenting the leaves of the perfea. The merchants of Egypt were prohibited by law from mark. ing their ingots with a falfe quality, or weight; and. every perfon could employ fcales, as in the payments. by thekels, when they were fufpected to be too light. It was with the Egyptians, as among the Hebrews, whofe thekels were not coined until the building of the fecond temple; and thole nations remained too clofely connected for the one to have employed. money while it was unknown to the other.

- This at firft feems to indicate a friking refemblance to the Chinefe; but by examining further we perceive it to be precifely the contrary. The hiltorians of China affert, that money was ufed there in very ancient times; and to fupport this they have had recourfe to the fabrication of falfe medals. The opinion generally received is, that $\tau_{\text {cloing-tang, who is faid to have }}$ mounted the throne one thoufand five hundred and fifty-eight years before our era, caufed different metals to be calt in molds to facilitate commerce in the different provinces of his dominions. But afterwards it became neceffary to withdraw all the filver and gold pieces out of the hands of the Chinefe, becaufe they counterfeited them fo exactly, that no perfon could poffibly diftinguifh any difference. Yet the prefent method adopted in China is far from hav-

- Colleçion of Antiquities, vol, ii. 
ing entirely corrected that abufe; becaufe they have fubftituted unjuft weights and fcales for falle bullion. All the merchants there are as cunning in the art of weighing as the Jews and Egyptians; and the fame roguery muft always take place in every country deftitute of current coin. The metal is affayed only by the touch-ftone, which never indicates the quality with the nicelt precifion, in the opinion of the molt able judges, who certainly are the Jews. Such is the difference between theEgyptians and Chinefe; the firt difcovered a weaknefs of penetration in not inventing money, and the latter a want of probity by rendering the ufe of it impracticable. The gold and filver fpecie, introduced into the com merce of Egypt by the Greeks, remained always unadulterated, and did not require to be withdrawn, as in China.

The pyramids, the obelifks, the temples, and the exaggerations of Homer, made fo many authors believe that the Pharaohs were immenfely rich. But the materials of all thofe works had colt them nothing, and their revenues were fufficient to pay the workmen, who anciently in warm countries did not earn one tenth part of the wages now common in Europe. The rate of labor is always regulated by the expence required for the phyfical wants of the workman and thofe of his family. We have already obferved how little was neceffary for nourining a child in Egypt, when that country had no exterior commerce, which never fails to affect in fome de. gree the price of provifions; and the grain exported into Afra by the caravans was not of confequence 
enough to be mentioned. The lands, poffeffed by the Pharaohs in their own right, probably fufficed to pay for the food, and perhaps the clothing, of the laborers; and we may conclude that litthe other ex. pence was neceffary.

- Statues of bronze, of gold, fifver, and ivory, do not appear to have been in any meafure fo common in the edifices of $\mathrm{E}_{\mathrm{g} y \mathrm{pt}}$ as in thofe of Greece and Italy; and it is not impoffible, that the Athenians expended more money on the Atatue of Minerva than Phàraoh Amdifis in liewing and tranfporting one of the obelifks of Sais. When the ancients mention a prodigious circle of gold placed by the Egyptians around the tomb of Ofymandias; and $a_{\text {Itatu }}$ of the fame tnetal erected in the Delta, they confeffed that they fpoke of thofe things from hearfay; but. the difference is very great between, feeing a huge mafs of gold and defcribing it in romance, The Egyptians/were not even permitted to sarry goldinto. the temple of Heliopolis ; and the Jews; would have acted yifely by obferving the fame policy mbut they continued to heap ap treafute in their temple at Jerú falem to be conftantly pillaged, as is ever the cafert where riches are placed in churches.

By the ceremong of the inauguration of the Pha. raohs we perceiye, that thore princes were far from difplaying at their court the infulting pampt of thed eaftern defpots. Then furely was the timenforther greater oftentation; and yet the fcholiaft of Germatnicus fays, that the kings of Egypt, on that days: nicus lays, that the kings of Egypt, on that day wore a very modelt tunic, a collar, a Iceptse, and a 
diadem. The latter, refembling wreathed:ferpents, was probably made of gold; and the emperor Titus is fuppofed to have worn fomething of the fame kind at the confecration of the bull $A$ piss. $\triangle \mathrm{He}$ did not; however; carry the yoke of that animal, like the Pharaohs, becaufe it would have been the fignal of revolt againf his father, and yet his conduct on that occafion feemed rather fufpicious *:- As the kings of Egypt conformed themfelves fcrupuloufly to the die:têtic fyftem until Pfammetichus, "r their tables occafioned little expences: They knew well that the firft inhabitants of Egypt had not invented that regimen to gratify any principle of aufterity, but entirely from motives of health: The fame thing was vifible in the manner of living adopted by the priefts, whofe very beds were woven with leaves of the palm-tree, in order to avoid a diforder which would have rendered them impure; and not, as Perfius fays, to lay. themfelves under continual penitence. It was at Röme that thofe beds of down, fo much efteemed in ancient times, were purchafed from the Egyptians, who had always the good fenfe not to employ them for their own ufe $f$.

*. When Titus crowned himfelf at the confecration of Apis, he was only a private perfon. 2uam fuspicionem, fays Suetonius, auxit poflquam Alexandriam petens, in confecrando apud Memphim

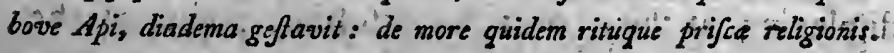
In Tito', vii.

+ It is mentioned in an Epigram of Martial, beginning with thefe words: 2uid totus a Nilo, \&c. This commerce proceeded from the great quantity of geefe fed by the Egyptians, as appears in the $2 \mathrm{~d}$ Section. 
We have already had occafion, in a feparate Sec. tion on the liberal arts, to fpeak of the ancient manner of dividing the people in Egypt. At prefent it thould be added, that the election of the twelve governors, who were to reign conjointly in that country after the death of Pharaoh Setbon, is the Atrongeft proof that the Egyptians were originally divided into twelve caftes, of which it is fearcely to be doubted thofe governors were chiefs, as we find among the tribes of the Jews. But befides this divifion, another more general was eftablifhed, according to which the feople were confidered as forming three great bodies. The fame thing is obfervable with the Coptes, or modern Egyptians, whofe Mebachers reprefent the Calafires and the Hernotybes, or, what is the fame thing, the military families. According to Herodotus, they once could have brought into the field four hundred and ten thoufand men; but an abfurdity of this nature does not require to be refuted.

At a time when money was very fcarce, the Egyptians muft have been obliged to affign lands to the foldiers; and afterwards, we may fuppofe, many difputes took place relative to the produce, which, from the diverfity of foil, could not be alike on a given fpace. To remedy this inconvenience, the legiflature ordained that the military portions thould circulate continually, paffing every year from one foldier to another, fo that the perfon, who had at firf a bad lot, received afterwards a better. By this operation, the property of lands was entirely taken away from the military order, who were reduced to 
ON THE GYPTIANS AND CHINESE.

the ftate of mere ufufructuaries. Afierwards a law was made to prevent any foldier from cultivating the ground, following commerce, or exercifing mechanical arts.

It is very aftonifhing indeed, that this difpofition of the Egyptian laws hould have been introduced in certain books written with the intention of juftifying the fyltem of excluding nobility from commerce; for in fact the two cales admit of no refemblance whatever. The Calafires and Hermotybes were ob. vioufly in the pay of the ftate; and therefore the legillature properly prohibited them, as foldiers, from trading. No perfon was abfurd enough to propofe that fuch of our modern nobility, as ferve in the army, thould apply themfelves to commerce. The idea was confined to thole, who, not being employed by the ftate, could in no manner be compared to the Calafires, and Hermotybes, who were conftantly on fervice. When it is meant to decide political queftions by the authority of ancient hiftory, great care fhould be taken to prove that the cafes in queftion are exactly alike: otherwife nothing can refult but a confuín of ideas.

As the inhabitants of lower Egypt are, perhaps, born with greater frength and vigor than thole of Thebais, it was fo ordered, that the greater part of the military families were found in the Delta. The fame arrangement has been fuppofed to have taken place in India, where the military families of the Rayas and Nairs inhabit likewife the moft rorthern parts of the country. 
The eftablifhments of the Egyptian militia com: prehended chiefly the town of Sais, where Minerva, who was chofen by the foldiers for their gyardian, had a famous temple. Thus we find the fcarabee fculptured on all the military rings; for that infect was always confidered as one of the principal fym. bols of the Egyptian Minerva. The fame goddefs in fome monuments appeared like the Pallas of the Athe. nians, who likewile placed their warriors under the protection of that divinity, as the artifans were under that of Vulcan.

With regard to the terms Calafires and Hermotybes, by which the two corps of Egyptian militia were denoted *, they have hitherto never been fatisfactorily interpreted. ln my opinion, they were derived folely from the form of the clothing, and not from the armor, the moft remarkable part of which was a huge buckler, like that ufed by the Gauls. In cowering the whole body, it impeded every movement; and as the Egyptians formed themfelves into platpons to a c feparately, the enemy preffed them together fo clofely, that they became incapable of refiftance. Cafar defcribes a defenfive armor of fome German people, which occafioned their defeat nearly, in the fame manner. Large bucklers were generally rejected by the Romans, Greeks, Macedonians, and even

- The word Calafiris fignifies the garment geperally, worn in Egypt ; and we find the term Hemitybion for another particular kind of tunic. The Latin tranlator fancied that this word was originally Greek; but it has only been corrupted by a Greekster mination; as well as Herinotybies: 
by the Chince, who fometimes, however, conceal thiemfelves under their fhields, by forming a kind of a tortoife.

The bad principles, adopted by the Egyptians in tactics, proceeded in a great meafure from their ufing chariots in war. If we except elephants, nothing is capable of producing more diforder in attacks; and they have been tried and abandoned by almoft every nation of the ancient continent. Befides the confufion occafioned by thefe unwieldy machines, they prevent the advantage which might be derived 'from the horfes in a fandy country, fuch as the eaftern and weftern parts of the Delta, where the Egyptians encountered fo many defeats.

It is generally believed that the Egyptians wore no helmet, and this error has originated from a ftory related by Herodotus. He pretends to have obferved near Pelufium, that the heads of the Perfians fattered on an ancient field of battle were much fofter "than thofe of the Egyptians, who Shaved their hair, and never, according to him, wore any head-drefs. But they certainty had helmets of brafs, and cuiraffes rimalde of ffax, like that of Pharaoh Aniafis, which ocreated admiration in all thofe who faw them at -Sarnos, and at Eindius in the ifland of Rhodes, where the môn beautiful was cônfecrated to Minervab. This armor, defcribed by Herodotus, was remarkable for its textùre, where each thread was compoled of three hundred and fixty-five others, in allufion to the indefinite year; for the Egyptians could never refrain from their allegories, even where they were altoge- 
ther improper. Although Iphicrates introduced the Egyptian cuiraffes among the Athenian militia, yet Paufanias had reafon in rejecting them as defective, becaufe, however effectual againft fwords, or ftones thrown from flings, they could not refift a pointed weapon. Befides arms, colors, and inftruments of mufic, the formidable Calafires of Egypt, in all their expeditions, were provided with a number of birds of prey, and principally vultures, for the purpofe of divination. Orus Apollo fpeaks of this cuftom in feveral parts of his Hieroglyphics; and it is exactly obferved at this day by the Nairs and Rayas of India, who never give battle when the vultures appear fullen and quiet. The generals moft probably have a fecret of giving them vorácity, when it anfwers their pur: pofe, by means of opium; and the Marrattoes render their horfes fo impetuous by the ufe of that drug, that they are almoft irrefiftible. The Egyptians are faid to have had alfo a very numerous cavalry independent of their armed chariots, the figure of which is feen fculptured on fome of the monuments of Thebais. But by reflecting on the regular overflowing of the Nile, it is eafy to conceive that the number of horfes could never have been very great among the Egyptians, becaufe they could only be employed when the river was within its bed. This inconvenience alone, without mentioning the canals and ditches encountered at every ftep, muft have difgufted them with cavalry; and the force of their armies really confifted in in: fantry, as we are told by Xenophon: 
- What authors have written concerning Sefoltris contains fo many contradictions, that we muf conclude they fpoke at random. Some pretend that his whole life was fpent in endeavouring to enervate the military fpirit of the Egyptians, by encouraging effeminacy, becaufe he hoped by that means to prevent thofe revolts fo frequent and fatal among the militia of the Eaft. Other hiftorians, fuch as Ariftotle, affert that, on the contrary, he improved the art of war, and gave additional force to difcipline. Soldiers in that country were accultomed to be governed by the point of honor, rather than through fear of punifhment: they became infamous from difobedience to their chiefs; and nothing but extraordinary proofs of bravery could retrieve their character. The Egyptian army, however, had little to boaft of its expedition to Jerufalem; for it was no difficult mat. ter to feduce a pitiful race of men; who were van. quifhed by the greateft part of thofe who chofe to attack them.

The Calafires and Hermotybes have been accufed of cowardice in actions, where in reality they were not prefent. According to our opinion, all the national militia retired into Ethiopia in the reign of Pfanmetichus, and never fought more under the Pharaohs*. Thus they could not have affifted at the fiege of Azot; which, as. Herodotus fays, lafted twenty-nine years, and never fince the world exilted, continues

* Some authors make the number of foldiers who retired to Ethiopia amount to two hundred thoufand. But fuppofing only the half of that number, it follows that all the national militia migrated. 
he, did any place hold out fo long; for the foreign troops in the pay of the kings of Egypt refufed to affault the town. It is difficult to fay what the Calafires and Hernotybes would have done on that occafion; but they lived then peaceably in Ethiopia, and had no part in either the battle with Cambyfes, or any future operations. That prince, at the fiege of Pelufium, is faid to have formed a line of facred animals before his troops; and by that means the - Egyptians were prevénted from throwing a fingle dart. But that ftratagen is a mere fable: In the firff place, Pelufium did not require to be befieged by Cambyfes, for it furrendered at his approach; and next, it fhould be obferved that the mercenary troops of Caria, Ionia, and Libya, who were then oppofed to the Perfians, would have troubled themfelves very little about animals, not at all connected with their own religion. Thus we find the whole ftory to be the invention of fome writer ignorant of hiftory, who believed that the ancient Calafires and Hermo. tybes were fill in Egypt, when that country was fưb. dued by the fon of Cyrus.

no In China, the left fide has always been confidered as the poft of honor; but the right had the preference in Egypt. Pharaoh Pfammeticbus, who violated'at once all laws and ufages, formed the right wing of - his army with the foreign troops, and afligned the "Feft for the Calafires and Hermotybes." Thbre unfor" tưnate people, confidering thenfelves difhonored by the unjuft preference given to fafriltied Greeks and faithlers mercenaries, abandothed Egypt;" althoúgh the inhabitants of that counery were never accuf. 
ON THE EGYPIIANS AND CHINESE.

tomed to emigratę, as we learn from Clemens of Alexandria *.

Herodotus, fpeaking of this retreat of the Egyp. tian foldiers, does not agree exactly with Diodorus, who attributes their difcontent entirely to the affront they had received. The former pretends that they had been left during three years in the garrifon of Thebais by P Sammeticbus, who would not allow them to leave thofe quarters; but his account feems improbable, and he has befides been notorioully de, ceived, when he places the eftablifhment they formed fo far in the interior part of Ethiopia. It feems almoft certain that they fettled on the banks of the Aftaboras, and opened a paffage for the water of that river into the Red Sea. This artificial drain is not faid to have affected the water of the Nile; becaufe the diminution was, perhaps, too inconfiderable to be perceived.

The project of turning the Nile into the Red Sea, and of rendering Egypt uninhabitable, does not feem to have been unknown to the ancients. This is the opinion of Mr. Maas, that truly learned and eftimable author, who has produced the bent work now extant on the geography of Paleftine. Claudian, who was born in Egypt, gives us fome notion of the poffibility of changing the courfe of the Nile; but nothing of the kind was attempted until the tenth century, and what is related on that occafion appears to me as fabulouse El Elmacin and Father Lallier affert that, under the kalifship of Munftanfir, the water was completely turned away from Egypt by dikes and fuices, 
and the inhabitants began to fear a famine. As the patriarchs of Alexandria are the real metropolitans of Ethiopia, where they are reprefented by an Abuna, Michael the third was prevailed upon to carry prefents to the Ethiopians, and he fucceeded in having the works deftroyed.

It is not eafy to conceive how the Ethiopians could have been at that time fufficiently verfed in the arts to execute fuch undertakings. Towards the year one thoufand five hundred and twenty-five, Etana Denghel, who was emperor of Ethiopia, fent an ambaffador to Lifbon, requefting the king of Portugal to affif him with a number of European pioneers and architects, for the purpofe of preventing any water from defcending into Egypt. This monarch pretended that one of his predeceffors, called Lalibala by Ludolph, had endeavoyred to execute the fame project by opening a canal oppofite Suakem. That place, is about an hundred miles diftant from the Nile, according to the Portuguefe, who were incapable of accomplifing the in: tended object; and we know that they did not even make a beginning. In the year one thoufand feven hundred and fix, Teklimanout, calling hinfelf king of Abyfinia, threatened the pacha of Cairo with deftroying Egypt by drying up the Nile*. But it was eafier for an Abyfinian to fpeak in this manner to a Turk, than to execute any project of that nature.

It is not at Suakem, as the Portuguefe believed, but more to the fouth, in the eighteenth degree, that the furface of the country begins to form a continual Continuation of Eobo's Voyage. 
defent to the very fhore of the Red Sea. At that place the water of the Aftaboras, or Tacaze, might be prevented from falling into the Nile, and even that river itfelf directed towards the eaft, inftead of flowing northwards, as at prefent. This, however, would require prodigious labor, and the profit arifing from it would never compenfate for the expence. Befides, the Ethiopians would gain nothing by ruining Egypt; and if their object was only to have a communication with the Arabian gulph, it might be effected by repairing the canal formerly opened by the Egyptian deferters. That cut muft now be entirely dry, becaufe it is not marked down by Niebuhr, and the pofition on d'Anville's map is altogether ideal.

Ethiopia and Egypt feldom formed one dominion; but if thefe two countries were fubject to one prince, he might fucceed by means of dikes and Aluices to raife the Nile annually to the exact height necef fary for inundating the whole country from Syene to the Mediterranean. By collecting the rain-water fwallowed up in the fands of Abyflinia, refervoirs might be formed for fupplying Egypt at will. Something of the kind is, indeed, faid to have been attempted by the ancients; - becaufe far in the interior of Africa fome rivers are found communicating with each other by canals formed feparately by human art; but no. perfon can fuppofe that any fuch project was ever formed by the Egyptians, who, perhaps, never conceived it to be practicable. The priefts knew nearly every thing to be acquired concerning 
the caufes of the overflowing of the Nile, which they explained in a very fatisfactory manner to Eudoxus". But, with regatd to the fource of that river, they either placed it too far towards the fouth, or fuppofed that, propetly fpeaking, no fuch fpot exifted. This opinion, indeed, feems molt probable; for in all appearance a number of fmall brooks are formed in different parts fome days after the rain begins to fall in the torrid zone. The fource of the river may, therefore, be found fometimes in one valley, and fometimes in another, accordingly as the wind drives the clouds, or as they are attracted to fome partis cular mountain. Thus the Nile probably originates at certañ periods in very diftant provinces; but it cannot porfibly? proceed from the heights of the auftral heminforere, as the priefts feem to have fup

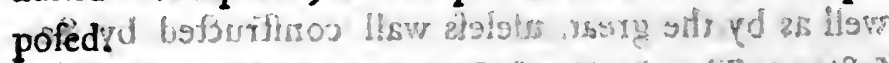
What has been faid may fuffice to give a tolerable idea tof the internal government of ancient Egypt; but long difcuffons would "be noceffary ito indicate the policy obferved towards other nations. This conduce feems to have been little underftood by the Egyptians in general, and we may cite as an example the unpardonable fault of $A \mathrm{ma}$ fis, who neglected to form a fecret treaty with the Arabs, when the power of Cyruts began to make Afra tremble. The ancients "themfelves have" obferved, that, if the Egytptians had adopted this precaution, the army of Cambyfés would never have penetrated even as far as the ifthmus of Suez. Plammetichus was guilty of $\mathbf{a}^{2}$ 
ftill more enormous imprudence in committing the defence of Egypt to foreign troops, and eftablifhing colonies there compofed of the dregs of different nations. The coaft of the Mediterranean might have remained free to the commerce of Greece; but the Greeks themfelves thould never have been ad mitted as fettlers in the cantons of the Delta. The Egyptians had already in their country too many foreign colonifts, who were allowed to live in bo. dies according to their particular laws; and this is contrary to all rules of policy one of thefe fo. cieties, compofed folely of Phenicians, poffeffed a confiderable part of Memphis; a band of Arabs were fedentary at Coptus; and the inroads of the Bedouins could not always be prevented, as we find by the contract eftablifhed between them and the Egyptians, as wivell as by the great ufelefs wall conftructed by Sefoftris 5 The Arabs of Coptus carried on a kind of traffic, and fent fome wares as far as the town called Arabia Felix, which certainly was not a country; as the author of the Periplus of the Erythrean Sea has afferted in avery pofitive manner. Thus, when the Ptolemies opened a direct intercourfe with India, Arabja Felix difappeared, and the place, where it formerly tood was tevelled entirely by the Romans. The Ethiopians had an eftablifhnent in higher Egypt ; and the weftern Africans, who, in my opinion, com pofed the detefted tribe lived in hordes towards the I Recotis, and on the fpot where Alexandria was af teswardfirfounded neighbourhood of the little city of Hercules, which 
we take to be Avaris; but fome of the learned look for this town in Arabia Petrea, towards a place where many Egyptian monuments have been difcovered*. We do not include the Babylonian fettlement below Memphis, becaule it was not formed apparently until after the invafion of Cambyfes; and thofe, who were taken for Babylonians, feem rather to have been Perfians, who had in that place the only Pyrea ever feen in Egypt. The ancients have befides mentioned a troop of fugitive Trojans, whom the Egyptians received likewife, and placed them near the great quarries to the eaftward of the Nile; but the ftory of thefe pretended Trojans feems fabulous, and fome other race of men were meant, whofe hiftory is too obfcure to admit of elucidation.

Befides thefe ftrangers already mentioned; fome Carians and Ionians were found in Egypt, who at firft poffeffed fome lands near the Pelufian branch of the Nile, abandoned molt probably by the Calafires and Hermotybes. They were afterwards introduced to garrifon the capital, where they remained cons ftantly, until difperfed by Cambyfes. The Pharaohs

* They pretend that Avaris is the fame town as Ptolemais. Stephanus, and the Catalogue of Bifhoprics, place it in Arabia, with the name of Avara, which is called Avatha, in the Notice of the Empire, printed at Bafl in $155^{2}$, where the text is more correct than in any other. That opinion, however, is founded merely on the refemblance of the name; and a thoufand examples prove that Jofephus committed enormous faults relative to the geography of Egypt. In my idea he has confounded the Bubaftic canal with the Tanitic mouth of the Nile; and this confufion has prevented Avaris from being found in Sethron. 
had enployed that body of miliria in many expeditions; and it may be fuppofed they alfo took into pay the Phenicians who inhabited Memphis, when they undertook to form a navy. Nothing of the kind, however, was attempted previous to the reign of Pfammetichus, who, according to fome chrono. logifts; did not afcend the throne until the year fix: hundred and feventy-three before our prefent era.

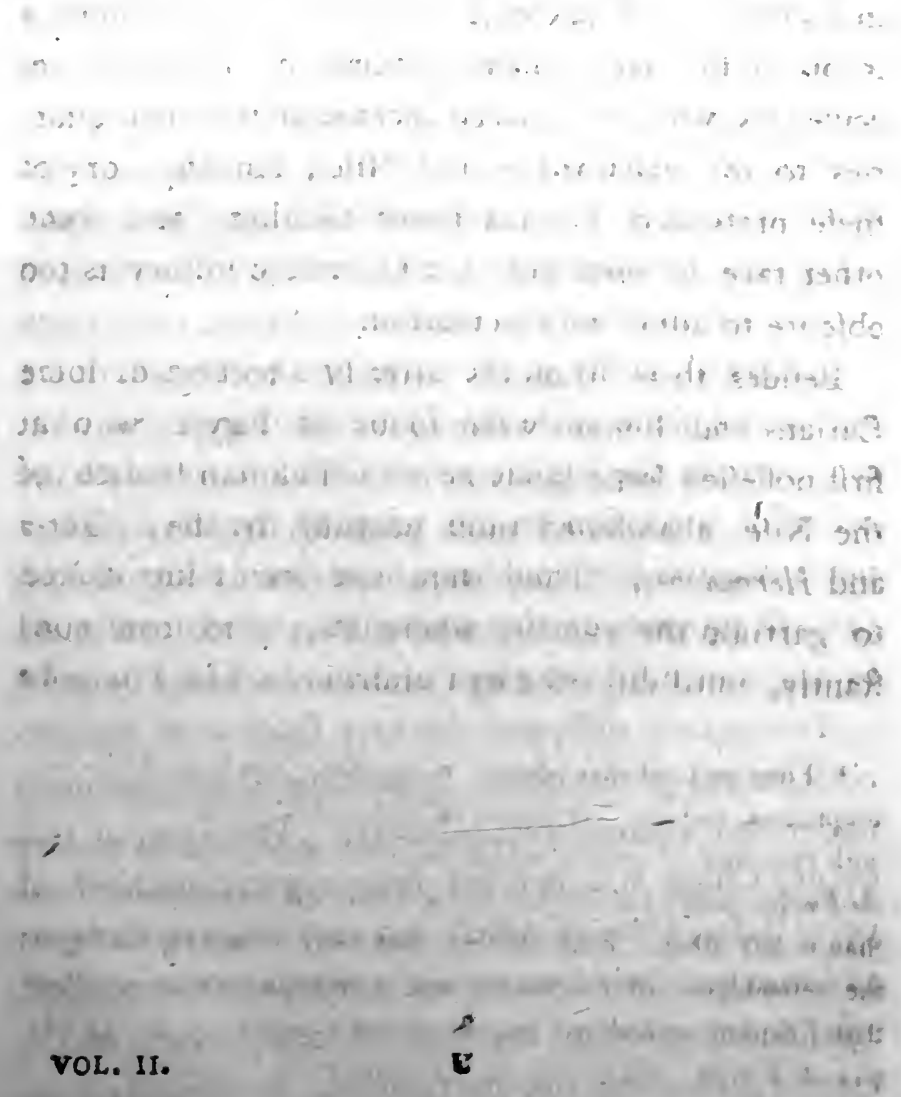


SECT. $\mathrm{X}$.

ON THE GOVERNMENT OF THE CHINESE.

A $S$ the Scythians were at all times reftlefs and A enemies to peace, the firt chiefs, chofen by the old men to conduct the hordes, led them eafily from one military expedition to another. Conftantly. at war, they had continual occafion for caciques or captains, who afterwards became independent, and tranfmitted the fovereignty to their children, or appointed fucceffors, without confulting the people. This is the reafon why the Chinefe were never feen proceeding in a body to elect an emperor, even when the imperial family in the male line became extinct; and to the fame caufe fhould be attributed the want of power in the legiflature of China to regulate the order of fucceflion in the reigning dynafty. Yet a more effential ftep could not have been taken to ftop the firft progrefs of that defpotifm, which continued to augment until the reign of Schi-chuan-di.

That prince diffipated the very thadow of the ancient feudal government, by uniting all the provinces under his immediate authority. Previous to this event, China was divided into a great number of petty ftates, fome of which had very wife regulations; and many of their laws were afterwards new-modelled, and incorporated in the general conftitution of the empire. Among the independent fovereigns, fome were found truly refpectable, who loved and practifed 
virtue: they thought no people more worthy of their protection than men of learning, who, finding it there impoffible to diftinguilh themfelves in real fcience, endeavoured to hine in works of morality, which depended lefs on acquired knowledge. Confucius in this manner obtained great reputation in the little kingdom of Lon, where he became prime minifter. If born again at the prefent day, he would not perhaps be able to attain the rank of a mandarin of the ninth clafs; for the elevation of a man becomes more the effect of chance in proportion as defpotifm increafes. If China had not been divided into fo many different ftates, it would never have become what it now is: The emperors, who fucceeded Schi-cbuan-di, entrufted the firft dignities and the government of the provinces almoft entirely to eunuchs, incapable of conceiving or executing any great project. They muft probably have fill continued in thofe employments, had not the Tartars expelled them, after having taken advantage of their treafon to invade the empire : every thing was in fuch diforcer, that formidable bands of robbers pillaged the provinces; and Pe-kin could not tefift their attacks, although defended by a garrifon of fixty thoufand men. Yet the Mnguls found the diftrefs of that country ftill greater in the thirtcenth cen. tury, when Koublai Kan employed the greateft zeal to reftore tranquillity and gocd order. He not only repaired the towns which the Chinefe had fo ill defended againft the generals of Gengis Kan, but he likewife built many others, befides Pe-kin, where he fixed the feat of empire, from political motives fuffi- 
ciently juftified by events. That prince, indeed, had a Chinefe preceptor from his earlieft years; but, hav. ing attained manhood, he faw clearly that, without the aid of foreign artifts and fcientific men, it was impoffible to cxecute any ufeful project; and the Mandhuis made exactly the fame obfervations.

China is more governed by police than by laws; and, unlefs an abfolute authority were vefted in the deputies of the fovereign, fo vaft a country could never be held under the fubjection of one perion. Yet, by means of abfolute authority, the Tartars, who could fcarcely read or write when they conquered China, have governed better there than the Chinefe themfelves, who had only their own country to regulate, while the Mandhuis have, befides, to maintain their fway in the two Tartaries.

The two chief fprings of this government are the whip and the cudgel; and neither Chinefe nor Tartar can be fecure againft this difcipline. The emperor, fays Father du Halde, fometimes orders a few bafinadoes to perfons of great rank and confequence, and afterwards treats them as if notbing bad bappened *. This is the conduct of all the defpots of Afra without exception : their fubjects may be ill ufed in a thoufand different ways; but fuch flaves can never be difhonored, becaufe that is contrary to the nature of things.

Whenever a general makes his appearance, all the foldiers fall on their knees, either in the camp or on the parade; and men of that difpofition can never be

\section{* Defcription of China, vol. ii.}


robbed of their honor. Yet the Chinefe imagine, that their form of government was modelled on paternal authority; but they could never have har. boured this idea, if their moralifts had been able to determine how far paternal authority thould extend. Thofe, who were accuitomed to defpotifm in each family, could not be furprifed to find it in the ftate; and the princes took advantage of this difpofition to introduce a fervile fubmiffioa, very different from political fubordination. Thus the fecret of government confifts chielly in promoting a falfe morality, and refraining from whatever might tend to limit the power of fathers over their children. In Perfia and Turkey, no parent can fell his fon, becaufe fuch bargains aré declared illegal; and if recourfe were had there to the Juftinian code, which is faithfully tranflated into Arabic, to fanction this abufe, the cadis would then judge according to the canonical law; for they only employ the Roman procedure in cales where the texts and gloffaries of the Koran are indecifive. In China; on the contrary, the validity of fuch contracts has never been difputed, becaufe they are known to be legal ; and the magiftrates would exert the executive power to feize a child, who had taken refuge with his uncle, after being fold by his father.

Thofe people muft be very ill informed, who maintain in Europe, that the political conflitution of China is not defpotic. They tell us in vain of judiciary tribunals being eftablifhed thére; for that is likewife the cafe in all the abfolute ftates of Afia. It can never be fuppofed that one man could decide all the contefts 
arifing in a country as extenfive as the whole of Europe.

The governors of the fmallef places have the right of pent-fe; that is to fay, they can beat all the citizens with impunity. All the tfong-tou, or viceroys, poffefs the power of life and death, without requiring to have decrees figned by the emperor, or infpected by any fuperior tribunal; and they frequently order immediate execution, without the fmalleft formality of juftice. Their inftructions point out a number of fituations when immediate death may be inflicted on criminals *; and it is precifely from having fpecified certain cafes that none are excepted. The tfong-tou can eafily convict the dead of confpiracy, revolt, and treafon, which admits of fo much variety in China. The judges do not conduct their criminal proceedings according to the manner adopted in the moft polimed countries of Europe; otherwife, the acts of procedure would be fent to Pe-kin. But they fend nothing more than the fentence, contained in three or four lines, like that of the miflionaries who were itrangled in the province of Nan-kin.

Under the Chinefe government the emperors fcarcely ever quitted their palace: when they did ga out, a kind of courrouc was made, as in Perfia, and any perfon who looked at them when paffing incursed death. All the defpots of the Falt fhut themfelves up. in the fame manner; and it would be impofitible to defcribe the evils produced by this fatal cuftom in fo

* "The emperor empowers the tforig-tou, and even the viceroy? to inflict initant death on crininals." Defcript. of China. 
many parts of Afia. The Chinefe were the only people who endeavoured to find a remedy by fending vifitors into the provinces to examine the conduct of the viceroys and tong-tou. But, when thofe govern. ors were eunuchs, it was neceflary to wink at their exactions, becaufe the emperor inherited their fortunes. This infamous cultom difgulted the Tartars; and, difdaining to be the heirs of mutilated wretches, at the expence of the people, they appointed men to govern the provinces.

The emperors of the preceding dynafty had confifcated many landed pofiefiions; and when united to their domain, they were left uncultivated. Thofe eltates became fo very extenfive, that the Tartars did not deprive the Chinefe of a fingle foot of land at the conqueft; for they found a fufficiency to make a decent eftablifhment for each of their foldiers in the different appendages. Their troops, ranged under eight banners, amounted altogether to about feventy-five or eighty thoufand men, exclufive of women, children, and Mandhuis, who came from Tartary, when the conqueft was effected, and received lands like the reft.

The name of tribunal is very improperly given, in fome relations, to certain offices at Pe kin, eftablithed for the fuperintending of the particular affairs of the prince. The pretended tribunal of buildings is merely for the infpection of the furniture of the palace, the manufactures poffeffed immediately by the emperor, and whatever works he may be defirous of having confructed: Such inftitutions are found in 
all the abfoluie fates of Afra, and they ate called cief ters, or chambers, at Confantinople and If́pahan.

'Ihe tribunal of mathematics never had that name, except in the relations of the Jefuits. It was a college under the Chinefe governnent, appointed not only to compofe almanacs, but to determine, according to certain principles of judicial altrology, the days when the fovereign could devote himfelf to difierent affairs. The precife time was alfo fupertitioufly fixed for the ceremony of his ploughing, according to the inftitution of Ven-ti. Thus we fee nearly the fame etiquette obferved at the court of China as in Perfia, where the penfioned aftrologers regulated the actions of the emperor, with this difference, that the time for him to eat with the laborers, clothed like a peafant, was determined by the magi, and not by the altrologers.

The arcient Chinefe gave the name of the $1 \mathrm{ky}$, the earth, and the four feafors, to the fix great colleges of the court. To that called autumn all criminal affairs are now addreffed; and, therefore, it hould be confidered as a real tribunal, very, different from the offices of fuperintendency.

Nothing in the whole jurifprudence of the Chinefe is more thocking, than the cultom borrowed from the Scythians, of punifhing the relations of a criminal to. the ninth degree, although their innocence was notorious. The hufband, in the firft place, is refponfible for the actions of his wife and children. At the death of the father, the eldeft fon mult anfwer for the conduct of his younger brothers : and they are all alike dragged to punifhment, and involved in the fame gif- 
grace, while their fifters are reduced to flavery with. out mercy.

On my firft arrival at Pe-kin, fays Father Amiot, that rigor appeared to me extreme; but when I obferved afterwards, continues he, that the Chinefe cannot be induced to act unlefs from fear or interelt, I began to confider this feverity as reafonable and neceflary*. But the difference is very great between fpeaking according to the principles of a defpotic go. vernment, and thore of equity and natural right, concerning which Father Amiot was very indifferent; becaufe he belonged to a fociety where obedience had too much degenerated into a blind fubmiftion.

Innocence thould in no cafe be punifhed from any motive whatever; and to allege neceffity, inftead of juftice, is renewing an ancient maxim of tyranny, which has made mankind fhudder in all the ftates of Europe. What is neceffary for the defpot may not be fo for the people. That fervile fear, which directs the actions of the Chinefe, is a confequence of their inftitutions; and who indeed could refrain from trembling in a country where innocence itfelf is not in fafety?

The emperor Ven-ti propofed to abrogate the law which punifhes a whole family for the particular fault of one of its members. On this he was told, If you wifh to reign over men, annul this inftitution; but it is neceffary to keep your fubjects in flavery:-and this fatal maxim, confequently, has been preferved unimpaired till the prefent moment.

* Chinefe Art of War. 
Ancient philofophers pretended, that, according to rigid right, the defcendants of a criminal, juftly punithed, thould not be involved in his difgrace. Plato admits only one cale as an exception to the general rule. When the great.grandfather, the grandfather, and the father of a man, fays he, have fuffered death, after being fuccellively convicted of a great crime; that perfon, he adds, fhould be confidered as infamous, and incapable of exercifing any employ in the republic; becaufe the race was evidently perverfe, when it could not be corrected by three fucceffive punifhments and the lapfe of four generations. We might be led to fpeak more ferioully of this cafe imagined by Plato, were it not fo extraordinary, that, perhaps, no example of the kind has ever occurred fince the origin of political focieties.

If it was an injuftice, according to the opinion of - philofophers, to mark thofe with infamy who were not culpable, we may conceive the barbarity or atrocity of putting them to death. When a whole Chinefe family became extinct under the hands of the executioner, the emperor confifcated their poffeffions; and the perfons of the females related to the real or fuppofed criminals were fold for his particular profit. Nearly the fame cuftom was obferved among the Scythians mentioned by Herodotus ; but all my refearches have not been able to alcertain, whether or not it had likewife been adopted by the independent fovereigns of China, who fucceeded the petty kans. 'The continual wars of the latter prevented them from improving the laws, and regulating the ftate, like the 
independent fovereigns; and Confucius, if all we have heald concerning him be true, would not, in all probability, have allowed a whole family of the kingdom of Lon to be condemned for the fault of an individual.

No nation of Afia ever exercifed a torture comparable to that of the Chinefe, who tear the thin and flefh in ftripes from the body of the accufed, until he confeffes a crime of which, perhaps, he is innocent. As different kinds of mutilations were formerly practifed in China, fome judges reprefented to the emperor $V e n-t i$, that thofe who had their legs amputated below the inflexion of the knee frequently perifhed in the operation, and even the furvivors fuffered more than death. That prince, who merited praife, had he not been filly enough to fwallow the drink of immortality, abolifhed all kinds of disfigurements by an edict, which remained in force, like the greater part iffued there, during the life of the framer. Afterwards, it became cuftomary to imprint black characters on the face, as well as to cut off the nofe; and to this the Chinefe owe their expertnefs in making artificial noles, and applying them fo as to create a perfect deception. Such ftigmas are eafily effaced entirely, although inflicted with a burning iron, or by pricking the epiderm. It is not from being in pain about their honor, that the thieves are anxious to make thefe marks difappear; but becaufe they render the practice of their villany more difficult. In other places, fays Father Trigault, garrifons are placed in towns to defend them againft foreign enemies; in China, they 
are intended to protect the towns from robbers. All travellers, however, confefs that the danger is fill greater by day than during the night. The Tartars endeavour as much as poffible to obferve a fevere difcipline; and a fingle Mandhui conducts a thoufand Chinefe with a whip, in the fame manner that a janif. fary governs as many Greeks with a cudgel.

Mr. Porter, who has beftowed fo much praife on the police of the Turks*, fhould have perceived that the fame apparent order is obvious in all the cities of defpotic Ptates; and it diminifhes in proportion to the diftance from the towns. Little fecurity can be found in the country, unlefs immediately under the protection of fome of the members of the police; who, in arbitrary ftates, are always foldiers; becaufe the prince has no other fupport.

Mr. Saimon affures us, that, according to the documents employed by him in compofing his Hiftory, not lefs than fifteen thoufand perfons are almoft confantly confined in the prifons of Canton + . But the criminals thould be diftinguifhed in this calculation from thofe who are flut up only for a few days.

When the emperor Scbi-cbuan-di united all the provinces under his immediate control, he forbade the ufe of arms among the Chinefe, and would not even allow them to poffefs an arrow or a dart. This maxim encouraged the attempts of robbers, who were fure of finding the inhabitants of the country altogether defencelefs. It occafioned alfo mańy other regulations

* Obfervations on the Religion and Laws of the Turks.

+ Prefent State of China, vol. $i$. 
relative to cafes where blood was thed; becaufe, from fuch appearances, the legiflator inferred the ufe of fome offenfive weapon. When the Chinefe fight among themfelves, each avoids carefully either tearing the clothes or piercing the fin of his antagonit. The murderer is punifhed with death; but he has always to languifh a confiderable time in prifon: for, except thofe cales where the tfong-tou and viceroys find it convenient to ad irregularly, all fentences of death mult be figned by the emperor. Some confider this formality as peculiar to China; but it is practifed in all the defpotic ftates of Afia, and principally in Perfia, as we learn from Chardin*. This cuftom is connected with the conftitution of an abfolute government, where the laws have no power without the will of the prince, who, befides, confiders his fubjects as a property; and it is contrary to the effence of fervitude, that a mafter fhould be deprived of a flave without his confent.

Religious rites have had a very great infuence, as we may well fuppofe, on the civil law of the Chinefe. The facrifices offered to the manes of their deccafed anceftors do not permit that a father hould leave his whole poffeffions to an only daughter : it is an axiom, that a woman cannot-facrifice; and, therefore, the teftator muft provide fome other perfon to perform the ceremony: Female children can never inherit any.

* “. In Perfia, the king alone can give fentence of ceath; and when the divan-bequi at the court, or the magiftrates of the provinces, find a man meriting death, information is given to the king, who decides the fate of the criminal.". Defcription of the Perfian Governneit, chap. xvii. 
thing when they have brothers; for the law divides all property equally among the males, charging them with nothing more than the maintenance of their finters until they marry; and then no dowry is ever paid. Women are particularly ill treated in China by the legiflator, who has taken lefs pains to provide for their fubfiftence than to infure their flavery.

Different kinds of fervitude are feen among the Chinefe, exclufive of what refults from polygamy. As the Tartars were the immediate flaves of their kan, previous to the conquelt of China, they continue exactly in the fame ftate at prefent. This does not proceed, as might be imagined, from any obligations impofed upon them by the idea of their holding lands through the liberality of the prince. They can fell fuch poffeffions to one another, and no longer retain any right to the alienated lands, unlefs the transfer has been made to the Chinefe, who are obliged, on receiving back the purchafe-money, to make reftitution of the landed property, which would otherwife be gradually withdrawn entirely from the conquerors. The conduct of the Tartars in China is altogether extraordinary : they have effected, through prudence, what the greateft politicians would fcarcely have dared to attempt by artifice and cunning. When Alexander forced the Macedonians to affume the garb of the Perfians, he proceeded ignorantly, but not fo abfurdly as the Moguls, who preferved their. own drefs, and allowed that of the conquered to remain alfo. Thus one Tartar was known among a thoufand Chinefe. The Mandhuis alone acted properly. 
Some are flaves in China from their birth; while others, who were originally free, have been fold either with their own confent, or by force; and their defcendants remain in bondage. Liberty is fo lightly treated, that a man can fell himfelf there at the prefent day. The Chinefe are ignorant of that fpecies of flavery known in Greece and Egypt, where one whole nation is condemned to ferve another; and which may be called lielotifm. Yet this fate might have attended the Moguls, had they been fubjugated inftead of being expelled; but, from caufes difficult to be explained, they are agdin very powerful in China, and they increafe daily, as well as the Mahometans. The latter have among them a fpecies of fiavery lefs Mhocking to natural right than ail others: they rear fome of the children expofed on dunghills by the Chinefe, and fubject them, when grown up, to a very eafy yoke.

Confifcation occafions numberlefs evils in China. It is however little known among the peafints, who are as remarkable for their virtues, as the populace of the towns are for their vices. They cannot be reproached either with bad faith, roguery, infanticide, or debauchery; for nothing equals their difcretion, fobriety, and laborioufners. But they are crufhed by continual ftatute-work, which is exacted with great rigor in China, as well as throughout the whole of Afia.

An edict of the emperor Sucn-ti exempts for fome time from public works thofe who have loft their father or mother; for thefe unfortunate people, fays 
he, fhould be allowed to reimburfe themfelves for the expences of this burial. This was indeed a trifling remedy for a very great evil. As the greater part of the Chinefe peafants have neither oxen nor horles, they cultivate with their hands alone the portions of land they rent from the great proprietors *. To labor for the fovereign is ruinous to thole people for two reafons: they lofe, as the emperor Suen-ti obferves, a great deal of precious time, and their ftrength is exhaufted by being forced to fupply the place of cattle. I obferved, fays Nieuhof, when paffing from Canton to Pe-kin, that the Chinefe peafants were frequently forced by fripes to draw the veffel which conveyed the Dutch ambaffador; although he begged the conduct. ors to hlow more moderation. This is the fituation. of thofe people, who form the moft refpectable part of the empire; and it is a melancholy circumftance that their habitations, when far difant from towns, cannot be protected againft thieves and vagabonds.

On advancing towards the centre of the provinces, fewer appearances of labor are feen, and the villages, dininith in number. Thus, not nearly one-half of, the foil in the whole empire is cultivated; particularly if we include the prodigious cantons of thofe favages called Mia-ofe. Yet agriculture cannot be confidered as brought to great perfection in any country, until. the arable are in proportion to all the barren lands as fifty to three; and we are told that this has been. effected in England.

- Eckerberg. Bericht von der ChivefiRen Landwirthfchaft. 
All the provinces of China muft not be judged by thole of Che-kan and Nan-kin, the foil of which is confidered as formerly belonging to the fea, or an inundation of the Yellow River. The chief mouth of that river is faid to have been anciently in the gulph of Pe-tcheli, five degrees more towards the north than at this day. Father Gaubil, in his Hiftory of the Moguls, fpeaks very fully of this change, without being willing to admit that the emperor $T u$ could never have conducted the Yellow River like a brook, and that too at a period two thoufand two hundred years before our era. But, in fact, the whole account given in the Cbou-King is grofsly fabulous. When we confider the map, it would feem indeed that the extreme irregularity in the courfe of that river had proceeded from dikes conftructed for the purpofe. If the Chinefe do not take more efficacious meafures than they have hitherto adopted, the Yellow River muft again occafion many embarrafiments, for its windings are too confiderable; and, if it really fell originally into the gulph of $P$ c-tcheli, it may well be expected to refume that direction.

As the Chinefe have a frong propenfity, or rather an ardent paffion, for commerce, the emperor $\dot{V}$ en-t $t$ endeavoured to give fome confequence to the profeffion of hufbandmen, that they might be preferved from that fpirit of traffic and roguery, which, like a growing contagion, infected the nation ever fince the government became defpotic under Scbi-cbuan-di. But the ceremony of the emperar tilling the earth, as many yoz. II. 
monarchs of India had done before, could not com: penfate for arbitrary impofition and continual ftatute* labors Let agriculture be freed from the hackles of tyranny; and then, inftead of requiring recom. pences or honors, its own force will be fufficient to enfure an ample reward.

What has moit contributed to retain the Chinefe peafants in the country, is the confcioufnefs that their vexations are not equal to thofe of the merchants but the latter always fteer againft the fream, inftead of being difcouraged by obftacles. They refemble the Jews, who inhabit the different ftates of Afia : their continual grievances goad them on; and they purfue traffic, becaufe it enables them to purchafe protection at court. The great injuftice they experience is in fome meafure repaired by the opportunities they are allowed of making illicit gain; and, to explain this, we hall quote a paffage of the Journal of $\mathrm{Mr}$ de Lange, agent at Pe-kin for the court of Peterfbourg. The gentry in China, fays he, defraud the mercbants, and take away their wares under every kind of pretext,. without their ever being able to obtain payment. On that account, the traders and others who exercife lucrative profeffions at Pe-kin, are accuftamed to chufe protectors among the princes of the blood and other great lords or minifers of the court, to zulsom they pay annually a certain proportion of their gain. By this expedient they are infured againft the extortions of mandarins, and cven of private foldiers. Witl out powerful protection a merchant is a ruined man in China, and particularly at Pe-kin wetherts 
cobere every perfon thinks be has an inconteftable right to form pretenfions on thofe wolso live by traffic. If any man. is rafh enough to require an equitable reparation by the way of public jufice, be falls from bad to worfe. The mandarins, after baving drazun from bin as mucb money as polfible, do not fail indeed to order the effects taken anjuffly to be brought to the college; but be muft be fill more knowing to bave them taken thence.

From the combination of thefe caufes, and many others, it refults, that the number of merchants even moderately rich is not very great, confidering the quantity of thops and the multitude of pedlars who crowd together in the principal towns of the empire, or frequent the fairs. The exterior commerce is not fuppofed to amount to more annually than five million ounces of filver; and the ounce of that metal at Pe-kin is now equal to about fix fhillings and threepence.

Several writers have fpoken of the revenues of the emperor of China, but in a manner fo very vague, that nothing fatisfactory can be deduced from it. Mr. Salmon does not believe that the whole imperial income amounts to more annually than twenty-two millions of pounds fterling. The real receipt in filver moft probably does not exceed two thirds of that fum; for we do not fpeak here of what is paid in kind, although it may admit of being eftimated with fome exactnefs: but no perfon can calculate the value of confifcations, which are of infinite importance to ara.ticipus princes. 
It thould be obferved, that, in all defpotic fates, the revenues of the fovereigns are much lefs than we are tempted to believe, confidering the great extent of their dominions. The fultan did not receive annually four millions of pounds fterling from all the countries in Europe, Afia, and Africa, which were under his fway before the laft war. The revenues of the great Mogul have been greatly exaggerated; for they do nor in reality exceed one hundred and eightyfive millions of ficca, or fomewhat lefs than twentythree millions fterling.

Under the Chinefe government the eunuchs had introduced fo much diforder into the finances of the empire, that it has hitherto been impoffible to clear up the chaos. The Tartars found the greater part of the provinces indebted fo largely to the treafury, that the debt could never be paid, and it was no longer required. The eunuchs dreamed of nothing but impofts, until they wanted means to levy them; and, when the people complained of a tax an falt, it was commuted for another on iron. Some of their dreadful depredations are detailed by a chinefe author, called Chi-kiai, whofe expreffions we have preferved on account of their energy.

"Under the prefent dynafty," fays he, "we hear si of nothing but impofts, duties, and prohibitions. "This is excefive. They are levied on the moun"6 tains, and on the vallies; on the rivers, and on the is feas; on falt and on iron; on wine and on tea; on is linens and on filks; on paffages and on markets 
es on brooks and on bridges: on all thefe, and on " many other things, I fee every-where the prohibi"6 tory mark*."

The emperor did not receive the thoufandth part of thefe exactions, which were farmed out by the eunuchs to men who gave them the greater part of the profits. To palliate the deficiency of the receipt, they declared the provinces indebted for great fums, although they proceeded from impofitions added to the ordinary tribute. This artifice appeared execrable to the Tartars, who had not yet, fays Father Amiot, loft their. natural probity; and they reformed the falt.works and cultom-houfes, except that of Canton; which, in Afia, is as odious as thofe of Spain and Portugyal are in Europe.

Befides all thefe, another exceflive abufe exilted until it was remedied by the emperor Can-bi. In republics and moderate governments, thofe who rent lands in order to profit by them, might be charged with the taxes; but, in defpotic fates, they muft be required from the proprietors, otherwife the tenants are liable to be haraffed both by the landlord and the fovereign. This was exactly the cafe in China at the arrival of the Tartars, who ordered that, in future, none but the real owners of eftates flould be refpon: fible for the taxes.

The greater part of the revenues of the emperor of Chisla confift in rice, wheat, raw and wrought filk; hay, fraw, tobacco, tea, and brandy. :They are,

- Collection of Imperial Edicts and Remonftrances, \&c. tranf; fred from the Chinefe by Father Hervieu. 
therefore, under the neceflity of paying their officers in the fame way; and, as thofe ariicles cannot be fold without lofs, numberlefs mifdemeanours are the confequence. Money is always very rare wherever the fovereigns do not receive impolts in fpecie. This fcarcity irritates avarice on the one hand, while, on the other, llavery foments luxury. People wilh to appear great in proportion as their real confequence is diminifhed; and therefore, when almort annihilated by arbitrary power, the Chinefe cannot difpenfe with embroidered clothes:

In a country of flavery a poll-tax is fo natural, that the Chinefe, who have murmured againft all others, have fupported that impon patiently. But the extracts of their regifters of capitation, fuch as they have appeared in Europe, are altogether falfe, as we have proved in the fecond article of this work. We thall not repeat here what has been faid concerning the population of that country; but it certainly does not amount to eighty millions of fouls. The Tartars found only eleven million fifty-two thoufand eight hundred and twelve families, which multiplied by five, would not make fixty millions. Confidering the prodigious extent of China, it is much more thinly inhabited than Germany ; and it would be fill lefs populous but for the favorable climate of the fouthern ptovinees, which, according to the miffion: aries, are far better peopled than thofe of the north.

As the political infitutions of that empire have not the fmalleft analogy with the government of ancient Egypt, neither facerdotal nor military families were 
ON THE EGYPTIANS AND CHINESE.

ever feen there. The Chinefe foldiers, contrary to the regulations of the Calafires and Hermotybes, carry on commerce, exercife trades, and cultivate lands, as was cuftomary at all times, even before portions twere affigned to the eight banners of the Mandhuis: If we are to believe Father Amiot, the pay of each foot foldier cofts the emperor Kicn-long twenty-five fhillings every month, of which one-half is paid in money, and the other in rice; while that of a horfeman is thirty-feven fhillings and fixpence, paid in the fame manner with the former *.

In general, the maintenance of troops cofts more in defpotic ftates than eliewhere; but it is not pro. bable that all the Chinefe forces, which may be divided into five claffes, are on the fame footing. The firt comprehends the cavalry : they have no fire-arms of any kind; becaufe the Tartars, who perhaps underftand this part of tactics better than any other, are convinced that bows are much preferable to mufketoons; and they continue, like all the Parthians and Scythians, to thoot arrows when in full gallop. The fecond divifion is compofed of cannoniers and arquebufiers : the third of pike-men : the fourth of infantry, who ufe bows : and, laft of all, thofe who are armed with fwords and bucklers.

The exercife of all thefe troops; fo very differently armed, refembles a theatrical play in the colored prints at the end of the work entitled Art Militaire des Chinois. The moft ludicrous of all their farces is

Cbinefe Art of War, p. 30:

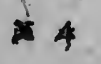


performed by the infantry, who conceal themeltres. behind bucklers, which are placed in fuch a mannet as to refemble a flower, called by the Chinefe me -boa; and, for this purpofe, five men are obliged to lie upon each other horizontally Theie buffoons afterwards counterfeit thole Scythian dragons, called $l u$, or loung, with which their colors are covered; and then they become tygers, fpringing from under their hields as from a thicket to feize their prey. But their grand. mancuvre is to imitate the projection of the moon, which ferves as a buckler to the mountains, or, as the Chinefe. exprefs themfelves, yen yue pai-chan tcben*. In a general evolution, where the five bodies of militia are employed, a reprefentation is given of the four corners of the earth, which they believe to be fquare, and of the rotundity of the $\mathrm{ky}$. This is practifed by mixing the cavalry with the infantry, in fuch a manne: that it is almoft impofible to form any diftinct idea of it. Father Amiot himfelf feems to have been very ignorant of the matter; for, to all appearance, the prints fent by him from Pe-kin to Paris, reprefent only imaginary manœuvres, or military anufements; and, at all events, they did not deferve to be engraved.

We have not been able to afcertain how many troops the Tartars continue to keep on foot fince the conquelt; but they cannot be very numerous, if we

- Chinefe. Art of War, p. 348.-From the dragons on the Scythian ftandards, feems to have been derived the word Dragoon', fignifying a foldier who ferves either on foot or on horfe; and Alexander is faid to have àdopted that term aftet the Perfians. 
believe the emperor Kien-long, who pretended that one Mandhui could eafily fubdue ten men : let it be underftood, however, that they muft be Chinefe, particularly when concealed under their fhields to imitate the flower mei-boa, or the projection of the moons,

The emperor Kien-long could not be ignorant, that the conqueft of China by his anceftors was owing in a great meafure to the almoft incredible diforder into which the eunuchs bad plunged that country, as well as to the wretched ftate of the Chinefe militia. Father 'Trigault, who faw thofe troops previous to the entry of the Tartars into Pe-kin, declares, that fuch a col lection of vile wretches had not been feen for many ages in Afia. They confifted in great part of flaves belonging to the emperor as well as to private people, and all equally capable of the moft infamous functionss They, or their fathers, had been fold and reduced into flavery for different crimes; and, although called foldiers, they were nothing more than banditti *.

The magiftrates of China are divided into nine or: ders; and this inftitution feems to be founded en. tirely on the fuperfitious infatuation of the Chinefe. for the number nirse. Some of our authors fpeak with admiration of thofe prodigious examinations un dergone by candidates, previous to their being adi mitted to the office of mandarin. The origin of this

- Nulla gens aquè vilis atque iners eft quam militaris apud Sisas... Maxima pars regia funt municipia vel propriis, vel majorum fuorum fceleribus perpetuam fervicntes fervitutem. Iidem quo tempare a bellicis exercitationilus vacant infina quaque officia, bajulurum, mulionum, et

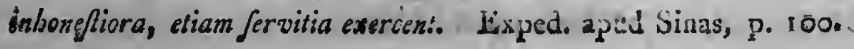


cuftom is eafily conceived, when we reflect upon the nature of the Chinefe characters. In Europe, it is eafy to be convinced in half an hour whether or not a perfon can read and write. But in China, on the contrary, this requires a long fcrutiny; for a man of letters, who thould have made himfelf acquainted with ten thoufand characters, dnes not perhaps know more than three thoufand. Many proofs are therefore neceffary to determine the real extent of his learning, and how far he can compofe in writing, which, if done with perfpicuity, is fo very difficult, that few of the literati are capable of effecting it, as we learn from the miffionaries. The loweft clafs of merchants at Canton have generally a fmall provifion of characters by heart, fufficient for their mercantile affairs; and, beyond that, they neither know how to read nor write. Thus it became neceffary to inftitute thofe long examinations in China, which are common in all the other defpotic itates of Afra. In Turkey, the cadis and imans are not admitted, with. out having undergone fome proofs; but money can render the Turks and Chinefe much more learned than all their ftudies. It is publifhed even on the theatres of China, fays Mr. Torrens, that the places under government are all venal, as well as the office of mandarin *. Befides, the want of public fchools is a great obftacle to the elevation of thofe who are born without fome fortune, and whofe parents have not the means of paying a private tutor.

* Reife nach China 
That clafs of men; who require moft to be frietly examined in China, are fubject to no fuch formality. We fpeak here of the medical profeffion, which is open to every perfon without any obligation to ftudy the art of healing. The firft relations, fays Morhoff, publifhed by the miffionaries in Europe, gave high ideas of the Chinefe phyficians; but when the work of Cleyer appeared, continues he, the enthufiafm ceafed, and their admirers have been covered with ridicule *. Not one Chinefe has any knowledge ei. ther of the internal parts or anatomy of the human bndy. The work of Dionis has indeed been publifhed in the Tartar language; but all the miffionaries together could not have tranflated it into Chinefe; and that book, fo little efteemed in' Europe, is certainly not fufficient to form an anatomift. All the real fciences have been neglected beyond belief among the Chinefe; and their conduct towards phyficians was entirely oppofite to that of the Egyptians, who were accufed in this point of extreme feverity. Some Greeks pretend, that they inflicted death on thofe who fwerved from the rules prefcribed in the Hermetic books for the treatment of patients. We have already obferved, that, in epidemical diforders proceeding always from the fame caufe, and accompanied invariably with fimilar fymptoms, the Egyptians were

- Cleyeris nuper nobis revelavit medica Cbinenfium myferia, qu ubi in lucem protradia funt, rifum potius, quam applaufum merentur; à merito pudorem illis incutiunt, qui Europe medicincs :objicere non funt veriti perfectionem medicine Chinenfis. Morh. Polihilt. lib. i. 
right in adopting fixed medical rules. Every fick perfon would certainly prefer being arbitrarily treated by a fkilful doctor to all formularies whatever: but, when practitioners are ignorant, it is fome comfort to have their prefcriptions confined to a particular form. We fpeak however of the Egyptian regulations on this point, without being able to afcertain any thing; becaufe they are not fufficiently known. It is believed, from paffages in Ifocrates and fome other ancient authors, that the phyficians in Egypt were not allowed to employ any medicines more violent than thofe contained in their pharmacopeia. But the punimment of death was moft probably confined to oculifts, dentifts, and furgeons, who had taken upon themfelves to adminifter drugs improperly, beyond the bounds of their art. The Egyptians had very fevere laws againt murder; and the crime appeared to them nearly the fame, whether a poor wretch was affaffnated in his bed or on the high-way.

No lawyers are found among thofe men called the literati of China; becaufe the parties have to appear before the judge, as in Turkey, and throughout the whole of the Eaft. Some have pretended that their knowledge in the practice of the civil law was very: extenfive: but, in fact, they are totally ignorant of the matter, as may be demonftrated even from the teftimony of the miffionaries, who have moft exalted the qualifications of the Afratics. No appeal can be made there from any fentence whatever. This is no. lefs oppofite to the principles of civil law, than conformable to the in?titutions of a defpotie ftate. 
4. However the law may reftrain a Chinefe magi* "k6 Atrate in criminal cafes," fays Father du Halde, "6 he is almoft abfolute in civil matters. All contefts " relative to the property of private perfons are " judged by the great officers of the provinces with" out any appeal; although, in affairs of confe. "quence, complaints may be lodged before the fove"reign court at Pe-kin *."

People are allowed likewife to complain even at Tunis and Morocco; but no appeals are admitted there in civil procedures, which are more fubject to injuftice than all others. It is feldom that a judge can be led to act partially in criminal caufes, which tend to diturb public tranquillity; but he may be corrupted in different modes, when an action concerns only private interefts. The prohibition of ap* peals is the more unpardonable when the rules of juxilprudence are neglected in the procedures; and, to prove that this is the cafe in China, we have only to extract a paffage from the work of Father du Halde. "Although the governor of the province," fays he, "has under him the four great officers, and each "c mandarin is provided always with one or fometimes "t two affeffors; yet the affairs are not ordinarily de* "6 cided by a plurality of votes. When the parties 's are brought before the tribunal, or yamen, of any 6s magiftrate of whaiever rank, after fome few forma. adifties obferved by the regifters, bailiffs, and other fuch co people, he pronnunces according to his own willy W and formetimes orders the perfon, who has loft his

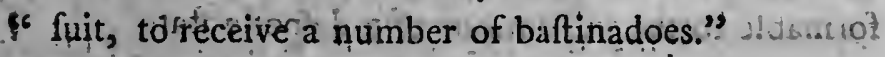

* Defcription of China, vol, i. 
This is exactly the mcthod of the Turks, without the fmalleft difference. More caufes are judged and decided there in an hour, than the tribunal of thirty at Thebes could have inveftigated in a month. The deteftable cuftom of pronouncing without collecting votes, and of beating the pleaders afterwards, could never have been introduced or maintained but in ftates completely defpotic. Slaves are governed by the cudgel, and men by the law.

The pride of the Chinefe proceeds from their ignorance and their fervitude : for other nations of Afia, not more free, are no lefs puffed up with ideas of their own confequence. Their adherence to ancient rites is the effect of education; and their attachment to their native country is produced by the worfhip rendered to anceftors, near whofe tombs it is neceffary to remain. Patriotilm cannot exift in an empire fo extenfive as China. When fome people of former times poffeffed no other domains than a town and a few fields round the ramparts, the love of their country was extreme; becaufe they knew each other, and their common poffeffions. But a Chinefe, born at Pe-kin, does not underftand the language of a native of Cánton'; and how can fuch people confider themêt felves as countrymen? This diverfity of dialects can be ufeful to the defpot alone, by preventing the provinces from confpiring together fuddenly ; and China, for the fame reafon, has no polts for conveying private letters. Correfpondence in that way would be too alarming for the government; and it appears by different relations, that the emperor is frequently under 
the neceffity of employing foldiers to efcort his own couriers.

Thus China difcovers nothing in point of legifla. tion more wonderful thar the other empires of the Eaft. They fubfift, becaufe it would be furprifing indeed that a ufurper fhould not be found whenever a fovereign is wanting. Perfia has been an empire from the days of Cyrus to thole of Kerim-kan; and nothing but fome phyfical revolution, not to be expected, can prevent it from continuing fuch for many ages longer.

No fooner is one Chinefe dynafty hurled from the throne, than fome perfon prefents himfelf for the fucceffion. The people have not time to reflect: The provinces are ignorant of the event, though the man is already in polfeffion of the fovereign powers. Frequently the fubjects neither know who the perfon is, nor whence he came; and they learn all thofe circumftances only when his power is eftablifhed. China has had a fhoemaker at one time, and the cook of a convent at another, for its emperors; and no country, except India, during the dynalty of the Moguls, ever faw fo many fovereigns dethroned, naughtered, and poifoned, without reckoning the one who hung himfelf at the arrival of the Tartars.

Many dreadful misfortunes would have been avoid: ed in that country, had the order of fucceffion been tegulated among the defcendants of the emperor: but the thing is abfolutely impoffible, becaufe the fovereign there will not admit of any curb. The Mandhuis have no better political inftitutions on that head than the Cininefe. 'i he emperor Can-bi amufed 
bimfelf with the fate of his children. When poi: foned, the Chinefe Gazette announced them dead of an apoplexy; and by the intrigues of the feraglio, bitherto not fully revealed, $r_{0}$ ing tcheng came to the throne; although all the aftrologers of the empire would have laid wagers to the contrary. The hiftory of defpotic empires can never be written in a man. ner either inftructive or fatisfactory. Great events are there decided by caufes, which could not be re. lated without hame, even when well attefted. The Chinefe are foolih enough to believe that anciently the wife of one of the emperors was employed in writing the tranfactions of the feraglio, to communicate them to the annalifts of the empire. No perfon, however, has fcen a fingle leaf of thofe me. moirs, which would have merited no more belief than the Court Gazettes. The emperors, fays Father Amiot, frequently receive compliments from the great colleges on the victories which thefe gazettes znnounce; while the flattered princes know beyond doubt that their troops have been entirely defeated. Of this however the people and. the great colleges are ignorant; for both officers and foldiers are forbidden, under pain of death, to give information of . what paffes. The general lies, and the army is filent.

THis work was undertaken to fhow that no twa nations ever refembled each other lefs than the Egyp. tians and Chineie ; and as that object is now, in my opinion; fully accomplithed, it would be fuperfluous to proceed any further in our refearches. 




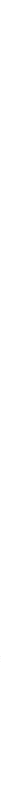

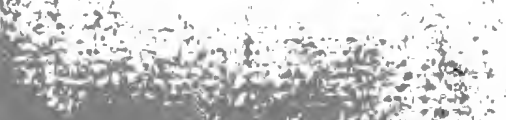

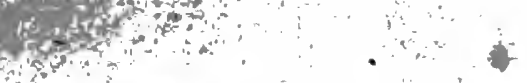
Din $2 \pi x^{2}$

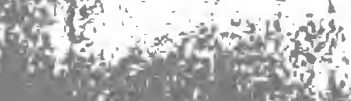

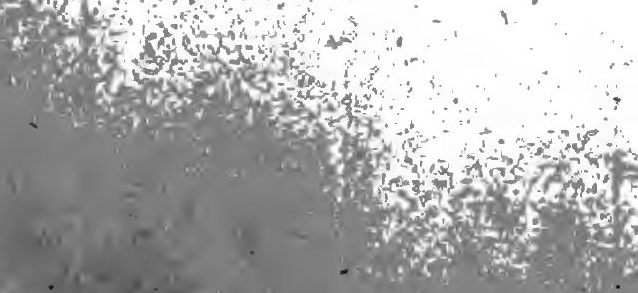






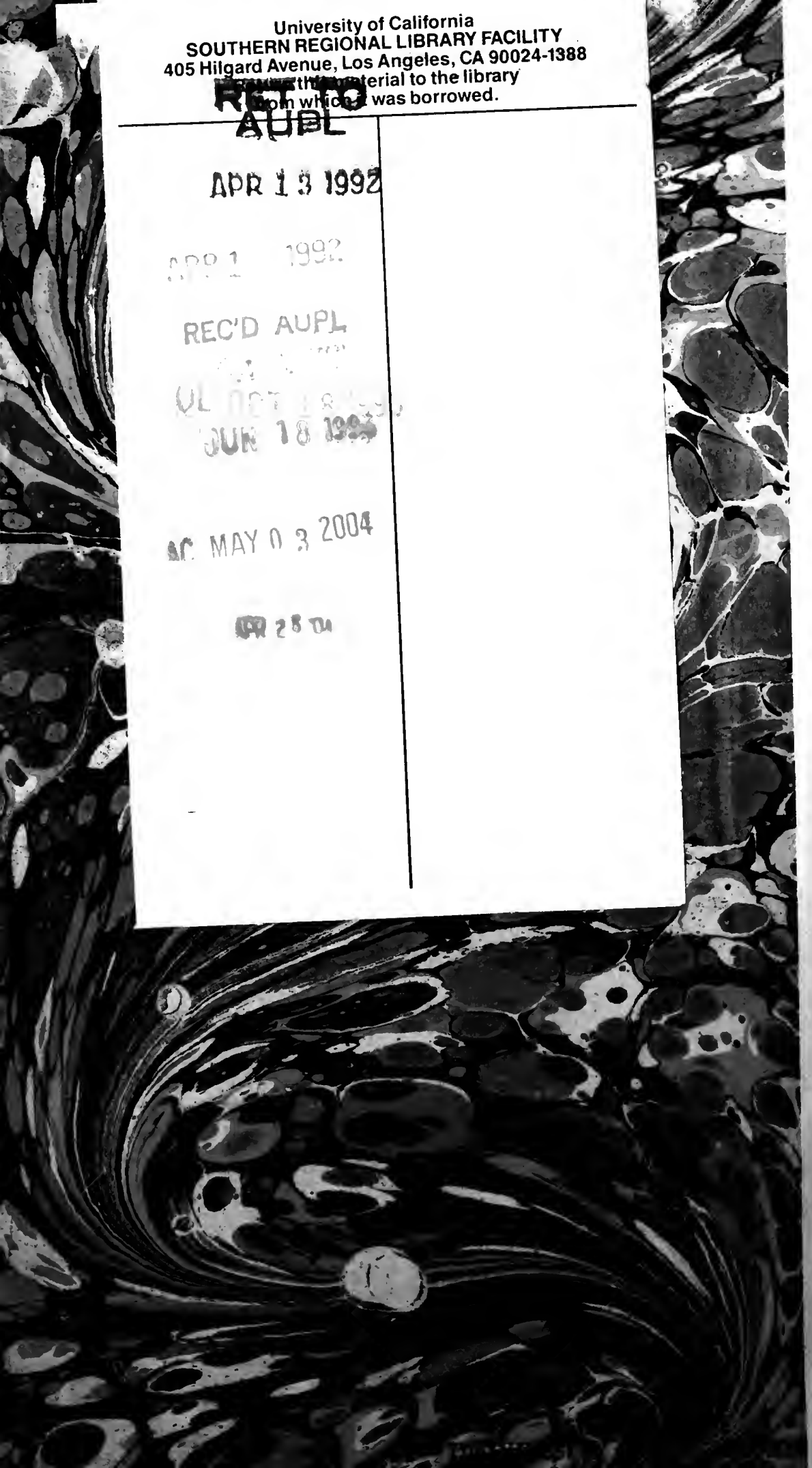




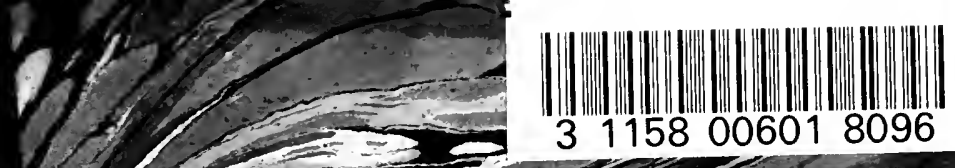

t.

. II

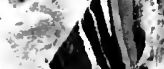

M. 11

$\left.7 r^{2}\right)$ of

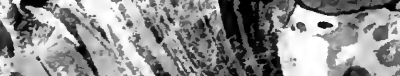

(a) $+1+2$

and Nol

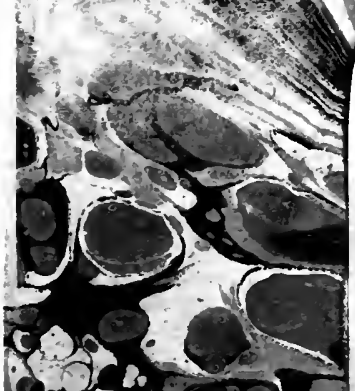

is

ind 0

$1)^{2}\left(\frac{1}{2}\right.$

10
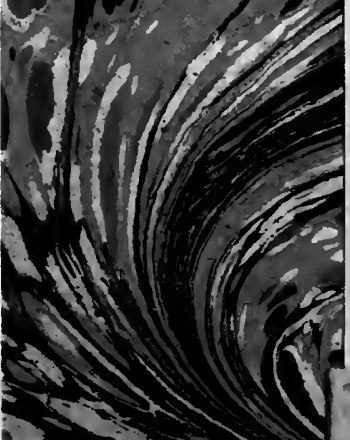

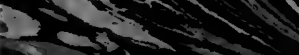

\%

Dr $-2+2$

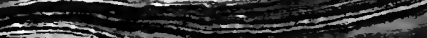
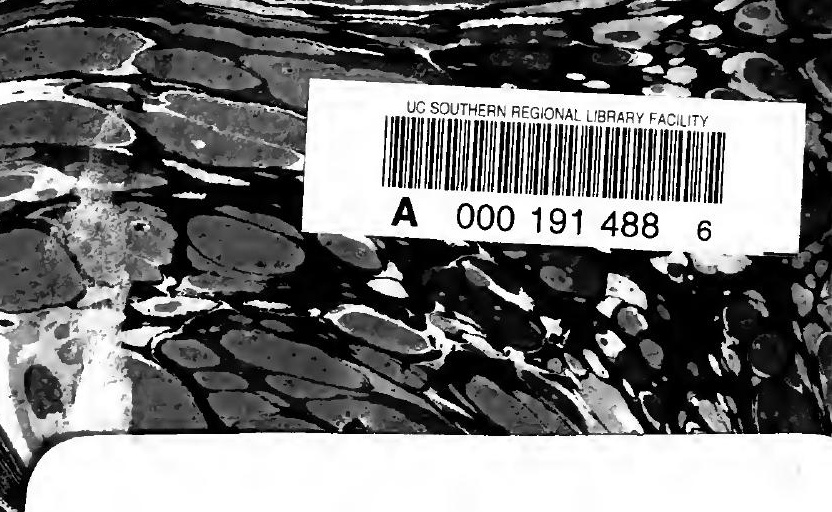


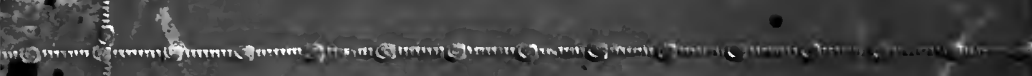
4<smiles>[13CH][13CH]</smiles> 